Final Report

FHWA/IN/JTRP-2000/28

\title{
DEVELOPMENT OF A PROCEDURE TO IDENTIFY AGGREGATES FOR BITUMINOUS SURFACES IN INDIANA
}

\author{
Terry R. West \\ Professor \\ Principal Investigator \\ and \\ Kyu H. Cho \\ Research Assistant \\ Department of Earth and Atmospheric Sciences \\ Purdue University \\ Joint Transportation Research Program \\ Project No. C-36-6RR \\ File No. 2-4-44 \\ SPR-2206 \\ Prepared in cooperation with the \\ Indiana Department of Transportation and \\ the U.S. Department of Transportation \\ Federal Highway Administration
}

The contents of this report reflect the views of the authors, who are responsible for the facts and the accuracy of the data herein. The contents do not necessarily reflect the official views or policies of the Indiana Department of Transportation or the Federal Highway Administration at the time of publication. This report does not constitute a standard, specification or regulation.

Purdue University

West Lafayette, Indiana

September 2001 
TECHNICAL, REPOR'T STANDARD TITLE PAGE

\begin{tabular}{|c|c|c|}
\hline $\begin{array}{l}\text { 1. Report No, } \\
\text { FHWA/IN/JTRP-2000/28 }\end{array}$ & 2. Government Accession No. & 3. Reciptent's Calalog No. \\
\hline \multirow{2}{*}{\multicolumn{2}{|c|}{$\begin{array}{l}\text { 4. Title and Subtille } \\
\text { Development of a Procedure to Identify Aggregate for Bituminous Surfaces in Indiana }\end{array}$}} & $\begin{array}{l}\text { 5. Report Date } \\
\text { September } 2001\end{array}$ \\
\hline & & 6. Performing Organization Code \\
\hline \multicolumn{2}{|l|}{$\begin{array}{l}\text { 7. Author(s) } \\
\text { Terry R. West and Kyu H. Cho }\end{array}$} & $\begin{array}{l}\text { 8. Performing Organizalion Report No. } \\
\text { FHWA/IN/JTRP-2000/28 }\end{array}$ \\
\hline \multirow{2}{*}{\multicolumn{2}{|c|}{$\begin{array}{l}\text { 9. Performing Organization Name and Address } \\
\text { Joint Transportation Research Program } \\
\text { 1284 Civil Engineering Building } \\
\text { Purdue University } \\
\text { West Lafayette, Indiana } 47907-1284\end{array}$}} & 10. Work Unit No. \\
\hline & & $\begin{array}{l}\text { 11. Contract or Grant No. } \\
\text { SPR-2206 }\end{array}$ \\
\hline \multirow{2}{*}{\multicolumn{2}{|c|}{$\begin{array}{l}\text { 12. Sponsoring Agency Name and Address } \\
\text { Indiana Department of Transportation } \\
\text { State Office Building } \\
100 \text { North Senate Avenue } \\
\text { Indianabolis. IN } 46204\end{array}$}} & $\begin{array}{l}\text { 13. Type of Report and Perind Covered } \\
\text { Final Report }\end{array}$ \\
\hline & & 14. Sponsoring Agency Code \\
\hline \multicolumn{3}{|c|}{$\begin{array}{l}\text { 15. Supplementary Notes } \\
\text { Prepared in cooperation with the Indiana Department of Transportation and Federal Highway Administration. }\end{array}$} \\
\hline
\end{tabular}

\section{Abstract}

Adequate friction resistance is needed to prevent pavement slipperiness allowing vehicles to stop in a reasonable distance. For stone mastic asphalt surfaces, friction resistance is mainly a function of the interaction between the aggregates exposed at the road surface and vehicle tires. Aggregate performance is reduced with time by wear and polishing as a consequence of vehicular traffic. In this research a method to investigate performance based on physical, chemical and petrographic factors has been evaluated. The objective was to develop a laboratory method to test Indiana dolomite, limestone, sandstone, and gravel aggregates to predict friction resistance in the field and determine causes for the range of values among these aggregates. Assessment of gravel sources was based on individual rock types and their proportions comprising the gravel. Initial friction Values (IFV) and Polished Values (PV) were determined in the laboratory with the British Wheel and Pendulum test and field values obtained from the towed friction trailer. For two laboratories involved a significant difference in IFV and PV was obtained so that further verification is required. Correlations between parameters were established which provide predictions of friction resistance based on laboratory specimens. A database of physical and chemical properties should be collected on aggregates used or considered for bituminous wearing courses. This includes the testing required for Class A aggregates plus elemental $\mathrm{Mg}$ and elemental Ca content.

\begin{tabular}{|l|l|l|l|}
\hline $\begin{array}{l}\text { 17. Key Words } \\
\text { bituminous surfaces, friction resistance, dolomite, } \\
\text { limestone. }\end{array}$ & $\begin{array}{l}\text { 18. Distribution Statement } \\
\text { No restrictions. This document is available to the public through the } \\
\text { National Technical Information Service, Springfield, VA 22161 }\end{array}$ \\
\hline $\begin{array}{l}\text { 19. Security Classif. (of this report) } \\
\text { Unclassified }\end{array}$ & $\begin{array}{r}\text { 20. Security Classif. (of this page) } \\
\text { Unclassified }\end{array}$ & $\begin{array}{l}\text { 21. No. of Pages } \\
115\end{array}$ & 22. Price \\
\hline
\end{tabular}




\section{TECHNICAL Summary}

\section{Development of a Procedure to Identify Aggregates for Bituminous Surfaces in Indiana}

\section{Introduction}

Adequate friction resistance is needed to prevent pavement slipperiness allowing vehicles to stop in a reasonable distance. For stone mastic asphalt surfaces, friction resistance is mainly a function of the interaction between the aggregates exposed at the road surface and vehicle tires. Aggregate performance is reduced with time by wear and polishing as a consequence of vehicular traffic. In this research a method to investigate performance based on physical, chemical and petrographic factors has been evaluated. The objective was to develop a laboratory method to test Indiana dolomite, limestone, sandstone, and gravel aggregates to predict friction resistance in the field and determine causes for the range of values among these aggregates. Assessment of gravel sources

\section{Findings}

This study was a continuation of previous work by Bruner, Choi and West, 1995, FHWA/IN/JHRP $95 / 11$, which focused primarily on dolomite aggregates (19 sources). In the current study, 21 limestone sources, three sandstones and six gravel sources were added. Data from both studies were evaluated to provide an overall conclusion. Frictional performance is determined by polishing aggregate coupons with the British Wheel machine and measuring friction values with the British Pendulum tester. This provides the IFV (initial friction value), PV (polished value or BPN at 10 hours) and the difference between IFV and PV, WI, wear index. was based on individual rock types and their proportions comprising the gravel. Initial friction Values (IFV) and Polished Values (PV) were determined in the laboratory with the British Wheel and Pendulum test and field values obtained from the towed friction trailer. For two laboratories involved a significant difference in IFV and PV was obtained so that further verification is required. Correlations between parameters were established which provide predictions of friction resistance based on laboratory specimens. A data base of physical and chemical properties should be collected on aggregates used or considered for bituminous wearing courses. This includes the testing required for Class A aggregates plus elemental $\mathrm{Mg}$ and elemental $\mathrm{Ca}$ content.

Following aggregate collection, megascopic and microscopic evaluation of the aggregate samples was accomplished. Twentyfour additional rock thin sections were examined to extend those from the first study. Laboratory tests included acid insoluble residue (ASTM, D3042), size distribution of acid insoluble residue, elemental Mg content (ASTM, C602), Los Angeles abrasion (ASTM, C131), sulfate soundness (ASTM, C88), freeze-thaw loss in water and in brine solution (AASHTO, T103, Procedure A), absorption and specific gravity (ASTM, C127). These were conducted at INDOT, Division of Materials and Tests, and at Purdue University. 
Aggregate coupons of limestones, sandstones and gravels were made for the British Wheel test and British Pendulum test (ASTM, D3319, E303). The coarest portion of the No. 11 INDOT gradation, $12.5 \mathrm{~mm}$ to $9.5 \mathrm{~mm}$ in size, was used. To construct the coupons, aggregates were embedded in epoxy resin and a hardener component added. The epoxy was different from that used in the 1995 study (Bruner, Choi and West). Coupons were polished using the British Wheel machine and measured with the British Pendulum tester after zero hours (IFV), 1 hour, 3 hours, 6 hours and 10 hours (Polished value, PV or $\mathrm{BPN}_{10}$ ). These data were added to the existing information from the previous dolomite study (Bruner, Choi and West, 1995, FHWA/IN/JHRP 95/11).

Finally, analysis of all data from the current and the 1995 study were combined and a statistical evaluation performed. Results were compared to those from other states. Based on this, PV of dolomites and limestones required for bituminous surface courses can be recommended. Results can be used to develop specifications to evaluate additional sources for medium and high vehicular traffic pavements having bituminous overlays in Indiana.

Gravels consisted primarily of limestones and dolomites. The weighted PV ranged from 22.6 to 26.3 and PV correlates best with freeze-thaw loss. Other important factors are absorption, percent of crushed gravel pieces and percent of metamorphic rocks. Crushed gravels showed PN values greater than some crushed dolomites and crushed limestones. Crushed gravel sources should be considered for bituminous surface courses if they meet the standard requirements for Class A stone.

For carbonate aggregates, the difference in mineral hardness within an aggregate piece has a significant effect on friction resistance. Uneven texture after polishing yields a high PV. Materials that yield a contrast in hardness are: quartz vs. calcite, calcite vs. insoluble materials, dolomite vs. calcite, impure dolomite and impure limestone.

Certain geologic formations yield impure aggregate sources. The Kokomo Member and
Mississinewa Member are impure carbonates with higher friction values. The Huntington Dolomite and Brassfield Limestone possessing high carbonate purity, showed lower friction values.

Factors greatly affecting PV for dolomite aggregates are IFV, absorption, specific gravity, sodium sulfate loss, elemental Mg content, and percentage of insoluble residue, minus \#200 sieve size. The most influential independent variables for dolomite are absorption and elemental $\mathrm{Mg}$ content.

The important factors affecting PV for limestone aggregates are total insoluble residue and percent insoluble residue, minus \#200 sieve size. In all, the most influential independent variable is the total insoluble residue content.

Considering dolomite and limestone aggregates collectively, the most important variables are absorption, elemental $\mathrm{Mg}$ content and total insoluble residue.

Multiple linear regression equations were developed which can be used to predict PV. These are provided in the report.

As a starting point for further research using the British Polishing Wheel and Pendulum test the following is proposed:

\begin{tabular}{|c|c|}
\hline $\begin{array}{l}\text { Minimum } \\
\text { Polish Value }\end{array}$ & $\begin{array}{l}\text { Frictional Resistance } \\
\text { of Bituminous Surface }\end{array}$ \\
\hline 24 or less & Poor \\
\hline 25 to 30 & Marginal \\
\hline 31 or more & Good \\
\hline
\end{tabular}

For the calcareous sandstones studied, as total insoluble residue content increases (quartz, clay), PV also increases. With an increase in the ratio of plus \#200 to minus \#200 size insoluble residue, $\mathrm{PV}$ also increases.

Sandstones in the study showed a higher average PV (33.61) than did carbonate aggregate $(\mathrm{PV}=28.50$ for dolomite and $\mathrm{PV}=24.77$ for limestone) because of the heterogeneity of the calcareous sandstones. Quartz, calcite and clay provide this varied composition.

\section{Implementation}

Higher elemental Mg values for dolomite aggregates indicate a greater presence of dolomite mineral. Such aggregates experience a lower PV. For the INDOT specifications, a minimum $10.3 \%$ elemental $\mathrm{Mg}$ is required for carbonate aggregates when used in surface courses with intermediate traffic requirements. Based on results of this study, dolomites with 
less than $10.3 \%$ elemental $\mathrm{Mg}$ should be considered for aggregate use if other requirements such as absorption and soundness are met. Impure limestones, containing clay, quartz or dolomite should also be considered if they meet those same requirements.

Carbonates with higher insoluble residue contents show a higher friction resistance than do purer carbonates with their low insoluble residue values. Data on insoluble residue content including grain size evaluation (+\#200 size fraction vs - \#200 size fraction) should also be determined. A data base for aggregates used in bituminous wearing courses should be compiled by INDOT which includes the insoluble residue content and absorption. Elemental $\mathrm{Mg}$ and Elemental $\mathrm{Cu}$ should also be determined.

A discrepancy in PV was observed between two pieces of test equipment for the British Pendulum test (Purdue University equipment vs Alabama DOT equipment). Before BPN is selected as a standard criterion for evaluating aggregate quality in Indiana, the standard method must be developed using new equipment and a detailed evaluation of inherent variations. PVs need to be evaluated on a continuing basis because PV can vary even within the same aggregate source.

Some impure limestones with a higher frictional value should be considered as a source for bituminous overlays, but field performance of these limestones must be verified through field and laboratory evaluation prior to their use as overlays.

Additional testing using new Polishing Wheel and Pendulum test equipment should be conducted on Indiana aggregates to verify these results. INDOT studies assisted by research performed at Purdue University should address this objective.

\section{Contact}

For more information:

Prof. Terry West

Principal Investigator

Dept. of Earth \& Atmospheric Sciences

Purdue University

West Lafayette, IN 47907

Phone: (765) 494-3296

Fax: (765) 496-1210

\section{Dr. Khaled Galal}

Project Administrator

Indiana Department of Transportation

Division of Research

1205 Montgomery Street

P.O. Box 2279

West Lafayette, IN 47906

Phone: (765) 463-1521, Ext. 252

Fax: (765) 497-1665
Indiana Department of Transportation

Division of Research

1205 Montgomery Street

P.O. Box 2279

West Lafayette, IN 47906

Phone: (765) 463-1521

Fax: (765) 497-1665

Purdue University

Joint Transportation Research Program

School of Civil Engineering

West Lafayette, IN 47907-1284

Phone: (765) 494-9310

Fax: (765) 496-1105 


\section{TABLE OF CONTENTS}

Item

Page

1. Introduction

2. Problem Statement $\quad$.....................................

3. Objectives $\quad$....................................9

4. Work Plan $\quad$................................... 10

5. Analysis of Data

5.1 Gravel Study $\quad$....................................... 12

5.1.1 Selection of Samples for Examination $\quad$.................................. 12

5.1.2 Examination of Gravels $\quad$...................................... 14

5.1.3 Physical Properties of Gravels $\quad$.......................................... 14

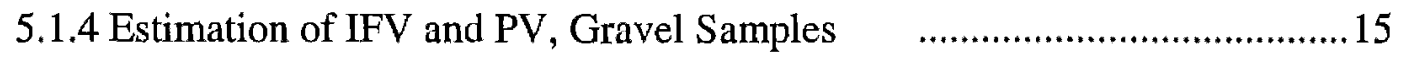

5.1.5 Correlation of Frictional Properties, Gravel Samples ............................... 18

5.2 Carbonate Rock Study $\quad$...................................... 19

5.2.1 Aggregate Lithology and Frictional Properties ....................................26

5.2.2 Physical Properties and Frictional Properties, Carbonate Aggregates .........32

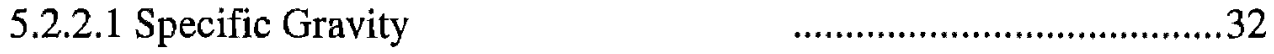

5.2.2.2 Absorption $\quad$..........................................33

5.2.2.3 Sodium Sulfate Soundness $\quad$........................................33

5.2.2.4 Freeze and Thaw Loss $\quad$......................................33

5.2.2.5 L.A. Abrasion Loss $\quad$.................................... 34

5.2.3 Magnesium Content and Frictional Properties, Carbonate Aggregates ......34

5.2.4 Acid Insoluble Residue and Frictional Properties, Carbonate Aggregates.45

5.2.5 Field and Laboratory Testing $\quad$....................................46

5.3 Categorization of Carbonate Aggregates $\quad$.........................59

5.3.1 Selection of Critical Parameters $\quad$.......................................59

5.3.2 Regression Analysis of Laboratory Data $\quad$................................6 60 
5.3.2.1 Dolomite Aggregates $\quad$....................................6 60

5.3.2.2 Limestone Aggregates $\quad$......................................66

5.3.2.3 Integrating Dolomite and Limestone Data..................................62

5.3.3 Categorization of Polished Values $\quad$.....................................63

5.4 Sandstone Study $\quad$.......................................6

5.4.1 Selection of Sandstone Samples $\quad$......................................68

5.4.2 Physical Properties, Sandstone Samples $\quad$....................................6 68

5.4.3 Magnesium Content and Acid Insoluble Residue, Sandstone Samples .....68

5.4.4 Frictional Properties, Sandstone Samples $\quad$.....................................70

5.5 Variation of Frictional Resistance Values $\quad$....................................

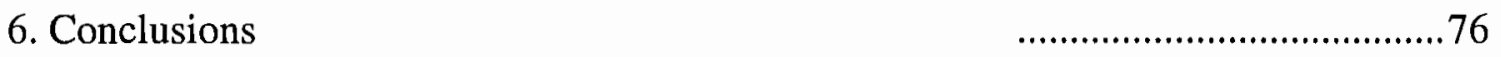

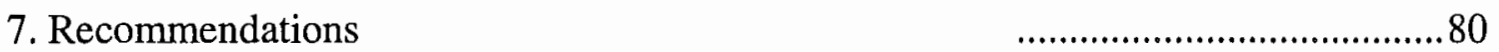

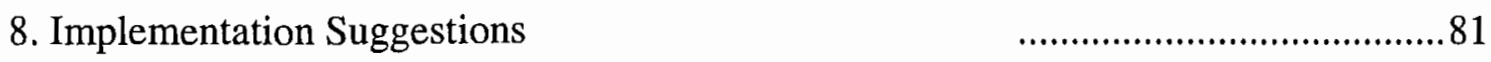

9. References Cited $\quad$.......................................83

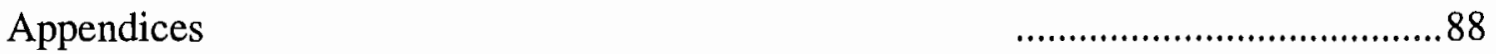

Appendix 1. Confidence Interval for R Values (Fisher's Transformation)..............89

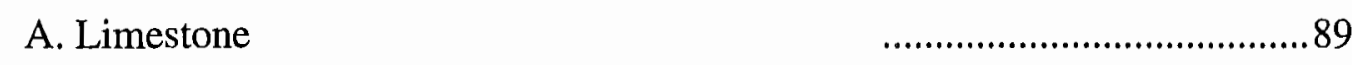

B. Dolomite $\quad$......................................99

C. Gravel $\quad$.....................................99 91

Appendix 2. Correlation Analysis $\quad$.....................................92

A. Limestone $\quad$.................................... 92

B. Dolomite $\quad$......................................99

C. Gravel $\quad$........................................98 98

D. Carbonate $\quad$..................................... 101

Appendix 3. Multiple Regression Analysis $\quad$...................................... 104

A. Limestone $\quad$.................................... 104

B. Dolomite $\quad$..................................... 107

C. Carbonate $\quad$...................................... 110 


\section{LIST OF TABLES}

Table

Page

5-1 Rock type distribution in gravel samples $\quad$......................................16

5-2 Physical properties of gravel samples $\quad$.................................. 16

5-3 IFV and PV for rock constituents in gravel samples ............................... 17

5-4 Weighted average of IFV and PV for gravel samples ................................ 17

5-5 Correlation matrix for gravel aggregate $\quad$....................................21

5-6 BPN and physical properties, $\mathrm{Mg}$ contents and insoluble residues
A) Limestone 24
B) Dolomite
.............................................25

5-7 Frictional properties of carbonate aggregate samples ..............................27

5-8 Elemental $\mathrm{Mg}$ content of carbonate aggregate samples ................................29

5-9 Correlation matrix for carbonate aggregate
A) Limestone 56
B) Dolomite

5-10 Comparison between measured PV and predicted PV by regression analysis
A) Limestone .65
B) Dolomite 66

5-11 Physical properties of sandstone samples $\quad$....................................69

5-12 Elemental Mg content and acid-insoluble residue, sandstone samples ...........69

5-13 IFV, PV and WI for sandstone samples

5-14 Comparison of Polished Values of gravel aggregates from BPT1 and BPT2 .71

5-15 Polished Values of limestone aggregates from BPT1 and BPT2 .................72

5-16 Polished Values of dolomite aggregates from BPT1 and BPT2 ...................73

5-17 Polished Values of sandstone aggregates from BPT1 and BPT2 .................74 


\section{LIST OF FIGURES}

Figure

Page

1-1 Percent dolomite in carbonate aggregates related to percent $\mathrm{MgO}$ and $\mathrm{Mg}$ content for bituminous surface courses

5-1 Location map of aggregate sources

5-2 Rock type distribution of gravel samples

5-3 Correlation of IFV and percent of crushed gravels in gravel samples ....

5-4 Correlation of PV and percent of crushed gravels in gravel samples..............20

5-5 Generalized bedrock map of Indiana $\quad$...................................20

5-6 Generalized columnar sections showing rock units, except Ordovician, quarried for crushed stone in Indiana

5-7 Elemental Mg content of dolomite samples $\quad$....................................30

5-8 Elemental $\mathrm{Mg}$ content of limestone samples $\quad$....................................30

5-9 Acid insoluble residue of dolomite samples $\quad$..................................... 31

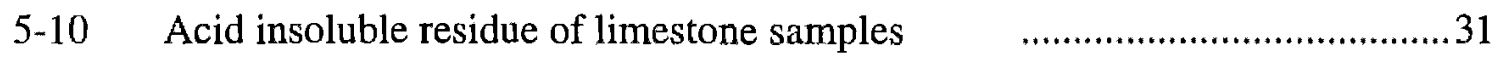

5-11 Correlation of polished value and specific gravity in dolomite samples..........35

5-12 Correlation of wear index and specific gravity in dolomite samples ..............35

5-13 Correlation of polished value and specific gravity in limestone samples ........36

5-14 Correlation of wear index and specific gravity in limestone samples .............36

5-15 Correlation of polished value and absorption in dolomite samples................37

5-16 Correlation of wear index and absorption in dolomite samples ......................37

5-17 Correlation of polished value and absorption in limestone samples ................38

5-18 Correlation of wear index and absorption in limestone samples .....................38

5-19 Correlation of polished value and sodium sulfate soundness in dolomite samples

5-20 Correlation of wear index and sodium sulfate soundness in dolomite samples 
Figure

5-21 Correlation of polished value and sodium sulfate soundness in limestone samples

5-22 Correlation of wear index and sodium sulfate soundness in limestone samples40

5-23 Correlation of polished value and L.A. Abrasion in dolomite samples...........41

5-24 Correlation of wear index and L.A. Abrasion in dolomite samples ................41

5-25 Correlation of polished value and L.A. Abrasion in limestone samples .........42

5-26 Correlation of wear index and L.A. Abrasion in limestone samples ..............42

5-27 Correlation of polished value and $\mathrm{Mg}$ content in dolomite samples ...............43

5-28 Correlation of wear index and $\mathrm{Mg}$ content in dolomite samples....................43

5-29 Correlation of polished value and $\mathrm{Mg}$ content in limestone samples ..............44

5-30 Correlation of wear index and $\mathrm{Mg}$ content in limestone samples ...................44

5-31 Correlation of polished value and total insoluble residue in dolomite samples48

5-32 Correlation of wear index and total insoluble residue in dolomite samples.....48

5-33 Correlation of polished value and total insoluble residue in limestone samples49

5-34 Correlation of wear index and total insoluble residue in limestone samples ...49

5-35 Correlation of polished value and insoluble residue $>\# 200$ in dolomite samples

5-36 Correlation of wear index and insoluble residue $>\# 200$ in dolomite samples..50

5-37 Correlation of polished value and insoluble residue $>\# 200$ in limestone samples

5-38 Correlation of wear index and insoluble residue $>\# 200$ in limestone samples 51

5-39 Correlation of polished value and insoluble residue $<\# 200$ in dolomite samples .52

5-40 Correlation of wear index and insoluble residue $<\# 200$ in dolomite samples..52

5-41 Correlation of polished value and insoluble residue <\#200 in limestone samples

5-42 Correlation of wear index and insoluble residue $<\# 200$ in limestone samples 53 
5-43 Correlation of polished value and insoluble residue $>\# 200 /<\# 200$ in limestone samples

5-44 Correlation of wear index and insoluble residue $>\# 200 /<\# 200$ in limestone samples

5-45 Correlation of polished value and insoluble residue $>\# 200 /<\# 200$ in dolomite samples

5-46 Correlation of wear index and insoluble residue $>\# 200 /<\# 200$ in dolomite samples

5-47 Correlation of average friction number from ribbed trailer tire to IFV and PV determined from coupons composed of extracted core aggregates

5-48 Correlation of average friction number from smooth trailer tire to IFV and PV determined from coupons composed of extracted core aggregates

5-49 Prediction of polished value by the absorption and elemental $\mathrm{Mg}$ content in dolomite aggregates

5-50 Non-linear relationship between polished value and elemental $\mathrm{Mg}$ content in carbonate aggregates

5-51 Comparison of Polished Values from BPT1 and BPT2 according to aggregate types 


\section{List of Abbreviation}

AASHTO -- American Association of State Highway and Transportation Officials $\mathrm{AB}$-- Absorption

AFN - Average Friction Number

ASTM -- American Society for Testing and Materials

BPN -- British Pendulum Number

DOL -- Dolomite

FNR -- Friction Number Ribbed

FNS -- Friction Number Smooth

F-T -- Freeze-Thaw Loss

IFV -- Initial Friction Value

IG - Igneous Rock

INDOT - Indiana Department of Transportation

ITM -.. Indiana Test Method

ISM -- Indiana Standard Method

LA -- Los Angeles Abrasion Loss

LS -- Limestone

META -- Metamorphic Rock

MG -- Elemental Mg Content

MgO -- Magnesium Oxide

M_200 - Insoluble Residue < \#200 sieve

OS -- Other Sedimentary Rock

P_200 -- Insoluble Residue > \# 200 sieve

PV -- Polished Value

SPG -- Specific Gravity

SUL - Sulphate Soundness Loss

T_ACID -- Total Acid Insoluble Residue

WI -- Wear Index 


\section{INTRODUCTION}

The goal of this project is to extend the knowledge obtained from the 1995 JTRP study directed by T.R. West (Bruner, Choi and West, 1995) which focused mostly on dolomite aggregate sources to additional aggregate types, such as limestones, gravels and selected sandstones. Dolomite was the focus of the 1995 study because of its prevalent use in bituminous surface pavements for medium and high vehicular traffic roads.

Bituminous courses are placed over concrete pavements after the concrete has experienced years of wear from highway traffic. The coarse aggregate in the bituminous overlay must supply the primary roughness to yield needed resistance for braking. Although most coarse aggregate types in new bituminous pavements initially provide high friction values, polishing of the coarse aggregate to an equilibrium level eventually occurs. The extent of polishing an aggregate will experience is a function of rock type and gradation, as well as its physical and chemical properties.

For high vehicular traffic roads, equal amounts of dolomite and blast furnace slag are used as the coarse aggregate in bituminous surfaces. A minimum value of $10.3 \%$ elemental $\mathrm{Mg}$ ( $78.1 \%$ dolomite) is required for aggregates to qualify as an acceptable dolomite material. As high purity dolomites occur in only certain geologic formations in Indiana and therefore, in only certain locations, high purity dolomite aggregate must be shipped long distances to produce the bituminous surfaces for paving projects on Interstate highways. These greater transportation distances greatly increase the cost of construction.

The results of the study by Bruner, Choi and West (1995) suggest that some limestones may provide equal or better frictional resistance than do some dolomites that qualify because of their elemental $\mathrm{Mg}$ content. Difficulties can arise when attempting to isolate the major factors influencing polish and friction properties, and prioritizing those parameters because of their indeterminate and interrelated nature. The frictional resistance of the limestone and dolomite aggregates is controlled by their physical and chemical properties. 
A detailed petrographic examination is necessary to determine the texture and composition of aggregates. The two most important, direct textural parameters affecting frictional properties are grain size and shape. Angular grains, at least initially, have a tendency to develop harshly textured surfaces and provide a greater degree of resistance as compared to rocks containing smooth grains. Dierstein and LaCroix (1984) reported that resistance to polishing effects of aggregates is related to grain size, hardness and durability. Larger and harder grains generally provide greater friction values. As an example to illustrate this relationship, Dierstien and LaCroix compared dolomite and limestone sources. Dolomites with generally larger and harder grains, proved superior to limestones. Shupe (1960) noted that particle-by-particle type of wear in rocks such as sandstone consisting of hard quartz and weak calcite matrix was related with high friction values. In a study by Shakoor and West (1979), grain size and particle shape were found to affect polish and thus friction properties; however, they contributed to a lesser degree than did composition. According to the 1995 JTRP study (Bruner, Choi and West, 1995), texture of dolomite aggregates such as grain shape and grain size did not relate well with frictional resistance. Only median grain size showed a high correlation to Polished Values.

Therefore, in this study, the major consideration is given to the compositional properties of dolomite and limestone aggregates to find the critical factors that provide some limestones with a better performance in skid resistance.

As mentioned previously, composition has been found to be a principal factor influencing aggregate performance. Review of the study by Russell (1972), provides the reason why magnesium content was selected as the criterion for acceptance of dolomite aggregates in Indiana. A high percentage of $\mathrm{MgO}$ corresponds directly with a high dolomite concentration. Russell's study of Illinois aggregates showed that percent $\mathrm{MgO}$ had a positive correlation with friction value, that is, greater friction values occurred with increases in $\mathrm{MgO}$ content. In this study Russell considered dolomite aggregate to consist of $>50 \%$ dolomite mineral or $10.9 \% \mathrm{MgO}$. However, in a study on dolomite aggregates by Bruner, Choi and West (1995), the higher elemental Mg content of dolomite correlates 
with smaller PV (Polished Value) and higher WI (Wear Index). This means that dolomites with a high elemental $\mathrm{Mg}$ content polish easier under traffic conditions.

The amount of dolomite can be calculated from the percent of elemental $\mathrm{Mg}$ or from the percent of $\mathrm{MgO}$ in the following way.

a) $\mathrm{Mg}$ in Dolomite $=\frac{\text { Molecular Weight of } \mathrm{Mg}}{\text { Molecular Weight of }\left(\mathrm{CaMg}^{\prime}\left(\mathrm{CO}_{3}\right)_{2}\right.}=\frac{24.31 \mathrm{~g}}{184.4 \mathrm{~g}}=0.1318$

$\%$ Dolomite $=\frac{\% \text { Elemental } \mathrm{Mg}}{0.1318}$

Therefore $10.3 \%$ elemental magnesium corresponds to $78.1 \%$ dolomite, whereas $13.2 \%$ corresponds to $100 \%$ dolomite and $50 \%$ dolomite corresponds to $6.6 \% \mathrm{Mg}$.

b) $\mathrm{MgO}$ in Dolomite $=\frac{\text { Molecular Weight of } \mathrm{MgO}}{\text { Molecular Weight of }(\mathrm{CaMg})\left(\mathrm{CO}_{3}\right)_{2}}=\frac{40.32 \mathrm{~g}}{184.4 \mathrm{~g}}=0.2186$

$$
\% \text { Dolomite }=\frac{\% \mathrm{MgO}}{0.2186}
$$

Therefore $10.93 \% \mathrm{MgO}$ corresponds to $50 \%$ dolomite whereas $21.865 \mathrm{MgO}$ corresponds to $100 \%$ dolomite and $78.1 \%$ dolomite corresponds to $17.07 \% \mathrm{MgO}$.

A comparison of the representation of $\mathrm{Mg}$ and $\mathrm{MgO}$ in dolomite is illustrated in Figure 1-1. As shown in this figure, acceptable dolomite amount for Dlinois DOT use ranges from 50 to $100 \%$ dolomite ( 10.93 to $21.86 \% \mathrm{MgO}$ ) whereas for INDOT, acceptable dolomite amounts ranges from 78.1 to $100 \%$ dolomite $(10.3$ to $13.19 \% \mathrm{Mg}$ ).

In a study performed by Shupe (1958), an increase in magnesium content for Indiana limestone sources showed an increase in friction properties. In other words, the less pure limestones having greater magnesium content and thus greater mineral diversity were better aggregates with regard to frictional resistance. 


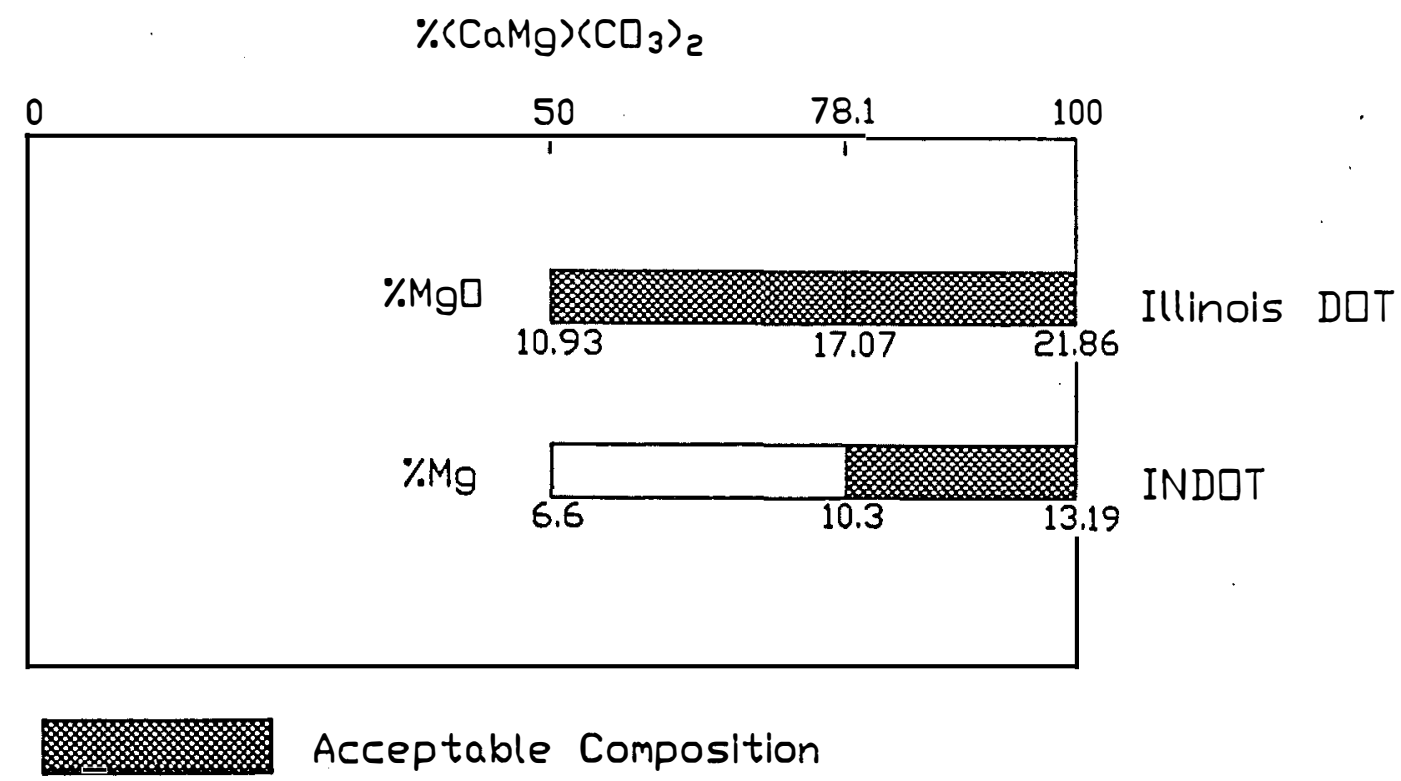

Figure 1-1. Percent dolomite in carbonate aggregates related to percent $\mathrm{MgO}$ and $\mathrm{Mg}$ content for bituminous surface courses

Russell also observed a negative correlation between friction value and quartz content for these dolomite sources. A general decrease in friction value was also observed with an increase in the calcite concentration.

Russell's study of carbonate aggregates, and that by Cummings (1976) focused on acid-insoluble residue content. Russell's study included carbonate aggregates containing less than 12 percent insoluble residue. A positive correlation was found between acidinsoluble residues $>75$ microns in size and friction values for the dolomite aggregates; however, little correlation was found between these factors for carbonate aggregates in general. Cummings analyzed aggregates containing up to 25 percent acid-insoluble residue. He found a positive correlation with friction value for dolomite aggregates containing insoluble-residue retained on the No. 200 sieve, as well as with the ratio between the No. 30 and No. 200 sieves. In essence, regarding those aggregates with greater than 70 percent insoluble material retained on the No. 30 sieve, they show poor 
results in terms of friction values as compared to samples whose majority of insoluble material occurred on the No. 200 sieve.

Dierstein and LaCroix (1984) also indicated a relationship between acid-insoluble residue and friction values. They concluded that grain size was the primary mechanism affecting variation in friction values for carbonates containing less than 10 percent insoluble content. At greater than 25 percent, the sand size acid-insoluble residue generally accounts for higher friction values.

Dahir and Mullen (1971) observed that skid resistance increases with an increase in the amount of insoluble residue, sand size residue probably is more important than total residue and the presence of clay generally contributes to lower frictional resistance. They also mentioned that skid resistance was higher for aggregate having mixed composition of hard and soft minerals than for aggregate consisting predominantly of minerals of the same type with the same hardness.

Sherwood and Mahone (1970) mentioned the positive relationship between the amount of acid insoluble residue and frictional values of carbonate rocks. Also they noticed that size distribution of the insoluble fraction affects pavement friction values. The better relationship may exist between total insoluble residue and friction coefficient.

In the study by Bruner, Choi and West (1995), involving dolomite aggregates, insoluble residue does not correlate with WI (Wear Index). However, dolomite aggregates containing greater amounts of insoluble residue less than \#200 size show a higher PV (Polished Value).

The common physical tests considered to have major influence on aggregate performance are absorption, soundness, abrasion and specific gravity. Senior and Rogers (1991) provided a thorough overview of the first three of these parameters and their significance in evaluating highway aggregates. They indicated that the abrasion loss was increased nine units with additional moisture content of 5 percent. Aggregate type also influences the test results. Generally, weaker argillaceous rocks have a tendency to absorb the impact of the steel balls, whereas coarse-grained crystalline materials do not and they experience higher losses. 
The sodium sulfate soundness test is a measure of an aggregate's durability and thus, its resistance to weathering. For INDOT, sodium sulfate testing was previously used to determine aggregate soundness but currently it is performed only occasionally. Because of problems obtaining reproducible results for sodium sulfate testing, unconfined freeze-thaw testing is now used as a replacement.

A relationship between absorption and freeze-thaw resistance is known to exist. Although there are exceptions, aggregates with high absorption generally have lower freeze-thaw resistance. Senior and Rogers (1991) concluded that the following combinations of tests; Los Angeles abrasion loss, sodium sulfate loss, and absorption; can be used to differentiate between good and poor aggregates. However, these tests are not particularly accurate in predicting the performance of marginal aggregates. Therefore, as indicated above, these physical tests have some shortcomings regarding the prediction of field performance for frictional resistance.

Specific gravity is related to composition and absorption. Variations in composition within an aggregate source increase with differential polishing. The presence of compositional variation has been shown to reduce the effects of polishing by vehicular traffic.

In a study by Bruner, Choi and West (1995), for dolomite aggregates, Los Angeles abrasion did not show a correlation with either WI or PV. However, dolomites with higher absorption values show lower WI and higher PV. Also higher specific gravities correlated with lower PV and higher WI. The dolomites showing higher sulfate soundness also show a higher PV and lower WI. However, the correlation between the Los Angeles abrasion loss and frictional resistance was not significant. 


\section{PROBLEM STATEMENT}

The highway pavement system requires aggregates of multifunctional characteristics to meet various demands. For bituminous wearing courses these characteristics not only include strength and durability but also adequate frictional resistance. Aggregate having all these properties frequently are not locally available and have to be imported which thereby increases transportation costs.

Natural aggregates used in highway construction in Indiana are crushed carbonate rocks and glacial river gravels. This includes both base courses and aggregates for the pavement itself. Historically, dolomites have been specified for use in surface courses for medium volume roads and a combination of dolomite and blast furnace slag used for surface courses of high volume roads.

Following pavement construction, the frictional resistance of pavement is monitored after specific time intervals using the ASTM procedure, "Towed Friction Trailer" (ASTM Standard E-274). When the FNS (Friction Number Smooth) or FNR (Friction Number Ribbed) fall below a critical value, replacement of the overlay is considered.

In 1995 a 2-1/2 year JHRP study on the contribution of aggregates to frictional resistance of bituminous surfaces was completed under the direction of T.R. West (Bruner, Choi and West, 1995). In this study coupon samples of aggregates were evaluated using the British Polishing Wheel and the British Pendulum Tester. Also a comparison was made to the frictional resistance of pavements as measured by the skid trailer.

Detailed petrographic evaluation and compilation of laboratory data allowed for the correlation of frictional resistance measurements. Because of its prevalent use in medium and high vehicular traffic roads, dolomite was the primary aggregate type studied, along with selected examples of crushed stream gravels. Low volume vehicular traffic roads are those with less than 1 million ESALs, or Equivalent Single Axel Loads, whereas medium volume roads have from 1 to 3 million ESALs. Limestones, because of their limited use in medium and high vehicular traffic roads, were represented by only 
two examples in this study. This did not adequately depict the range of characteristics shown by limestone aggregates. Despite this limited number of samples, these limestones performed better in the British Pendulum Tester than did some of the dolomite samples from approved sources.

For high vehicular traffic roads, equal amounts of dolomite and blast furnace slag are used as the coarse aggregate in bituminous surfaces. This is to provide a greater frictional resistance for the pavement surface. Based on past research on carbonate rocks it had been concluded that high purity dolomites provide a better frictional resistance in pavements than do limestones. However, the study by Bruner, Choi and West (1995) noted that impure dolomites having low elemental $\mathrm{Mg}$ content provided better frictional resistance. Elemental magnesium is used as an indication of dolomite content as dolomite has the composition $\mathrm{CaMg}\left(\mathrm{CO}_{3}\right)_{2}$. A minimum value of $10.3 \% \mathrm{Mg}$ is required for aggregates to qualify as an acceptable dolomite material, which corresponds to $78.1 \%$ dolomite (INDOT Specifications, 1999). As high quality dolomites occur in only certain geologic formations in Indiana and therefore, in only certain locations, high quality dolomite aggregates are commonly shipped long distances to produce the bituminous surfaces for paving projects on Interstate highways. These greater transportation distances greatly increase the cost of construction.

Results of the study by Bruner, Choi and West (1995) suggest that some limestones may provide equal or better frictional resistance than do some dolomites that qualify because of their elemental $\mathrm{Mg}$ content. In the current study, in order to determine factors other than elemental $\mathrm{Mg}$ content that affect high quality limestone performance, various limestone aggregates were evaluated to determine their frictional resistance based on the British Polishing Wheel and Pendulum Tester. Acid insoluble residue and $\mathrm{Mg}$ content of carbonates showed considerable promise in the previous study, and therefore would be conducted on the limestone samples as well. 


\section{OBJECTIVES}

The objectives of this study were to 1) Extend the knowledge obtained from FHWA/IN/JHRP-95/11 (Bruner, Choi and West, 1995) by evaluating gravels, limestones and sandstones, and expanding the base of dolomites. 2) Find factors that gave some limestones a higher frictional resistance on bituminous pavement, and 3) Develop specifications, if possible, to allow certain limestones and crushed gravels to be used in

medium and high vehicular traffic roads.. To accomplish this, additional aggregate types, such as limestones, gravels and selected sandstones would be evaluated. Dolomite had been the focus of the 1995 study because of its prevalent use in surface pavement for medium and high vehicular traffic roads.

For high vehicular traffic roads equal amounts of dolomite and blast furnace slag are used as the coarse aggregate in the bituminous surface. A minimum value of $10.3 \%$ elemental $\mathrm{Mg}$ is required for aggregates to qualify as an acceptable dolomite material, which corresponds to $78.1 \%$ dolomite in the sample. As high quality dolomites occur in only certain geologic formations in Indiana and therefore, in only certain locations, high quality dolomite aggregates are commonly shipped long distances to produce the bituminous surfaces for paving projects on interstate highways. These greater transportation distances significantly increase the cost of construction.

Therefore, this study focuses on high quality limestones. These aggregates were sampled and analyzed in order to find the factors that give limestone higher frictional resistance for bituminous pavement. Results of this study will be used to evaluate frictional resistance provided by various aggregate types. Development of specifications that allow certain limestones and crushed gravels to be used in high vehicular traffic roads is a stated objective. The outcome would be a reduction in cost of materials for road construction or resurfacing of medium and high vehicular traffic projects including interstate highway projects. 


\section{WORK PLAN}

The work plan builds on the results obtained in the previous JTRP study directed by T.R. West (Bruner, Choi and West, 1995). Predominantly, dolomite sources were included in that study. In the current study, additional rock types including limestones, crushed gravels and selected sandstones were chosen from those specifically addressed under the INDOT Specification.

First, through a meeting with $\mathrm{SAC}$ members, the aggregate sources including limestones, crushed gravels and sandstones were selected for study. Input from INDOT (Division of Materials and Tests), FHWA and industry (Indiana Mineral Aggregates Association and representatives of aggregate suppliers) was obtained.

A total of 21 sources of limestone aggregates, 3 sources of sandstones and 6 sources of crushed gravels were collected based on bedrock formation, rock types, texture, composition and geographic location (ASTM Standard C702, D75).

Following aggregate collection, megascopic and microscopic observations on the aggregate sources were accomplished. A total of 24 rock thin sections were made for the limestone and sandstone sources.

Also, laboratory tests including acid insoluble residue (ASTM Standard D3042), size distribution of the acid insoluble residue, elemental Mg content (ASTM Standard C602 and Atomic Absorption Method), Los Angels abrasion (ASTM Standard C131), sulfate soundness (ASTM Standard C88), freeze-thaw loss in water and brine solution (AASHTO Standard Specification, T103 Procedure A), absorption and specific gravity (ASTM Standard C127) were conducted at the INDOT Division of Materials and Tests and at Purdue University. In particular, the acid insoluble residue and $\mathrm{Mg}$ content were used for the identifications of quality limestones.

Aggregate coupons of limestones, sandstones and crushed gravels were made for the British Wheel test and British Pendulum test (ASTM Standard D3319, E303). In order to make aggregate coupons, the largest pieces of crushed stone comprising the No.11 INDOT gradation, $12.5 \mathrm{~mm}$ to $9.5 \mathrm{~mm}$ in size, were selected. To construct the 
coupons the aggregates are embedded in epoxy that has a resin component and a hardener component mixed in a one to one ratio by volume. The aggregate coupons were polished with British Wheel machine and frictional resistance measured with British Pendulum Tester after 0 (Initial Friction Value, IFV), 1 hour, 3 hour, 6 hour and 10 hour (Polish Value, PV) during the polishing process. These data were added to the list of existing information of a similar nature on dolomites from the 1995 study directed by T.R. West (Bruner, Choi and West, 1995).

Finally, analysis of all data to provide results and conclusions relating information from the various tasks was accomplished. Results of this study were compared to those from other states. From this the PV of dolomite and limestone for bituminous surface . pavement required for pavement surfaces can be recommended. Also, results can be used to develop specifications yielding the approval of additional aggregate sources for medium and high vehicular traffic bituminous surface pavements in Indiana. 


\section{ANALYSIS OF DATA}

\section{$\underline{5.1 \text { Gravel Study }}$}

Six gravel sources were selected for this study (Figure 5-1). For these samples a megascopic, petrographic examination was performed and the Initial Friction Value (IFV) and Polish Value (PV) were determined on coupons made from these gravels.

The objective of the petrographic examination for the gravel samples was to describe and classify constituents and determine the relative amounts of these different materials. This method is based on ASTM Standard C295.

The major gravel resources in Indiana are found in landforms deposited directly by glacial melt-water runoff during continental glaciation. At first glance, the composition of the Indiana gravels seems to be a bewildering array of rock and mineral types, and in many samples 10 to 20 varieties of rocks can be found (Carr and Webb, 1970). Included are carbonates, sandstone, siltstone, chert, shale, iron concretion, gneiss, schist, quartzite, granite, granodiorite, diorite, gabbro, andesite, basalt, gabbro, syenite, dacite, rhyolite, amphibolite, and quartz (Shakoor and West, 1979, McGregor, 1960).

\subsubsection{Selection of Samples for Examination}

Approximately $2.5 \mathrm{~kg}$ of a gravel sample were prepared for sieve analysis by reducing the sample material to the required quantity according to ASTM Standard C 702. From this, by sample splitting, 300 representative particles were selected and subsequently examined.

The size ranging from $9.5 \mathrm{~mm}$ to No. $4(4.75 \mathrm{~mm})$ was chosen and fractions smaller than the No. 4 were not included in the analysis. This is because it is generally accepted that the coarse aggregate portion largely determines the skid resistance for bituminous pavements, and the finer portion represents only ten to thirty percent of the total No. 11 size sample used for bituminous surface aggregate. All particles present in the size fraction were examined if they numbered fewer than 300 particles. 


\section{Aggregate Sources}

- Dolomite (Part 1)

* Limestone (Part 2)

- Sandstone (Part 2)

- Gravel (Part 2)

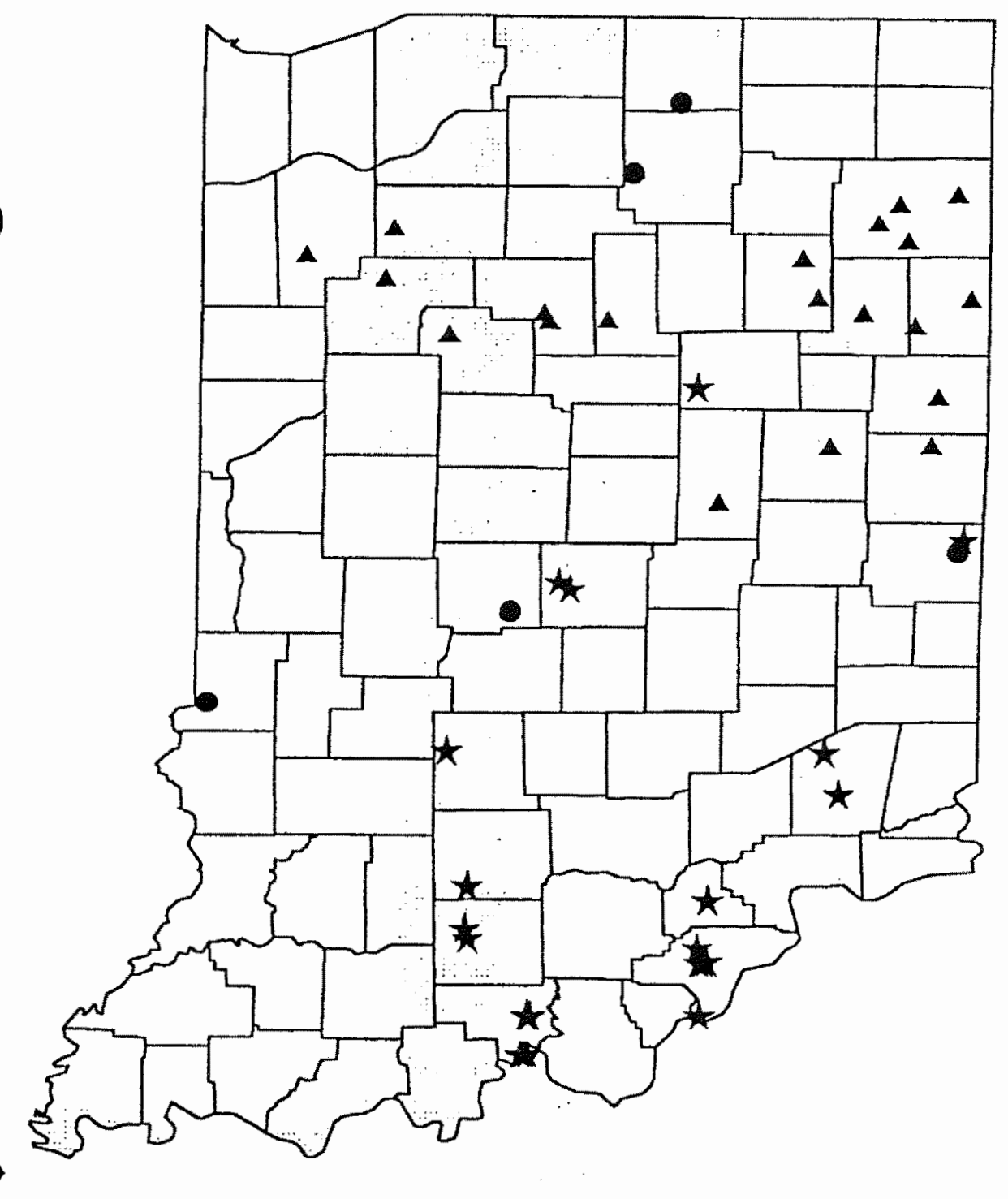

Figure 5-1. Location map of aggregate sources 


\subsubsection{Examination of Gravels}

Rock particles were identified in a wet surface condition that enhances the color and structure of the particles. Hand lens and binocular microscope were used to identify individual rock constituents. Following this, $0.1 \mathrm{~N} \mathrm{HCl}$ was applied on soft rocks to differentiate carbonates from other constituents. Limestones produced a brisk effervescence whereas dolomite showed slow effervescence or produced effervescence only when scratched. Ten rock types were chosen according to their frequency in the sample. If particles of indeterminate type were encountered in the samples, they were included with known types having similar texture and hardness. The ten rock categories selected are limestone, sandstone, siltstone, shale, chert, granite, diorite, felsite, gneiss, and quartzite.

The percentage of crushed particles was determined according to the definition of a fractured face in the Indiana Test Method (TTM) 204. It reads as follows: Fractured surface: A broken surface constituting an area of at least $25 \%$ of the largest cross sectional area of the particle. A fractured particle is defined as one being fractured either by mechanical means or by nature. Natural fractures must be similar to those fractures produced by a crusher.

The ten rock types were collected into five major rock types, that is, igneous, metamorphic, limestone, dolomite and other sedimentary rocks. The petrographic analyses for the gravels are summarized in Table 5-1.

Results show that gravel samples examined consist mainly of carbonates (limestone and dolomite) ranging from 6.6 percent to 56.3 percent. Igneous rock is the second most abundant constituent of the gravel, ranging from 9.0 percent to 49.2 percent, followed next by other sedimentary rocks ranging from 16.0 percent to 46.9 percent. Metamorphic rocks consist of a portion ranging between 3.6 percent and 18.7 percent of gravel samples (Figure 5-2).

\subsubsection{Physical Properties of Gravels}

The physical test results for gravel samples were obtained from INDOT, These test results are listed in Table 5-2. 
According to results of the physical properties of the gravels, absorption ranges from $1.21 \%$ to $3.21 \%$, specific gravity from 2.509 to 2.676 , Los Angeles abrasion loss from $22.64 \%$ to $28.00 \%$ and the freeze and thaw loss in brine solution from 4.49 to 9.18 . For sample GR-6 the freeze and thaw loss in water was performed instead, resulting in $2.06 \%$ loss.

\subsubsection{Estimation of IFV and PV for Gravel Samples}

The aggregate coupons for gravel samples were made using single individual rock types. The Initial Friction Value (IFV) and Polished Value (PV) were measured using the British Pendulum tester. The IFV and PV for gravel aggregates are listed in Table 5-3: According to the results of the British Pendulum test, igneous rocks in gravels have an IFV ranging from 32.2 to 45.6 and a PV ranging from 21.0 to 29.9. Aggregate coupons of metamorphic rocks were made only from GR-1 and GR-6 gravels because not enough metamorphic rock pieces in other gravel sources were present. The metamorphic rocks in gravels show IFV ranging from 39.6 to 43.3 and PV ranging from 27.5 to 28.3 . The limestone in gravels show IFV ranging from 33.2 to 46.6 and PV ranging from 18.6 to 31.4. The dolomite in gravels show IFV ranging from 40.2 to 46.7 and PV ranging from 24.5 to 27.3 . The other sedimentary rocks such as sandstone, shale, siltstone and chert show IFV ranging from 35.2 to 43.7 and PV ranging from 21.6 to 25.3.

As indicated in Table 5-3, it is noted that on average dolomites show higher IFV and PV values than do limestones. Weighted averages of IFV and PV for each gravel sample based on their percentage of rock compositions are summarized in Table 5-4.

As indicated in Figures 5-3 and 5-4, as the percentage of crushed faces of gravel increases, both IFV and PV also increase. In Table 5-5, the percent of crushed gravel faces is more highly correlated with IFV $(R=0.890)$ than with $P V(R=0.804)$. IFV depends more on the percent of the crushed gravel than it does on PV. This shows that the influence of the amount of crushed gravel faces is diminished as the gravels are polished. 
Table 5-1. Rock type distribution in gravel samples

\begin{tabular}{|c|c|c|c|c|c|c|}
\hline Id. No. & $\begin{array}{c}\text { Igneous } \\
\text { Rock }\end{array}$ & $\begin{array}{c}\text { Metamorphic } \\
\text { Rock }\end{array}$ & Limestone & Dolomite & $\begin{array}{c}\text { Other } \\
\text { Sedimentary } \\
\text { Rock }\end{array}$ & Remarks \\
\hline GR-1 & 27.5 & 11.1 & 19.5 & 20.8 & 21.1 & $99 \%$ crushed \\
\hline GR-2 & 35.8 & 3.6 & 20.8 & 21.5 & 18.3 & $30 \%$ crushed \\
\hline GR-3 & 29.7 & 6.8 & 14.1 & 14.7 & 34.7 & $10 \%$ crushed \\
\hline GR-4 & 49.2 & 8.7 & 17.5 & 8.6 & 16.0 & $78 \%$ crushed \\
\hline GR-5 & 9.0 & 3.7 & 15.9 & 40.4 & 31.0 & $57 \%$ crushed \\
\hline GR-6 & 27.8 & 18.7 & 6.2 & 0.4 & 46.9 & $93 \%$ crushed \\
\hline Average & 29.8 & 8.8 & 15.7 & 17.7 & 28.0 & $61 \%$ crushed \\
\hline
\end{tabular}

Table 5-2. Physical properties of gravel samples

\begin{tabular}{|c|c|c|c|c|}
\hline Id. No. & Absorption & Specific Gravity & $\begin{array}{c}\text { L.A. Abrasion } \\
\text { Loss }\end{array}$ & $\begin{array}{c}\text { Freeze/Thaw } \\
\text { Loss in Brine }\end{array}$ \\
\hline GR-1 & $3.21 \%$ & 2.590 & $27.99 \%$ & $9.18 \%$ \\
\hline GR-2 & $1.42 \%$ & 2.593 & $26.26 \%$ & $4.49 \%$ \\
\hline GR-3 & $1.21 \%$ & 2.676 & $22.64 \%$ & $5.67 \%$ \\
\hline GR-4 & $1.33 \%$ & 2.638 & $24.22 \%$ & $4.64 \%$ \\
\hline GR-5 & $1.57 \%$ & 2.645 & $23.19 \%$ & $5.77 \%$ \\
\hline GR-6 & $2.03 \%$ & 2.509 & $28.00 \%$ & $* 2.06 \%$ \\
\hline Average & $1.80 \%$ & 2.609 & $25.38 \%$ & $5.95 \%$ \\
\hline
\end{tabular}

- *: Freeze - thaw loss in water 
Table 5-3. IFV and PV for rock constituents in gravel samples

\begin{tabular}{|c|c|c|c|c|c|c|c|c|c|c|}
\hline \multirow{2}{*}{ Id. No. } & \multicolumn{2}{|c|}{$\begin{array}{c}\text { Igneous } \\
\text { Rock }\end{array}$} & \multicolumn{2}{c|}{$\begin{array}{c}\text { Metamorphic } \\
\text { Rock }\end{array}$} & \multicolumn{2}{|c|}{ Limestone } & \multicolumn{2}{c|}{ Dolomite } & \multicolumn{2}{c|}{$\begin{array}{c}\text { Other } \\
\text { Sedimentary } \\
\text { Rock }\end{array}$} \\
\cline { 2 - 12 } & IFV & PV & IFV & PV & IFV & PV & IFV & PV & IFV & PV \\
\hline GR-1 & 43.3 & 26.3 & 43.3 & 28.3 & 43.3 & 25.3 & 46.7 & 27.3 & 43.7 & 25.3 \\
\hline GR-2 & 32.2 & 21.0 & - & - & 33.2 & 23.1 & 41.7 & 24.6 & 36.6 & 23.1 \\
\hline GR-3 & 34.2 & 21.0 & - & - & 34.2 & 24.1 & 40.2 & 26.9 & 35.2 & 24.1 \\
\hline GR-4 & 40.3 & 23.7 & - & - & 36.3 & 25.3 & 42.3 & 25.3 & 35.3 & 23.6 \\
\hline GR-5 & 40.3 & 24.3 & - & - & 35.7 & 18.6 & 41.6 & 24.5 & 37.2 & 22.6 \\
\hline GR-6 & 45.6 & 29.9 & 39.6 & 27.5 & 46.6 & 31.4 & - & - & 35.7 & 21.6 \\
\hline Average & 39.3 & 24.4 & 41.5 & 27.9 & 38.2 & 24.6 & 42.5 & 25.7 & 37.3 & 23.4 \\
\hline
\end{tabular}

Table 5-4. Weighted average of IFV and PV for gravel samples

\begin{tabular}{|c|c|c|c|}
\hline Identification No. & IFV & PV & Remark \\
\hline GR-1 & 44.1 & 26.3 & $99 \%$ crushed \\
\hline GR-2 & 35.3 & 22.6 & $30 \%$ crushed \\
\hline GR-3 & 35.6 & 23.5 & $10 \%$ crushed \\
\hline GR-4 & 39.0 & 24.1 & $78 \%$ crushed \\
\hline GR-5 & 39.1 & 22.9 & $57 \%$ crushed \\
\hline GR-6 & 39.9 & 25.6 & $93 \%$ crushed \\
\hline Average & 38.8 & 24.2 & $61 \%$ crushed \\
\hline
\end{tabular}

* Example (GR-1):

IFV $=43.3(0.275)+43.3(0.111)+43.3(0.195)+46.7(0.208)+43.7(0.211)=44.1$

$P V=26.3(0.275)+28.3(0.111)+25.3(0.195)+27.3(0.208)+25.3(0.211)=26.3$ 


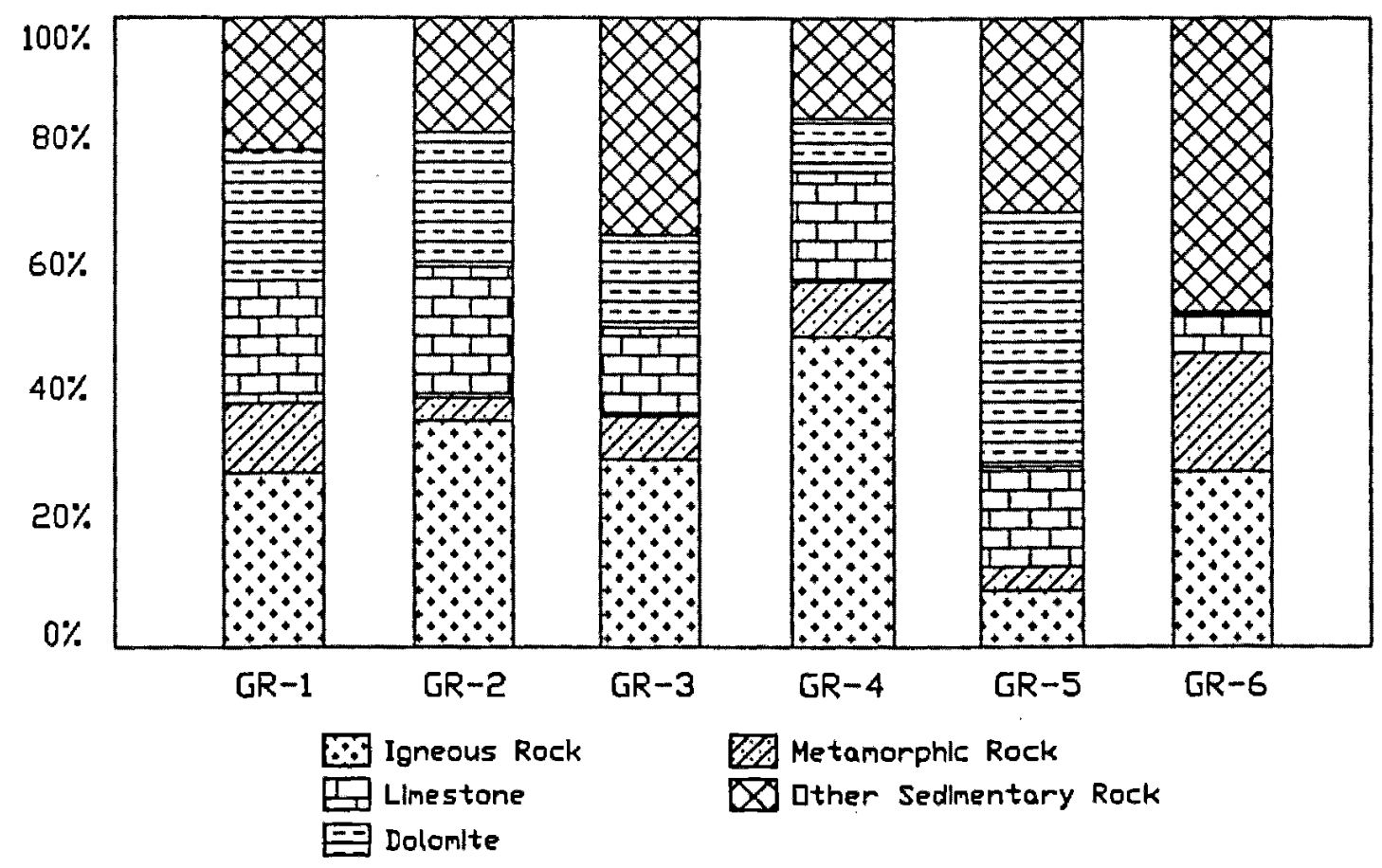

Flgure 5-2. Rock type distribution of gravel samples

\subsubsection{Correlation of Frictional Properties for Gravel Samples}

In order to find the most critical factor for frictional properties of gravels, data analyses for correlations between British Pendulum Number (BPN) and other aggregate properties were performed. Using a correlation analysis (SAS program), the statistics and correlation matrix for all parameters of the gravels were developed as shown in Table 55. The top number (R-value) in each cell is the coefficient of correlation between two variables defining the cell. $\mathrm{R}$-value measures the degree of linear relationship among variables. The middle number ( $\mathrm{P}$-value) in each cell is developed from hypothesis testing and indicates the significance of the correlation; lower P-values imply greater significance. The bottom number in each cell is the number of data used for correlation analysis. For the purpose of this study, the correlation coefficient (R-value) is considered to be low if it falls below 0.50, fair if between 0.50 and 0.80 , and good if above 0.80 (Kandhal et al., 1993). 


\subsection{Carbonate Rock Study}

Results of the current research on limestone aggregates along with those on dolomite aggregates by Bruner, Choi and West (1995) were analyzed collectively. The total number of samples was 21 limestone sources and 20 dolomite sources. The bedrock distribution of principal carbonate rocks and their columnar sections are shown in Figures 5-5 and 5-6, respectively. The lithology of the geologic formations of the carbonate aggregates is described below based on the Indiana Geological Survey Bulletin 59, 1986 and Bulletin 42H, 1971, extending from oldest to youngest rocks.

\section{[Silurian Period]}

- Brassfield Limestone

- Reddish brown and gray coarsely crystalline limestone.

- Total, 1 source: L006

- Salamonie Dolomite

- White to tan porous, fossil-fragmental dolomite. In some places this dolomite grades in two units: an upper cherty limestone and dolomite unit (Laurel Member) and a lower argillaceous dolomitic limestone unit (Osgood Member).

- Total, 8 sources: D002, D010, D011, D012, L003, L009, L010, L011.

- Louisville Limestone

- Bluish-gray silty dolomitic limestones that contain varying amounts of shale. In some areas, this rock is a blue and gray mottled dolomite.

- Total, 3 sources: D008, L008, L012

- Pleasant Mills Formation

- Tan to brown micritic to fine-grained and sugary dolomite that on outcrop appears thin to rather massively bedded but that is also color banded and faintly laminated. Oolites are abundant.

- Total, 3 sources: D007, D009, D020. 


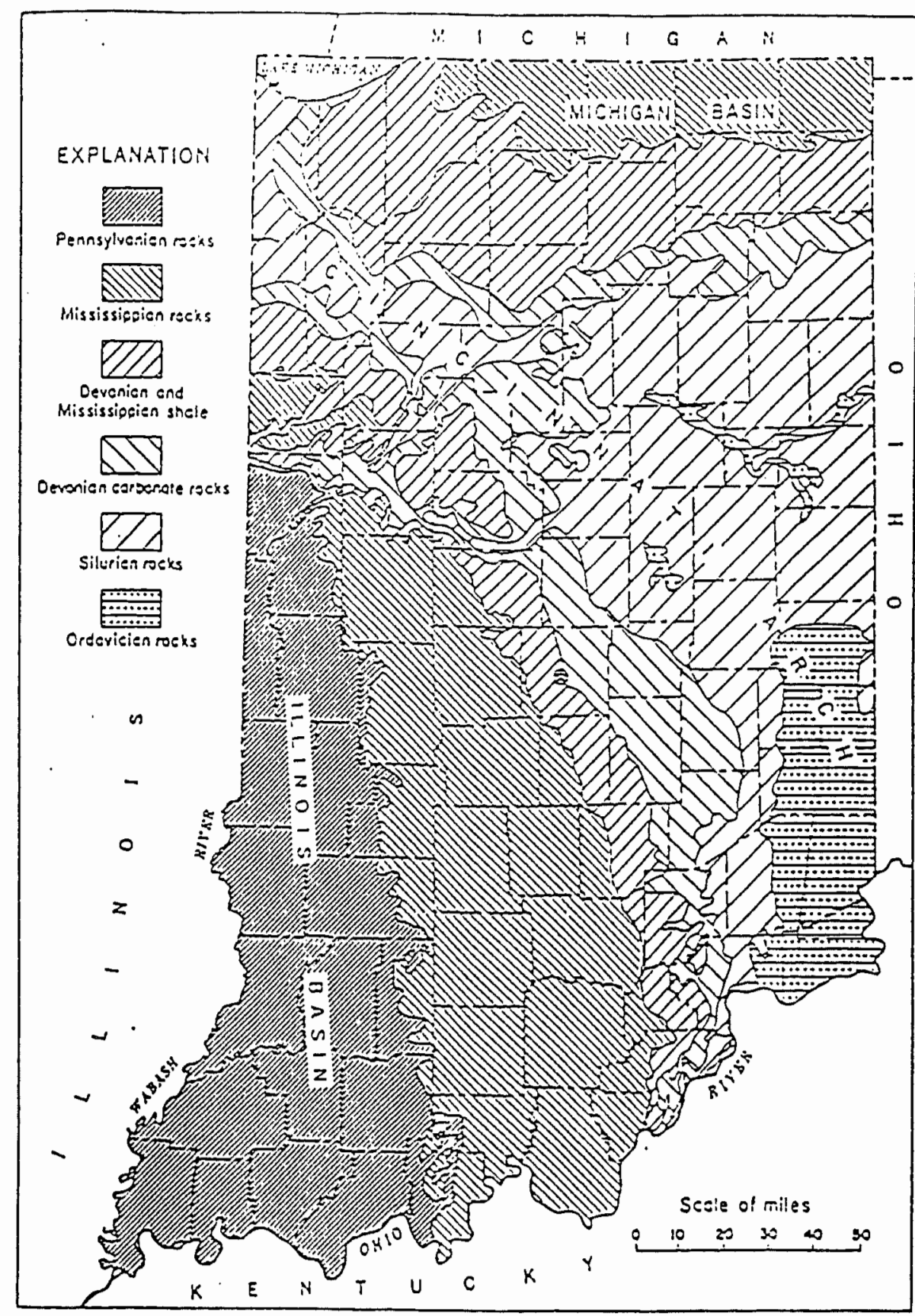

Figure 5-5. Generalized bedrock map of Indiana (Dawson and Carpenter, 1963) 


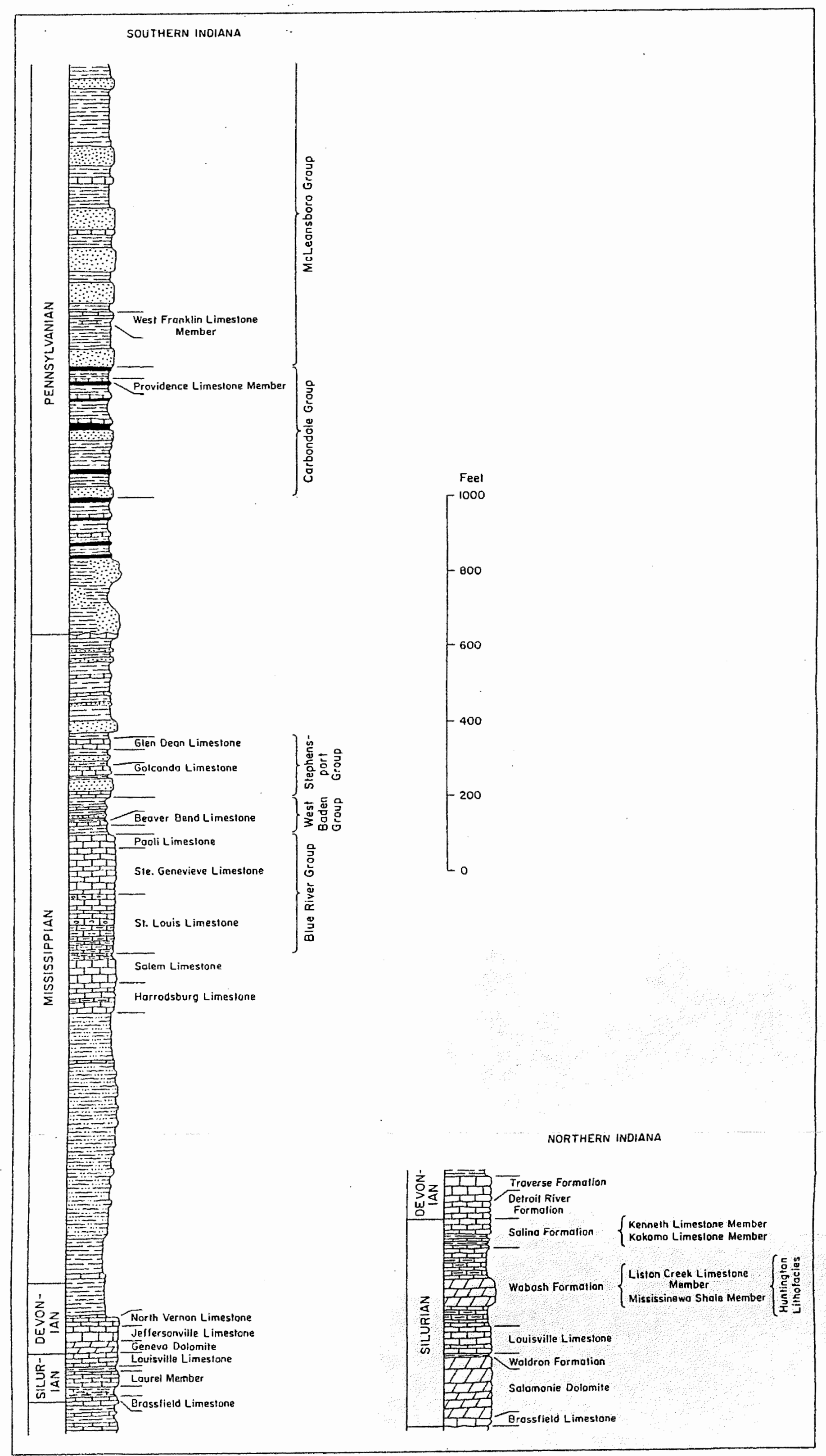

Figure 5-6. Generalized columnar sections showing rock units, except Ordovician, quarried for crushed stone in Indiana (D. D. Carr et al, 1971) 
- Wabash Formation

- Kenneth Member: light-colored dense to fine-grained bedded to massive cherty limestone.

- Kokomo Member: strikingly banded tan and gray micritic to very fine grained, thinly laminated and dolomitic limestone.

- Mississinewa member: argillaceous dolomitic siltstone and silty dolomite, fairly calcareous in places, that is in various shades of gray and is dense to fine grained and massive appearing in un-weathered exposures.

- Huntington dolomite: reef, bank, and biohermal deposits of coarse-grained porous dolomite.

- Total, 10 sources: D001, D004, D005, D013, D014, D015, D016, D017, L001, L004.

[Devonian Period]

- Jeffersonville Limestone

- Grayish-brown carbonaceous limestone or dolomitic limestones. Three fauna zones are present in the formation: the middle and upper zones contain very thin argillaceous and pyretic laminae in places. The lower zone generally does not contain the argillaceous and pyretic laminae.

- Total, 2 sources: L007, L013.

- North Vernon Limestone

- Gray dense massive argillaceous limestone (Silver Creek Member)

- Gray granular to shaly thin-bedded very fossiliferous limestone (Speed Member)

- Gray and dark gray medium-grained and very coarse-grained crinoidal limestone (Beechwood Member)

- Total, 1 source: L002 (mixed with Jeffersonville Limestone).

- Detroit River Formation

- Brownish-gray fine- to coarse-grained limestones and dolomites.

- Total, 3 sources: D003, D018, D019 (mixed with Traverse Formation, Wabash Formation or Louisville Limestone) 
- Traverse Formation

- Brownish-gray calcareous dolomites and dolomitic limestones that contain a few scattered chert bands and shaly layers near the base.

- Total, 3 sources: D003, D018, D019 (mixed with Detroit River Formation, Wabash Formation or Louisville Limestone)

[Mississippian period]

- St. Louis Limestone

- Gray to light brown thin-bedded micritic limestone. Contains small amounts of shale and chert (Upper unit)

- Gray to brown thin-bedded dolomitic limestone interbedded with calcareous shale (Lower unit)

- Total, 1 source: L005 (mixed with Ste. Genevieve limestone)

- Ste. Genevieve Limestone

- Fredonia member: dominantly an oolitic limestone that is from light gray to gray, medium grained.

- Rosiclare member: gray, fine- to medium-grained, crystalline, oolitic limestone, which is locally argillaceous, arenaceous, or conglomeratic. May contain beds of calcareous shale and sandstone.

- Levias Member: light-gray, thin-bedded to massive, crystalline, oolitic limestone

- Total, 2 sources: L015, L016.

- Beaver Bend Limestone

- White to light gray, highly oolitic, thick-bedded to massive limestone.

- Total, 5 sources: L017, L018, L019, L020, L021.

- Haney Limestone

- Dominantly biomicritic and includes skeletal limestone and micritic dolomite with minor shale.

- Total, 1 source: L014 
Table 5-6 BPN and Physical Properties, Mg contents and Insoluble residues

\section{A. Limestone}

\begin{tabular}{|c|c|c|c|c|c|c|c|c|c|c|c|}
\hline Id. No. & IFV & PV & WI & Absorption & Sp. Gravity & LA Abrasion & $\mathrm{F}-\mathrm{T}$ & $\mathrm{Mg}(\%)$ & Insol (Total) & $>\# 200$ & $<\# 200$ \\
\hline L-001 & 38.60 & 28.14 & 10.46 & 2.170 & 2.591 & 28.500 & & 5.40 & 12.72 & 2.40 & 10.32 \\
\hline L-002 & 40.20 & 24.72 & 15.48 & 1.780 & 2.586 & 27.000 & 22.250 & 0.70 & 5.76 & 3.64 & 2.12 \\
\hline$L-003$ & 44.38 & 22.69 & 21.69 & 2.000 & 2.604 & 21.370 & 7.980 & 9.50 & 4.09 & 2.04 & 2.05 \\
\hline $\mathrm{L}-004$ & 43.14 & 23.49 & 19.65 & 1.030 & 2.633 & 32.090 & & 3.60 & 3.37 & 0.24 & 3.13 \\
\hline L-005 & 39.48 & 21.67 & 17.81 & 0.930 & 2.652 & 28.600 & & 2.20 & 4.96 & 1.53 & 3.43 \\
\hline L-006 & 43.00 & 20.87 & 22.13 & 1.350 & 2.631 & 37.230 & 10.920 & 0.60 & 1.97 & 0.15 & 1.82 \\
\hline$L-007$ & 41.13 & 25.50 & 15.63 & 1.260 & 2.624 & & 16.620 & 0.90 & 4.54 & 2.36 & 2.18 \\
\hline L-008 & 41.76 & 24.97 & 16.79 & 1.150 & 2.653 & 26.490 & 27.460 & 2.50 & 6.00 & 0.70 & 5.30 \\
\hline L-009 & 42.26 & 27.40 & 14.86 & 2.065 & 2.642 & 25.935 & 15.430 & 9.05 & 6.38 & 0.30 & 6.08 \\
\hline L-010 & 45.30 & 25.39 & 19.91 & 2.330 & 2.621 & 23.030 & 19.470 & 10.00 & 6.17 & 1.80 & 4.37 \\
\hline$L-011$ & 43.68 & 25.39 & 18.29 & 0.780 & 2.698 & 32.240 & 7.460 & 4.60 & 5.14 & 0.86 & 4.28 \\
\hline $\mathrm{L}-012$ & 46.69 & 27.51 & 19.18 & 1.005 & 2.670 & 25.730 & & 2.30 & 6.04 & 0.60 & 5.44 \\
\hline L-013 & 48.87 & 29.24 & 19.63 & 1.050 & 2.639 & 27.720 & & 1.90 & 11.21 & 4.83 & 6.38 \\
\hline L-014 & 44.10 & 25.00 & 19.10 & 1.530 & 2.626 & 28.490 & 8.060 & 1.60 & 4.13 & 1.43 & 2.70 \\
\hline L-015 & 43.21 & 27.12 & 16.09 & 0.880 & 2.638 & 22.400 & & 1.10 & 4.41 & 1.86 & 2.55 \\
\hline L-016 & 41.02 & 24.72 & 16.30 & & & & & 1.10 & 4.59 & 1.16 & 3.43 \\
\hline L-017 & 47.85 & 25.73 & 22.12 & 2.470 & 2.517 & 38.170 & 3.010 & 0.50 & 1.41 & 0.14 & 1.27 \\
\hline $\mathrm{L}-018$ & 44.69 & 22.55 & 22.14 & 1.970 & 2.592 & 34.760 & & 0.70 & 2.28 & 0.12 & 2.16 \\
\hline L-019 & 42.37 & 23.95 & 18.42 & 1.320 & 2.634 & 24.790 & 11.300 & 0.70 & 4.01 & 0.64 & 3.37 \\
\hline $\mathrm{L}-020$ & 40.10 & 22.05 & 18.05 & 1.150 & 2.689 & 24.390 & & 1.20 & 3.61 & 0.47 & 3.14 \\
\hline $\mathrm{L}-021$ & 42.50 & 22.01 & 20.49 & 1.690 & 2.639 & 26.705 & 5.380 & 1.00 & 3.60 & 0.16 & 3.44 \\
\hline Average & 43.06 & 24.77 & 18.30 & 1.496 & 2.629 & 28.192 & 12.945 & 2.91 & 5.07 & 1.31 & 3.76 \\
\hline
\end{tabular}




\section{B. Dolomite}

\begin{tabular}{|c|c|c|c|c|c|c|c|c|c|c|c|}
\hline Id. No. & IFV & PV & WI & Absorption & Sp. Gravity & LA Abrasion & Sulfate & $\mathrm{Mg}(\%)$ & Insol (Total) & $>\# 200$ & $<\# 200$ \\
\hline $\mathrm{D}-001$ & 40.00 & 24.90 & 15.10 & 0.79 & 2.732 & 25.53 & 0.36 & 12.40 & 1.70 & 1.23 & 0.48 \\
\hline D-002 & 43.30 & 25.00 & 18.30 & 2.39 & 2.599 & 28.59 & & 12.90 & 0.71 & 0.02 & 0.69 \\
\hline $\mathrm{D}-003$ & 41.80 & 27.30 & 14.50 & 2.64 & 2.605 & 27.05 & 9.57 & 11.30 & 3.13 & 2.07 & 1.06 \\
\hline D-004 & 46.90 & 35.30 & 11.60 & 6.25 & 2.390 & 29.36 & 9.86 & 11.30 & 2.11 & 0.11 & 2.00 \\
\hline D-005 & 44.00 & 27.70 & 16.30 & 2.02 & 2.616 & 29.19 & 7.30 & 11.60 & 9.82 & 3.55 & 6.28 \\
\hline D-006 & 42.70 & 26.80 & 15.90 & 1.56 & 2.626 & 26.62 & 2.24 & 12.40 & 5.29 & 1.79 & 3.50 \\
\hline D-007 & 44.00 & 28.80 & 15.20 & 3.05 & 2.583 & 32.43 & 4.79 & 12.90 & 1.34 & 0.21 & 1.13 \\
\hline D-008 & 44.60 & 28.70 & 15.90 & 2.38 & 2.594 & 31.73 & 0.76 & 13.10 & 0.22 & 0.03 & 0.20 \\
\hline D-009 & 44,80 & 31.00 & 13,80 & 1.21 & 2.671 & 22.47 & 5.59 & 10.70 & 7.42 & 4.40 & 3.02 \\
\hline $\mathrm{D}-010$ & 45.90 & 31.30 & 14.60 & 3.76 & 2.489 & 36.98 & 3.29 & 12.60 & 4.16 & 1.81 & 2.35 \\
\hline D-011 & 46.20 & 30.00 & 16.20 & 2.02 & 2.632 & 24.75 & 5.99 & 12.20 & 6.31 & 2.71 & 3.59 \\
\hline D-012 & 47.60 & 31.30 & 16.30 & 2.74 & 2.588 & 29.50 & 2.24 & 11.90 & 7.65 & 3.39 & 4.26 \\
\hline D-013 & 43.50 & 32.70 & 10,80 & & & & & 10.10 & 5.56 & 0.78 & 4.78 \\
\hline D-014 & 46.70 & 32.00 & 14.70 & 4.00 & 2.480 & 30.28 & 13.18 & 11.20 & 5.27 & 0.71 & 4.55 \\
\hline D-015 & 40.50 & 24.10 & 16.40 & 1.03 & 2.669 & 29.76 & 2.56 & 12.80 & 0.50 & 0.27 & 0.22 \\
\hline D-016 & 40.10 & 23.60 & 16.50 & 1.86 & 2.614 & 32.62 & 0.55 & -12.90 & 0.08 & 0.02 & 0.06 \\
\hline D-017 & 41,30 & 24.90 & 16.40 & 1.00 & 2.718 & 25.69 & 0.31 & 12.90 & 0.35 & 0.03 & 0.32 \\
\hline D-018 & 43.60 & 28.40 & 15.20 & 2.48 & 2.619 & 27.25 & 3.62 & & 2.15 & 0.94 & 1.21 \\
\hline D-019 & 41.60 & 28.00 & 13.60 & 1.59 & 2.648 & 30.75 & 6.45 & & 6.66 & 4.45 & 2.21 \\
\hline D-020 & 41.90 & 28.10 & 13.80 & 2.95 & 2.590 & 28.54 & 5.33 & & 5.90 & 3.14 & 2.76 \\
\hline verage & 43.55 & 28.50 & 15.06 & 2.41 & 2.60 & 28.90 & 4.67 & 12.07 & 3.82 & 1.58 & 2.23 \\
\hline
\end{tabular}




\subsubsection{Aggregate Lithology and Friction Resistance Properties}

Friction resistance and other aggregate properties for limestone and dolomite samples are listed in Table 5-6. In order to determine how a specific geological formation relates to fictional properties, aggregate sources sampled from only one geological formation were used in the correlation analysis. The IFV and PV for each geological formation are shown in Table 5-7.

The Wabash Formation is divided into four members these being the Kenneth, Kokomo, Mississinewa and Huntington. Of the samples obtained from the Wabash Formation, L004 and D016 were excluded from consideration because these two samples were so difficult to assign to specific rock members.

As shown in Table 5-7, for the dolomite aggregates, the Kokomo Member (Upper Silurian) shows the highest PV (average 33.3) and the Huntington Dolomite (Upper Silurian) shows the lowest PV (average 25.6). For the limestone aggregates, Mississinewa Member (Upper Silurian) shows the highest PV (28.1) and Brassfield Limestone (Lower Silurian) shows the lowest PV (20.9).

In order to determine the factors affecting the frictional properties of dolomite and limestone aggregates, elemental magnesium content and acid insoluble residue value for the geological formations were determined. This was because INDOT currently uses the elemental magnesium content analysis as the acceptance criteria for dolomite sources with the minimum level set at $10.3 \%$. Also impure dolomite and impure limestone have been known to be quality aggregate sources.

Elemental magnesium contents and acid insoluble residues for the various geological formations are provided in Table 5-8.

As presented in Table 5-8, considering elemental Mg content, for dolomite aggregates, Louisville Limestone (Middle Silurian) shows the highest elemental Mg content $(13.1 \%)$ and the Kokomo Member, which has the highest PV, shows the lowest elemental $\mathrm{Mg}$ content (10.9\%). 
Table 5-7. Friction resistance properties of carbonate aggregate samples.

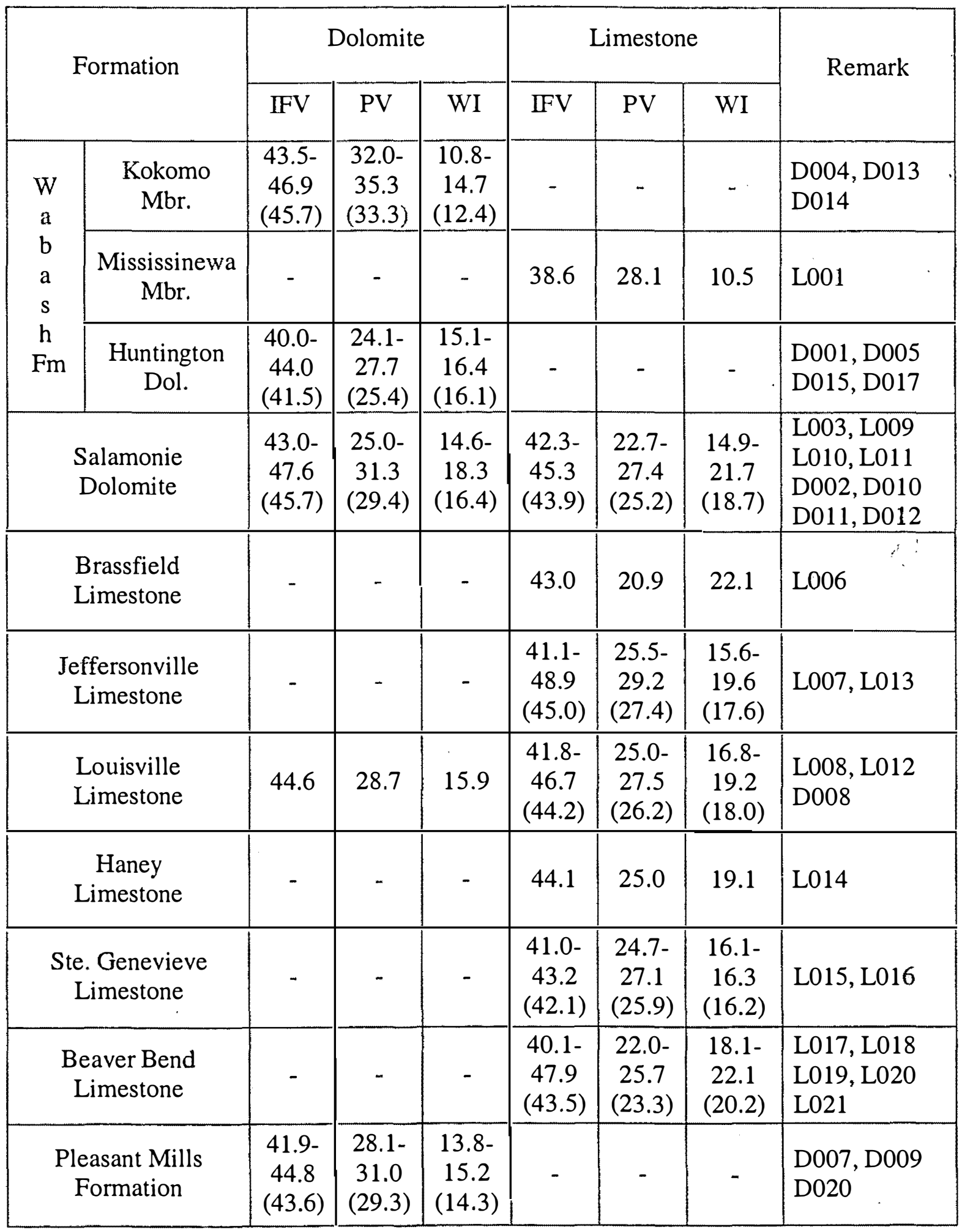


For limestone aggregates, Salamonie Dolomite (Lower Silurian) shows the highest elemental Mg content (8.29\%) and Brassfield Limestone with the lowest PV shows the lowest elemental $\mathrm{Mg}$ content (.0.6\%).

It is important to consider the following:

For dolomite aggregates:

- The lower the elemental Mg content, the more impure is the dolomite

- The lower the elemental Mg content, the higher is the PV (Figure 5-7).

higher the elemental $\mathrm{Mg}$ content, the more impure is the limestone - The higher the elemental Mg content, the higher is the PV (Figure 5-8).

Considering acid insoluble residue, for dolomite aggregates, the Pleasant Mills Formation (Middle Silurian) has the highest acid insoluble residue (4.89\%) and Louisville Limestone (Middle Silurian) has the lowest insoluble residue (0.22\%).

For limestone aggregates, the Mississinewa Member (Upper Silurian) has the highest PV but also indicates the highest insoluble residue (12.72\%). Brassfield Limestone (Lower Silurian) has the lowest PV and also has the lowest insoluble residue $(1.97 \%)$.

It is also important to consider that:

For both dolomite and limestone aggregates:

- The higher the acid insoluble residue (fine quartz and clay), the more impure are the dolomites and limestones

- The higher the acid insoluble residue, the higher the PV (Figures 5-9 and 5-10). As shown in Figures 5-9 and 5-10, for the dolomite case, the PV is correlated more highly with elemental $\mathrm{Mg}$ content $\left(\mathrm{R}=0.707, \mathrm{R}^{2}=0.50\right)$ than is the acid insoluble residue $(\mathrm{R}=0.318)$. Unlike dolomite, in the case of limestone, $\mathrm{PV}$ is more highly correlated with acid insoluble residue $\left(R=0.853, R^{2}=0.73\right)$ than with elemental $\mathrm{Mg}$ content $\left(R=0.376, R^{2}=0.14\right)$. 
Table 5-8. Elemental Mg content of carbonate aggregate samples.

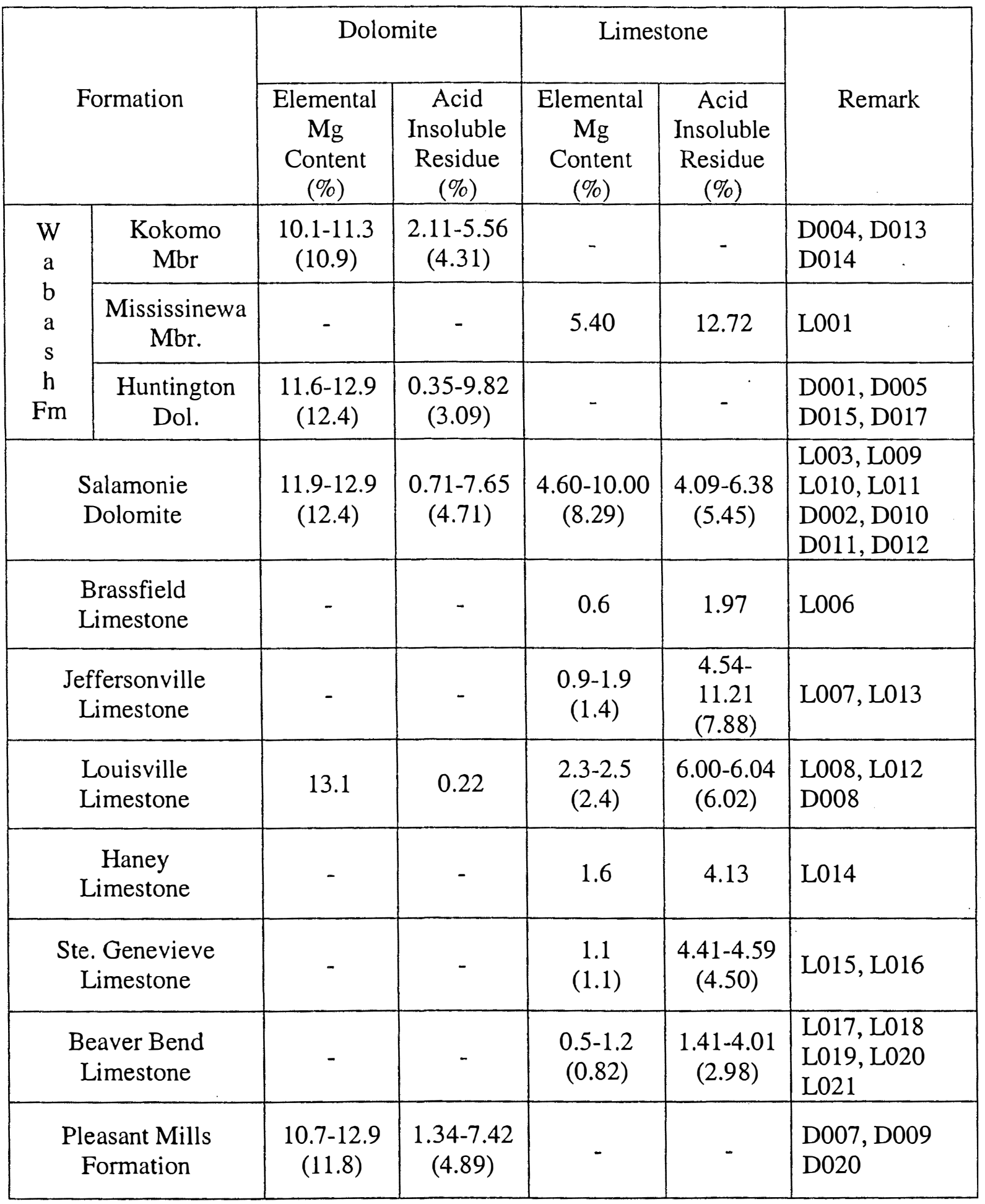




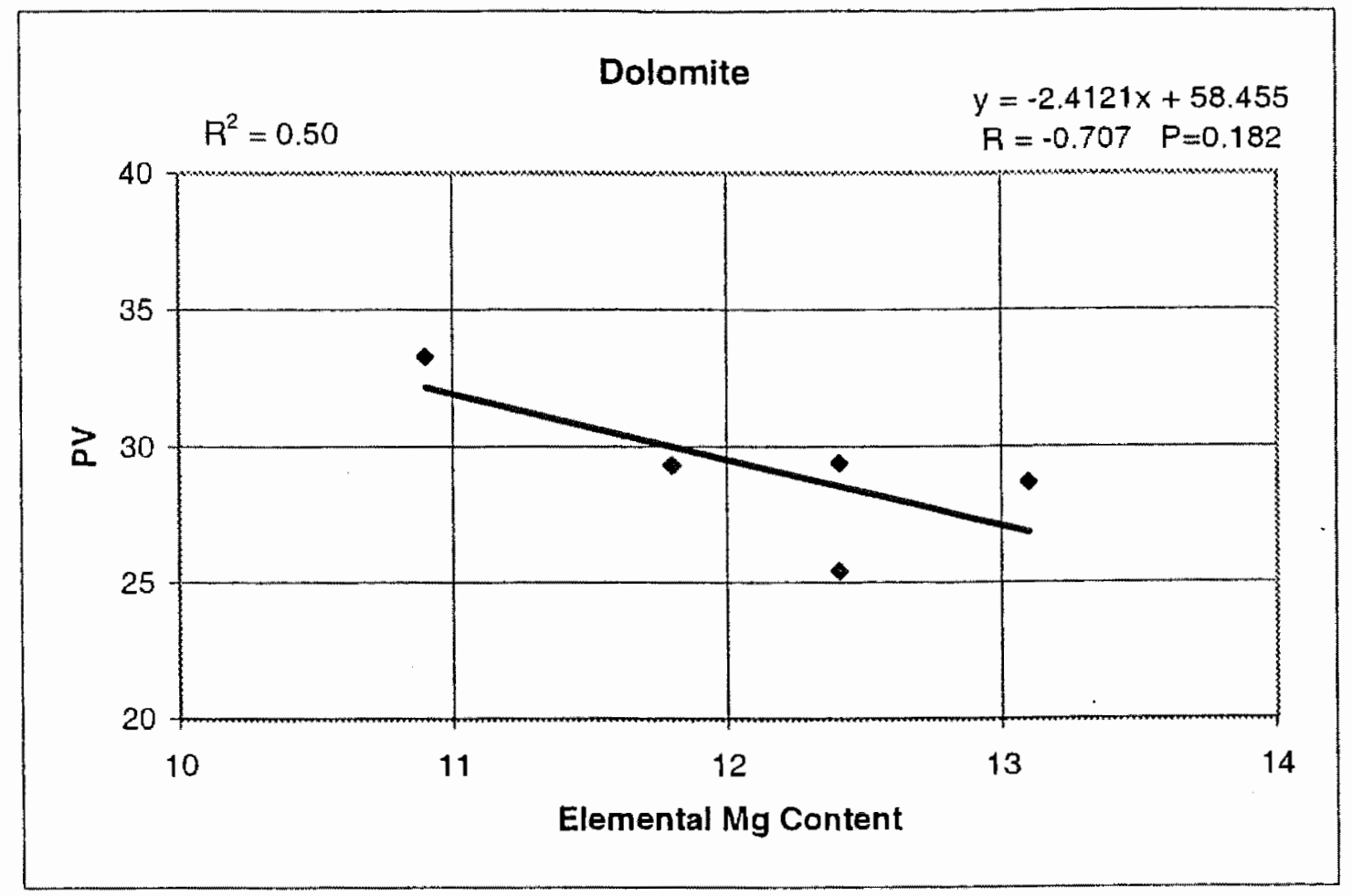

Figure 5-7. Elemental Mg content of dolomite samples

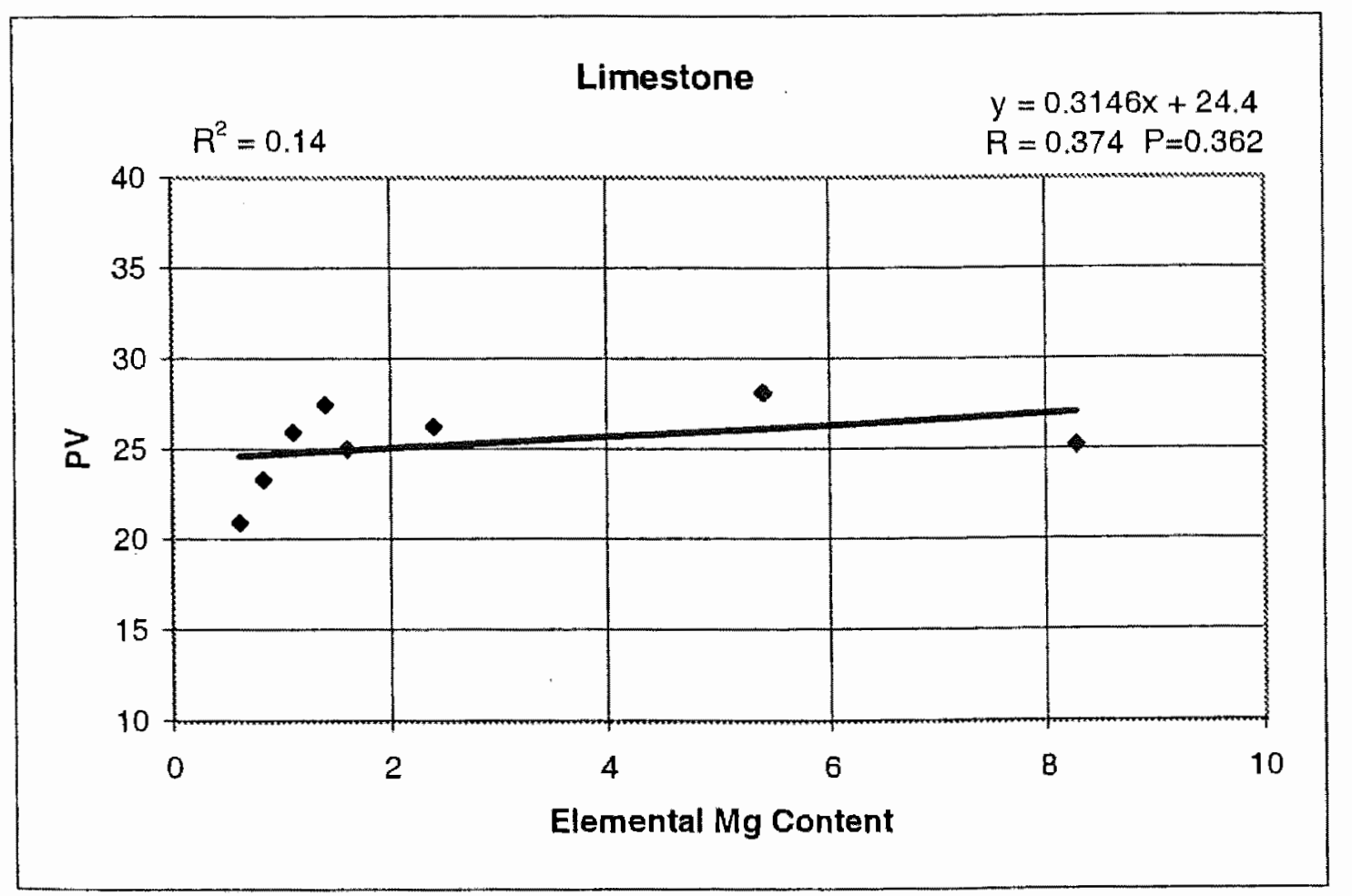

Figure 5-8. Elemental Mg content of limestone samples 


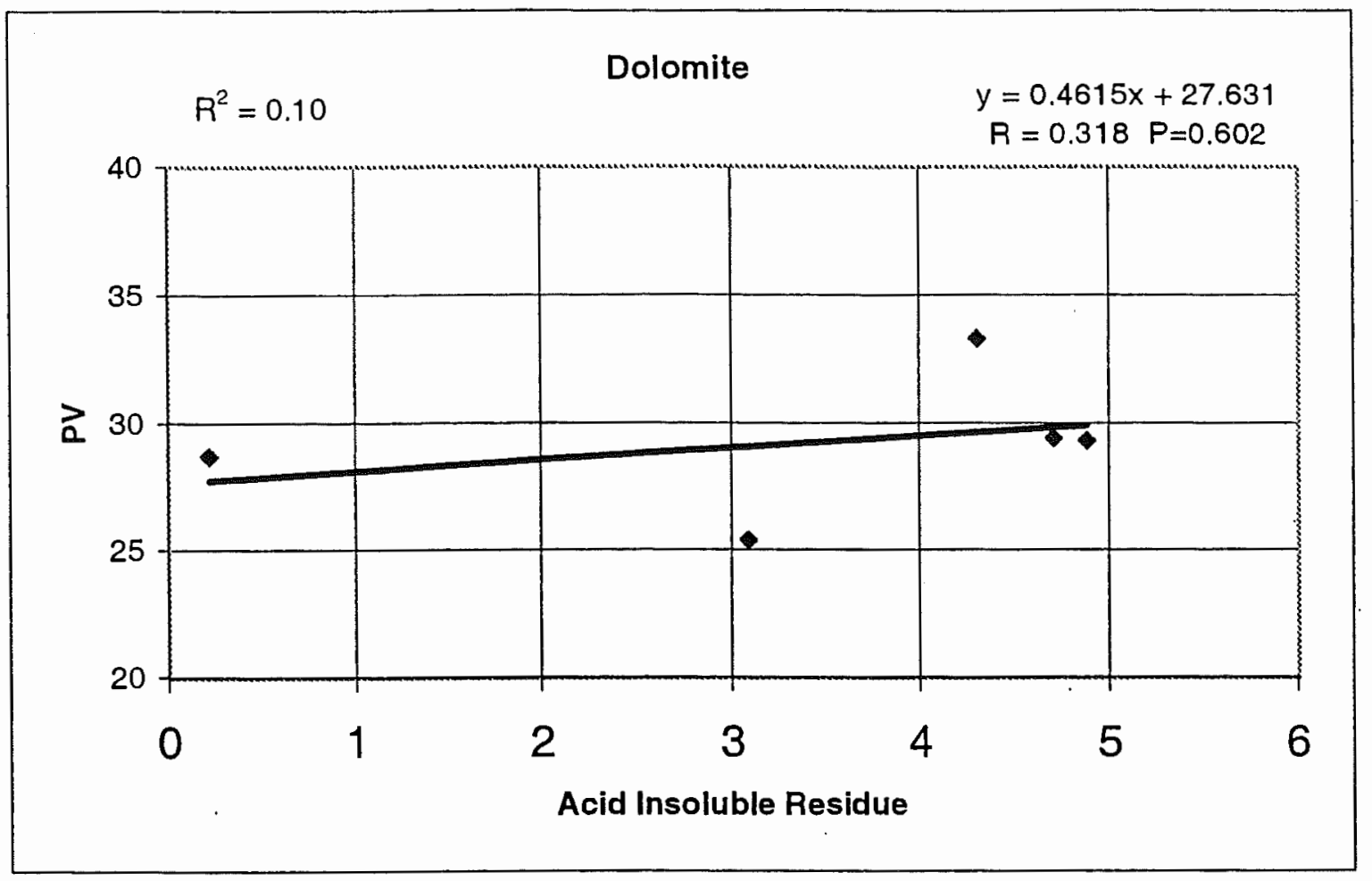

Figure 5-9. Acid insoluble residue of dolomite samples

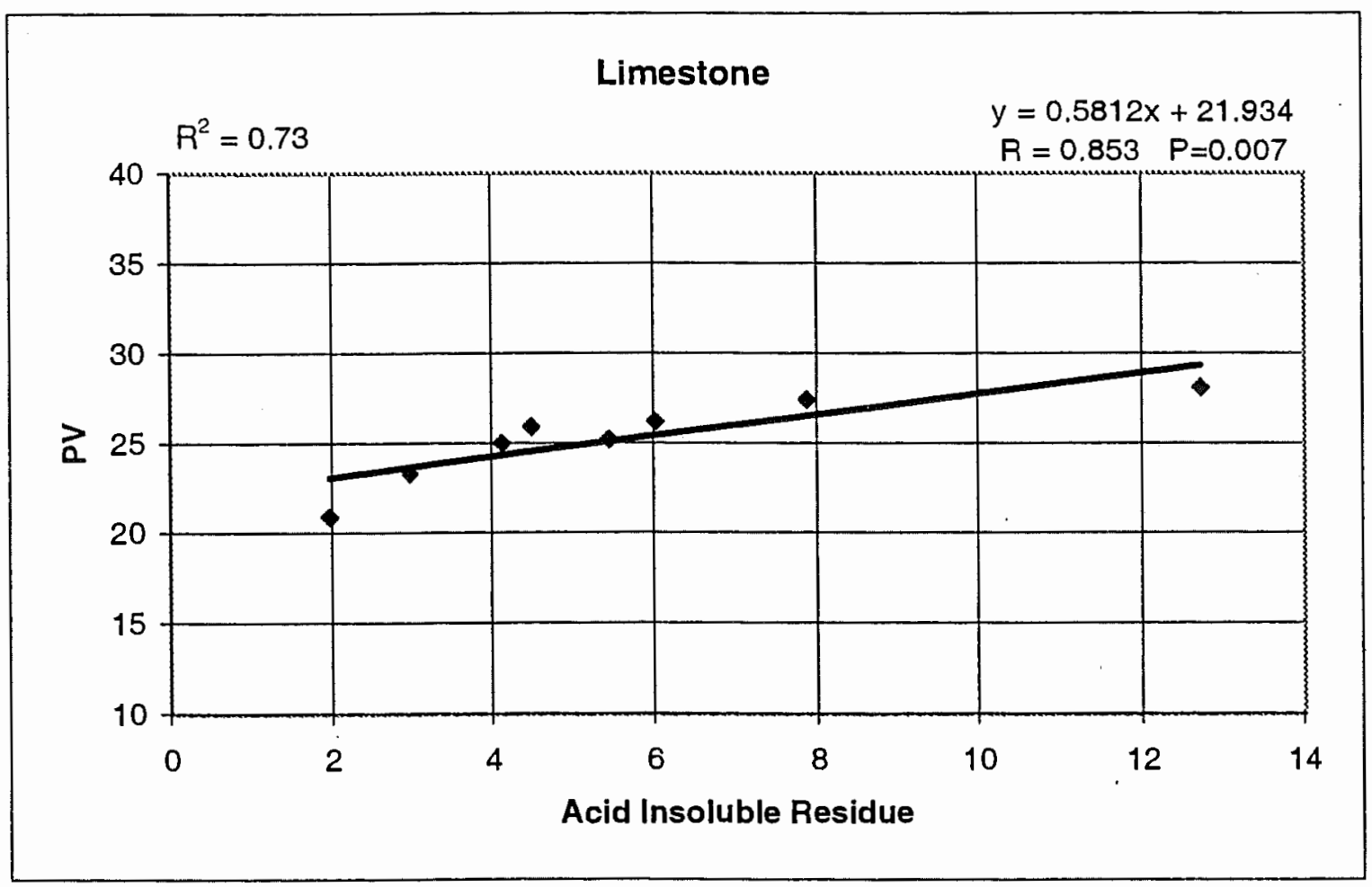

Figure 5-10. Acid insoluble residue of limestone samples 


\subsubsection{Physical and Frictional Resistance Properties of Carbonate Aggregates}

Data on the physical properties for representative samples of dolomite and limestone were obtained from INDOT.

For the dolomite study (Bruner, Choi and West, 1995), sulfate soundness results were used for correlation with frictional properties but in the subsequent limestone study, freeze-thaw data were used as a replacement for sulfate soundness data. In the time between the two studies, INDOT changed its standard testing from the sodium sulfate to the freeze and thaw test.

Among the physical tests, specific gravity, absorption and sodium sulfate soundness, correlated best with the PV and WI for dolomite. However, for limestone only freeze-thaw correlated with WI. Los Angeles abrasion did not correlate with IFV or PV at a significant probability level for either dolomite or limestone. The physical tests are summarized in Table 5-6.

\subsubsection{Specific Gravity}

Specific gravity can be considered as a measure of mineral purity of a sample. As a consequence of large amounts of impurities, the specific gravity will be reduced from that of a more pure sample. As mentioned in a previous section, the more impure samples provided greater polish resistance. The specific gravity for dolomites generally ranges from 2.86 to 3.10 . Dolomites in the previous study ranged from 2.390 to 2.732 , with an average of 2.60. Specific gravity for limestones generally ranges from 2.71 to 2.83. Limestone in this study ranged from 2.519 to 2.698 with an average of 2.63 .

As can be observed in Figures 5-11 and 5.12, for dolomite, PV decreases with increasing specific gravity $\left(R=-0.745, R^{2}=0.56\right.$ and $\left.P=0.000\right)$ and WI increases with increasing specific gravity $\left(R=0.462, R^{2}=0.21\right.$ and $\left.P=0.046\right)$. Therefore, $P V$ is increased for samples with a lower specific gravity, thus indicating greater polish resistance with increasing impurity and decreasing specific gravity.

As shown in Figures 5-13 and 5-14, for limestone samples, PV and WI do not correlate with the specific gravity, having $R=-0.073$ and $P=0.761$ for $P V$ and $R=-0,127$ and $\mathrm{P}=0.593$ for WI. 


\subsubsection{Absorption}

Materials with a high absorptive capacity are generally weaker aggregates. However, regarding frictional resistance, a weaker fraction yields a rougher surface during polishing. For dolomites, as absorptive capacity increases, $P V$ increases $(R=0.765$, $\mathrm{R}^{2}=0.59$ and $\left.\mathrm{P}=0.000\right)$ and $\mathrm{WI}$ decreases $\left(\mathrm{R}=-0.538, \mathrm{R}^{2}=0.29\right.$ and $\left.\mathrm{P}=0.018\right)$ as shown in Figures 5-15 and 5-16.

For limestones, PV and WI do not correlate with absorption as indicated in Figures 5-17 and 5-18. For dolomite, the presence of weaker material aids in the reduction of the polishing effect. This is because the weaker materials easily absorb water and increase micro-texture on aggregate surface causing an increase in PV. However, this phenomenon is not significant for the limestone samples.

\subsubsection{Sodium Sulfate Soundness}

This test is a measure of aggregate durability and is related to absorption. As shown in Figures 5-19 and Figure 5-20, for dolomites, as sulfate soundness loss increases, $P V$ increases $\left(R=0.603, R^{2}=0.36\right.$ and $\left.P=0.008\right)$ and $W I$ decreases $(R=-0.567$, $\mathrm{R}^{2}=0.32$ and $\mathrm{P}=0.014$ ).

For limestones, the sulfate soundness loss data were too few in number to provide a meaningful analysis. Therefore, freeze-thaw data were used for the comparison with PV and WI instead of with sulfate soundness data.

\subsubsection{Freeze and Thaw Loss}

In the Indiana specification, 50 cycles of freezing and thawing can be used for aggregate verification instead of the sodium sulfate soundness test. For the limestone aggregate study freeze and thaw loss results were used instead of those for the sulfate soundness test.

As shown in Figures 5-21 and 5-22, PV of the limestone samples does not correlate well with freeze and thaw loss $\left(\mathrm{R}=0.286, \mathrm{R}^{2}=0.08\right.$ and $\left.\mathrm{P}=0.367\right)$. However, WI 
decreases as the freeze and thaw loss increases $\left(R=-0.653, R^{2}=0.34\right.$ and $\left.P=0.021\right)$ indicating a lower polishing susceptibility with higher freeze and thaw loss.

\subsubsection{Los Angeles Abrasion Loss}

As shown in Figures 5-23 and 5-24, the PV and WI of the dolomite samples do not correlate well with freeze and thaw loss, having $R=0.107$ and $P=0.662$ for $P V$ and $R=-0.008$ and $P=0.973$. The $P V$ and WI of the limestone samples in Figures 5-25 and 526 do not correlate well with the freeze and thaw loss, having $R=-0.210, \quad=0.04$ and $\mathrm{P}=0.388$ for $\mathrm{PV}$ and $\mathrm{R}=0.359, \mathrm{R}^{2}=0.13$ and $\mathrm{P}=0.131$ for $\mathrm{WI}$.

\subsubsection{Magnesium Content and Frictional Properties of Carbonate Aggregates}

Data acquired from the magnesium analysis, based on 17 samples for dolomites and 21 samples for limestone, were analyzed to find the relationship between elemental $\mathrm{Mg}$ content and frictional resistance. The elemental magnesium contents range from $10.1 \%$ to $13.1 \%$ for the dolomite samples and $0.5 \%$ to $10 \%$ for the limestone samples.

As shown in Figures 5-27 and 5-28, for dolomites, elemental $\mathrm{Mg}$ contents correlate with PV $\left(R=-0.653, R^{2}=0.43\right.$ and $\left.P=0.005\right)$ and $W I\left(R=0.756, R^{2}=0.57\right.$ and $\mathrm{P}=0.000$ ). This indicates that purer dolomites with higher elemental $\mathrm{Mg}$ values show lower PV and higher WI. Therefore, impure dolomite (lower elemental Mg content) is a potentially acceptable aggregate for bituminous surface pavements.

As shown in Figures 5-29 and 5-30, for limestone samples, elemental $\mathrm{Mg}$ contents do not correlate with either $P V\left(R=0.205, R^{2}=0.04\right.$ and $\left.P=0.373\right)$ or $W I(R=-0.109$, $\mathrm{R}^{2}=0.01$ and $\mathrm{P}=0.639$ ). 


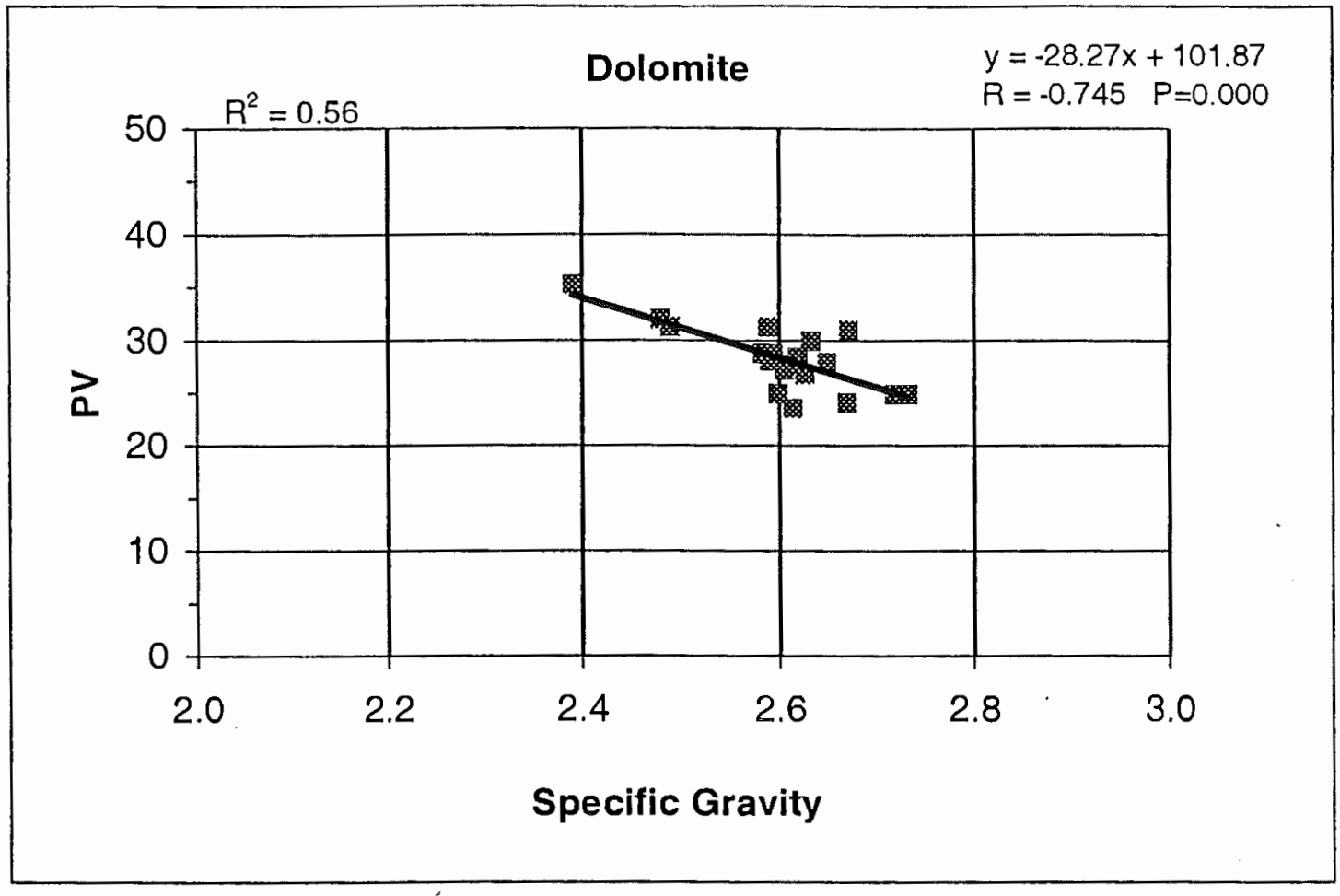

Figure 5-11. Correlation of Polished Value and Specific Gravity in dolomite samples

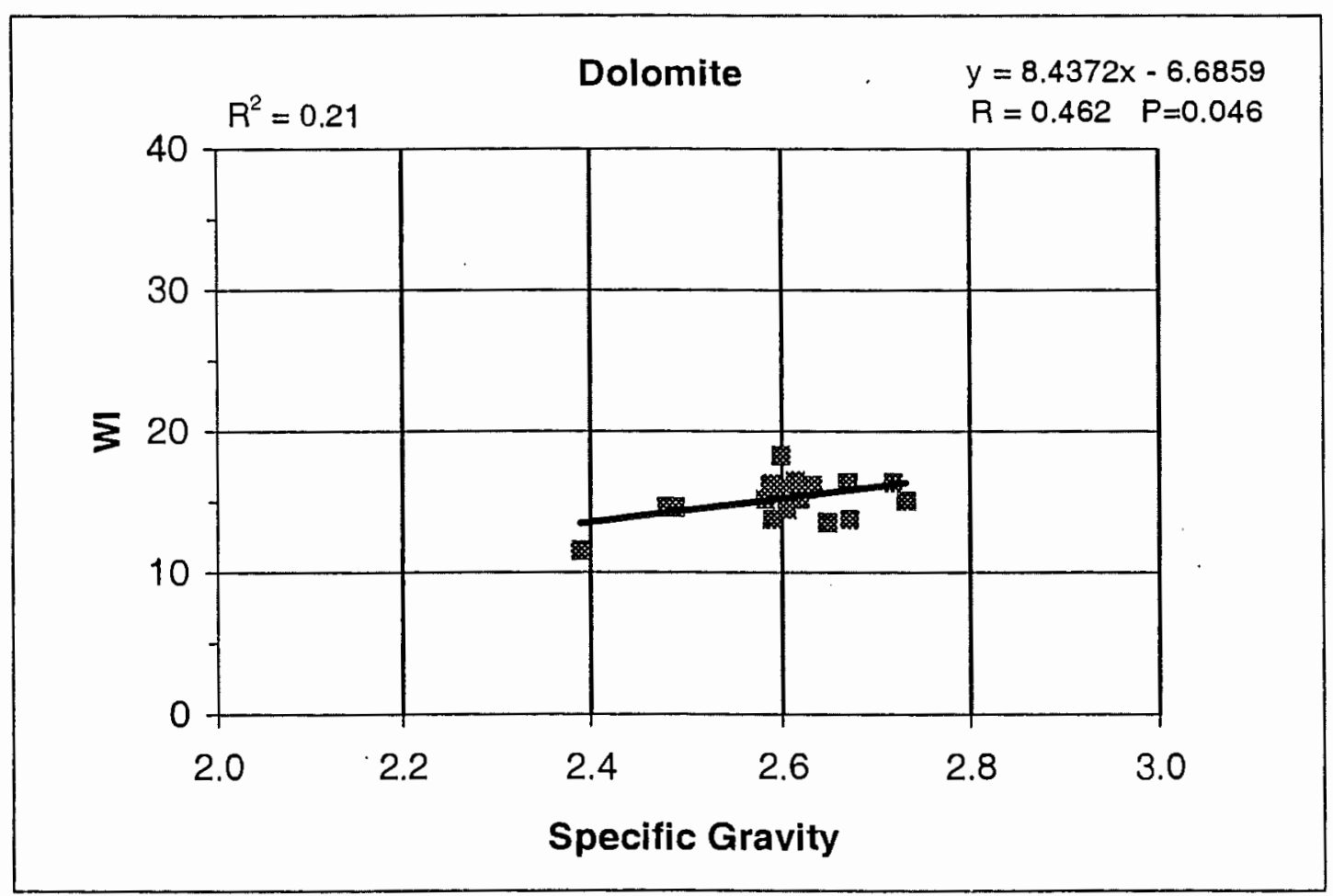

Figure 5-12. Correlation of Wear Index and Specific Gravity in dolomite samples 


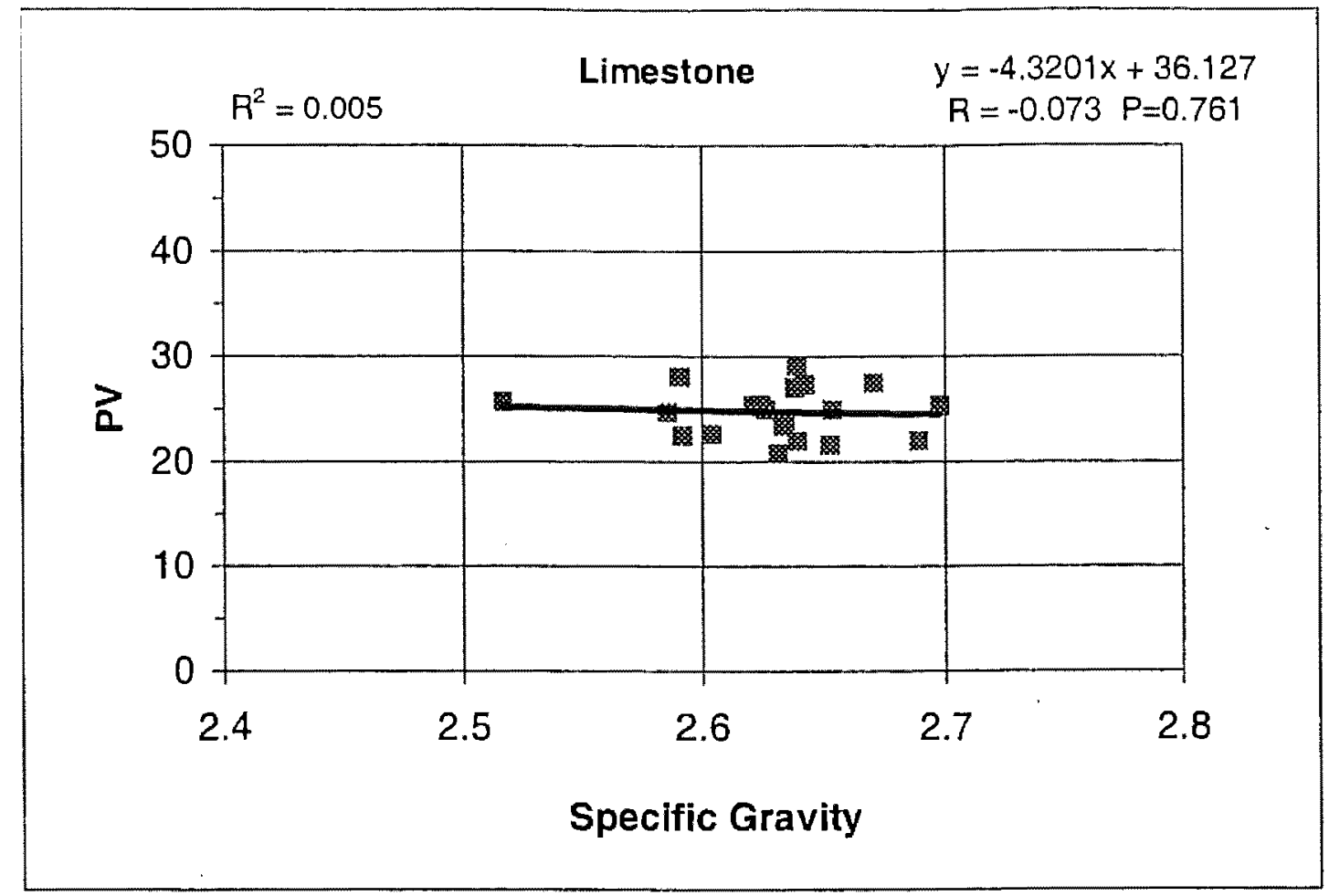

Figure 5-13. Correlation of Polished Value and Specific Gravity in limestone samples

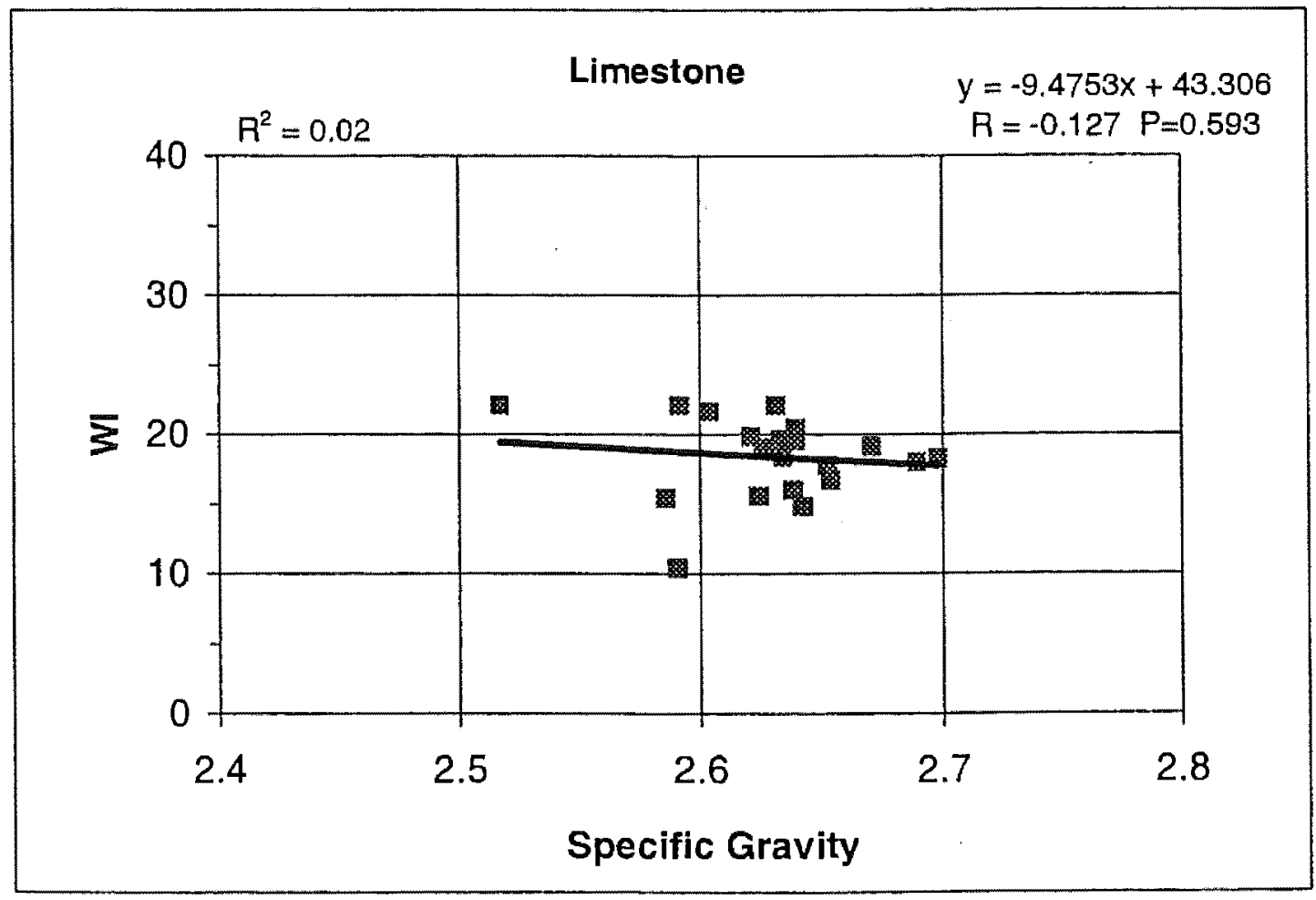

Figure 5-14. Correlation of Wear Index and Specific Gravity in limestone samples 


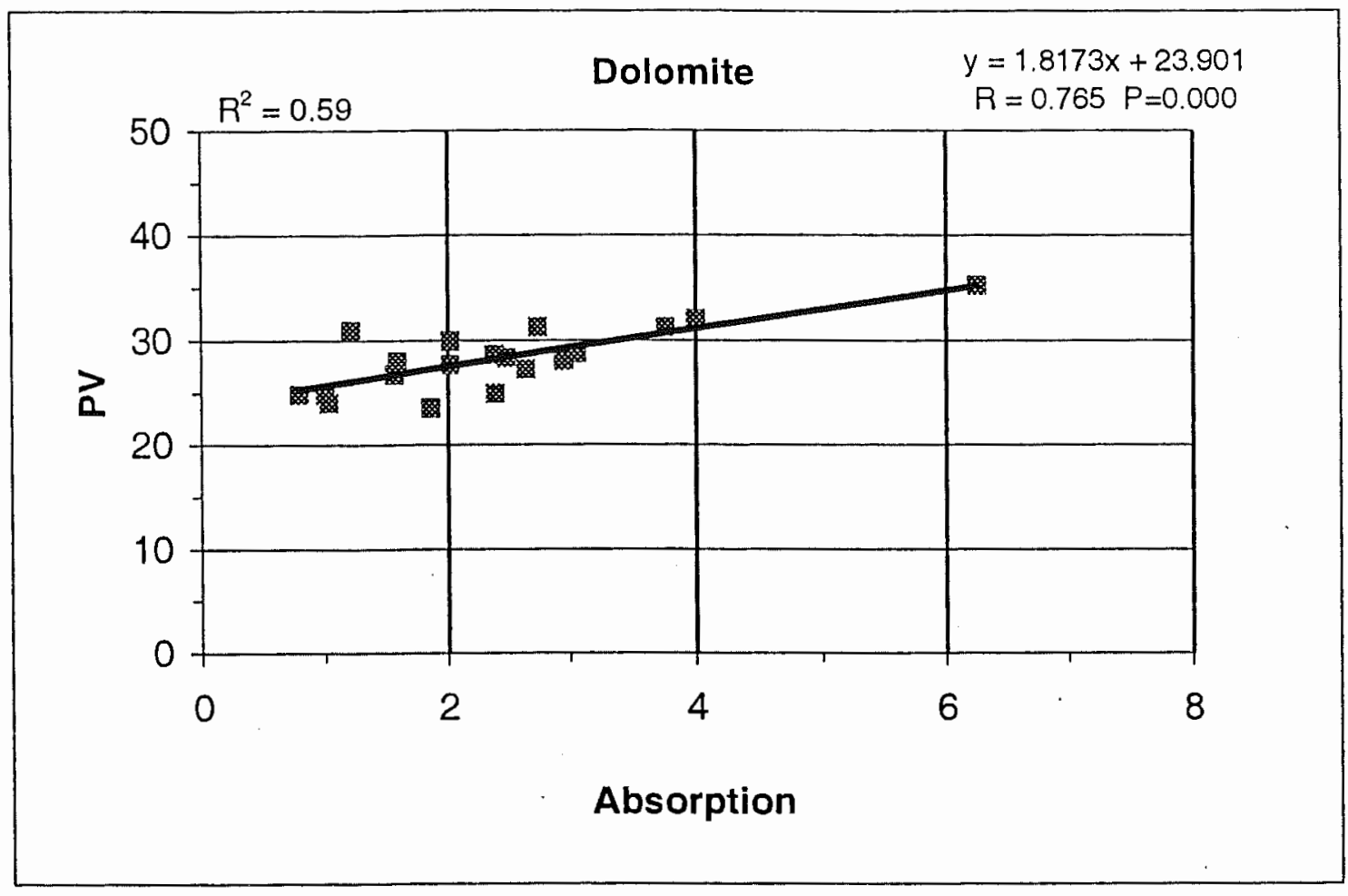

Figure 5-15. Correlation of Polished Value and Absorption in dolomite samples

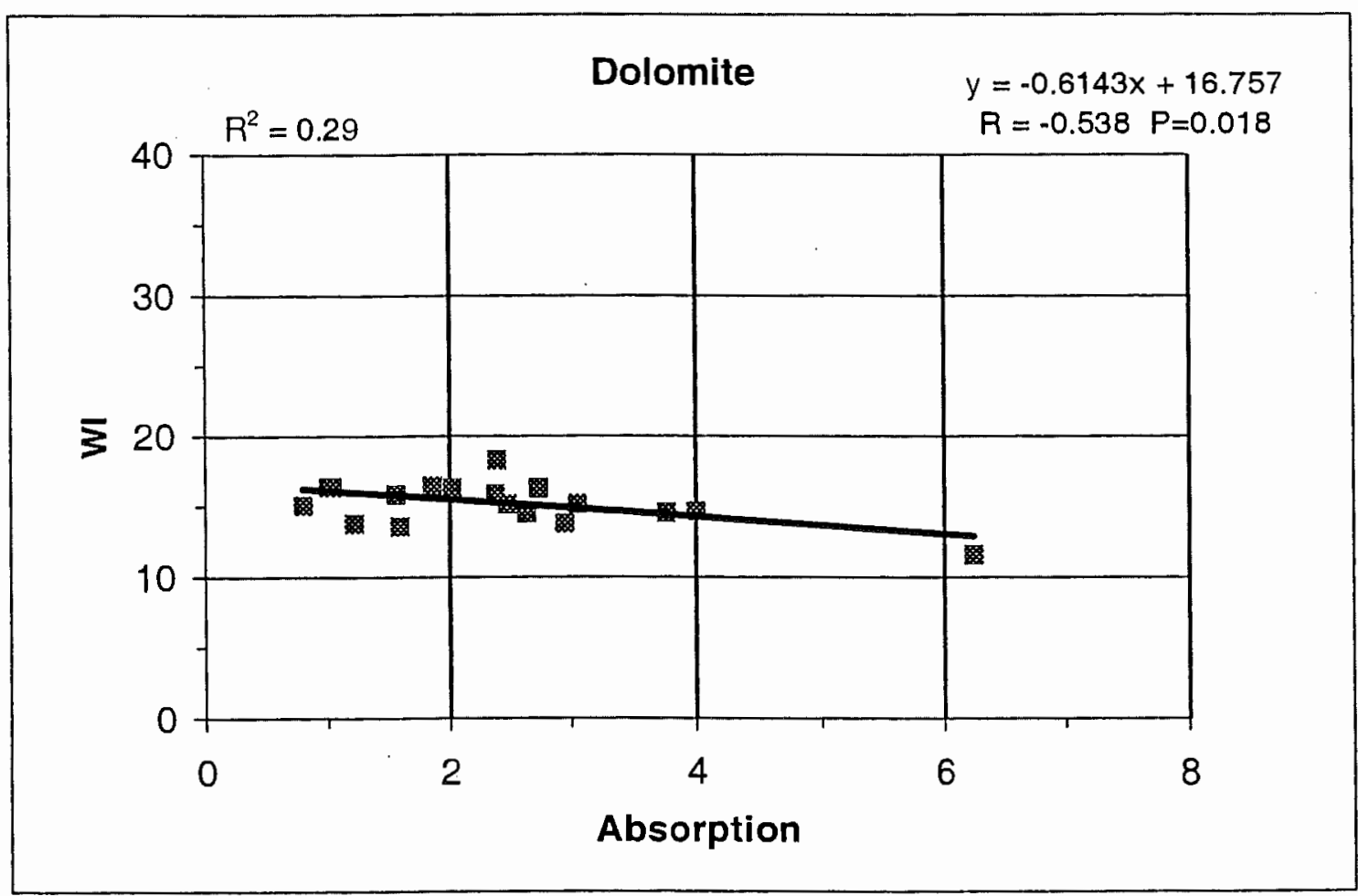

Figure 5-16. Correlation of Wear Index and Absorption in dolomite samples 


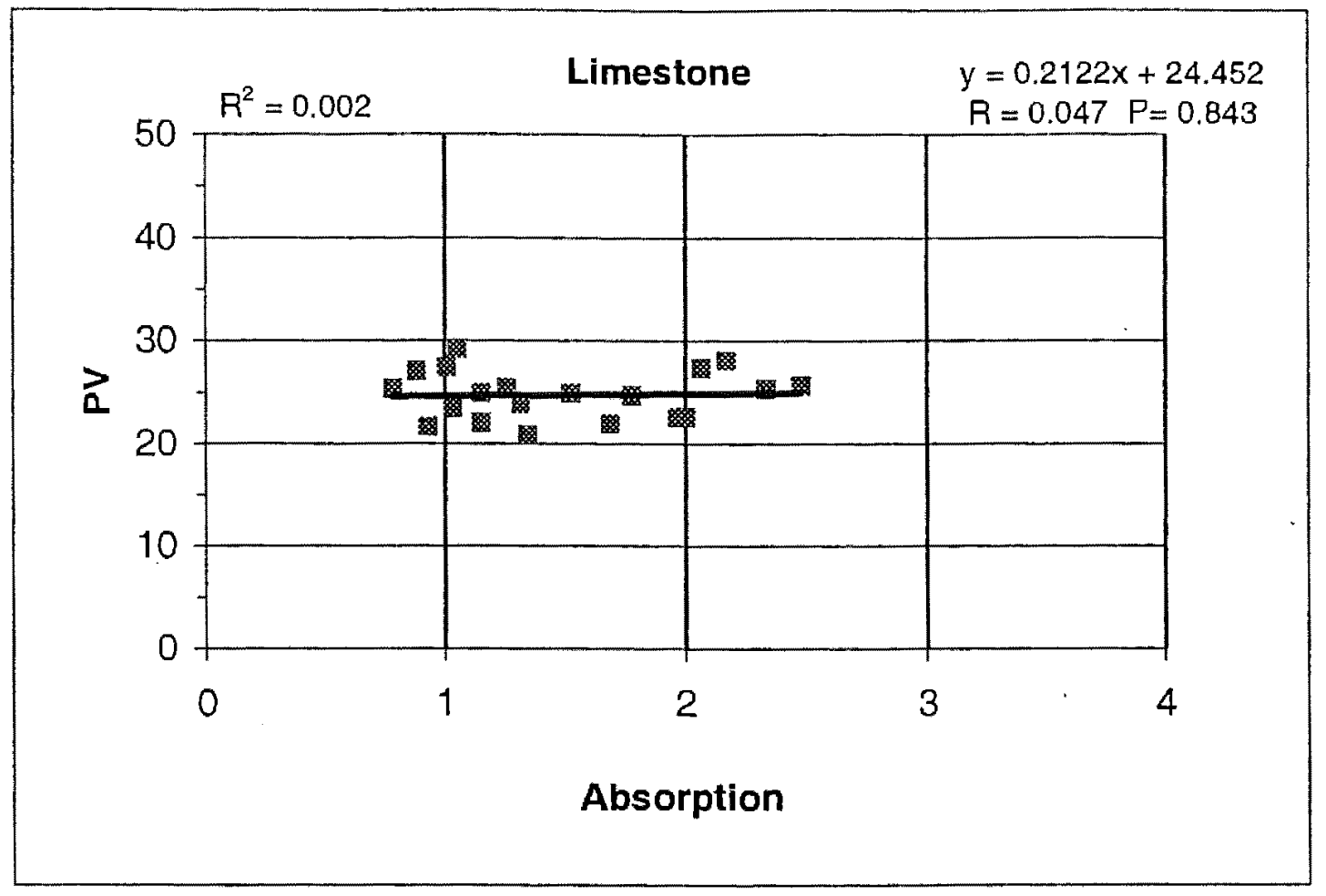

Figure 5-17. Correlation of Polished Value and Absorption in limestone samples

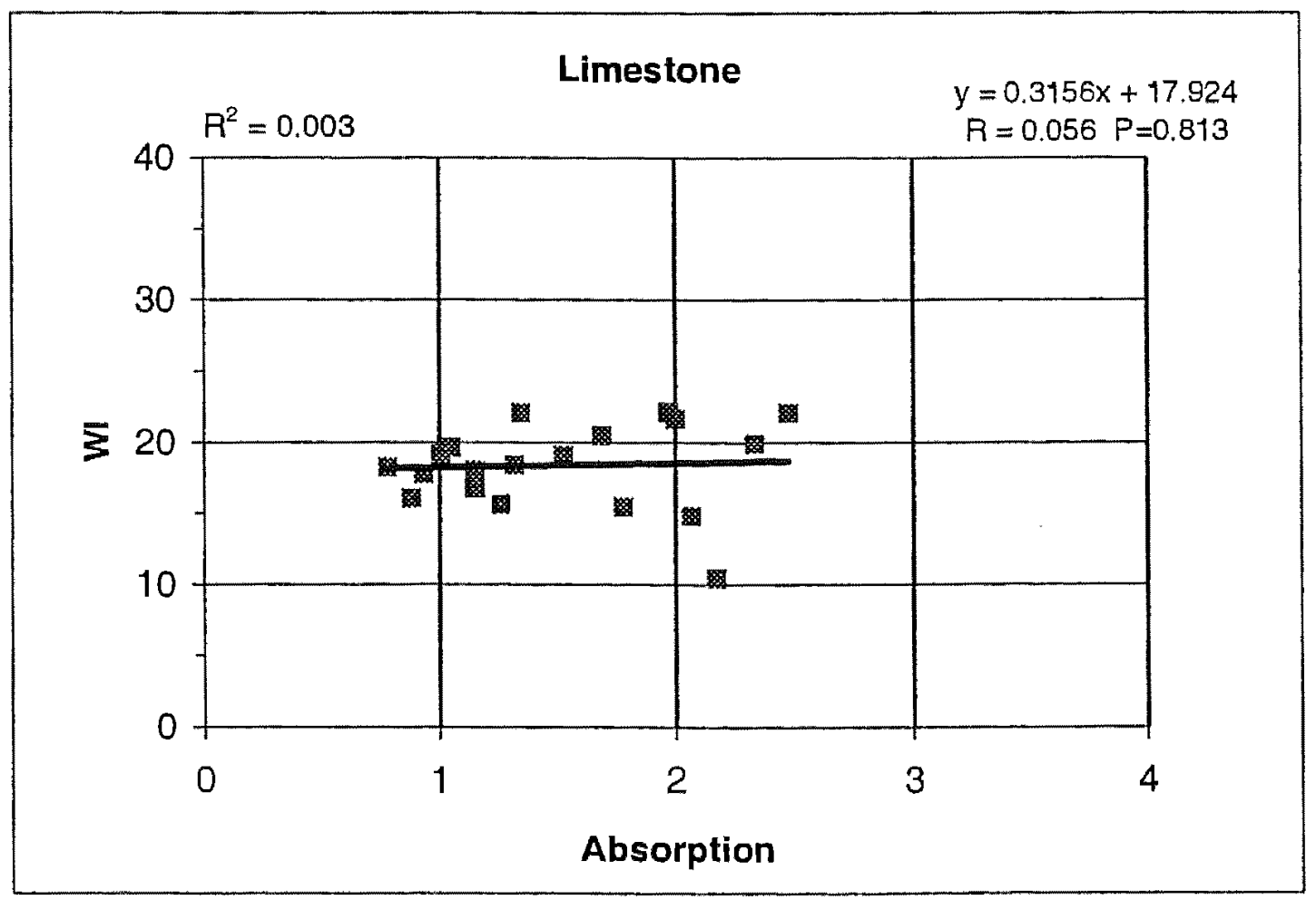

Figure 5-18. Correlation of Wear Index and Absorption in limestone samples 


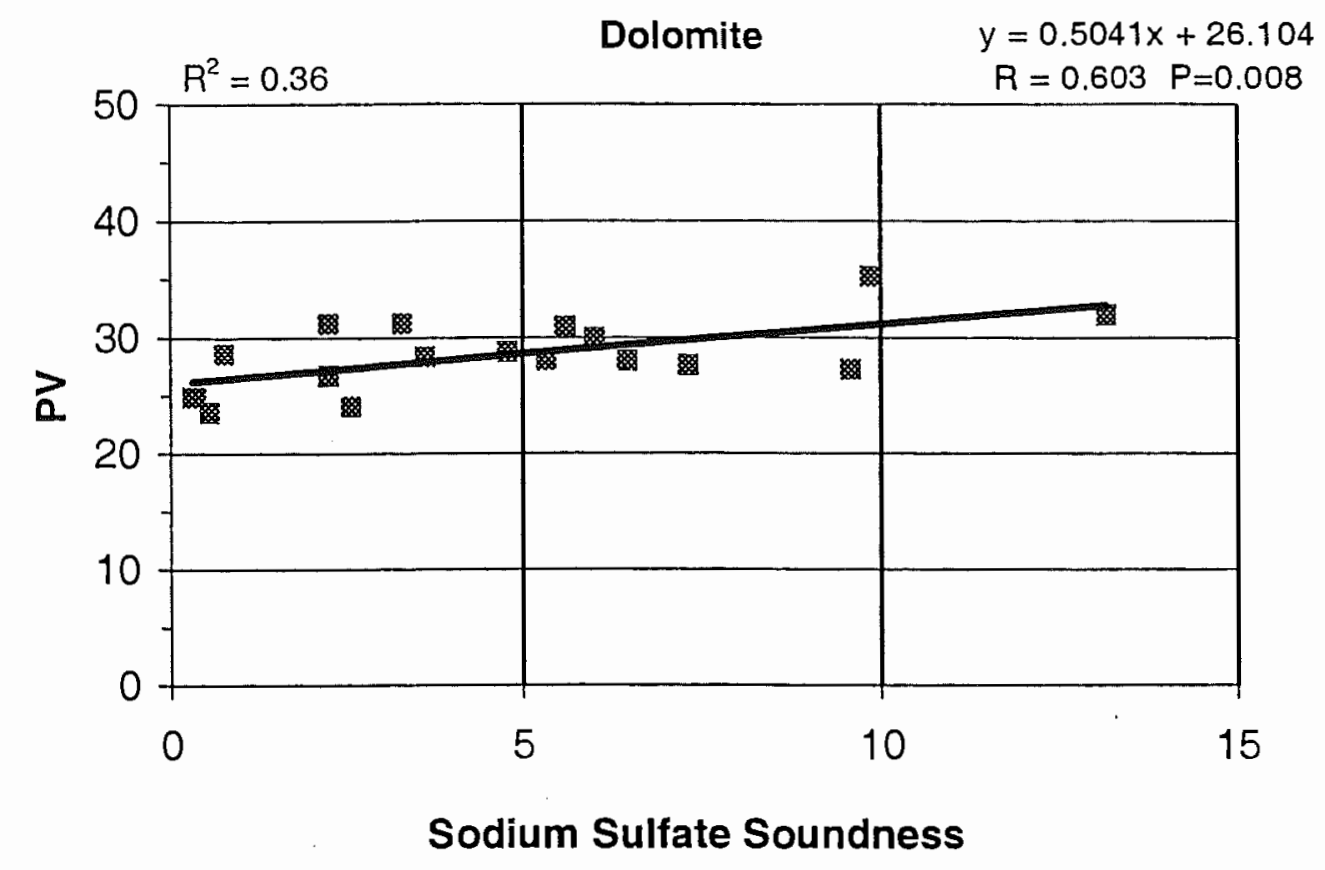

Figure 5-19. Correlation of Polished Value and Sodium sulfate soundness in dolomite samples

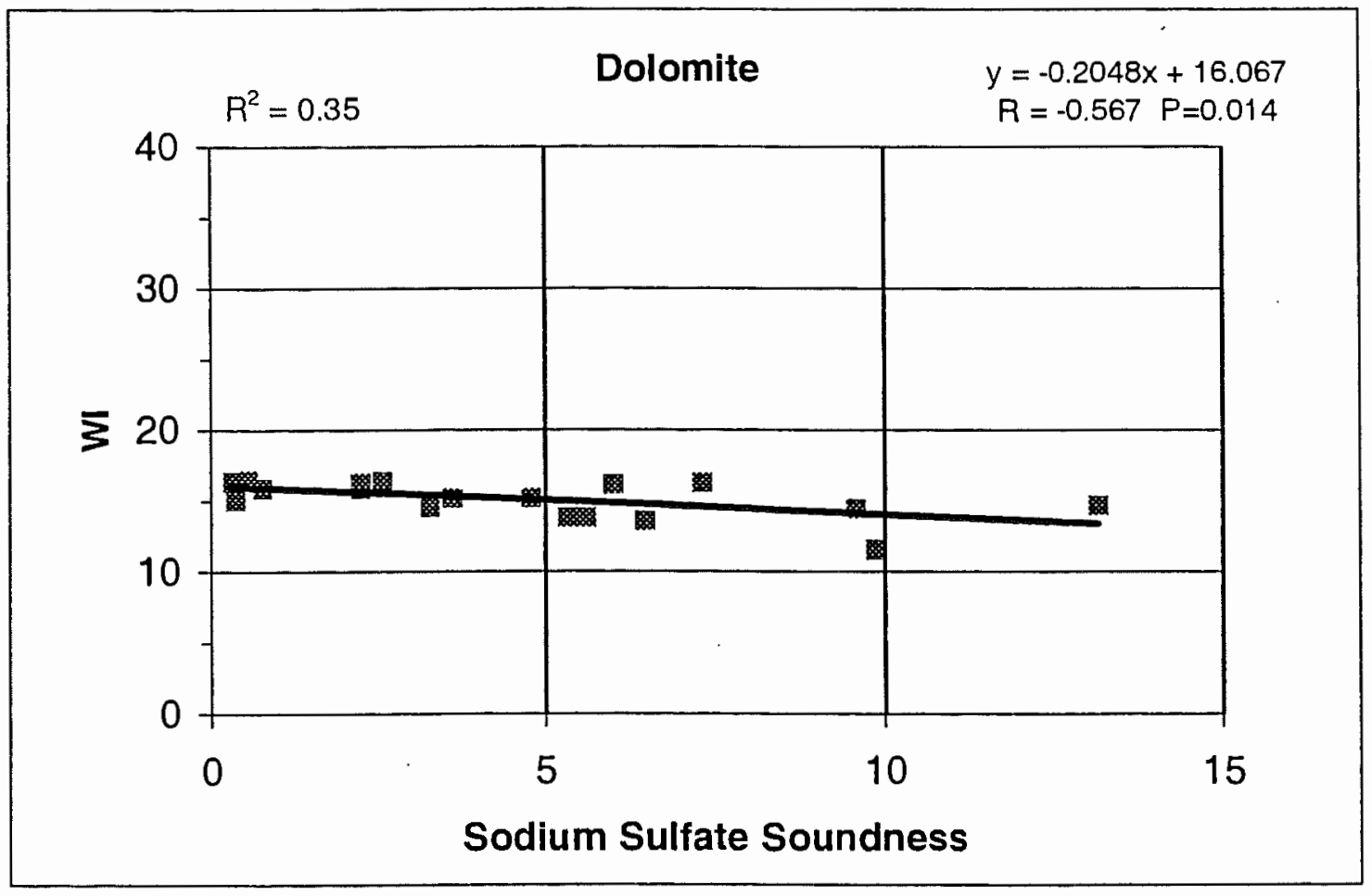

Figure 5-20. Correlation of Wear Index and Sodium sulfate soundness in dolomite samples 


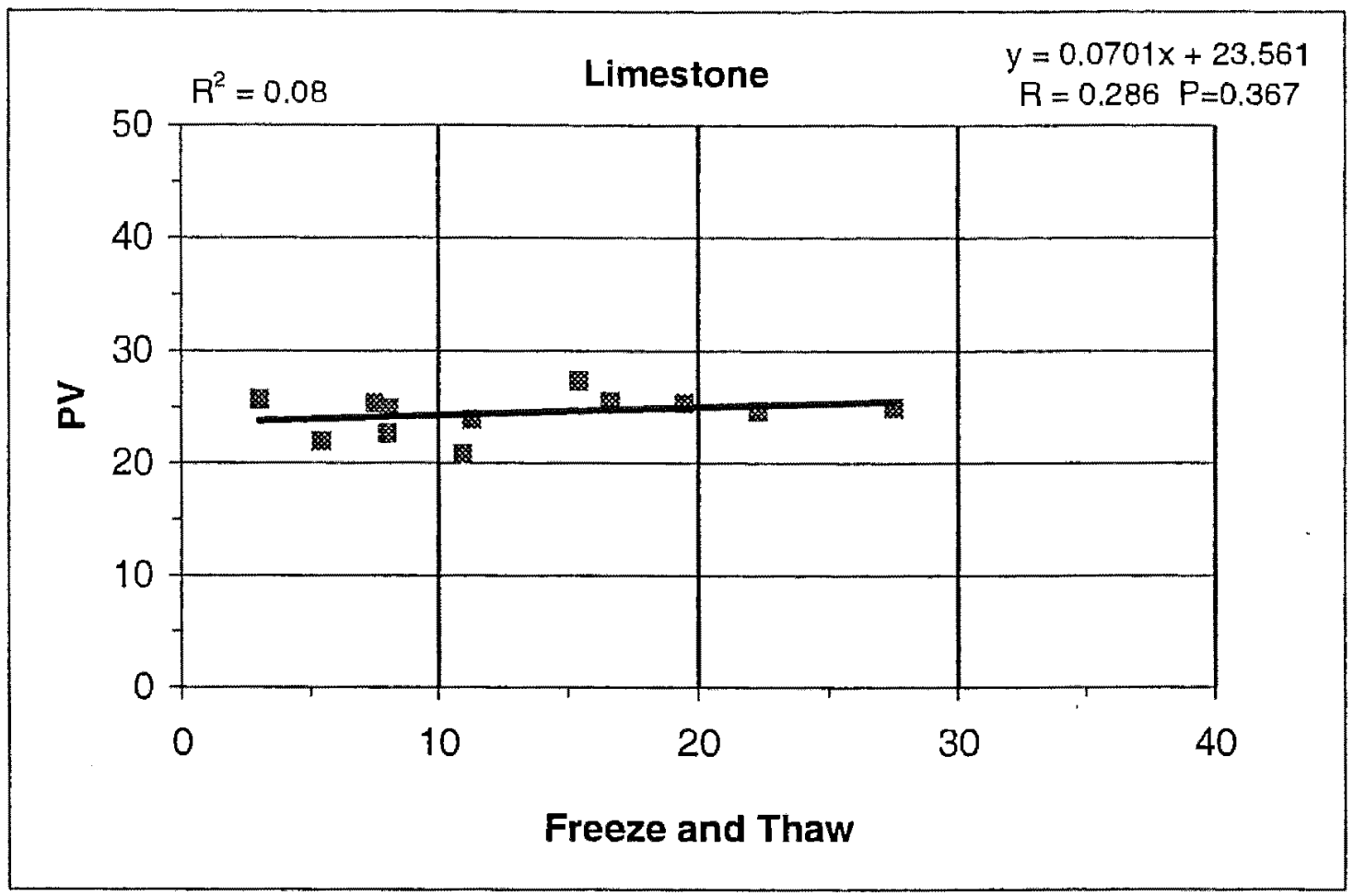

Figure 5-21. Correlation of Polished Value and Sodium sulfate soundness in limestone samples

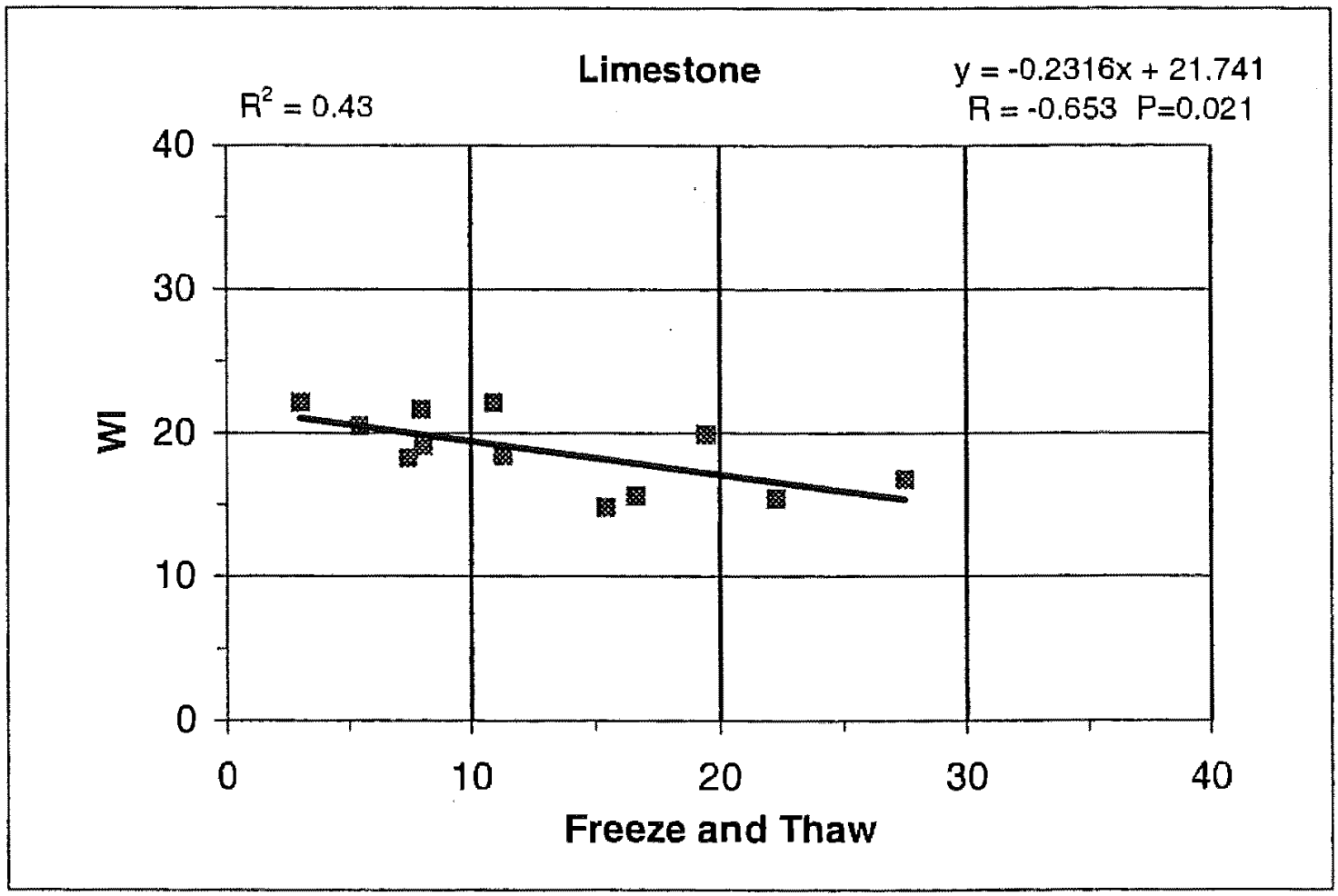

Figure 5-22. Correlation of Wear Index and Sodium sullate soundness in limestone samples 


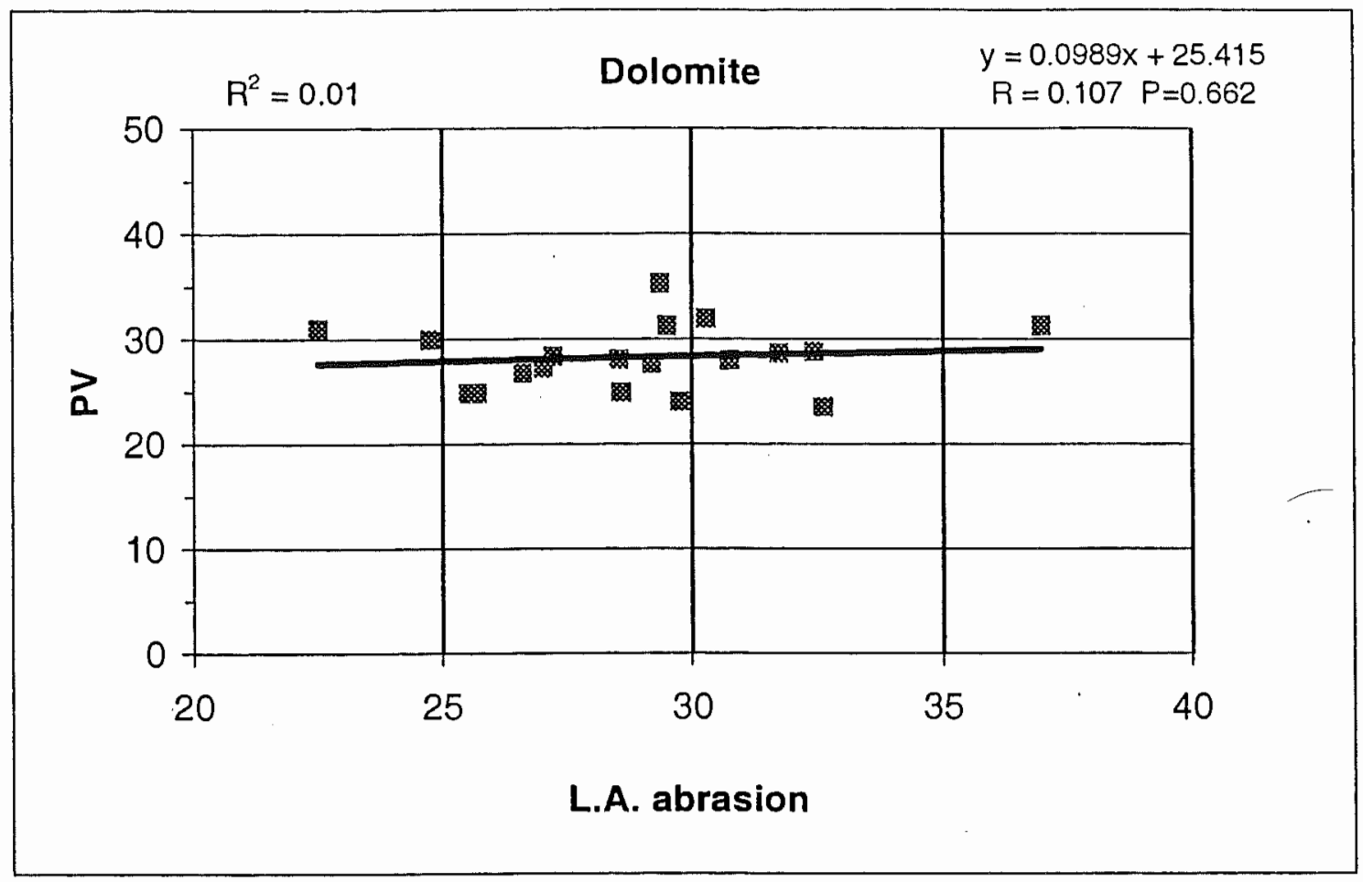

Figure 5-23. Correlation of Polished Value and L.A. Abrasion in dolomite samples

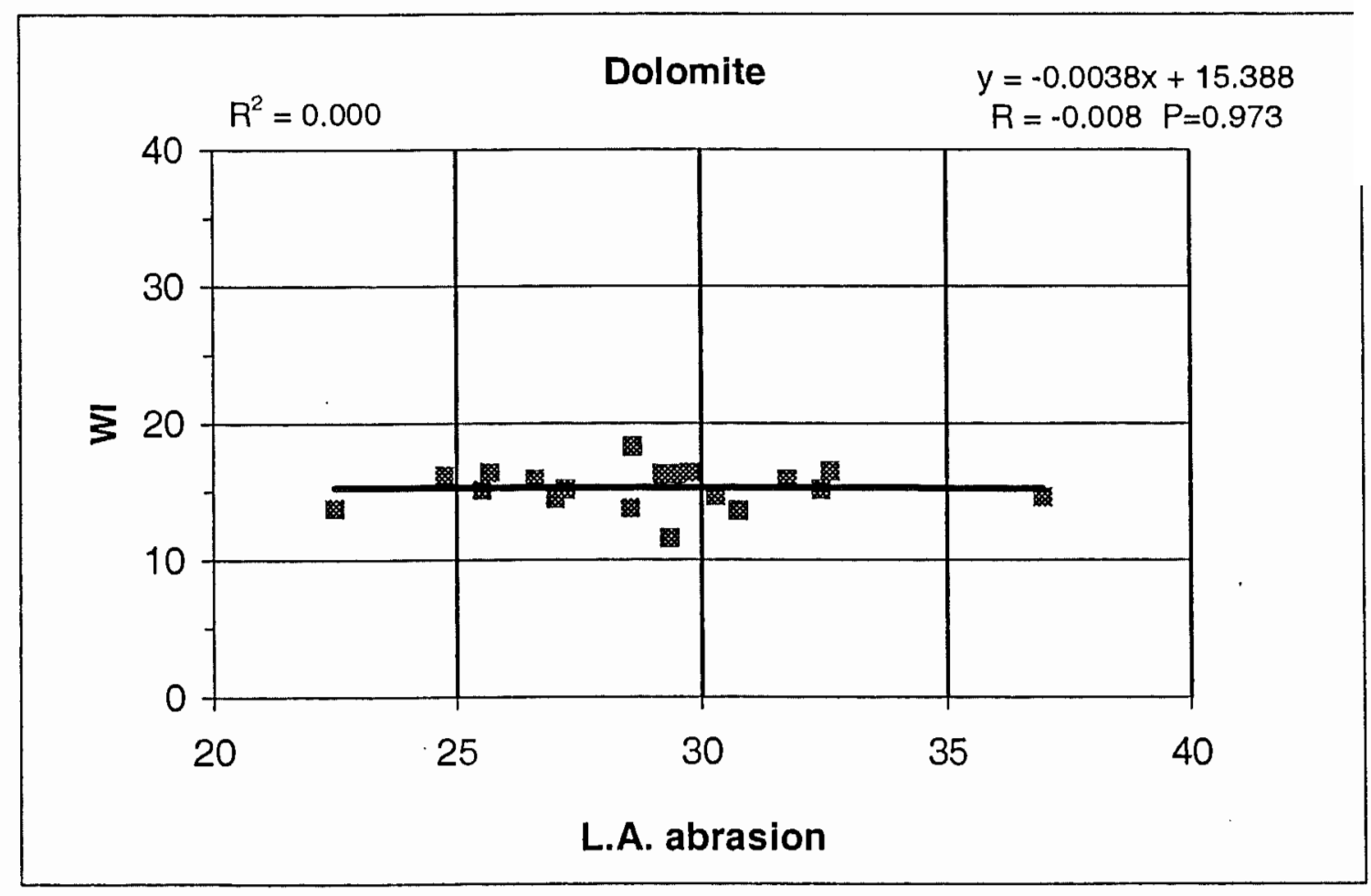

Figure 5-24. Correlation of Wear Index and L.A. Abrasion in dolomite samples 


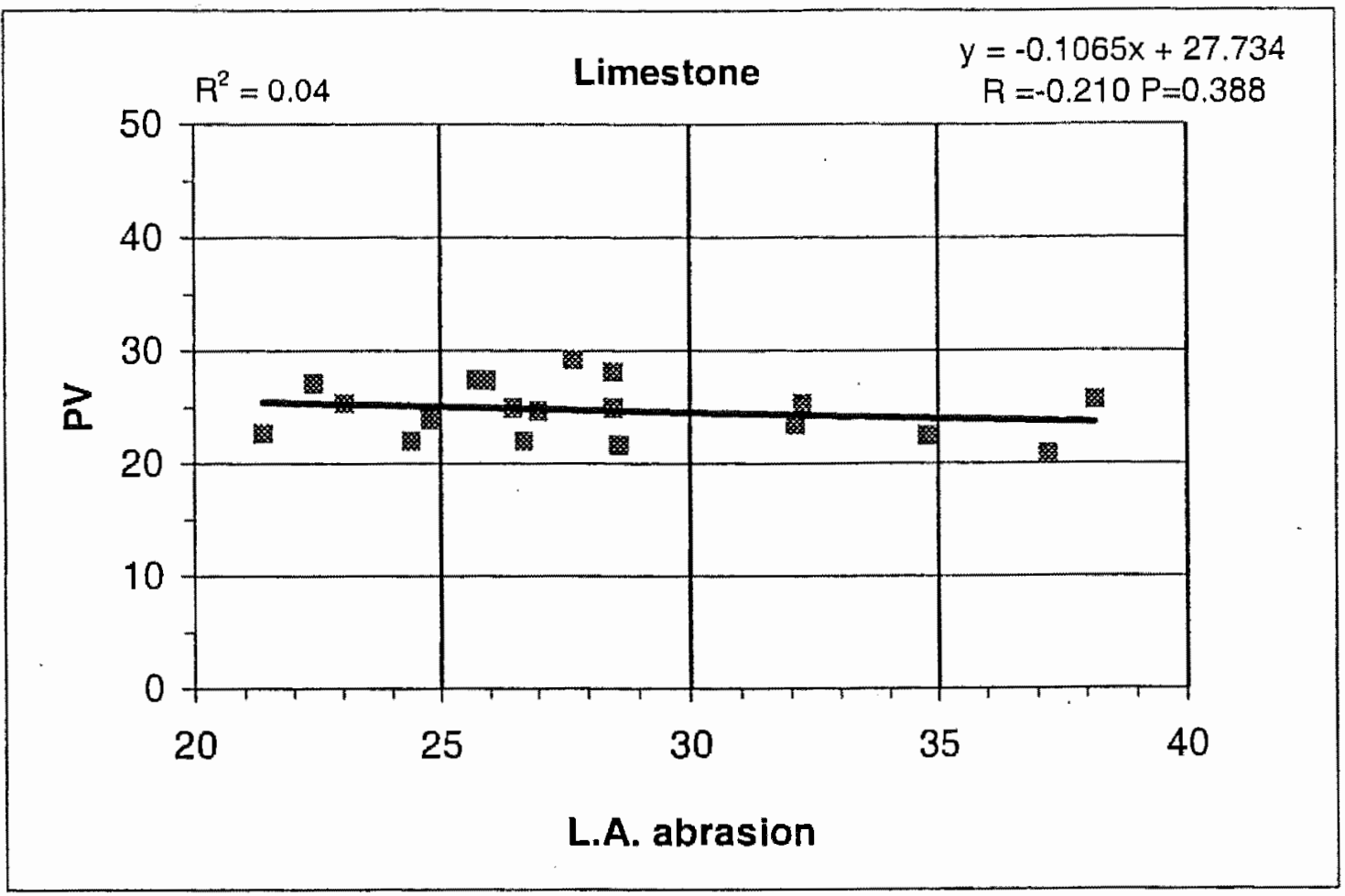

Figure 5-25. Correlation of Polished Value and L.A. Abrasion in limestone samples

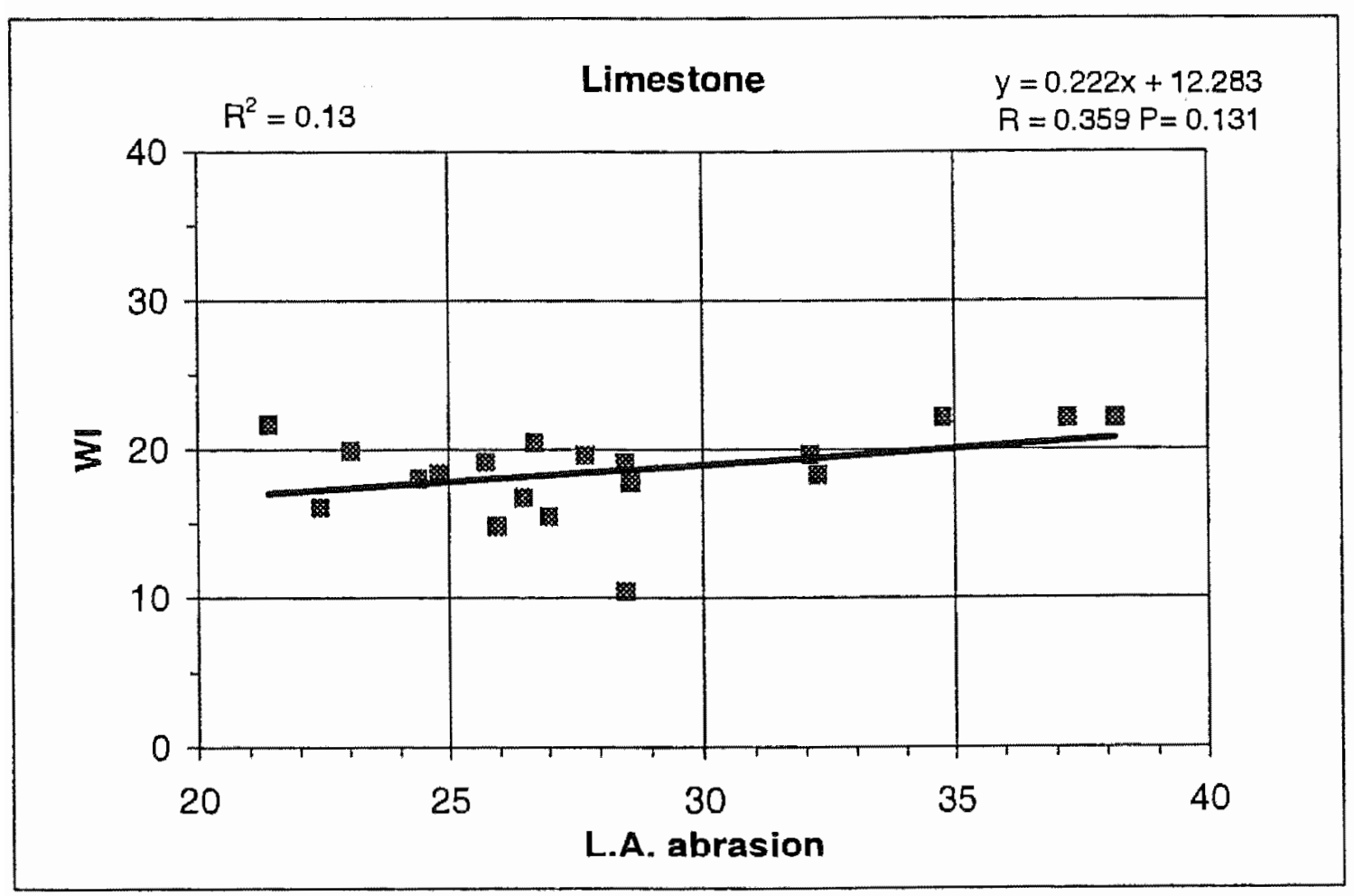

Figure 5-26. Correlation of Wear Index and L.A. Abrasion in limestone samples 


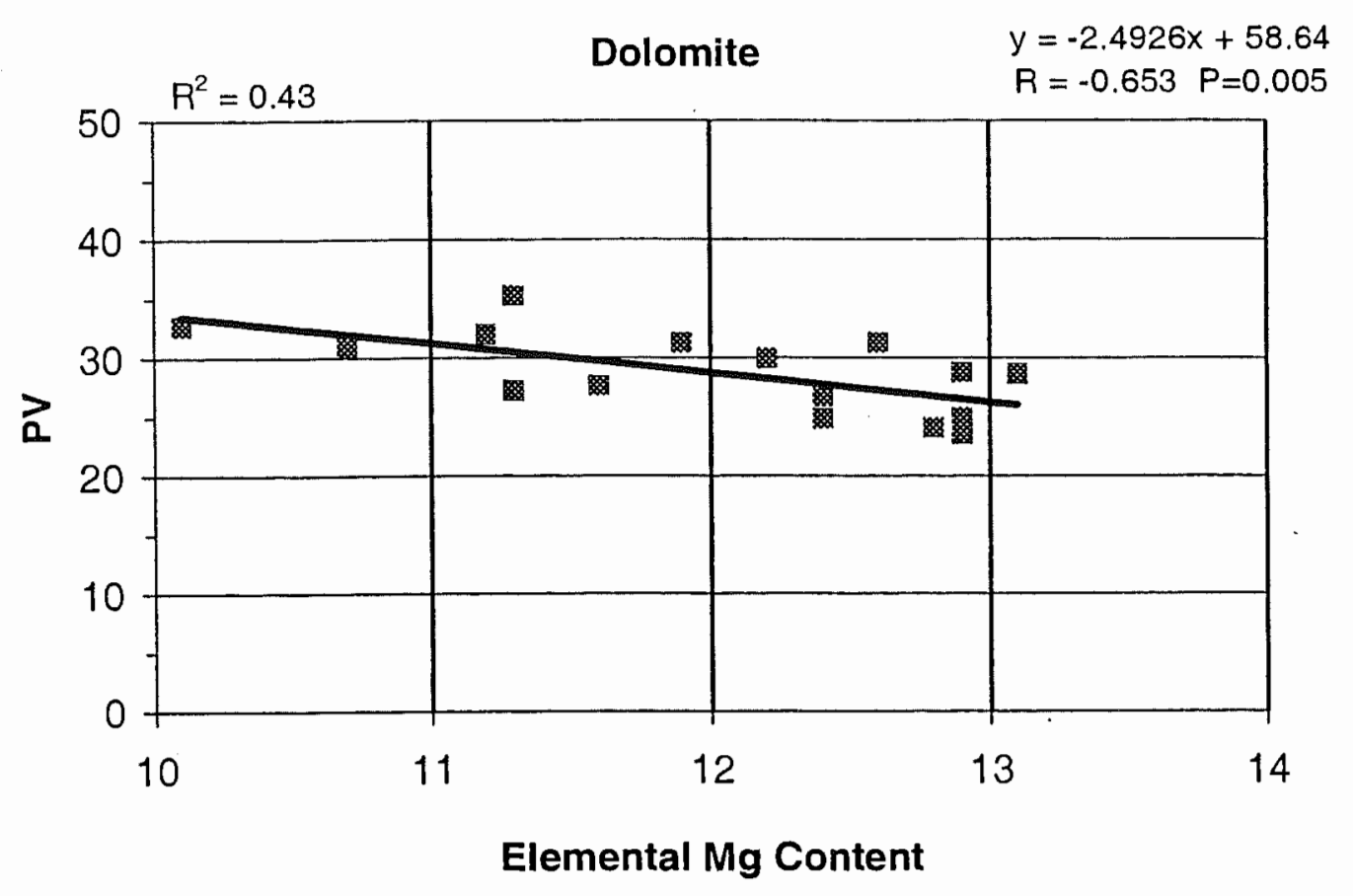

Figure 5-27. Correlation of Polished Value and Mg content in dolomite samples

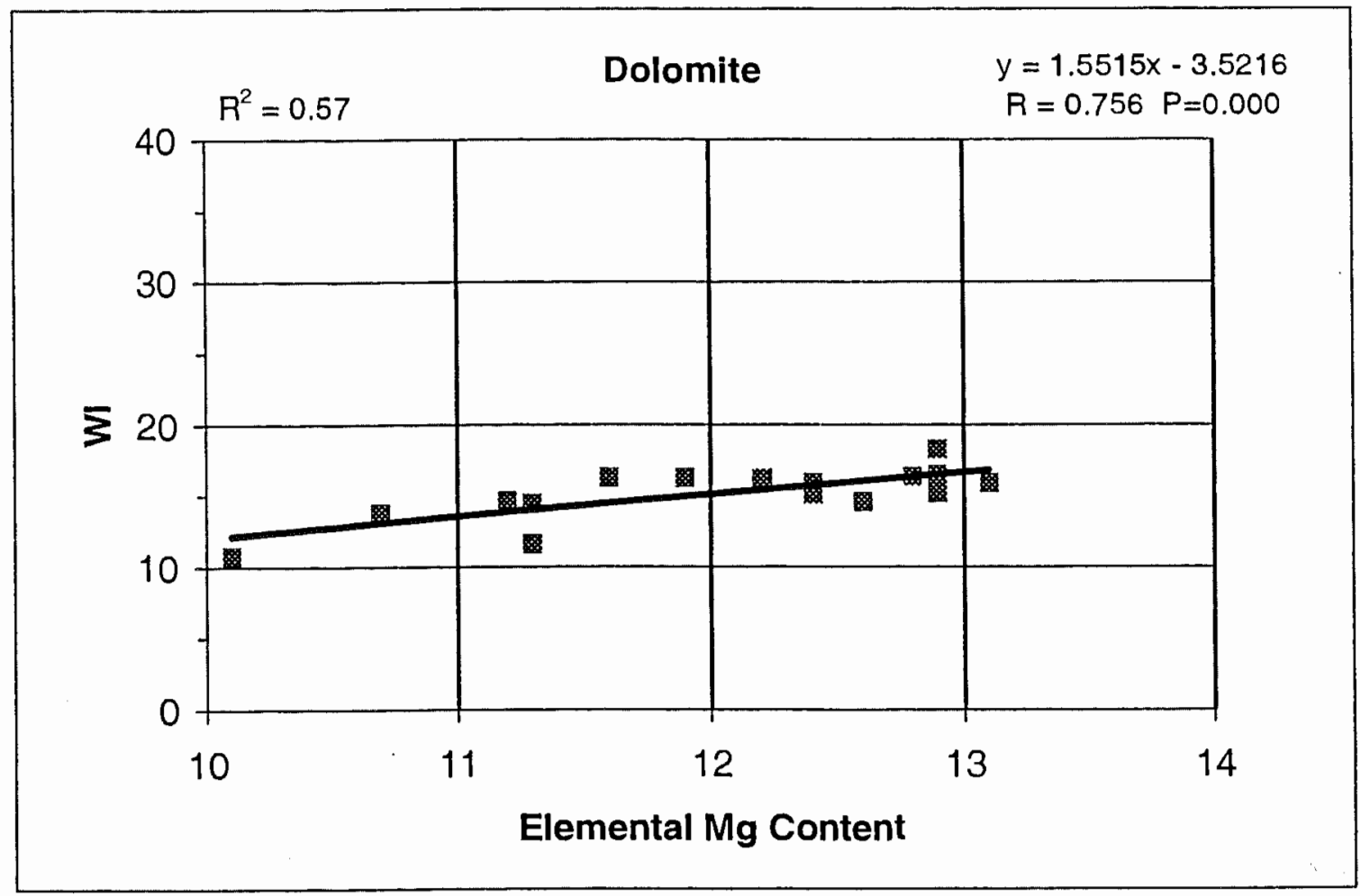

Figure 5-28. Correlation of Wear Index and Mg content in dolomite samples 


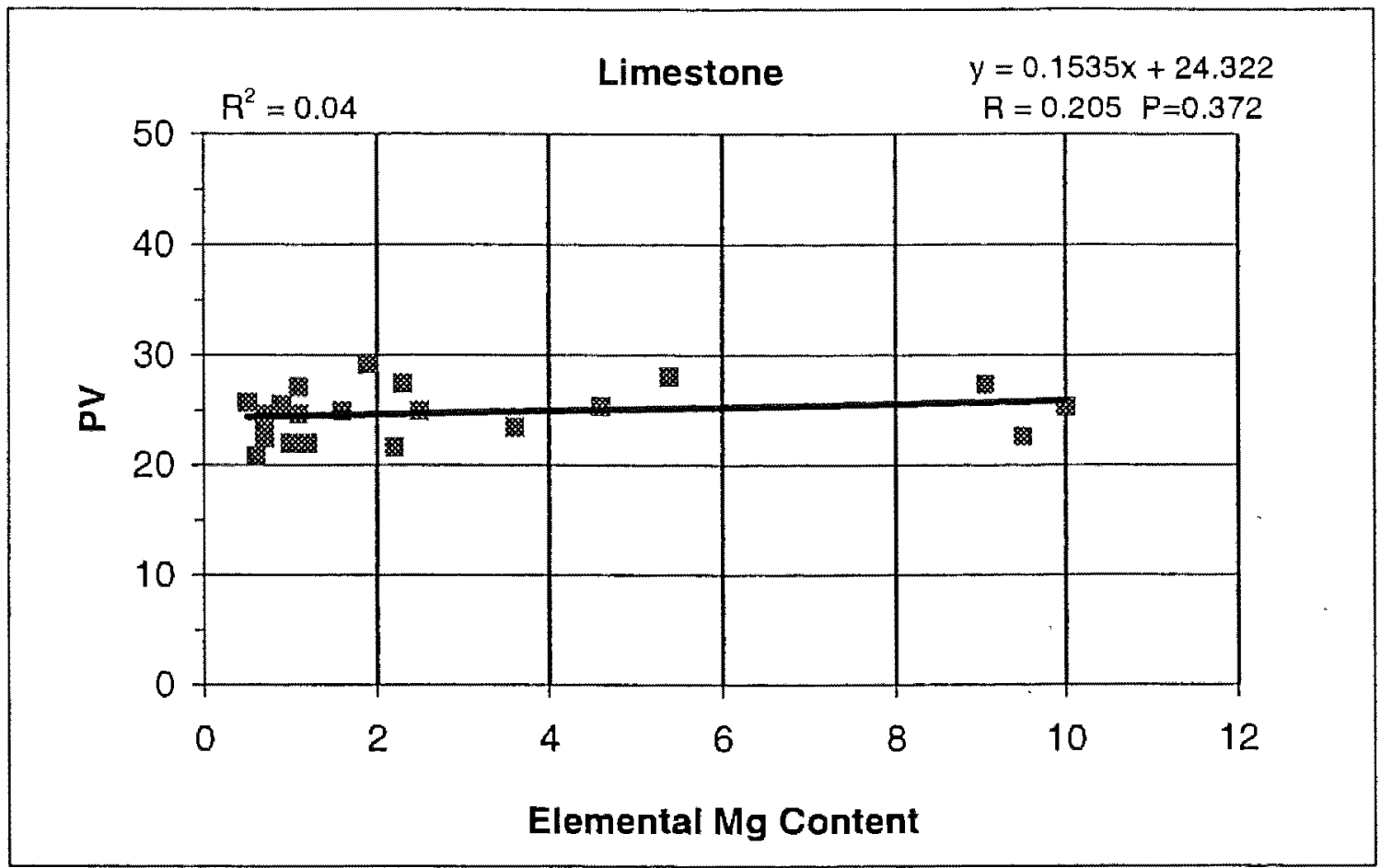

Figure 5-29. Correlation of Polished Value and Mg content in limestone samples

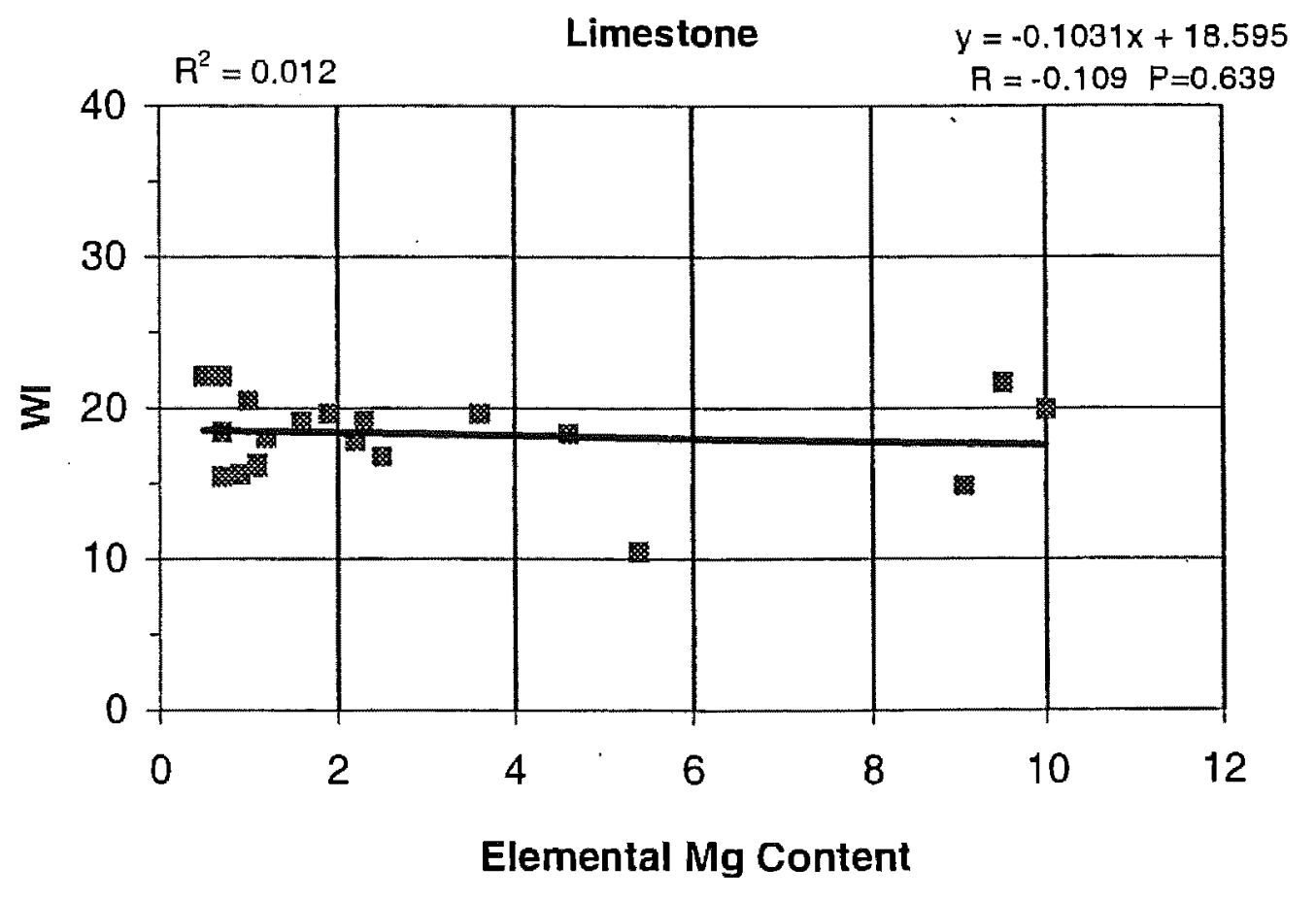

Figure 5-30. Correlation of Wear Index and Mg content in limestone samples 


\subsubsection{Acid Insoluble Residue and Frictional Properties of Carbonate Aggregates}

The data evaluated on the acid-insoluble residue test were divided into three groups. These consisted of 1) total acid-insoluble residue, 2) percent residue greater than \#200 sieve (75 microns) and 3) percent residue smaller than \#200 sieve (75 microns).

Based on the results of the comparison between PV and WI and acid-insoluble residues, both PV and WI correlate well with total acid-insoluble residue. The PV and WI are least correlated with the percent material greater than \#200. This indicates the percent amounts of smaller than $\# 200$ has a positive effect on frictional resistance.

As shown in Figures 5-31 and 5-32, total acid-insoluble residue in the dolomite samples correlate poorly with $P V\left(R=0.448, R^{2}=0.20\right.$ and $\left.P=0.048\right)$ and $W I(R=-0.255$, $\mathrm{R}^{2}=0.07$ and $\mathrm{P}=0.277$ ). However, as shown in Figures 5-33 and 5-34, total acid-insoluble residue for limestone samples correlates strongly with $P V\left(0.703, R^{2}=0.49\right.$ and $\left.P=0.000\right)$ and WI $\left(R=-0.639, R^{2}=0.41\right.$ and $\left.P=0.002\right)$. For both dolomite and limestone, as the acidinsoluble residue increases, the polished value (PV) increases and polishing susceptibility (WI) decreases.

The total acid-insoluble residue may be the most critical factor for the evaluation of limestone as a source for bituminous pavement surfaces than it is in the evaluation of dolomite because of the higher correlation of limestone PV with total acid-insoluble residue.

As shown in Figures 5-35 through 5-38, regarding percent insoluble materials greater than \#200 in dolomite samples, acid-insoluble residues do not correlate well with PV or WI. But the limestone shows a slight correlation between PV and WI and percent insoluble materials greater than $\# 200$.

As shown in Figures 5-39 through 5-42, in the case of percent insoluble materials smaller than \#200 in dolomite, the acid-insoluble residue shows a moderate correlation with $P V\left(R=0.560, R^{2}=0.26\right.$ and $\left.P=0.010\right)$ and $W I\left(R=-0.286, R^{2}=0.08\right.$ and $\left.P=0.222\right)$. The acid-insoluble residue of limestones is well correlated with $P V\left(R=0.616, R^{2}=0.38\right.$ and $\mathrm{P}=0.003)$ and $\mathrm{WI}\left(\mathrm{R}=-0.623, \mathrm{R}^{2}=0.39\right.$ and $\left.\mathrm{P}=0.003\right)$. 
As shown in Figures 5-43 through 5-46, the ratio of percent insoluble residue greater than \#200 to percent insoluble residue smaller than \#200 does not correlate well with PV or WI.

From the above results for both dolomite and limestone, it is important to note that as the acid-insoluble residues increase, the polished values increase and polishing susceptibility decreases. Particularly for the total acid-insoluble residue, there is a strong correlation for limestone aggregates.

\subsubsection{Field and Laboratory Testing}

The frictional resistance of aggregates can be evaluated using field tests. In this. method the level of friction is measured on traveled sections of selected highways using the towed friction trailer (ASTM Standard E274). Recorded friction values for a given road surface are known as Average Friction Numbers (AFN). Typically both the Average Friction Numbers from the smooth and from ribbed tires are reported (Friction Number Smooth (FNS) and Friction Number Ribbed (FNR)).

An AFN of 20 for the FNS and of 30 for FNR are values of concern used by INDOT to indicate the need for follow-up evaluations to determine if corrective action or the pavement may be required.

After the field test was performed with towed trailers on the highway, 8-in cores were obtained and brought to INDOT lab. Then the aggregate was extracted from the cores. Fresh pieces of $+9.5 \mathrm{~mm}$ size were used to construct coupons. Coupons were measured using the British Pendulum before and after polishing by the British Wheel test

Following extraction of aggregates from core samples, coupons were prepared and tested in the same way as that used for quarried aggregates. This allowed for a direct comparison between laboratory friction values and those obtained in the field.

Correlation analysis between BPN and AFN was performed on the carbonate aggregates. As shown in Figures 5-47 and 5-48, the FNR and FNS are more highly correlated with IFV than with PV. Using these correlations, the FNR=30 corresponds to $P V=24.7$ and $I F V=36.9$. The FNS=20 corresponds to $P V=19.2$ and $I F V=30.5$. In all, $a$ PV of 25 may be considered as a minimum, acceptable friction value. The $P V=25$ 
corresponds to $\mathrm{FNS}=27.7$ and $\mathrm{FNR}=30.7$. However, these correlations were performed using only 6 data points, but showed a high significance level $(P=0.067-0.106)$ for $P V$. 


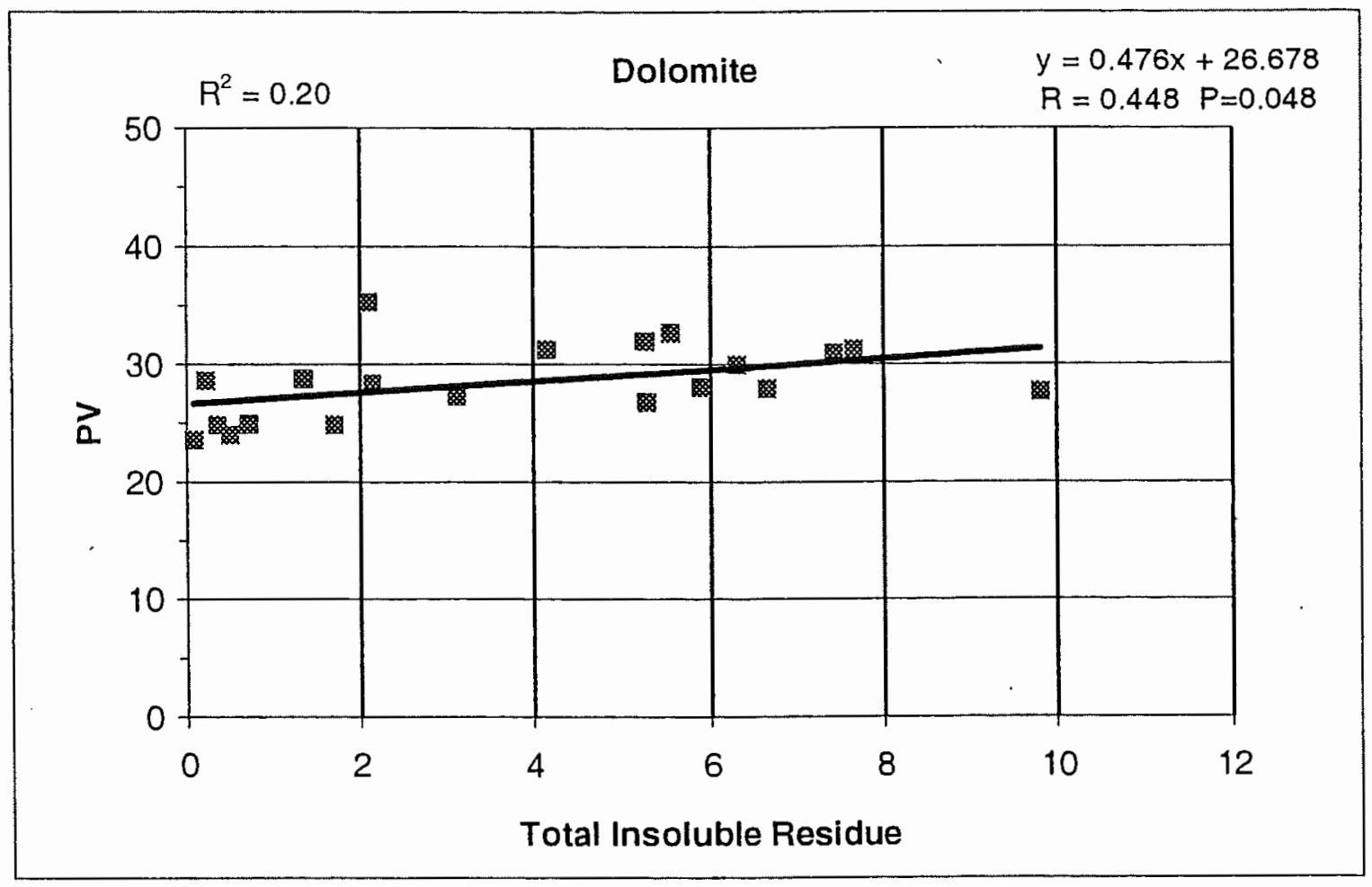

Figure 5-31. Correlation of Polished Value and Total insoluble residue in dolomite samples

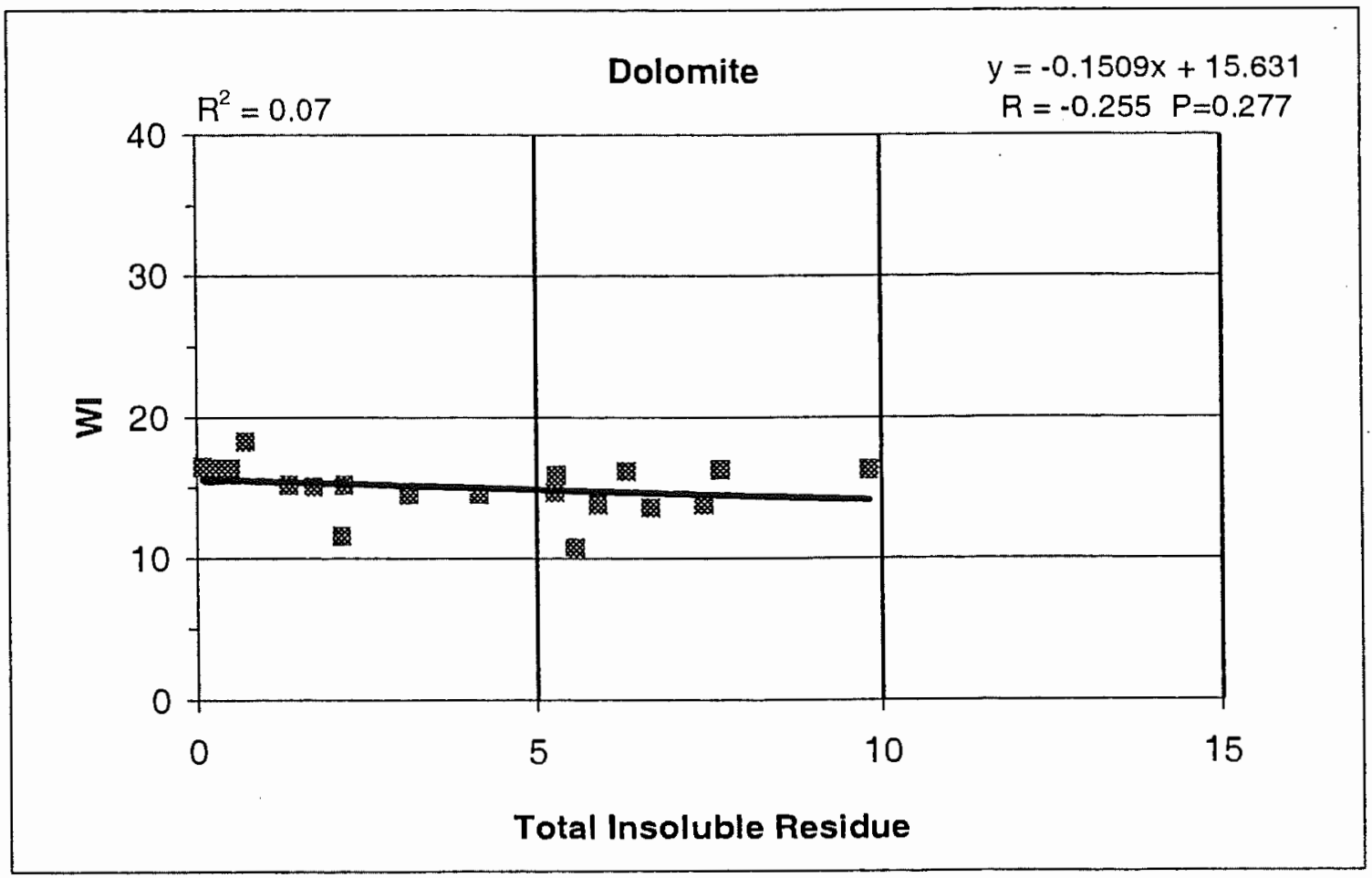

Figure 5-32. Correlation ofWear Index and Total insoluble residue in dolomite samples 


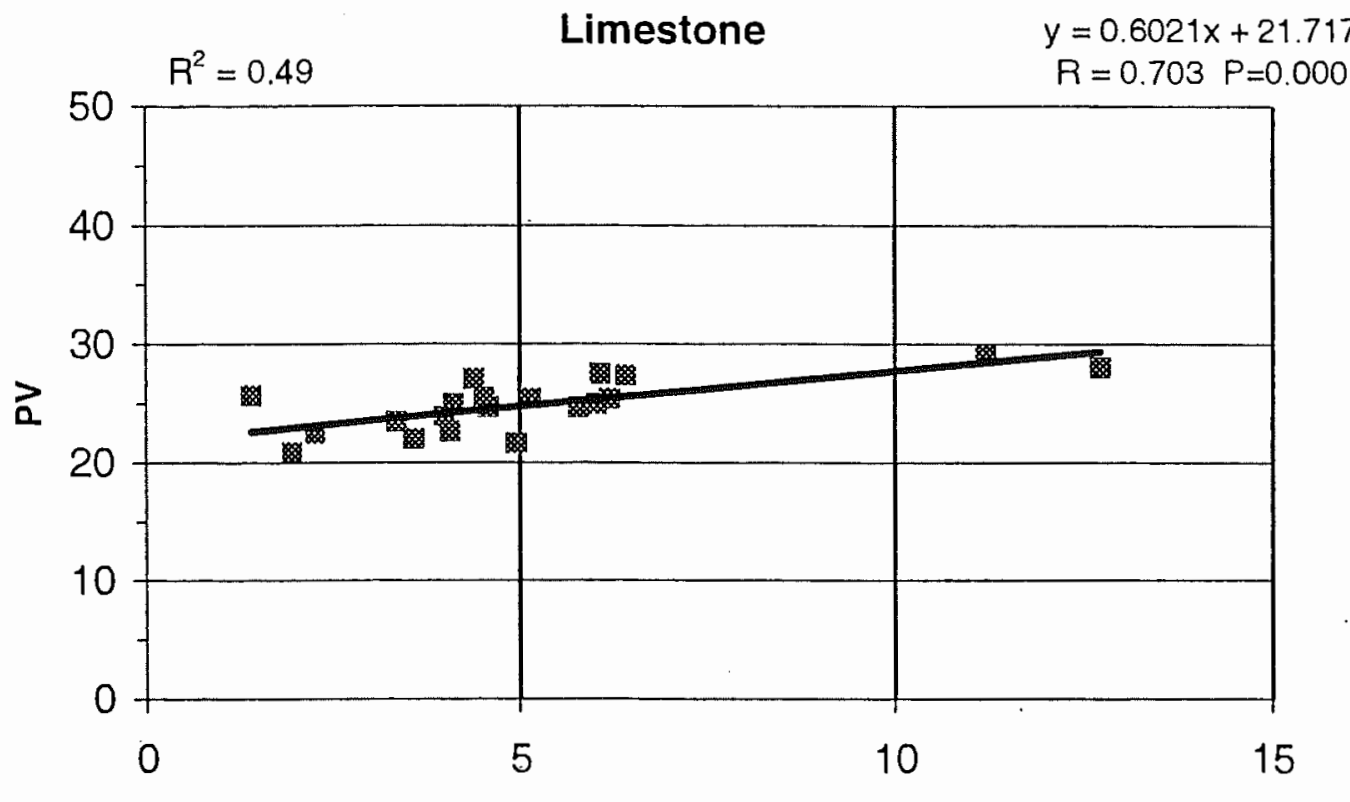

Total Insoluble Residue

Figure 5-33. Correlation of Polished Value and Total insoluble residue in limestone samples

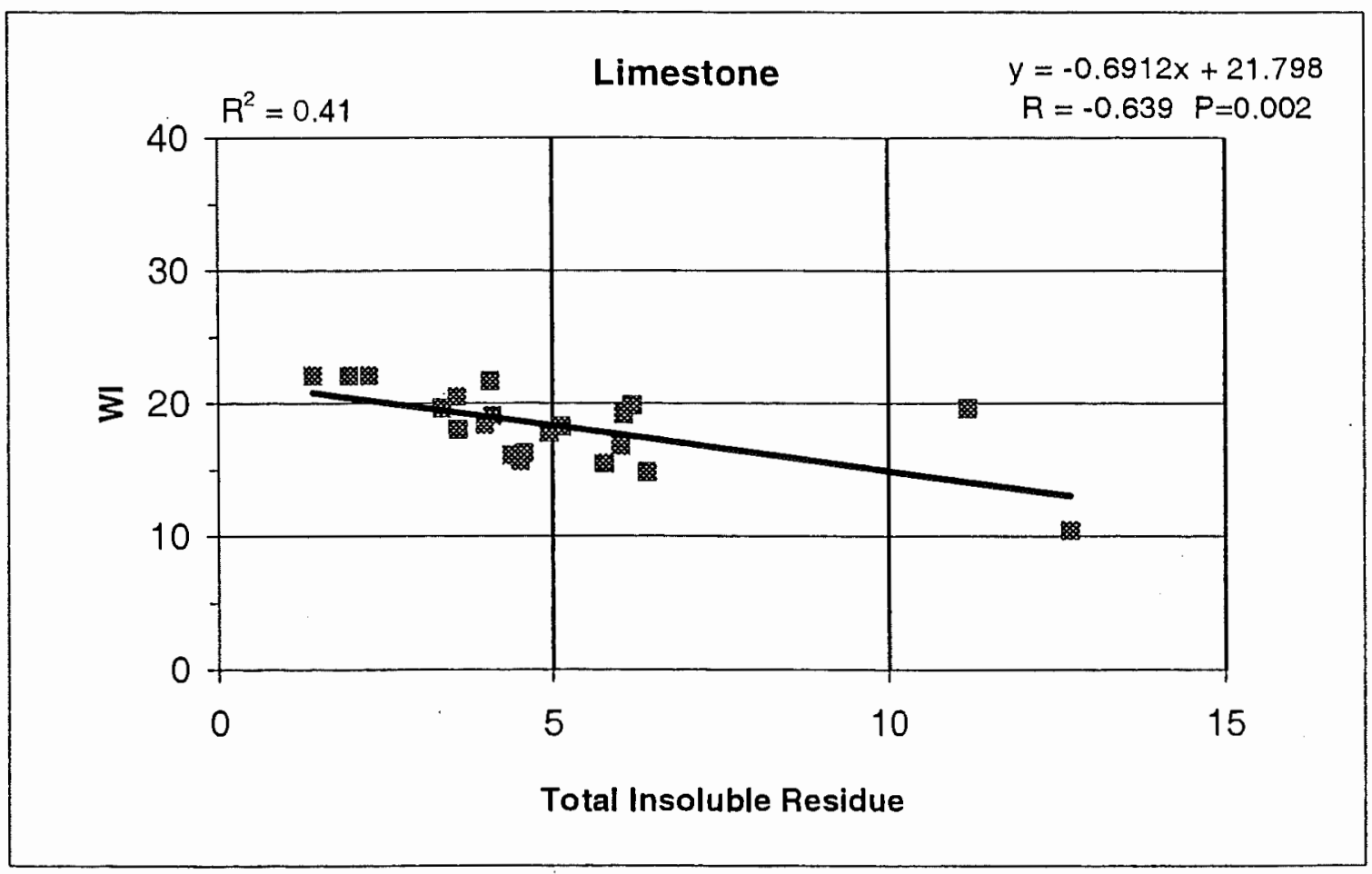

Figure 5-34. Correlation ofWear Index and Total insoluble residue in limestone samples 


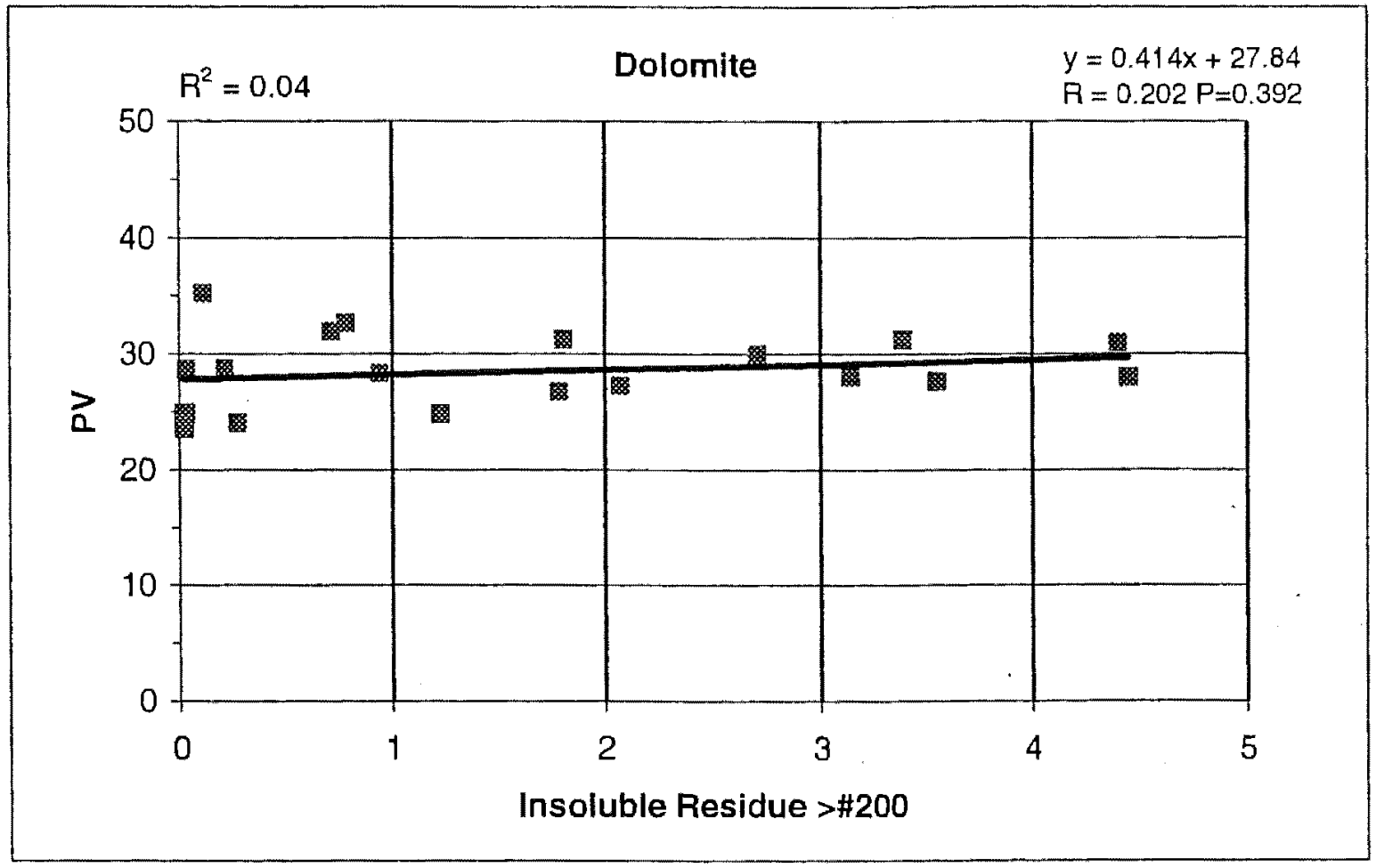

Figure 5-35. Correlation of Polished Value and insoluble residue $>\# 200$ in dolomite samples

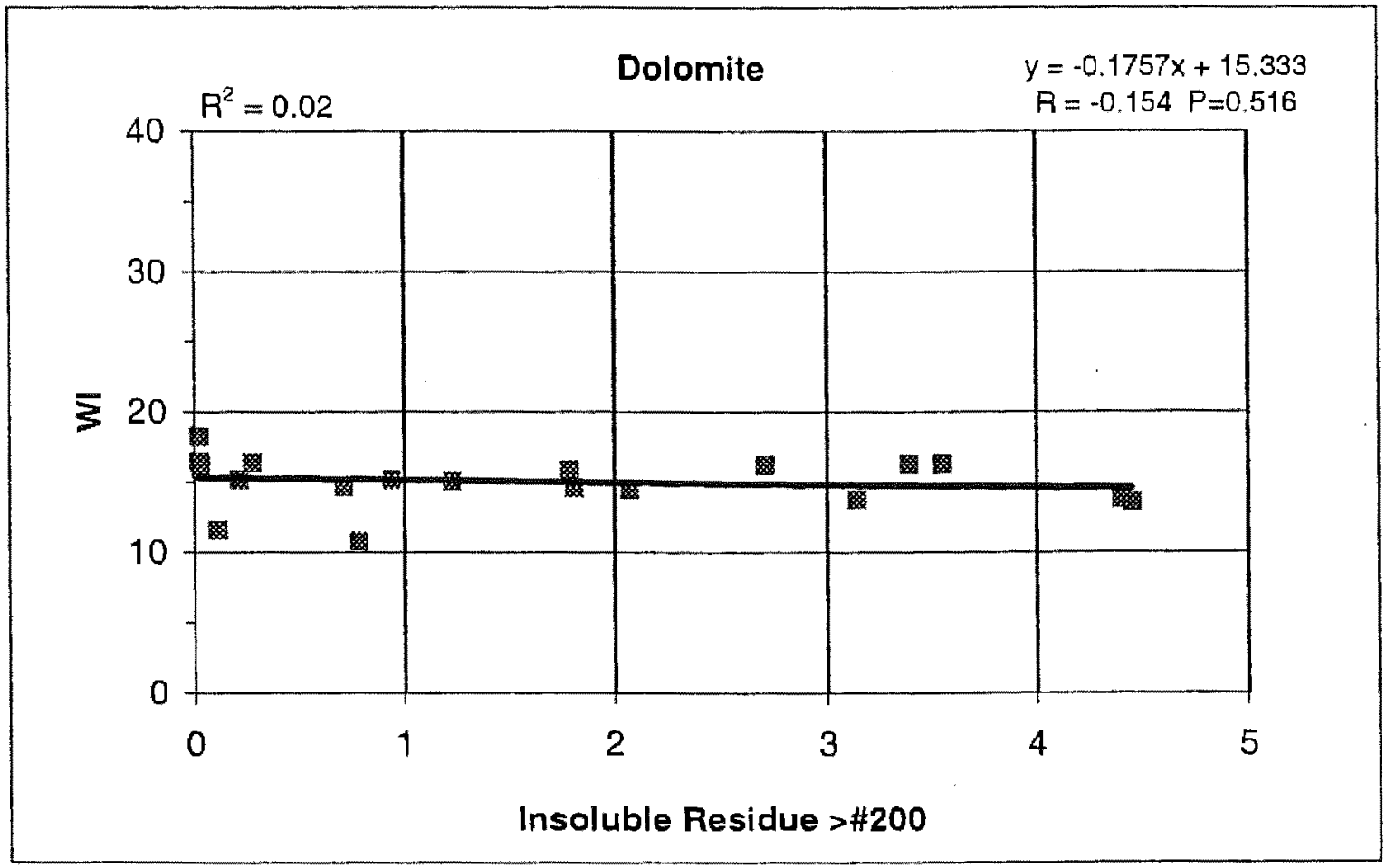

Figure 5-36. Correlation ofWear Index and insoluble residue $>\# 200$ in dolomite samples 

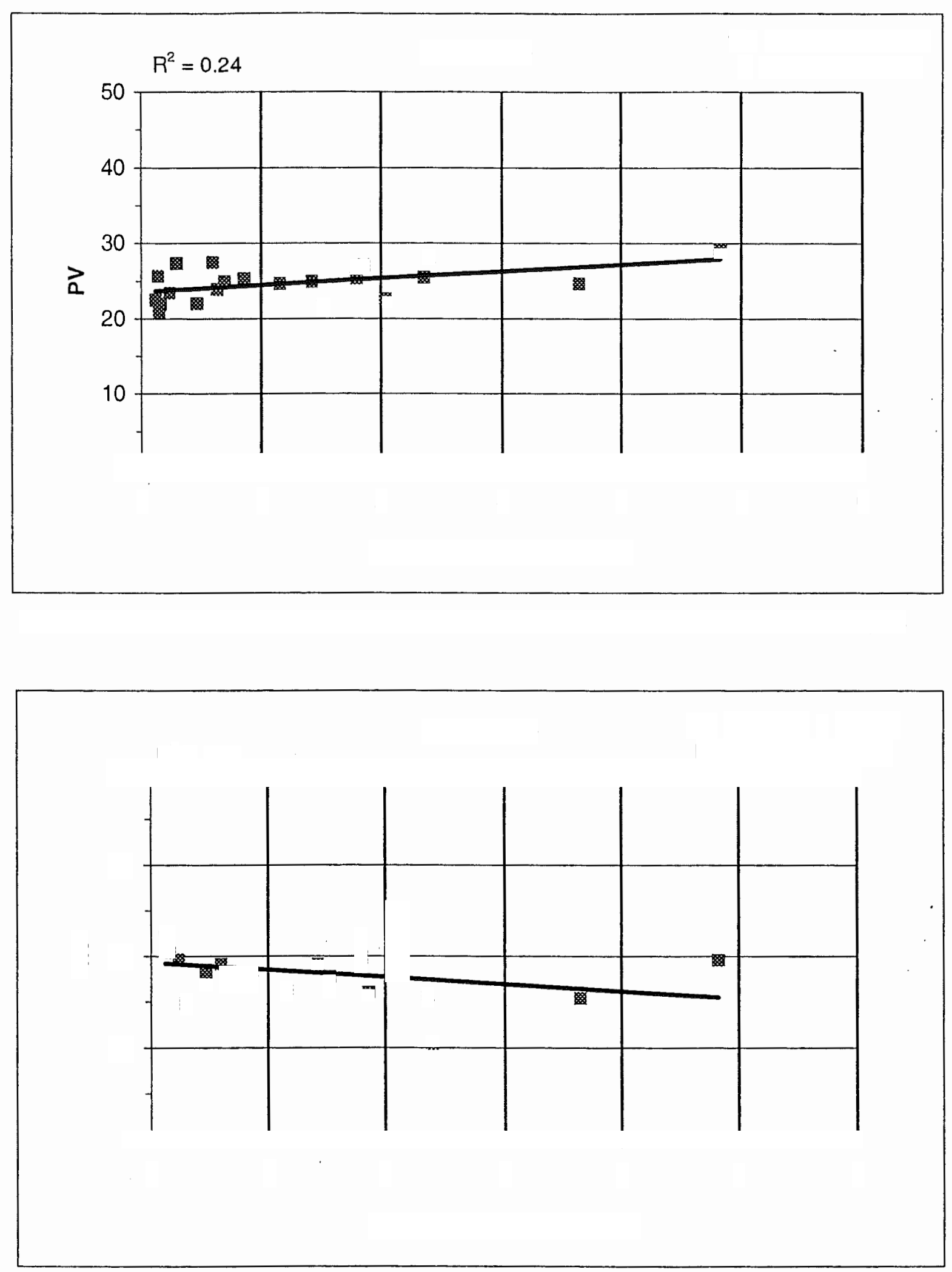


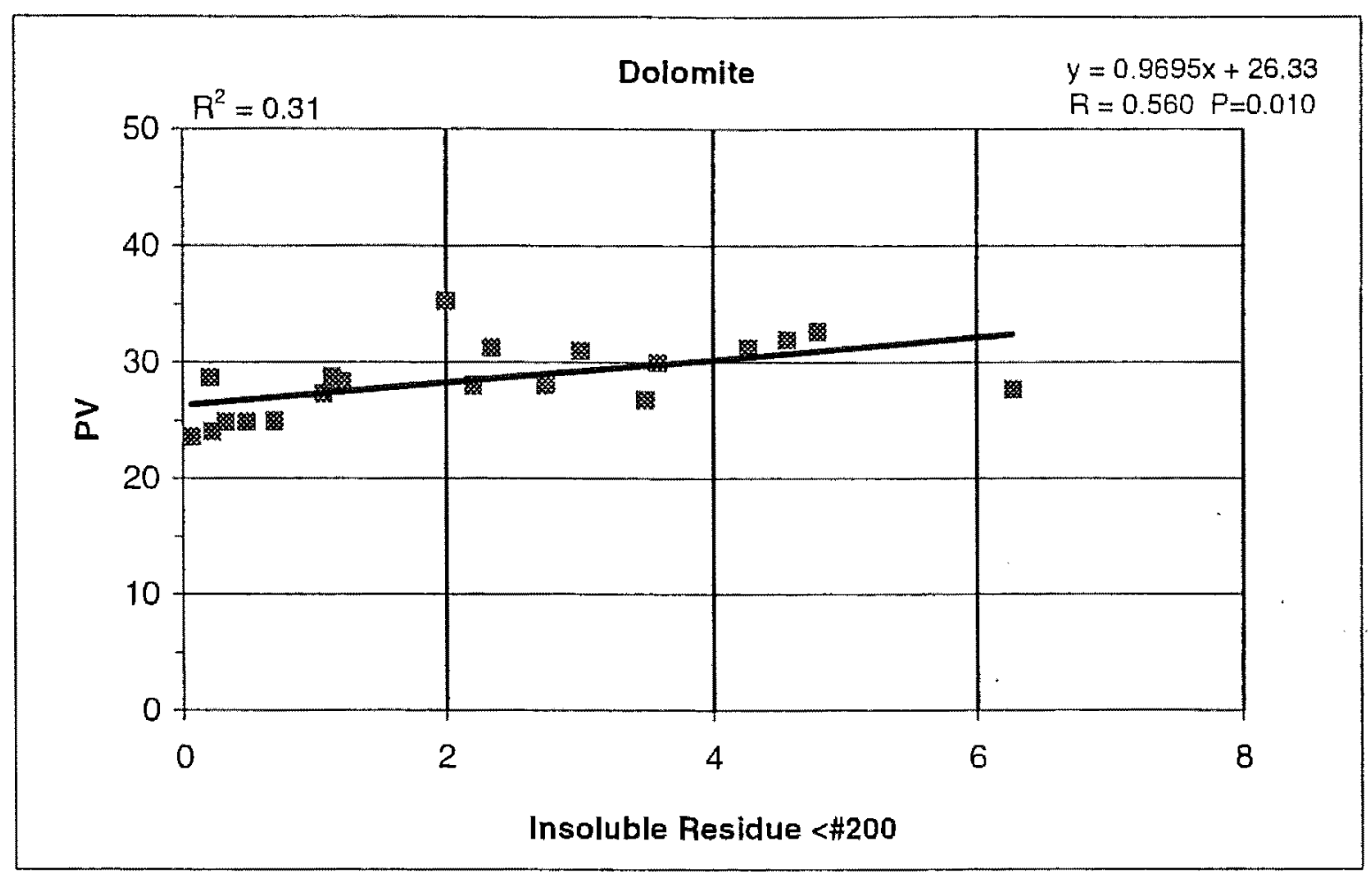

Figure 5-39. Correlation of Polished Value and insoluble residue $<\$ 200$ in dolomite samples

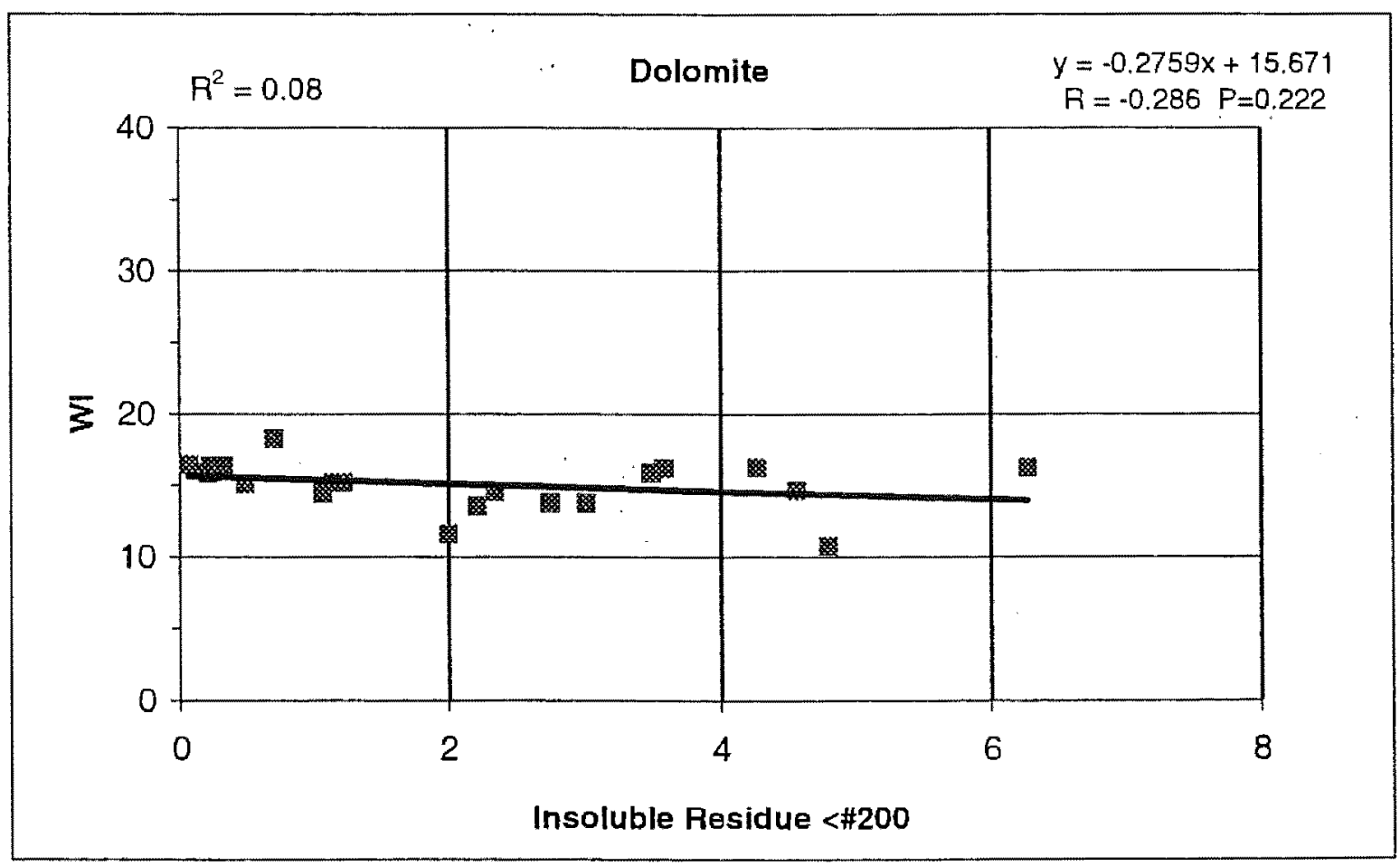

Figure 5-40. Correlation ofWear Index and Total insoluble residue in dolomite samples 


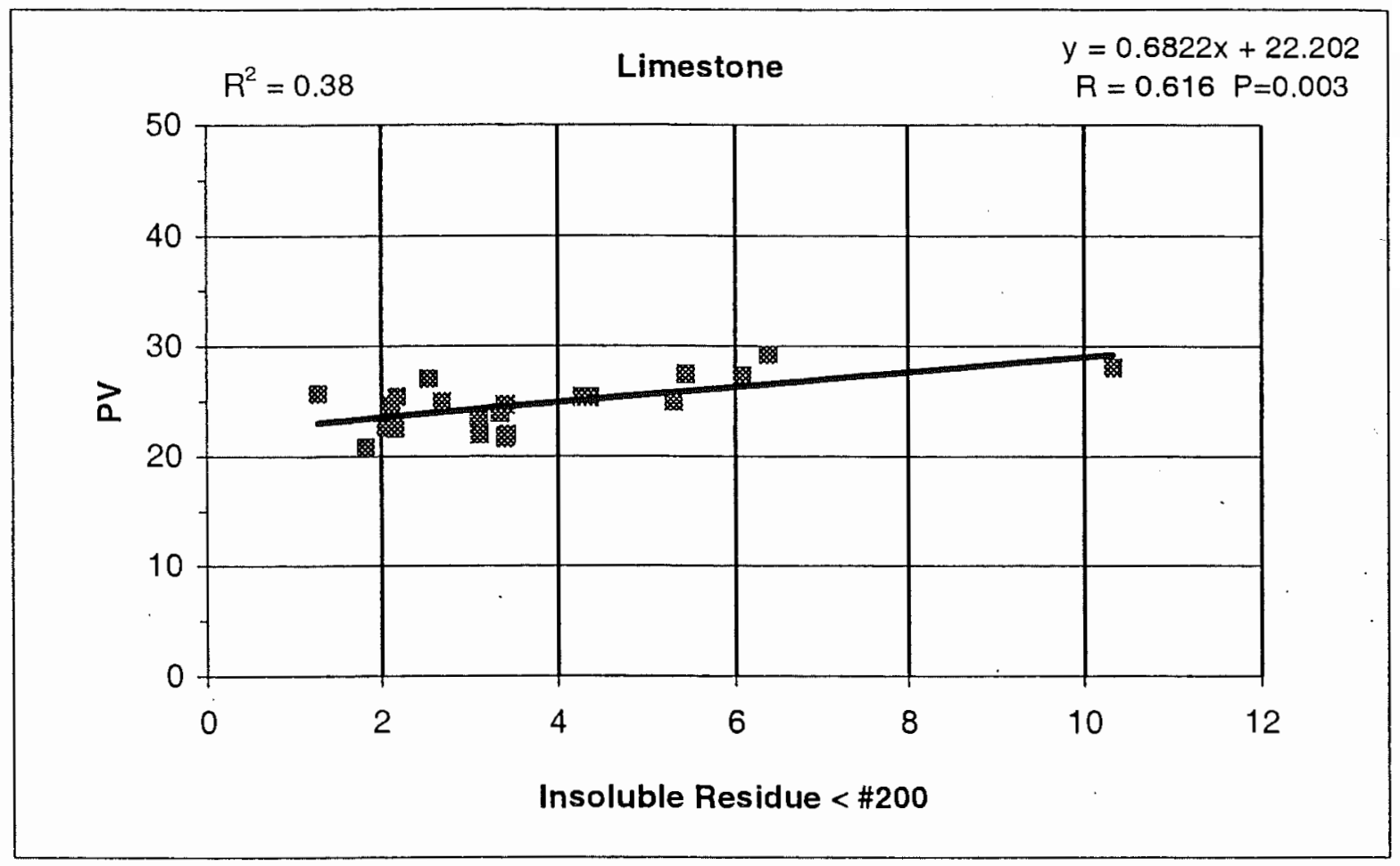

Figure 5-41. Correlation of Polished Value and insoluble residue $\ll 200$ in limestone samples

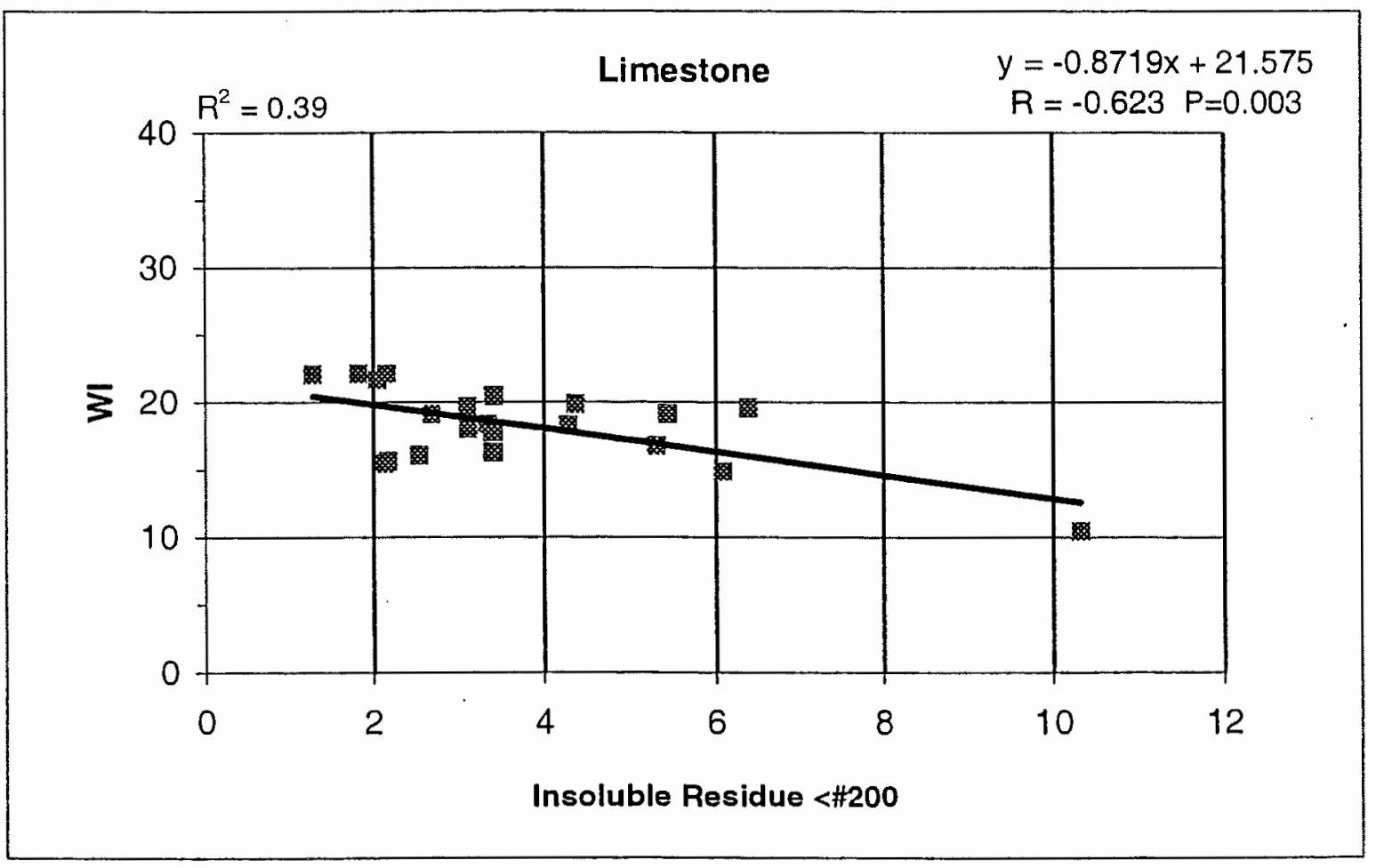

Figure 5-42. Correlation of Wear Index and insoluble residue <\#200 in limestone samples 


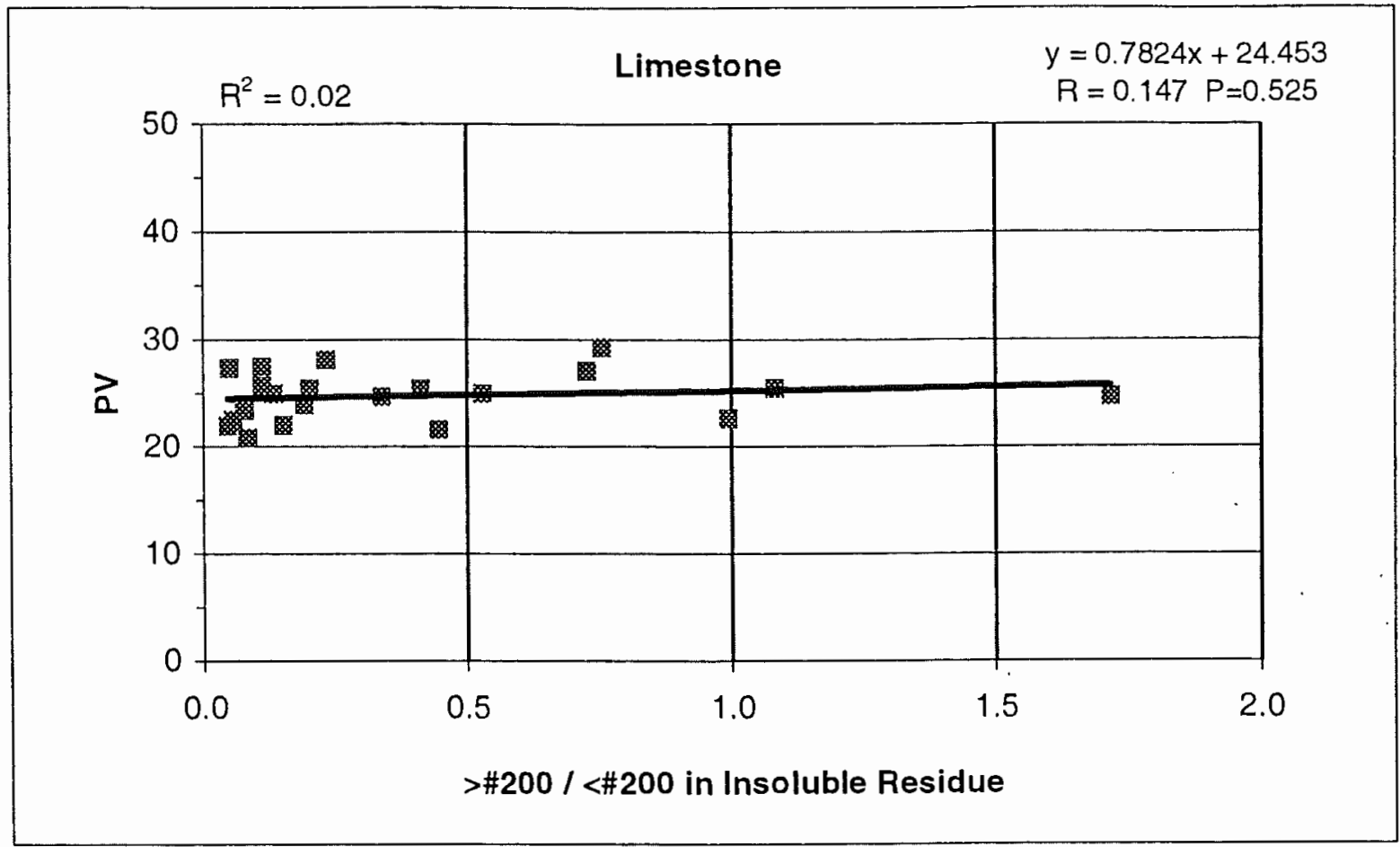

Figure 5-43. Correlation of Polished Value and the ratio of $>\# 200 /<\# 200$ in insoluble residue in limestone samples

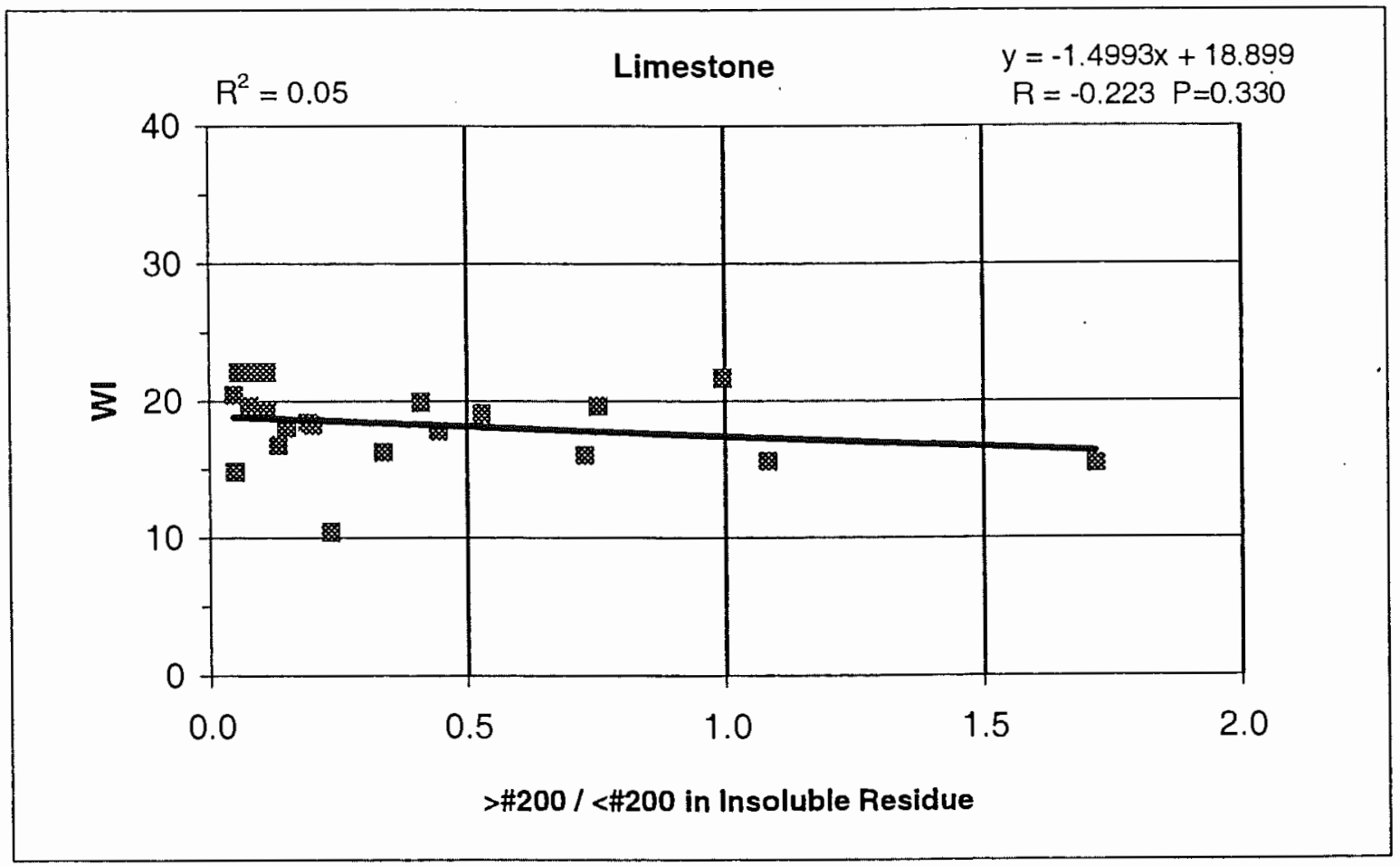

Figure 5-44. Correlation of Wear Index and the ratio of $>\# 200 /<\# 200$ in insoluble residue in limestone samples 


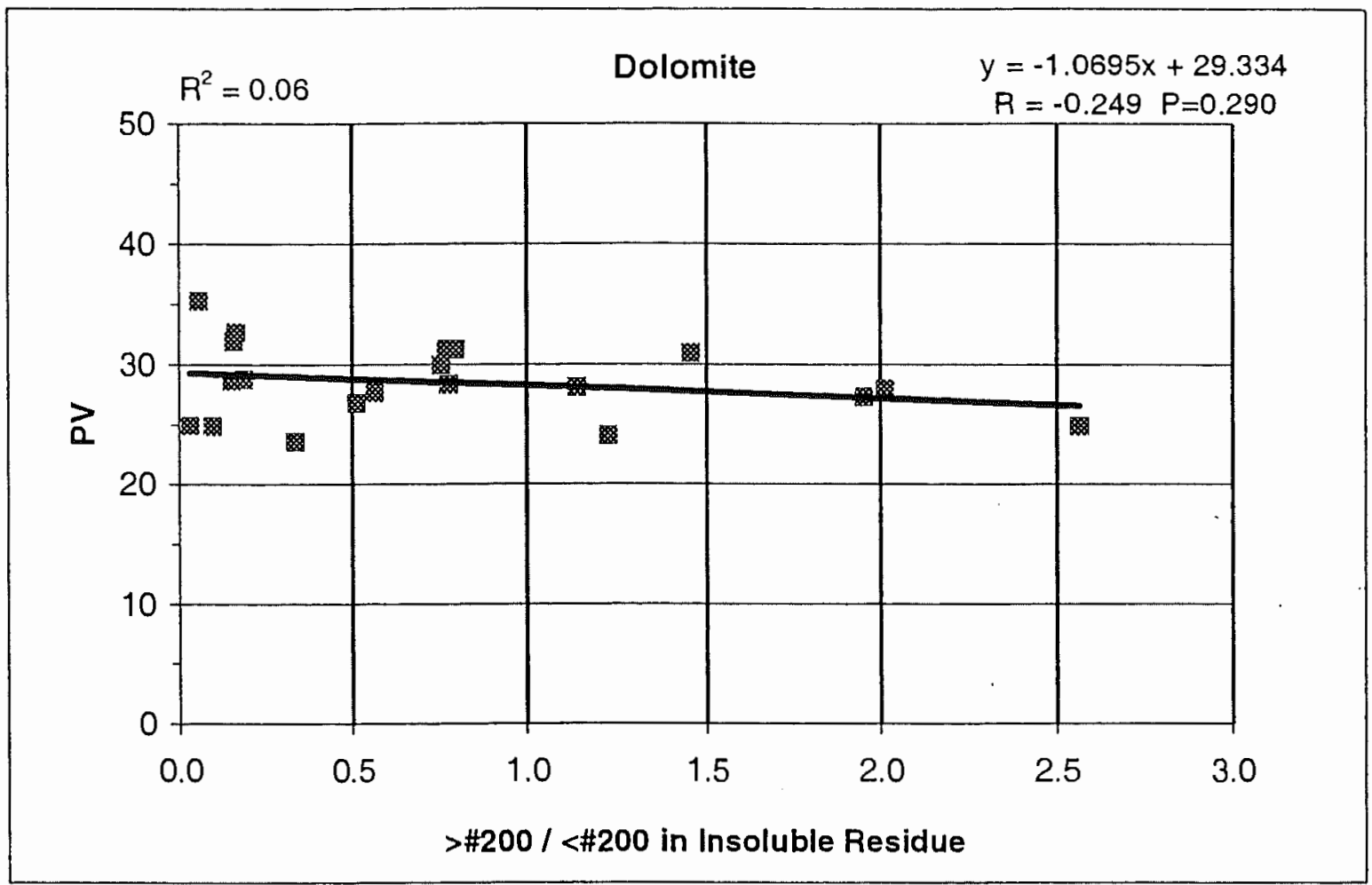

Figure 5-45. Correlation of Polished Value and the ratio of $>\# 200 /<\# 200$ in insoluble residue in dolomite samples

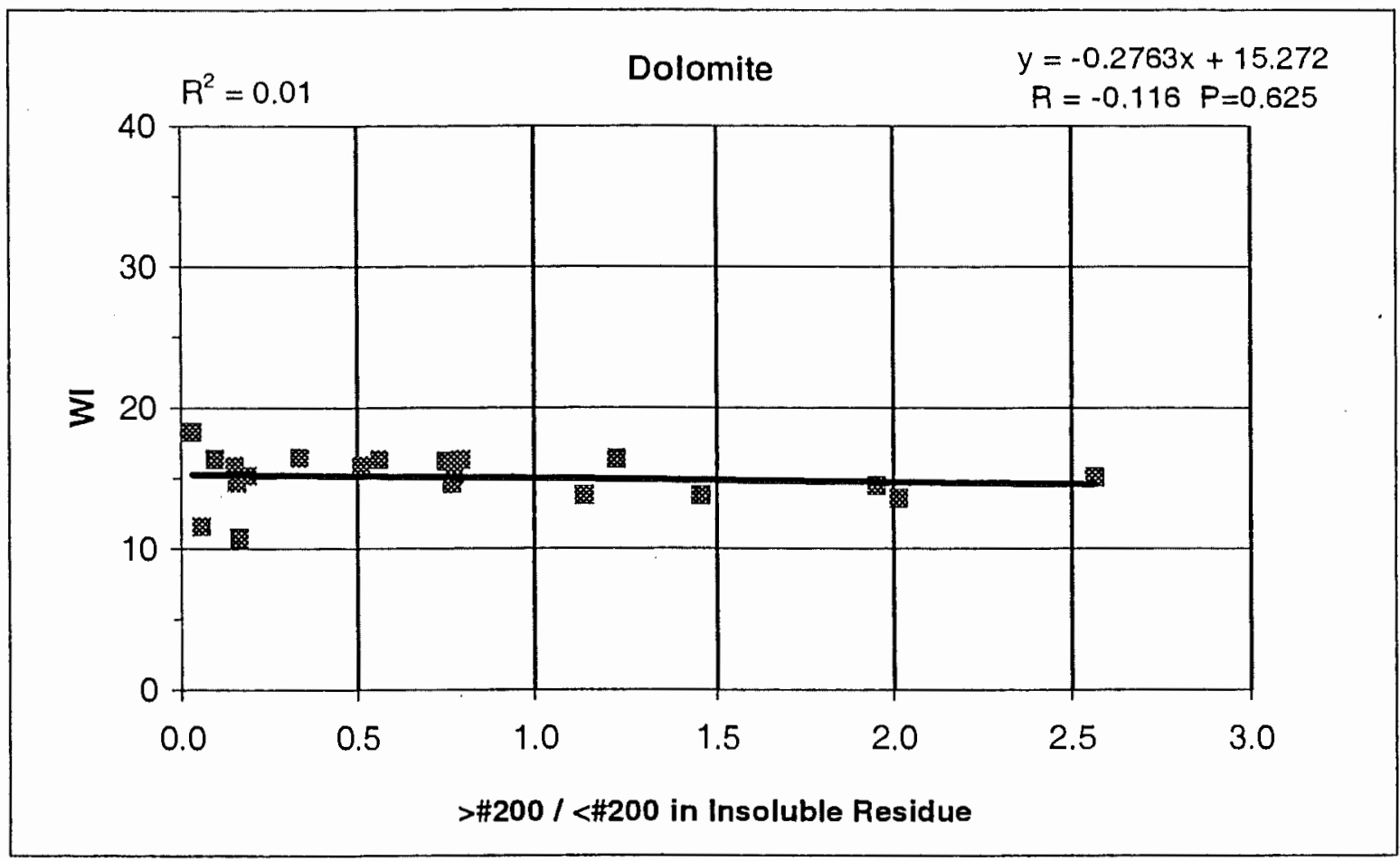

Figure 5-46. Correlation of Wear Index and the ratio of $>\# 200 /<\# 200$ in insoluble residue in dolomite samples 
Table 5-9. Correlation matrix for carbonate aggregates

A. Limestone

\begin{tabular}{|c|c|c|c|c|c|c|c|c|c|c|c|c|}
\hline & IFV & PV & $|W|$ & $A B$ & SPG & LA & $\mathrm{F}-\mathrm{T}$ & $M G$ & T_ACID & P_200 & M_200 & RATIO \\
\hline \multirow[t]{3}{*}{ IFV } & 1 & 0.32288 & 0.6628 & 0.10318 & -0.20263 & 0.20225 & -0.58439 & 0.05871 & -0.08972 & 0.05221 & -0.14758 & -0.11676 \\
\hline & ol & 0.1534 & 0.0011 & 0.6651 & 0.3916 & 0.4063 & 0.046 & 0.8004 & 0.699 & 0.8222 & 0.5232 & 0.6142 \\
\hline & 21 & 21 & 21 & 20 & 20 & 19 & 12 & 21 & 21 & 21 & 21 & 21 \\
\hline \multirow[t]{3}{*}{ PV } & 0.32288 & 1 & -0.49469 & 0.0474 & $-0,0725$ & -0.21025 & 0.28632 & 0.20545 & 0.70343 & 0.48816 & 0.61593 & 0.1469 \\
\hline & .1534 & 0 & 0.0226 & 0.8427 & 0.7613 & 0.3876 & 0.3669 & 0.3716 & 0.0004 & 0.0248 & 0.003 & 0.5252 \\
\hline & 21 & 21 & 21 & 20 & 20 & 19 & 12 & 21 & 21 & 21 & 21 & 21 \\
\hline \multirow[t]{3}{*}{ WI } & 0.6628 & -0.49469 & 1 & 0.05648 & -0.1274 & 0.35913 & -0.6528 & -0.10864 & -0.63892 & -0.33827 & -0.62283 & -0.22344 \\
\hline & 0.0011 & 0.0226 & 0 & 0.813 & 0.5925 & 0.131 & 0.0214 & 0.6392 & 0.0018 & 0.1336 & 0.0026 & 0.3302 \\
\hline & 21 & 21 & 21 & 20 & 20 & 19 & 12 & 21 & 21 & 21 & 21 & 21 \\
\hline \multirow[t]{3}{*}{$\overline{A B}$} & 0.10318 & 0.0474 & 0.05648 & $\overline{1}$ & -0.75713 & 0.10063 & -0.13827 & 0.40689 & 0.00952 & -0.05069 & 0.04289 & 0.00236 \\
\hline & 6651 & 0.8427 & 0.813 & 0 & 0.0001 & 0.6819 & 0.6683 & 0.075 & 0.9682 & 0.8319 & 0.8575 & 0.9921 \\
\hline & 20 & 20 & 20 & 20 & 20 & 19 & 12 & 20 & 20 & 20 & 20 & 20 \\
\hline \multirow[t]{3}{*}{$S P G$} & -0.20263 & -0.0725 & -0.1274 & -0.75713 & 1 & -0.36788 & 0.19899 & 0.05525 & 0.11193 & -0.11354 & 0.21331 & -0.22235 \\
\hline & 0.3916 & 0.7613 & 0.5925 & 0.0001 & 0 & 0.1212 & 0.5353 & 0.817 & 0.6385 & 0.6336 & 0.3665 & 0.3461 \\
\hline & 20 & 20 & 20 & 20 & 20 & 19 & 12 & 20 & 20 & 20 & 20 & 20 \\
\hline \multirow[t]{3}{*}{$\overline{L A}$} & 0.20225 & -0.21025 & 0.35913 & 0.10063 & -0.36788 & 1 & -0.39756 & -0.41644 & -0.33871 & -0.34775 & -0.23565 & -0.37292 \\
\hline & 0.4063 & 0.3876 & 0.131 & 0.6819 & 0.1212 & 0 & 0.226 & 0.0761 & 0.156 & 0.1446 & 0.3314 & 0,1158 \\
\hline & 19 & 19 & 19 & 19 & 19 & 19 & 11 & 19 & 19 & 19 & 19 & 19 \\
\hline \multirow[t]{3}{*}{$\overline{F-T}$} & -0.58439 & 0.28632 & -0.6528 & -0.13827 & 0.19899 & -0.39756 & 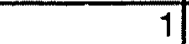 & 0.12455 & 0.71913 & 0.44226 & 0.43973 & 0.32463 \\
\hline & 0.046 & 0.3669 & 0.0214 & 0.6683 & 0.5353 & 0.226 & 0 & 0.6997 & 0.0084 & 0.15 & 0.1526 & 0.3032 \\
\hline & 12 & 12 & 12 & 12 & 12 & 11 & 12 & 12 & 12 & 12 & 12 & 12 \\
\hline \multirow[t]{3}{*}{$\mathrm{MG}$} & 0.05871 & 0.20545 & -0.10864 & 0.40689 & 0.05525 & -0.41644 & 0.12455 & 1 & 0.32261 & 0.0703 & 0.37509 & -0.01538 \\
\hline & 0.8004 & 0.3716 & 0.6392 & 0.075 & 0.817 & 0.0761 & 0.6997 & 0 & 0.1538 & 0.762 & 0.0938 & 0.9472 \\
\hline & 21 & 21 & 21 & 20 & 20 & 19 & 12 & 21 & 21 & 21 & 21 & 21 \\
\hline \multirow[t]{3}{*}{ T_ACID } & -0.08972 & 0.70343 & -0.63892 & 0.00952 & 0.11193 & -0.33871 & 0.71913 & 0.32261 & 1 & 0.66525 & 0.89292 & 0.1802 \\
\hline & 0.699 & 0.0004 & 0.0018 & 0.9682 & 0.6385 & 0.156 & 0.0084 & 0.1538 & 0 & 0.001 & 0.0001 & 0.4344 \\
\hline & 21 & 21 & 21 & 20 & 20 & 19 & 12 & 21 & 21 & 21 & 21 & 21 \\
\hline \multirow[t]{3}{*}{ P_200 } & 0.05221 & 0.48816 & -0.33827 & -0.05069 & -0.11354 & -0.34775 & 0.44226 & 0.0703 & 0.66525 & 1 & 0.25789 & 0.78597 \\
\hline & 0.8222 & 0.0248 & 0.1336 & 0.8319 & 0.6336 & 0.1446 & 0.15 & 0.762 & 0.001 & 0 & 0.2591 & 0.0001 \\
\hline & 21 & 21 & 21 & 20 & 20 & 19 & 12 & 21 & 21 & 21 & 21 & 21 \\
\hline \multirow[t]{3}{*}{ M_200 } & -0.14758 & 0.61593 & -0.62283 & 0.04289 & 0.21331 & -0.23565 & 0.43973 & 0.37509 & 0.89292 & 0.25789 & 1 & -0.24075 \\
\hline & 0.5232 & 0.003 & 0.0026 & 0.8575 & 0.3665 & 0.3314 & 0.1526 & 0.0938 & 0.0001 & 0.2591 & 0 & 0.2931 \\
\hline & 21 & 21 & 21 & 20 & 20 & 19 & 12 & 21 & 21 & 21 & 21 & 21 \\
\hline \multirow[t]{3}{*}{$\overline{\text { RATIO }}$} & -0.11676 & 0.1469 & -0.22344 & 0.00236 & -0.22235 & -0.37292 & 0.32463 & -0.01538 & 0.1802 & 0.78597 & -0.24075 & 1 \\
\hline & 0.6142 & 0.5252 & 0.3302 & 0.9921 & 0.3461 & 0.1158 & 0.3032 & 0.9472 & 0.4344 & 0.0001 & 0.2931 & ol \\
\hline & 21 & 21 & 21 & 20 & 20 & 19 & 12 & 21 & 21 & 21 & 21 & 21 \\
\hline
\end{tabular}


B. Dolomite

\begin{tabular}{|c|c|c|c|c|c|c|c|c|c|c|c|c|}
\hline & IFV & PV & WI & $A B$ & SPG & LA & SUL & $M G$ & T_ACID & P_200 & TM_200 & IRATIO \\
\hline \multirow[t]{3}{*}{ IFV } & 1 & 0.83636 & -0.17435 & 0.65025 & -0.67087 & 0.13232 & 0.44441 & -0.3454 & 0.41405 & 0.15757 & 0.54152 & -0.42429 \\
\hline & 0 & 0.0001 & 0.4622 & 0.0026 & 0.0017 & 0.5892 & 0.0646 & 0.1745 & 0.0695 & 0.507 & 0.0137 & 0.0623 \\
\hline & 20 & 20 & 20 & 19 & 19 & 19 & 18 & 17 & 20 & 20 & 20 & 20 \\
\hline \multirow[t]{3}{*}{ PV } & 0.83636 & 1 & -0.6856 & 0.76523 & -0.74493 & 0.10716 & 0.6034 & -0.6527 & 0.44825 & 0.20234 & 0.55958 & -0.24888 \\
\hline & 0.0001 & 0 & 0.0008 & 0.0001 & 0.0003 & 0.6624 & 0.008 & 0.0045 & 0.0475 & 0.3923 & 0.0103 & 0.29 \\
\hline & 20 & 20 & 20 & 19 & 19 & 19 & 18 & 17 & 20 & 20 & 20 & 20 \\
\hline \multirow[t]{3}{*}{$W \mid$} & -0.17435 & -0.6856 & 1 & -0.53805 & 0.4624 & -0.00849 & -0.56742 & 0.75604 & -0.25533 & -0.1542 & -0.28601 & -0.11639 \\
\hline & 0.4622 & 0.0008 & 0 & 0.0175 & 0.0462 & 0.9725 & 0.014 & 0.0004 & 0.2773 & 0.5163 & 0.2215 & 0.6251 \\
\hline & 20 & 20 & 20 & 19 & 19 & 19 & 18 & 17 & 20 & 20 & 20 & 20 \\
\hline \multirow[t]{3}{*}{$A B$} & 0.65025 & 0.76523 & -0.53805 & 1 & -0.96817 & 0.42739 & 0.59233 & -0.31927 & 0.0092 & -0.21238 & 0.20439 & -0.43279 \\
\hline & 0.0026 & 0.0001 & 0.0175 & 0 & 0.0001 & 0.068 & 0.0096 & 0.2281 & 0.9702 & 0.3827 & 0.4013 & 0.0642 \\
\hline & 19 & 19 & 19 & 19 & 19 & 19 & 18 & 16 & 19 & 19 & 19 & 19 \\
\hline \multirow[t]{3}{*}{$S P G$} & -0.67087 & -0.74493 & 0.4624 & -0.96817 & $\overline{1}$ & -0.5287 & -0.58818 & 0.29564 & -0.05644 & 0.19434 & -0.26904 & 0.48014 \\
\hline & 0.0017 & 0.0003 & 0.0462 & 0.0001 & 0 & 0.02 & 0.0102 & 0.2663 & 0.8185 & 0.4253 & 0.2654 & 0.0375 \\
\hline & 19 & 19 & 19 & 19 & 19 & 19 & 18 & 16 & 19 & 19 & 19 & 19 \\
\hline \multirow[t]{3}{*}{$\overline{L A}$} & 0.13232 & 0.10716 & -0.00849 & 0.42739 & -0.5287 & 1 & -0.03362 & 0.41488 & -0.2046 & -0.28123 & -0.09973 & -0.30987 \\
\hline & 0.5892 & 0.6624 & 0.9725 & 0.068 & 0.02 & 0 & 0.8946 & 0.1101 & 0.4008 & 0.2435 & 0.6846 & 0.1967 \\
\hline & 19 & 19 & 19 & 19 & 19 & 19 & 18 & 16 & 19 & 19 & 19 & 19 \\
\hline \multirow[t]{3}{*}{ SUL } & 0.44441 & 0.6034 & -0.56742 & 0.59233 & -0.58818 & -0.03362 & 1 & -0.76433 & 0.41806 & 0.22345 & 0.51016 & -0.03427 \\
\hline & 0.0646 & 0.008 & 0.014 & 0.0096 & 0.0102 & 0.8946 & 0 & 0.0009 & 0.0843 & 0.3728 & 0.0305 & 0.8926 \\
\hline & 18 & 18 & 18 & 18 & 18 & 18 & 18 & 15 & 18 & 18 & 18 & 18 \\
\hline \multirow[t]{3}{*}{$M G$} & -0.3454 & -0.6527 & 0.75604 & -0.31927 & 0.29564 & 0.41488 & -0.76433 & 1 & -0.63132 & -0.45573 & -0.65587 & -0.12587 \\
\hline & 0.1745 & 0.0045 & 0.0004 & 0.2281 & 0.2663 & 0.1101 & 0.0009 & 0 & 0.0066 & 0.066 & 0.0043 & 0.6303 \\
\hline & 17 & 17 & 17 & 16 & 16 & 16 & 15 & 17 & 17 & 17 & 17 & 17 \\
\hline \multirow[t]{3}{*}{ T_ACID } & 0.41405 & 0.44825 & -0.25533 & 0.0092 & -0.05644 & -0.2046 & 0.41806 & -0.63132 & 1 & 0.86083 & 0.90262 & 0.20251 \\
\hline & 0.0695 & 0.0475 & 0.2773 & 0.9702 & 0.8185 & 0.4008 & 0.0843 & 0.0066 & 0 & 0.0001 & 0.0001 & 0.3918 \\
\hline & 20 & 20 & 20 & 19 & 19 & 19 & 18 & 17 & 20 & 20 & 20 & 20 \\
\hline \multirow[t]{3}{*}{ P_200 } & 0.15757 & 0.20234 & -0.1542 & -0.21238 & 0.19434 & -0.28123 & 0.22345 & -0.45573 & 0.86083 & 1 & 0.55796 & 0.54759 \\
\hline & 0.507 & 0.3923 & 0.5163 & 0.3827 & 0.4253 & 0.2435 & 0.3728 & 0.066 & 0.0001 & o) & 0.0106 & 0.0124 \\
\hline & 20 & 20 & 20 & 19 & 19 & 19 & 18 & 17 & 20 & 20 & 20 & 20 \\
\hline \multirow[t]{3}{*}{ M_200 } & 0.54152 & 0.55958 & -0.28601 & 0.20439 & -0.26904 & -0.09973 & 0.51016 & -0.65587 & 0.90262 & 0.55796 & 1 & -0.1328 \\
\hline & 0.0137 & 0.0103 & 0.2215 & 0.4013 & 0.2654 & 0.6846 & 0.0305 & 0.0043 & 0.0001 & 0.0106 & 이 & 0.5767 \\
\hline & 20 & 20 & 20 & 19 & 19 & 19 & 18 & 17 & 20 & 20 & 20 & 20 \\
\hline \multirow[t]{3}{*}{ RATIO } & -0.42429 & -0.24888 & -0.11639 & -0.43279 & 0.48014 & -0.30987 & -0.03427 & -0.12587 & 0.20251 & 0.54759 & -0.1328 & 1 \\
\hline & 0.0623 & 0.29 & 0.6251 & 0.0642 & 0.0375 & 0.1967 & 0.8926 & 0.6303 & 0.3918 & 0.0124 & 0.5767 & 이 \\
\hline & 201 & 20 & 20 & 19 & 19 & 19 & 18 & 17 & 20 & 20 & 20 & 20 \\
\hline
\end{tabular}




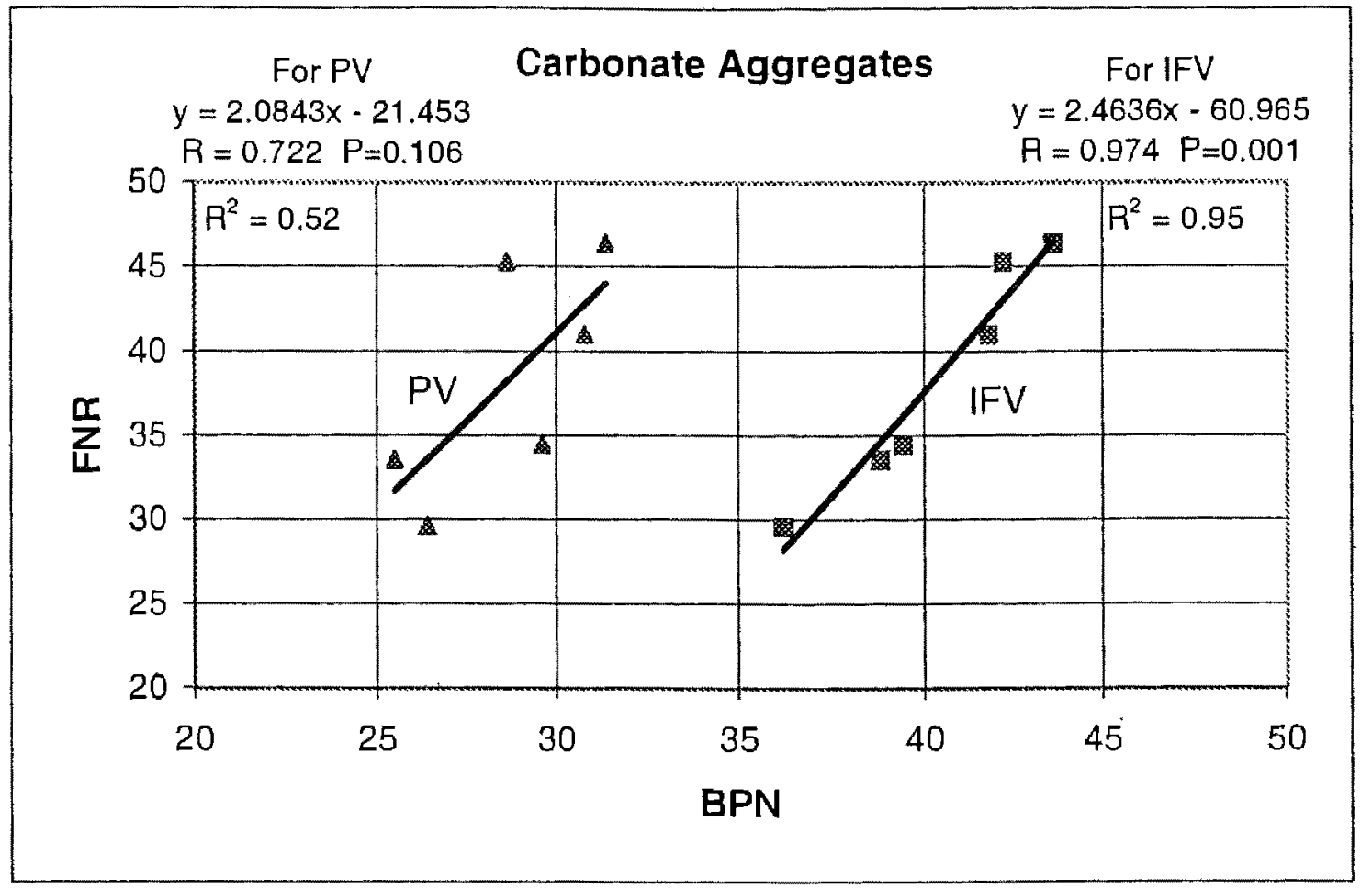

Figure 5-47. Correlation of Average Friction Number from ribbed trailer tire to IFV and PV determined from coupons composed of extracted core aggregates.

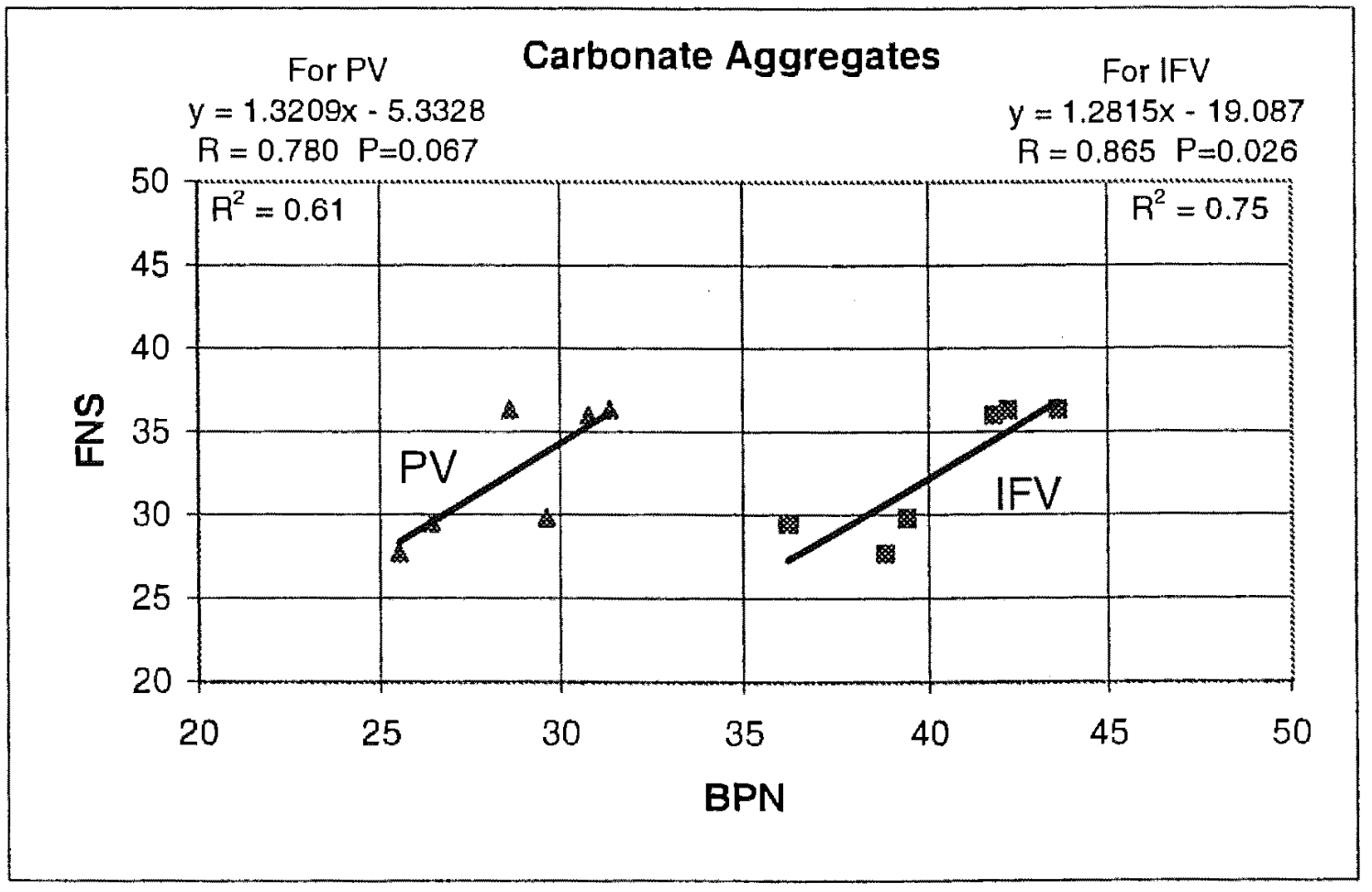

Figure 5-48. Correlation of Average Friction Number from smooth trailer tire to IFV and PV determined from coupons composed of extracted core aggregates. 


\subsection{Categorization of Carbonate Aggregates}

\subsubsection{Selection of critical parameters}

For bituminous wearing courses, aggregates are required to meet various demands such as strength, durability and skid resistance. For INDOT Specifications (1999), the strength and durability requirements are designated for aggregate samples used as pavement materials. In the current study, the frictional resistance capability of aggregate sources is indicated based on the correlation analysis between PV and other parameters.

For dolomite aggregates, from results of the correlation analysis (Tables 5-9A and 5-9B) and confidence interval (Appendix 1) between polished value (PV) and other aggregate properties, the parameters having $R>0.50$ are initial friction value (IFV) $\left(\mathrm{R}=0.836,0.625 \leq \rho \leq 0.933, \mathrm{R}^{2}=0.70\right)$, absorption $\left(\mathrm{R}=0.765,0.476 \leq \rho \leq 0.905, \mathrm{R}^{2}=\right.$ $0.59)$, specific gravity $\left(R=-0.745,0.896 \leq \rho \leq 0.440, R^{2}=0.56\right)$, sulfate soundness loss $\left(R=0.603,0.189 \leq \rho \leq 0.835, R^{2}=0.36\right)$, elemental Mg content $(R=-0.653,0.863 \leq \rho \leq$ $\left.0.251, R^{2}=0.43\right)$ and percent of acid insoluble residue smaller than $\# 200(R=0.560$, $0.156 \leq \rho \leq 0.803, R^{2}=0.31$ ) for dolomite aggregates.

For limestone aggregates, the parameters having $\mathrm{R}>0.50$ are total acid-insoluble residue $\left(R=0.703,0.390 \leq \rho \leq 0.871, R^{2}=0.49\right)$ and percent residue less than $\# 200$ $\left(\mathrm{R}=0.616,0.251 \leq \rho \leq 0.828, \mathrm{R}^{2}=0.38\right)$.

Some physical properties of aggregates are interrelated. For dolomite aggregates, absorption is highly correlated with specific gravity $(R=-0.968)$ and sulfate soundness loss $(\mathrm{R}=0.592)$. Elemental $\mathrm{Mg}$ content is well correlated with sulfate soundness loss $(\mathrm{R}=$ -0.764) and percent of acid insoluble residue smaller than \#200 ( $R=-0.656)$.

For limestone aggregates, only absorption among physical properties is well correlated with specific gravity $(R=-0.757)$. In the regression analysis, the dependant variables are IFV and PV, and independent variables are physical properties, elemental $\mathrm{Mg}$ content and acid insoluble residue. The independent variables should be independent of each other. 


\subsubsection{Regression Analysis of Laboratory Data}

In this research, a large quantity of data was generated based on laboratory analysis, INDOT records and the 1995 JTRP study. The goal of the statistical analysis was to determine aggregate properties that predict the performance of aggregates during in-service conditions with regard to skid resistance. Relevance of data was determined through correlation analysis, stepwise regression and multiple linear regression analyses.

PV was selected as the dependant variable and other laboratory data values were set as independent variables. Regression analysis was accomplished in three steps: First, the variables showing higher correlation were forced into regression and the relationship between PV and these laboratory variables were formulated separately for dolomite and limestone aggregates. Second, regression was conducted by stepwise method of the SAS program. PV and strongly related laboratory variables were chosen. Equations among these variables were generated separately for dolomite and limestone aggregates. Third, the dolomite and limestone data were combined into carbonate aggregates and analyzed collectively.

\subsubsection{Dolomite Aggregates}

Among the laboratory variables for dolomite aggregates, absorption, elemental $\mathrm{Mg}$ content and acid insoluble residue $<\# 200$ were selected as independent variables. Using multiple linear-regression, the relationship between PV and these variables was developed:

$$
\begin{aligned}
\mathrm{PV}(1)= & 38.0232+1.5568 \text { (Absorption) }-1.1750(\text { Mg content }) \\
& +0.3950(\text { Insoluble residue }<\# 200) \\
& \left(\mathrm{R}^{2}=0.779, \mathbf{P}<21.19 \%\right)
\end{aligned}
$$

Next, elemental Mg content was correlated with percent of acid insoluble residue less than \#200. The above equation after removal of acid insoluble residue is as follows: 


$$
\begin{aligned}
\mathrm{PV}(2)= & 46.0331+1.5645 \text { (Absorption) }-1.7651 \text { (Mg content }) \\
& \left(\mathrm{R}^{2}=0.747, \mathrm{P}<1.75 \%\right)
\end{aligned}
$$

Based on 5\% significance level, PV (2) was selected as the appropriate equation for dolomite aggregates. Considering the average $2.406 \%$ for absorption values in dolomite samples and the 25 of PV for the quality aggregates, the elemental $\mathrm{Mg}$ content corresponds to $14.1 \%$. This result indicates all ranges of dolomite $(6.6 \%$ to $13.2 \%$ elemental $\mathrm{Mg}$ ) have frictional resistance greater than $\mathrm{PV}=25$, with minimum $1.45 \%$ absorption.

For dolomite aggregates, the higher elemental $\mathrm{Mg}$ values correspond with the purer dolomite aggregates. The higher purity dolomites are poorer performer with regard to skid resistance. In the Indiana specifications (INDOT, 1999), a minimum 10.3\% elemental $\mathrm{Mg}$ content is required for carbonate aggregate sources based on a study performed in Illinois (Dierstein and LaCroix, 1984, 1990). It states: "The higher percentage of $\mathrm{MgO}$ corresponds with the higher frictional values". However, in the current study, the lower elemental $\mathrm{Mg}$ content corresponded with higher frictional values. Therefore, dolomites with less than $10.3 \% \mathrm{Mg}$ should be considered as an acceptable aggregate source if they pass the other specifications such as absorption and sulfate soundness loss. This is also consistent with elemental $\mathrm{Mg}$ content being inversely correlated with sulfate soundness loss $\left(R=-0.764, R^{2}=058\right)$. From Figure 5-49, $P V$ can be estimated using measured absorption and elemental $\mathrm{Mg}$ content data.

\subsubsection{Limestone Aggregates}

From the laboratory test variables of limestone aggregates, absorption, elemental $\mathrm{Mg}$ content and total insoluble residue were selected as independent variables. Using multiple linear-regression, the relationship between PV and these variables is as follows:

$$
\begin{aligned}
\mathrm{PV}(1)= & 21.3374+0.2733(\text { Absorption })-0.0376(\mathrm{Mg} \text { content }) \\
& +0.6161 \text { (Total insoluble residue }) \\
& \left(\mathrm{R}^{2}=0.499, \mathrm{P}<81.35 \%\right)
\end{aligned}
$$


Next, only total insoluble residue was considered as an independent variable because absorption and $\mathrm{Mg}$ content do not correlate well with PV. The relationship between PV and total insoluble residue is as follows:

$$
\begin{aligned}
\mathrm{PV}(2)= & 21.7006+0.6029(\text { Total insoluble residue }) \\
& \left(\mathrm{R}^{2}=0.495, \mathrm{P}<0.05 \%\right)
\end{aligned}
$$

Using 5\% significance level, PV (2) was selected as the appropriate equation for limestone aggregates. Considering the value of 25 for PV, the minimum required value yields a total insoluble residue of limestone aggregates equal to $5.47 \%$.

\subsubsection{Integration of dolomite and limestone data}

IFV and PV values and laboratory data for dolomite and limestone were analyzed collectively to predict the performance of carbonate aggregates in frictional resistance. Absorption, elemental $\mathrm{Mg}$ content and total insoluble residue were selected as independent variables by stepwise regression. The relationship between PV and these variables is as follows:

$$
\begin{aligned}
\mathrm{PV}(3)= & 19.4659+1.7212 \text { (Absorption) }+0.2105(\mathrm{Mg} \text { content }) \\
& +0.47863(\text { Total insoluble residue }) \\
& \left(\mathrm{R}^{2}=0.675, \mathrm{P}<0.61 \%\right)
\end{aligned}
$$

However, based on the distribution of elemental $\mathrm{Mg}$ content in carbonate aggregates, $\mathrm{PV}$ is more highly correlated with elemental $\mathrm{Mg}$ content by the $2^{\text {nd }}$ degree polynomial equation (Figure 5-50) than by the linear equation. The equation is as follows:

$$
\begin{aligned}
\mathrm{PV}(4)= & 19.5464+1.7129(\text { Absorption })+0.0164(\mathrm{Mg} \text { content })^{2} \\
& +0.5189(\text { Total insoluble residue }) \\
& \left(\mathrm{R}^{2}=0.683, \mathrm{P}<0.39 \%\right)
\end{aligned}
$$


The measured PV is compared with predicted equations PV (1), PV (2), PV (3) and PV (4) as shown in Tables 5-10A and 5-10B. According to the comparison of the squares of residuals, the squared values of residuals are similar for PV (1) through PV (4).

\subsubsection{Categorization of Polished Values}

According to historical perspectives, the tentative acceptance criteria for the minimum polished value permitted for surface course mixes is as follows. These limits are considered as a starting point for future refinement (Dierstein and LaCroix, 1990).

\begin{tabular}{cc} 
Minimum Polish Value & Quality \\
\hline 24 or less & Poor \\
25 to 30 & Marginal \\
31 or more & Good
\end{tabular}

According to the study on Alabama limestone and gravel aggregates as an asph It wearing course, BPN9 values were divided into 3 categories as following (Kandhal et al., 1993):

\begin{tabular}{cc} 
BPN9 Values & Categories \\
\hline Below 28 & Low \\
28 to 32 & Medium \\
32 or more & High
\end{tabular}

Also those authors noted that a general trend shows that as the insoluble residue percent (IR) increases the value of BPN9 also increases $(R=0.414)$. The relationship between two parameters was given by:

$$
\text { BPN9 }=29.7+0.02 *(\% \operatorname{IR}) \text {. }
$$




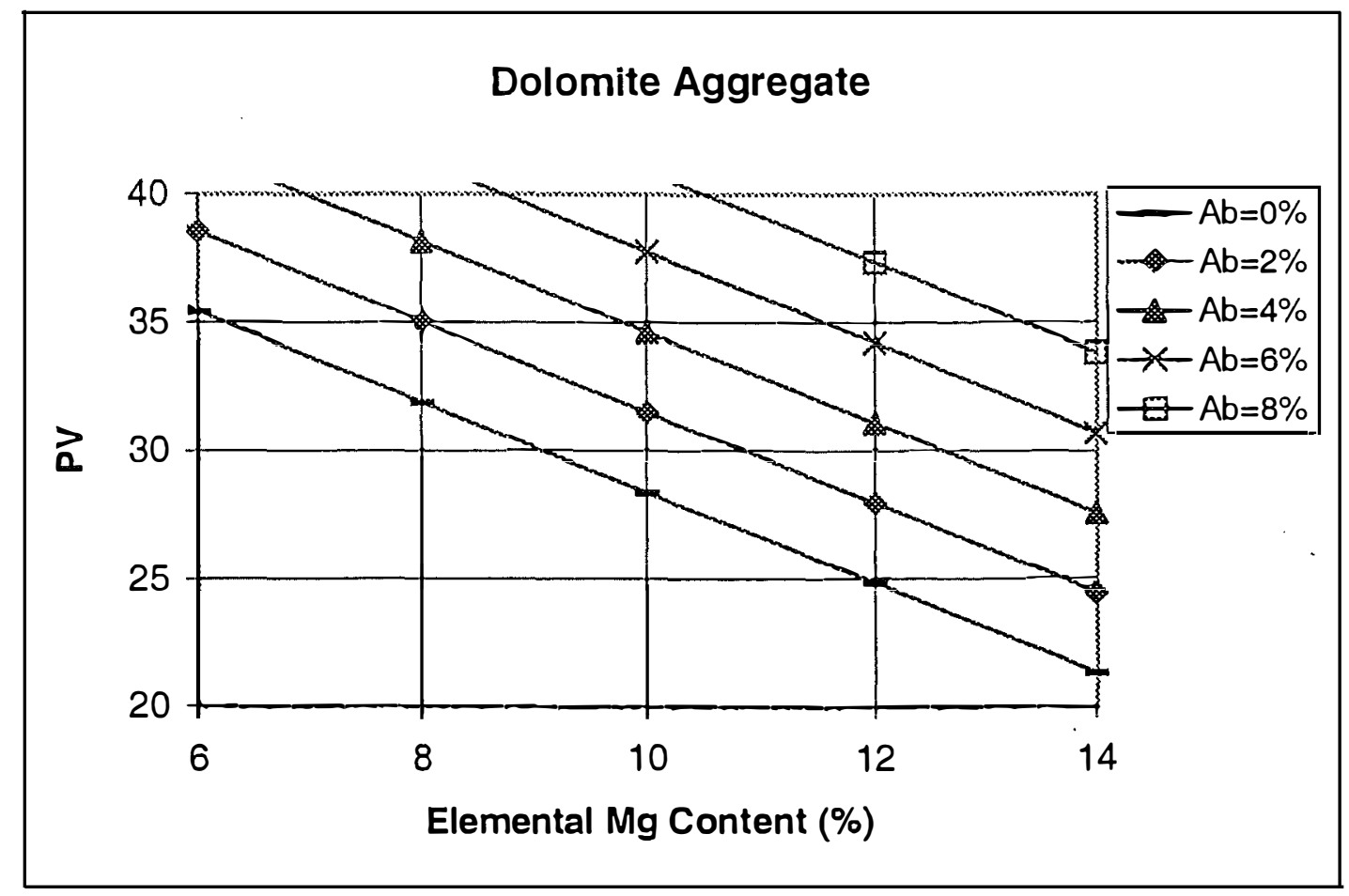

Figure 5-49. Prediction of polished value by absorption and elemental Mg content in dolomite aggregates

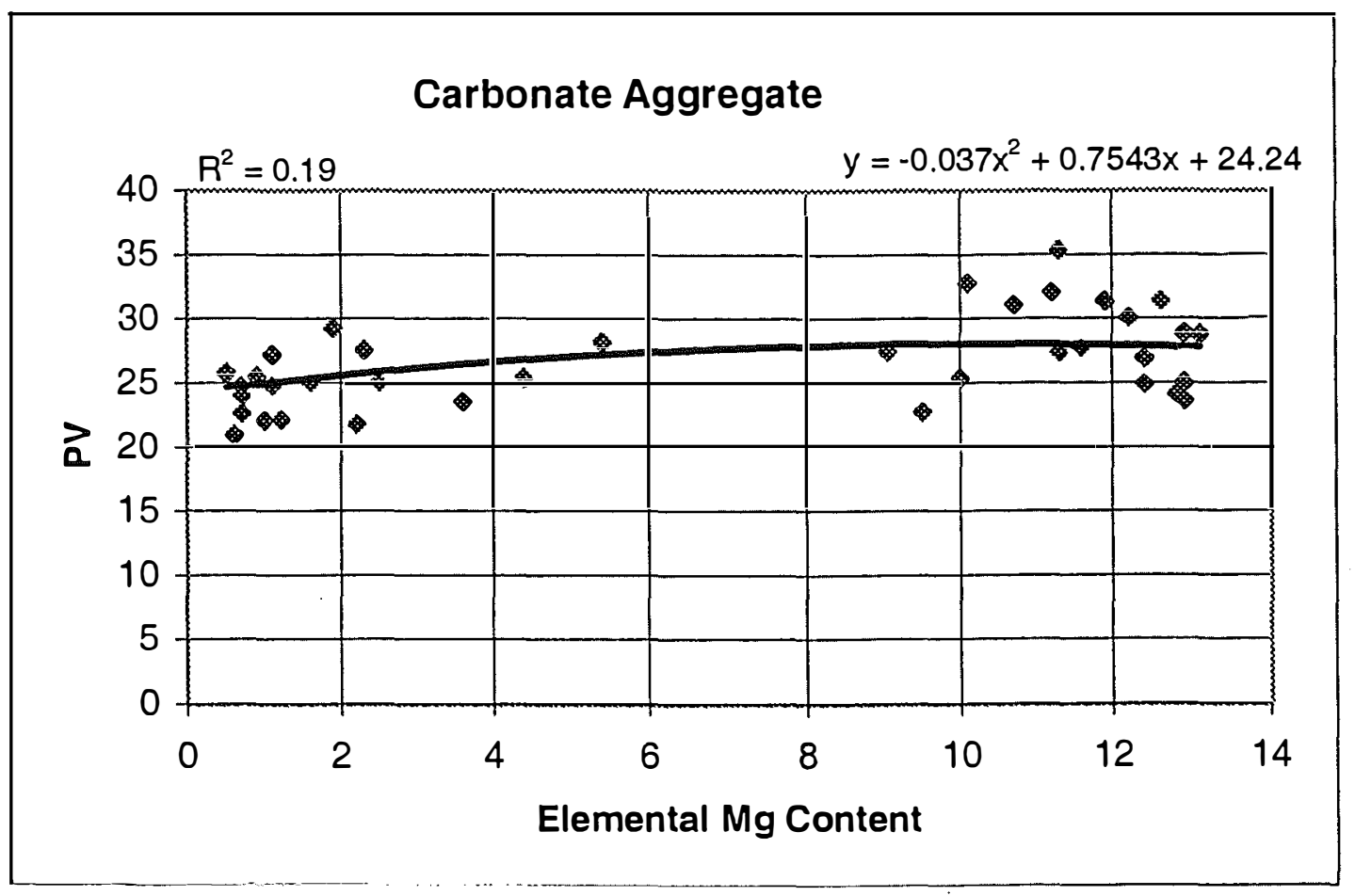

Figure 5-50. Non-linear relationship between polished value and elemental $\mathrm{Mg}$ content in carbonate Aggregates. 


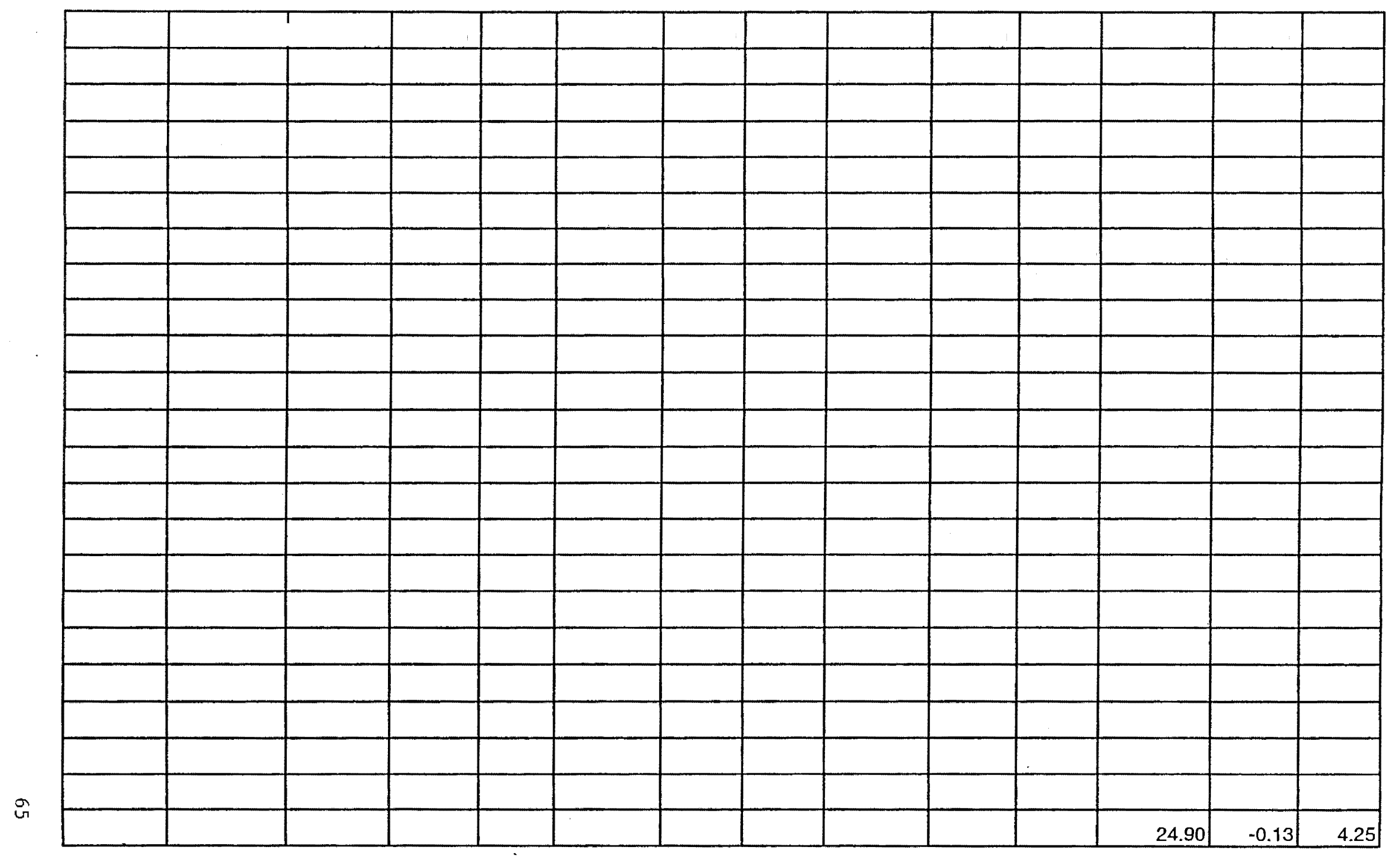




\section{B. Dolomite}

\begin{tabular}{|c|c|c|c|c|c|c|c|c|c|c|c|c|c|}
\hline Id. No. & Measured PV & Pre.PV(1) & Res.(1) & $S Q$ & Pre. PV (2) & Res.(2) & $S Q$ & Pre. PV (3) & Res.(3) & $S Q$ & Pre. PV (4) & Res.(4) & $S Q$ \\
\hline D-001 & 24.90 & 24.87 & 0.03 & 0.00 & 25.38 & -0.48 & 0.23 & 24.25 & 0.65 & 0.42 & 24.30 & 0.60 & 0.36 \\
\hline D-002 & 25.00 & 26.86 & -1.86 & 3.46 & 27.00 & -2.00 & 4.01 & 26.63 & -1.63 & 2.67 & 26.73 & -1.73 & 2.99 \\
\hline D-003 & 27.30 & 29.27 & -1.97 & 3.90 & 30.22 & -2.92 & 8.51 & 27.89 & -0.59 & 0.34 & 27.78 & -0.48 & 0.23 \\
\hline D-004 & 35.30 & 35.27 & 0.03 & 0.00 & 35.87 & -0.57 & 0.32 & 33.61 & 1.69 & 2.85 & 33.44 & 1.86 & 3.48 \\
\hline D-005 & 27.70 & 30.02 & -2.32 & 5.38 & 28.72 & -1.02 & 1.04 & 30.08 & -2.38 & 5.69 & 30.30 & -2.60 & 6.77 \\
\hline D-006 & 26.80 & 27.26 & -0.46 & 0.22 & 26.59 & 0.21 & 0.05 & 27.29 & -0.49 & 0.24 & 27.48 & -0.68 & 0.46 \\
\hline D-007 & 28.80 & 28.06 & 0.74 & 0.55 & 28.03 & 0.77 & 0.59 & 28.07 & 0.73 & 0.53 & 28.19 & 0.61 & 0.37 \\
\hline D-008 & 28.70 & 26.42 & 2.28 & 5.22 & 26.63 & 2.07 & 4.27 & 26.43 & 2.27 & 5.17 & 26.54 & 2.16 & 4.65 \\
\hline D-009 & 31.00 & 28.53 & 2.47 & 6.11 & 29.04 & 1.96 & 3.84 & 27.35 & 3.65 & 13.31 & 27.34 & 3.66 & 13.38 \\
\hline D.010 & 31.30 & 30.00 & 1.30 & 1.69 & 29.68 & 1.62 & 2.64 & 30.58 & 0.72 & 0.52 & 30.74 & 0.56 & 0.31 \\
\hline D-011 & 30.00 & 28.25 & 1.75 & 3.06 & 27.66 & 2.34 & 5.48 & 28.53 & 1.47 & 2.16 & 28.72 & 1.28 & 1.65 \\
\hline D-012 & 31.30 & 29.99 & 1.31 & 1.72 & 29.31 & 1.99 & 3.94 & 30.35 & 0.95 & 0.91 & 30.53 & 0.77 & 0.60 \\
\hline D-013 & 32.70 & & & & & & & & & & & & \\
\hline D-014 & 32.00 & 32.89 & -0.89 & 0.79 & 32.52 & -0.52 & 0.27 & 31.23 & 0.77 & 0.59 & 31.18 & 0.82 & 0.67 \\
\hline D-015 & 24.10 & 24.67 & -0.57 & 0.33 & 25.05 & -0.95 & 0.90 & 24.17 & -0.07 & 0.01 & 24.25 & -0.15 & 0.02 \\
\hline D-016 & 23.60 & 25.79 & -2.19 & 4.78 & 26.17 & -2.57 & 6.62 & 25.42 & -1.82 & 3.32 & 25.50 & -1.90 & 3.59 \\
\hline D-017 & 24.90 & 24.55 & 0.35 & 0.12 & 24.83 & 0.07 & 0.01 & 24.07 & 0.83 & 0.69 & 24.16 & 0.74 & 0.54 \\
\hline D-018 & 28.40 & & & & & & & & & & & & \\
\hline D-019 & 28.00 & & & & & & & & & & & & \\
\hline $\mathrm{D}-020$ & 28.10 & & & & & & & & & & & & \\
\hline Average & 28.50 & 28.29 & 0.00 & 2.33 & 28.29 & 0.00 & 2.67 & 27.87 & 0.42 & 2.46 & 27.95 & 0.35 & 2.51 \\
\hline
\end{tabular}


In the current study on Indiana limestones and the previous study on Indiana dolomites (Bruner, Choi and West, 1995), the BPN10 was used as the polished value. By the comparison between laboratory BPN and in-field AFN (Figures 5-47 and 5-48), $\mathrm{PV}=25$ may be considered as a minimum acceptable friction value for bituminous pavement aggregates. Carbonate aggregates (dolomite and limestone) are categorized into three groups as following:

\begin{tabular}{cc} 
Polished Values & Categories \\
\hline 24 or less & Low \\
25 to 30 & Medium \\
31 or more & High
\end{tabular}




\subsection{Sandstone Study}

\subsubsection{Selection of Sandstone Samples}

Samples were obtained from three sandstone sources in Illinois. They were designated as "S-001" and "S-002" obtained from the Aux Vases Sandstone that is predominantly a well sorted, calcareous, and very fine-grained quartz sandstone. The sample designated "S-003" is from the Rosiclare Sandstone. Rosiclare Sandstone is also calcareous sandstone and is considered as a member of the Aux Vases Sandstone.

The petrographic description for the calcareous sandstone is as follows (Hockett, 1987):

"A calcareous sandstone in which the clastic quartz grains are bound in a matrix of calcite. The angular to subangular quartz grains are from 0.1 to $0.5 \mathrm{~mm}$ in length and constitute about 60 percent of the material. The remainder is primarily a calcite cement, with grains 0.1 to $0.3 \mathrm{~mm}$ in length, with a trace of microcline, plagioclase, quartzite or chert, and dark carbonaceous matter."

\subsubsection{Physical Properties of Sandstone Samples}

The physical test data for sandstone samples were obtained from INDOT and the data are listed in Table 5-11.

According to the results of the physical properties of the sandstone, absorption ranges from $1.12 \%$ to $1.70 \%$, the specific gravity ranges from 2.584 to 2.624 and Los Angeles abrasion losses range from $26.24 \%$ to $28.66 \%$. Freeze and thaw loss in brine is $30.28 \%$ for S-001 and the freeze and thaw loss in water ranges from 0.72 to $8.12 \%$ for S002 and S-003.

\subsubsection{Magnesium Content and Acid-insoluble Residue of Sandstone Samples}

The elemental $\mathrm{Mg}$ content and the acid-insoluble residue of sandstone samples are listed in Table 5-12. 
Table 5-11. Physical properties of sandstone samples

\begin{tabular}{|c|c|c|c|c|}
\hline Id. No. & Absorption & $\begin{array}{c}\text { Specific } \\
\text { Gravity }\end{array}$ & $\begin{array}{c}\text { L.A. Abrasion } \\
\text { Loss }\end{array}$ & $\begin{array}{c}\text { Freeze/Thaw } \\
\text { Loss in water }\end{array}$ \\
\hline S-001 & - & - & - & $* 30.28 \%$ \\
\hline S-002 & $1.70 \%$ & 2.584 & $28.66 \%$ & $8.12 \%$ \\
\hline S-003 & $1.12 \%$ & 2.624 & $26.24 \%$ & $0.72 \%$ \\
\hline Average & $1.41 \%$ & 2.604 & $27.45 \%$ & $4.42 \%$ \\
\hline
\end{tabular}

- *: Freeze - thaw loss in brine.

Table 5-12. Elemental Mg content and acid-insoluble residue of sandstone samples

Unit: \%

\begin{tabular}{|c|c|c|c|c|c|c|c|}
\hline \multirow[b]{2}{*}{ Id. No. } & \multirow{2}{*}{$\begin{array}{l}\text { Elemental } \\
\text { Mg Content }\end{array}$} & \multirow{2}{*}{$\begin{array}{c}\text { Dolomite } \\
\text { Content }\end{array}$} & \multirow{2}{*}{$\begin{array}{l}\text { Calcite } \\
\text { Content }\end{array}$} & \multicolumn{4}{|c|}{ Acid-insoluble Residue } \\
\hline & & & & Total & $>\# 200$ & $<\# 200$ & $\begin{array}{l}>\# 200 \\
<\# 200\end{array}$ \\
\hline $\mathrm{S}-001$ & 2.5 & 7.94 & 75.5 & 16.60 & 9.40 & 7.20 & 1.31 \\
\hline S-002 & 0.4 & 1.27 & 39.8 & 58.94 & 56.91 & 1.98 & 28.7 \\
\hline S-003 & 0.4 & 1.27 & 35.4 & 63.36 & 63.06 & 0.30 & 210.0 \\
\hline Average & 1.1 & 3.49 & 50.2 & 46.30 & 43.12 & 3.16 & 80.0 \\
\hline
\end{tabular}

Table 5-13. IFV, PV and WI for sandstone samples

\begin{tabular}{|c|c|c|c|}
\hline Id. No, & IFV & PV & WI \\
\hline S-001 & 45.59 & 26.11 & 19.48 \\
\hline S-002 & 50.08 & 36.42 & 13.66 \\
\hline S-003 & 51.45 & 38.30 & 13.15 \\
\hline Average & 49.04 & 33.61 & 15.43 \\
\hline
\end{tabular}


Total acid-insoluble residue of sandstone samples ranged from 16.00 to $63.36 \%$. For percent of insoluble greater than $\# 200$, it ranged from 9.40 to $63.06 \%$ and for materials smaller than \#200 it ranged from 0.30 to $7.20 \%$. The ratio of percent material > \#200 to percent material <\#200 ranged from 1.31 to 210.0 . Based on the petrographic analysis, $\mathrm{S}-001$ is considered to be significantly more calcareous than the other two sandstone samples.

\subsubsection{Frictional Resistance Properties of Sandstone Samples}

Initial Friction Value (IFV) and Polished Value (PV) were measured on sandstone coupons using the British Pendulum tester. The IFV and PV for sandstone samples are listed in Table 5-13.

As shown in Tables 5-12 and 5-13, as the total insoluble residue increases, IFV and PV also increase but WI decreases. Also, as the ratio of percent material $>\# 200$ to percent material <\#200 increases, IFV and PV also increase but WI decreases. The reason that S-001 shows a lower PV than the other sandstones is that $\mathrm{S}-001$ is more properly described as a quartzose limestone. Also, as shown in Table 5-11, S-001 has higher elemental Mg content and a lower acid insoluble residue than do S-002 and S-003. 


\subsection{Variation of Frictional Resistance Values}

To evaluate the variation in frictional values between different test equipments in the current study, Polished Values were obtained from two different British Pendulum Testers: BPT1 (Purdue University equipment) and BPT2 (Alabama DOT equipment). The results are tabulated in Table 5-14 to Table 5-17 based on the various types of aggregate.

Table 5-14. Comparison of Polished Values of gravel aggregates obtained from BPT1 and BPT2.

\begin{tabular}{|c|c|c|c|}
\hline Id. No. & BPT1 & BPT2 & $\begin{array}{c}\text { Difference } \\
\text { (BPT1-BPT2) }\end{array}$ \\
\hline GR-1 & 26.29 & 25.94 & 0.35 \\
\hline GR-2 & 22.58 & 24.63 & -2.05 \\
\hline GR-3 & 23.47 & 25.97 & -2.50 \\
\hline GR-4 & 24.12 & 24.52 & -0.40 \\
\hline GR-5 & 22.94 & 25.44 & -2.50 \\
\hline GR-6 & 25.63 & 25.52 & 0.38 \\
\hline Average & 24.17 & 25.29 & -1.12 \\
\hline
\end{tabular}

As shown in Table 5-14, on average, the PV from BPT2 are slightly greater than those from BPT1.

Referring to Table 5-15 for limestone aggregates, the PV from BPT 1 and BPT2 showed some discrepancies between the two PVs. On average, the PV from BPT2 is slightly higher than from BPT1. 
Table 5-15. Polished Values of limestone aggregates from BPT1 and BPT2.

\begin{tabular}{|c|c|c|c|}
\hline Id. No. & BPT1 & BPT2 & Difference (BPT1-BPT2) \\
\hline L-001 & 28.14 & 26.03 & 2.11 \\
\hline L-002 & 24.72 & 26.83 & -2.11 \\
\hline L-003 & 22.69 & 24.12 & -1.43 \\
\hline L-004 & 23.49 & 25.28 & -1.79 \\
\hline L-005 & 21.67 & 23.95 & -2.28 \\
\hline L-006 & 20.87 & 21.63 & -0.76 \\
\hline L-007 & 25.50 & 25.50 & 0.00 \\
\hline L-008 & 24.97 & 28.56 & -3.59 \\
\hline L-009 & 27.40 & 26.50 & 0.90 \\
\hline L-010 & 25.39 & 22.22 & 3.17 \\
\hline L-011 & 25.39 & 26.04 & -0.65 \\
\hline L-012 & 27.51 & 20.75 & 6.76 \\
\hline L-013 & 29.24 & 25.81 & 3.43 \\
\hline L-014 & 25.00 & 26.03 & -1.03 \\
\hline L-015 & 27.12 & 26.98 & 0.14 \\
\hline L-016 & 24.72 & 27.14 & -2.42 \\
\hline L-017 & 25.73 & 29.94 & -4.21 \\
\hline L-018 & 22.55 & 27.51 & -4.96 \\
\hline L-019 & 23.95 & 22.13 & 1.82 \\
\hline L-020 & 22.05 & 26.24 & -4.19 \\
\hline L-021 & 22.01 & 20.87 & 1.14 \\
\hline Average & 24.77 & 25.24 & -0.47 \\
\hline
\end{tabular}


As shown in Table 5-16, PVs for dolomite aggregates measured by BPT1 and BPT2 typically show sizable differences. The first five listed (D-001B, D-003, D-007, D011 and D-020) are from the current study, evaluated at Purdue University (BPT1) and Alabama DOT (BPT2). The last two (D-001A and D-001C) are of a different nature.

Table 5-16. Polished Values of dolomite aggregates from BPT1 and BPT2.

\begin{tabular}{|c|c|c|c|}
\hline Id. No. & BPT1 & BPT2 & Difference (BPT1-BPT2) \\
\hline D-001B & 20.67 & 21.50 & -0.83 \\
\hline D-003 & 27.30 & 25.17 & 2.13 \\
\hline D-007 & 28.80 & 27.38 & 1.42 \\
\hline D-011 & 30.00 & 30.00 & 0.00 \\
\hline D-020 & 28.10 & 23.63 & 3.47 \\
\hline D-001A & 24.90 & 21.83 & 0.60 \\
\hline D-001C & 22.77 & 22.17 & 1.53 \\
\hline Average & 26.87 & 25.34 & 3.07 \\
\hline
\end{tabular}

D-001A is a dolomite coupon from the 1995 JTRP study and D-001C is from the current study with new epoxy material and the 1995 JTRP aggregate sample. There is a considerable discrepancy between these results for the same source. Factors involved are 1) a different location in the same aggregate quarry, 2) different epoxy materials used, and 3) a different technician conducting the test.

It is observed that PVs of BPT1 and BPT2 for D-001B and D-001C are more consistent than are those for D-001A.

The PVs for sandstone aggregates involving BPT1 and BPT2 are shown in Table 5-17. There is an average discrepancy between BPT1 and BPT2 of about 1.5 units. 
Table 5-17. Polished Values of sandstone aggregates from BPT1 and BPT2.

\begin{tabular}{|c|c|c|c|}
\hline Id. No. & BPT1 & BPT2 & Difference (BPT1-BPT2) \\
\hline S-001 & 26.11 & 25.35 & 0.76 \\
\hline S-002 & 36.42 & 34.08 & 2.34 \\
\hline S-003 & 38.30 & 36.81 & 1.49 \\
\hline Average & 33.61 & 32.08 & \\
\hline
\end{tabular}

with $\mathrm{R}=0.76$ as shown in Figure 5-51. 


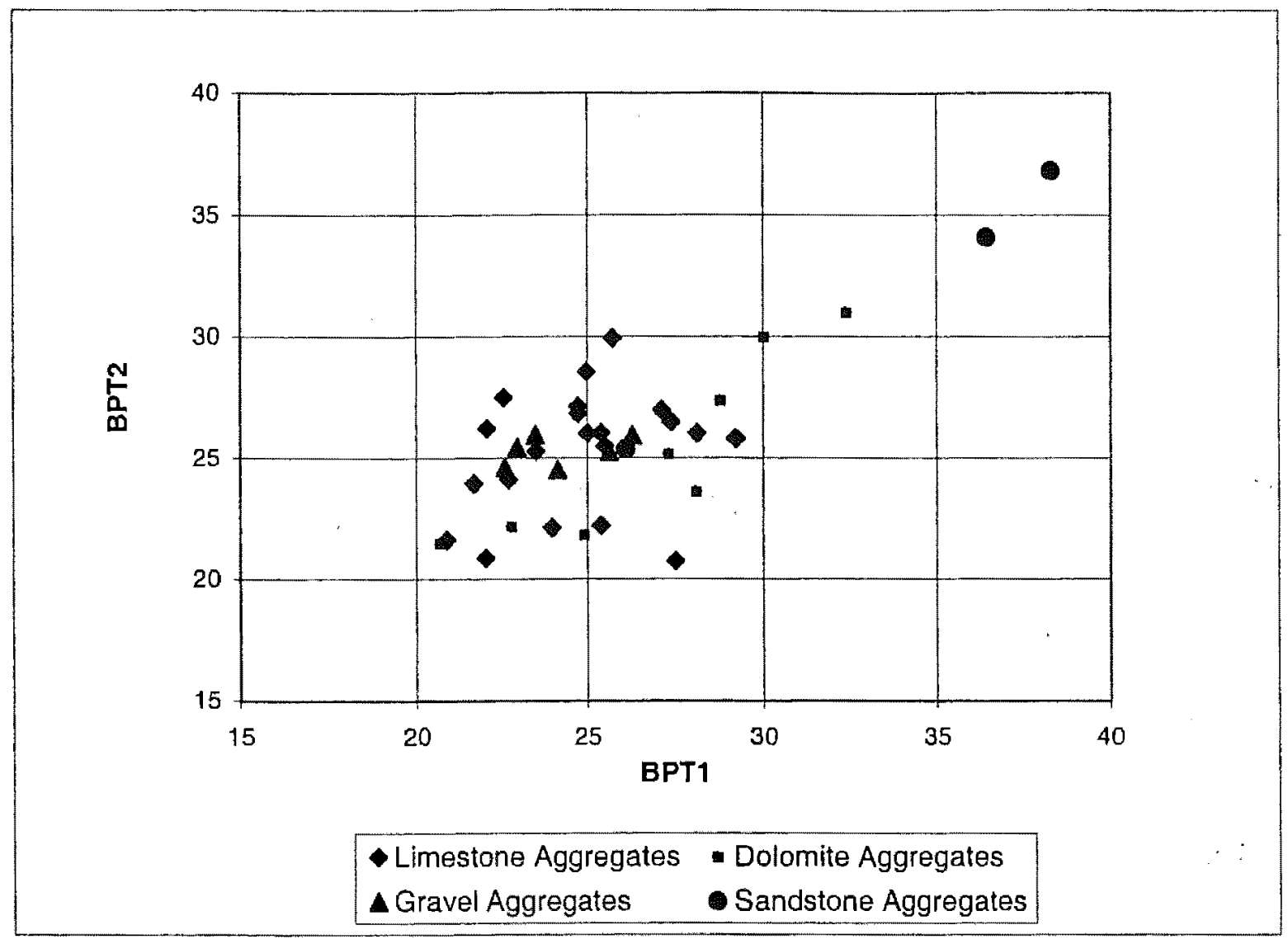

Figure 5-51. Comparison of Polished Values from BPT1 and BPT2 according to aggregate types 


\section{CONCLUSIONS}

The research results for this study, Project SPR-2206, "Development of a Procedure to Identify Aggregates for Bituminous Surfaces in Indiana," proved to be quite significant. Results of this study are combined with those of 1995 JTRP on dolomite aggregates. The conclusions of this combined study are presented below:

\section{Gravel Aggregates}

- Gravels in this study consisted primarily of sedimentary rocks including limestones and dolomites. The weighted PV of gravel samples ranged from 22.6 to 26.3. PV correlates best with freeze-thaw loss $\left(R=0.868, R^{2}=0.75\right)$. The other variables affecting the performance of gravel aggregates are absorption $\left(R=0.832, R^{2}=0.69\right)$, percentage of crushed gravel pieces $\left(R=0.804, R^{2}=0.65\right)$ and the percentage of metamorphic rocks present $\left(R=0.830, R^{2}=0.69\right)$.

- Higher percentages of crushed gravel pieces show higher frictional resistance.

\section{Carbonate Aggregates}

- The acid insoluble residue results provide valuable data related to frictional resistance of carbonate aggregates. This test should be performed on aggregates used in bituminous surface courses.

- The difference in mineral hardness within a rock piece yielding an uneven texture during polishing, has a major influence on aggregate performance. For example, quartz and calcite in a calcareous sandstone, calcite and insoluble residue (fine quartz and clay) in limestone, dolomite and calcite in a dolomitic limestone or calcareous dolomite, and an impure dolomite and impure limestone.

- Regarding geologic strata, for dolomite aggregates, the Kokomo Member shows the highest $\mathrm{PV}=33.3$, as the Kokomo Member is impure $(10.3 \% \mathrm{Mg}$ and $4.31 \%$ insoluble residue). By contrast, the Huntington Dolomite shows the lowest $\mathrm{PV}=25.4$ because 
Huntington Dolomite is very pure (12.4\% $\mathrm{Mg}$ and a lower 3.09\% insoluble residue). Among limestone aggregates, the Mississinewa Member shows the highest $\mathrm{PV}=28.1$ because the Mississinewa Member is very impure (5.40\% Mg and $12.72 \%$ insoluble residue). By contrast, the Brassfield Limestone shows the lowest $\mathrm{PV}=20.9$ because of its purity $(0.6 \% \mathrm{Mg}$ and $1.97 \%$ insoluble residue). The higher friction values in comparable dolomite aggregates may be due to dolomite's greater hardness.

- The important factors affecting the PV of dolomite aggregates are IFV $\left(R=0.836, \mathrm{R}^{2}\right.$ $=0.70)$, absorption $\left(R=0.765, R^{2}=0.59\right)$, specific gravity $\left(R=-0.745, R^{2}=0.56\right)$, sulfate soundness loss $\left(R=0.603, R^{2}=0.36\right)$, elemental $M g$ content $\left(R=-0.653 ; R^{2}=\right.$ $0.43)$ and percentage of insoluble residue smaller than $\# 200\left(R=0.560, R^{2}=0.31\right)$. Among the variables, IFV and PV, absorption, specific gravity and sulfate soundness loss, and the elemental $\mathrm{Mg}$ content and the percentage of insoluble residue are intercorrelated with each other. Therefore the most effective independent variables for dolomite aggregate performance are absorption and elemental $\mathrm{Mg}$ content.

- The important factors affecting the PV of the limestone aggregates are total insoluble residue $\left(R=0.703, R^{2}=0.49\right)$ and percent residue smaller than $\# 200\left(R=0.616, R^{2}=\right.$ 0.38). Both of these, insoluble residue and percent residue smaller than \#200, are intercorrelated with each other. Therefore the most effective independent factor for limestone aggregates is the total insoluble residue as it has the higher R-value.

- Considering dolomite and limestone aggregates collectively as carbonate aggregates, the important factors affecting the performance of these carbonate aggregates are absorption $\left(R=0.664, R^{2}=0.44\right)$, specific gravity $\left(R=-0.556, R^{2}=0.31\right)$, and elemental $\mathrm{Mg}$ content $\left(R=0.497, R^{2}=0.25\right)$. Absorption and specific gravity are highly dependant on each other. The total acid insoluble residue correlates well with both the percentage of insoluble residue $<\# 200$ and the percentage $>\# 200$. Therefore, the most effective variables for carbonate aggregates collectively are absorption, elemental $\mathrm{Mg}$ content and total insoluble residue.

- Multiple linear regression proved satisfactory in determining interactions between laboratory tests performed on dolomites and limestones in regard to friction values. 
Empirical equations were developed providing reasonable probability for estimating the laboratory friction values. These equations are as follows:

For dolomite aggregate at the 5\% significance level,

$$
\mathrm{PV}=46.0331+1.5645 \text { (Absorption) }-1.7651 \text { (Mg content) }
$$

For limestone aggregates at the $5 \%$ significance level,

$$
\mathrm{PV}=21.7006+0.6029 \text { (Total insoluble residue) }
$$

For carbonate aggregates at the $5 \%$ significance level,

$$
\begin{gathered}
\mathrm{PV}=19.5464+1.7129(\text { Absorption })+0.0164(\mathrm{Mg} \text { content })^{2} \\
+0.5189(\text { Total insoluble residue })
\end{gathered}
$$

- For dolomite aggregates, the higher elemental $\mathrm{Mg}$ values relate to higher purity dolomite materials. These dolomites have a lower friction resistance. Regarding INDOT specifications, a minimum $10.3 \%$ elemental $\mathrm{Mg}$ content is required for carbonate aggregates used for surface courses with intermediate traffic requirements. This is a consequence of the study of Illinois aggregates, which stated, "The higher percentage of $\mathrm{MgO}$ corresponds with the higher frictional values". However, in the current study, lower elemental $\mathrm{Mg}$ content values correspond to higher frictional values. Therefore dolomite aggregates with less than $10.3 \%$ elemental $\mathrm{Mg}$ should be considered as potential aggregate sources if these aggregates pass the other specifications such as absorption and soundness loss.

- For Class A aggregate (INDOT Standard Specifications, 1999) carbonate aggregates show an increase in frictional resistance with increasing absorption percentage. However, aggregates with greater than $5 \%$ absorption do not qualify as Class $\mathrm{A}$ aggregates and there is no indication that aggregates with greater than $5 \%$ absorption would have good friction values. Strength and durability problems are likely to occur above the $5 \%$ level. 


\section{Sandstone Aggregates}

- Based on the study of calcareous sandstones, as total insoluble residue (quartz, clay) increases, PV increases. Also, as the ratio of \#200 to -\#200 size insoluble residue increases, $\mathrm{PV}$ also increases

- Sandstone aggregates showed a higher average frictional resistance PV=33.61 than did carbonate aggregates (average $\mathrm{PV}=28.50$ for dolomite and average $\mathrm{PV}=24.77$ for limestone) because of the heterogeneity of calcareous sandstones. Quartz, calcite and clay provide this heterogeneity. 


\section{RECOMMENDATIONS}

Some recommendations on a procedure to identify a quality aggregates were made based on the overall results of the 1995 JTRP, SPR-2206 (Bruner, Choi and West, 1995) study and the current study.

- Crushed gravel aggregates and heterogeneous sandstone aggregates performed better in bituminous surface courses than did some crushed carbonate aggregates. These gravel and sandstone aggregates should be considered for use in a wearing course of bituminous pavements.

- Both impure limestones and impure dolomites performed better as bituminous surface courses than did either pure limestones or pure dolomites. These impure carbonates should be considered for use in wearing courses of bituminous pavements.

- Frictional resistance of dolomite aggregates can be predicted based on absorption and elemental $\mathrm{Mg}$ content. Frictional resistance of limestone aggregates can be also predicted from acid insoluble residue values. It is recommended, however, that the aggregates used must satisfy other aggregate specifications such as soundness loss (or freeze thaw) and maximum allowable absorption for Class A stone.

- The higher purity dolomites showed a lower friction resistance in the current study. Regarding INDOT specifications, a minimum $10.3 \%$ elemental Mg content is required for carbonate aggregates for bituminous surface courses with intermediate traffic requirements. However, based on the current study, dolomites with less than $10.3 \%$ elemental $\mathrm{Mg}$ should be considered for use in surface courses if these aggregates pass the other specifications such as absorption and soundness loss. Candidates should qualify as Class A materials, as high absorption and soundness loss may give rise to a strength or durability problem. Absorption values for Class $\mathrm{A}$ stone should be evaluated to select potential aggregates containing less than $10.3 \%$ $\mathrm{Mg}$, for possible use in bituminous overlays.

- Limited data on field and laboratory measurements (AFN and BPN) from the 1995 JTRP study suggest that a PV of 25 be considered as a minimum acceptable friction value for bituminous pavement aggregates with intermediate traffic requirements. It is 
recommended that some limestones be considered for bituminous surface courses, but the field performance of these limestones should to be verified.

- A discrepancy in PV values was observed between the two pieces of equipment used for British Pendulum testing. Before BPN is selected as a standard criterion for evaluating aggregate quality in Indiana, this standard method must be verified using new equipment and a detailed evaluation of inherent variations. PVs need to be evaluated on a continuing basis as PV can vary to some extent within the same aggregate source.

\section{IMPLEMENTATION SUGGESTIONS}

Based on the current study high purity dolomites show a lower friction resistance, or, impure dolomites (low $\mathrm{Mg}$ ) show a higher frictional value. Based on INDOT specifications, a minimum $10.3 \%$ elemental $\mathrm{Mg}$ content is required for carbonate aggregates when used for surface courses with intermediate traffic requirements. Therefore dolomites with less than $10.3 \%$ elemental $\mathrm{Mg}$ should be considered for bituminous surface courses with intermediate traffic requirements if these aggregates pass the other specifications such as absorption and soundness loss.

Carbonates with higher insoluble residue contents show a higher friction resistance than do purer carbonates with their low insoluble residue values. Data on insoluble residue content including grain size evaluation (\$200 size fraction vs. - \#200 size fraction) should also be determined. A data base for aggregates used in bituminous wearing courses should be compiled by INDOT which includes the insoluble residue content and absorption values. Elemental $\mathrm{Mg}$ and elemental $\mathrm{Ca}$ should also be determined.

A discrepancy in PV was observed between different pieces of test equipment for the British Pendulum test (Purdue University equipment vs. Alabama DOT equipment). Before BPN is selected as a standard criterion for evaluating aggregate quality in Indiana, the standard method must be developed using new equipment and a detailed evaluation of inherent variations. PVs need to be evaluated on a continuing basis because PV can vary even within the same aggregate source. 
Some impure limestones with a higher frictional value should be considered for surface courses of bituminous overlays. However, field performance of these limestones must be verified through field and laboratory evaluation prior to their use as overlays. 


\section{REFERENCE CITED}

American Association of State Highway and Transportation Officials, 1974, Sampling stone, slag, gravel, sand and stone block for use in highway materials, eleventh edition, T-2-74: Washington D.C.

American Association of State Highway and Transportation Officials, 1999, Procedure A, standard Test for Unconfined Freeze Thaw Testing of Aggregates, T 103: Washington D.C.

American Society for Testing and Materials, 1999, Standard practice for petrographic examination of aggregate for concrete. Vol. 04.02, C 295-98: American Society for Testing and Materials, Philadelphia.

American Society for Testing and Materials, 1999, Standard specification for agricultural liming materials, Vol. 04.01, C 602-90: American Society for Testing and Materials, Philadelphia, PA.

American Society for Testing and Materials, 1999, Standard practice for reducing field samples of aggregate to testing size, Vol. 04.02, C 702-87: American Society for Testing and Materials, Philadelphia, PA.

American Society for Testing and Materials, 1999, Standard practice for sampling aggregates. Vol. 04.08, D 75-87: American Society for Testing and Materials, Philadelphia, PA.

American Society for Testing and Materials, 1999, Standard test method for insoluble residue in carbonate aggregates, Vol. 04.02, D 3042-92: American Society for Testing and Materials, Philadelphia, PA. 
American Society for Testing and Materials, 1999, Standard test method for accelerated polishing of aggregates using the British Wheel, Vol. 04.03, D 3319-90: American Society for Testing and Materials, Philadelphia, PA, pp.

American Society for Testing and Materials, 1999, Test method for skid resistance of paved surfaces using a full scale tire, Vol. 04.03, E 274-90: American Society for Testing and Materials, Philadelphia, PA,

American Society for Testing and Materials, 1999, Standard method for using the British Pendulum tester, Vol. 04.03, E 303-83: American Society for Testing and Materials, Philadelphia, PA.

American Society for Testing and Materials, 1999, Soundness of Aggregates by use of Sodium Sulfate or Magnesium Sulfate, Vol. 04.02, C 88-99a: American Society for Testing and Materials, Philadelphia, PA.

American Society for Testing and Materials, 1999, Specific gravity and Absorption of Coarse Aggregates, Vol. 04.02, C 127-88: American Society for Testing and Materials, Philadelphia, PA.

Bruner, D.W., Choi, J.C. and West, T.R., 1995, Development of a Procedure to Identify . Aggregate for Bituminous Surface in Indiana, FHWA/N/JHRP, 95/11, Final Report, School of Civil Engineering, Purdue University, West Lafayette, IN, 177 pp.

Carr, D.D. and W.M. Webb, 1970, Sand and gravel resources of Indiana, Bulletin 42-D, Indiana Geological Survey.

Carr, D.D., French R.R., and Curtis, H.A., 1971, Crushed stone aggregate resources of Indiana, Bulletin 42-H, Indiana Geological Survey. 
Cummings, W.L., 1976, Properties of carbonate rock aggregate affecting the skid resistance of bituminous concrete pavement [Master's thesis]: New Brunswick, New Jersey, Rutgers University, 47 pp.

Dawson, T.A. and G.L. Carpenter, 1963, Underground storage of natural gas in Indiana, Special Report 1, Indiana Geological Survey, Bloomington, Indiana, 29 pp.

Dahir, S.H.M. and Mullen, W.G., 1971, Factors influencing aggregate skid-resistance properties, Highway Research Record 376, pp.136-148.

Deiss, C.F., 1952, Geologic formations on which and with which Indiana's roads are built, Circular No.1, Indiana Department of Conservation Geological Survey.

Dierstein, P.G. and J.E. LaCroix, 1990, A summary of the Illinois skid-accident reduction program, Aggregates and Skid Resistance, FHWA/NJ 89-008-7110, New Jersey Department of Transportation.

Dierstein, P.G., and J.E. LaCroix, 1984, A summary of the Illinois skid-accident reduction program: Illinois Department of Transportation, Bureau of Materials and Physical Research, $131 \mathrm{pp}$.

Hockett, R.B., 1987, Rosiclare sandstone as a skid-resistant aggregate for bituminous surface course mixtures. Unpublished report for IDOH Skid-Accident Reduction Committee, Indianapolis, Indiana, 7 pp.

Indiana Department of Transportation, 1999, Standard Specification, $888 \mathrm{pp}$.

Kandhal, P.S., Parker, F. and Bishara, E.A., 1993, Evaluation of Alabama Limestone Aggregate for Asphalt Wearing Course. Transportation Research record 1418 pp. $12-21$. 
McGregor, D.J., 1960, Gravels of Indiana, Report of Progress No. 17, Indiana Geological Survey.

Mullen, W.G., 1974, Prediction of Pavement Skid resistance from Laboratory Tests. Transportation Research Record 523, pp. 40-55.

Mullen, W.G., Dahir, S.M. and Madani, N.F., 1974, Laboratory Evaluation of Aggregates, Aggregate Blends, and Bituminous Mixes for Polish Resistance. Transportation Research Record 523, pp. 56-64.

Rooney, L.F., 1970, High-calcium limestone and high-magnesium dolomite resources of Indiana. Bulletin 42-B, Indiana Geological Survey, 1970.

Russell, S.J., 1972, Physical, chemical, and petrographic properties affecting the skid resistance of carbonate aggregates in Illinois class 111 bituminous concrete pavements [Master's thesis]: Urbana, Illinois, University of Illinois, 43 pp.

Senior, S.A., and Rogers, C.A., 1991, Laboratory tests for predicting coarse aggregate performance in Ontario, in Proceedings, Transportation Research Board, 70th annual meeting, Washington D.C., Ministry of Transportation, Downsview, Ontario, Canada, 29 pp.

Shakoor, A., and West, T.R., 1979, Petrographic examination of aggregates used in bituminous overlays for Indiana pavements as related to their polishing characteristics. Thirteenth Annual Highway Geology Symposium: Portland, Oregon, pp. 185-210.

Shaver, R.H., Ault, C.H., and fifteen others, 1986, Compendium of rock-unit stratigraphy in Indiana, Indiana Geological Survey, Bulletin 59. 
Sherwood, W.C., Mahone, D.C. and Eaton, L.S., 1999, The effect of aggregate type and mix design on wet pavement skid resistance. Proceedings, $50^{\text {th }}$ Highway Geology Symposium, pp. 176-189.

Shupe J.W., 1958, A laboratory investigation of factors affecting the slipperiness of bituminous paving mixtures, Ph.D thesis, West Lafayette, Indiana, Purdue University, $193 \mathrm{pp}$.

Shupe, J.W., 1960, Pavement slipperiness, Highway Engineering Handbook, K. B. Woods Edition, 1st edition: New York, McGraw-Hill Book Company, Inc., pp. 20.1-20.27.

West, T.R., Johnson, R.B., and Smith, N.M., 1970, Tests for evaluating gradation of base course aggregates: National Cooperative Highway Research Program SBN 30901885-4, Report 93, Highway Research Board, Washington D.C., 22 pp.

West, T.R., 1995, Evolution of a Technique: Petrography of aggregates for Concrete and Bituminous Pavements. Proceeding, $46^{\text {th }}$ Highway Geology Symposium, pp.166176. May, Charleston, West Virginia. 
APPENDICIES 
Appendix 1. Confidence Interval for R-value (Fisher's Transformation)

A. Limestone

\begin{tabular}{|c|c|c|c|c|c|c|c|c|}
\hline Variables & R-value & $z^{\prime}$ & $\mathrm{n}$ & $\sigma\left(z^{\prime}\right)$ & $\mathrm{u}_{\mathrm{z}}(\mathrm{min})$ & $u_{z^{\prime}}(\max )$. & $\rho(\min )$. & $\rho(\max )$. \\
\hline IFV - PV & 0.323 & 0.335 & 21 & 0.236 & -0.127 & 0.797 & -0.126 & 0.662 \\
\hline IFV - WI & 0.663 & 0,798 & 21 & 0.236 & 0.336 & 1.260 & 0.324 & 0.851 \\
\hline IFV $\cdot A B$ & 0,103 & 0.103 & 20 & 0.243 & -0.372 & 0.579 & -0.356 & 0.522 \\
\hline IFV - SPG & -0.203 & -0.206 & 20 & 0.243 & -0.681 & 0.270 & -0.592 & 0.263 \\
\hline IFV - LA & 0.202 & 0.205 & 19 & 0.250 & -0.285 & 0.695 & -0.278 & 0.601 \\
\hline$I F V-F-T$ & -0.584 & -0.669 & 12 & 0.333 & -1.322 & -0.015 & -0.867 & -0.015 \\
\hline IFV - MG & 0.059 & 0.059 & 21 & 0.236 & -0.403 & 0.521 & -0.382 & 0.479 \\
\hline IFV - T_ACID & -0.090 & -0.090 & 21 & 0.236 & -0.552 & 0.372 & -0.502 & 0.356 \\
\hline IFV - P_200 & 0.052 & 0.052 & 21 & 0.236 & -0.410 & 0.514 & -0.388 & 0.473 \\
\hline IFV - M_200 & -0.148 & -0.149 & 21 & 0.236 & -0.611 & 0.313 & -0.545 & 0.303 \\
\hline IFV - RATIO & -0.117 & -0.118 & 21 & 0.236 & -0.580 & 0.344 & -0.522 & 0.331 \\
\hline$P V-W I$ & -0.495 & -0.543 & 21 & 0.236 & -1.005 & -0.081 & -0.764 & -0.081 \\
\hline$P V-A B$ & 0.047 & 0.047 & 20 & 0.243 & -0.428 & 0.522 & -0.404 & 0.480 \\
\hline$P V$ - SPG & -0.073 & -0.073 & 20 & 0.243 & -0.548 & 0.402 & -0.499 & 0.382 \\
\hline PV - LA & -0.210 & -0.213 & 19 & 0.250 & -0.703 & 0.277 & -0.606 & 0.270 \\
\hline$P V-F-T$ & 0.286 & 0.294 & 12 & 0.333 & -0.359 & 0.948 & -0.344 & 0.739 \\
\hline$P V-M G$ & 0.205 & 0.208 & 21 & 0.236 & -0.254 & 0.670 & -0.249 & 0.585 \\
\hline PV - T ACID & 0.703 & 0.873 & 21 & 0.236 & 0.411 & 1.335 & 0.390 & 0.871 \\
\hline PV - P 200 & 0.488 & 0.533 & 21 & 0.236 & 0.071 & 0.995 & 0.071 & 0.760 \\
\hline$P V-M \_200$ & 0.616 & 0.719 & 21 & 0.236 & 0.257 & 1.181 & 0.251 & 0.828 \\
\hline PV - RATIO & 0.147 & 0.148 & 21 & 0.236 & -0.314 & 0.610 & -0.304 & 0.544 \\
\hline$W I-A B$ & 0.056 & 0.056 & 20 & 0.243 & -0.419 & 0.531 & -0.396 & 0.486 \\
\hline WI - SPG & -0.127 & -0.128 & 20 & 0.243 & -0.603 & 0.348 & -0.539 & 0.334 \\
\hline WI - LA & 0.359 & 0.376 & 19 & 0.250 & -0.114 & 0.866 & -0.114 & 0.699 \\
\hline WI - F-T & -0.653 & -0.781 & 12 & 0.333 & -1.434 & -0.127 & -0.892 & -0.126 \\
\hline$W I-M G$ & -0.109 & -0.109 & 21 & 0.236 & -0.571 & 0.353 & -0.516 & 0.339 \\
\hline WI-T_ACID & -0.639 & -0.756 & 21 & 0.236 & -1.218 & -0.295 & -0.839 & -0.286 \\
\hline$W 1-P=200$ & -0.338 & -0.352 & 21 & 0.236 & -0.814 & 0.110 & -0.672 & 0.110 \\
\hline$W I-M \_200$ & -0.623 & -0.730 & 21 & 0.236 & -1.192 & -0.268 & -0.831 & -0.262 \\
\hline WI - RATIO & -0.223 & -0.227 & 21 & 0.236 & -0.689 & 0.235 & -0.597 & 0.231 \\
\hline
\end{tabular}

$z^{\prime}=0.5^{\star} \ln [(1+R) /(1-R)]$

$\sigma\left(z^{\prime}\right)=1 /$ sqrit $(n-3) \quad n=$ number of samples

$u_{z^{\prime}}=z^{\prime}+1-z_{(05 \alpha)}{ }^{*} \sigma\left(z^{\prime}\right) \quad z_{(0.5 \alpha)}=1.96$ for $95 \%$ confidence interval 
B. Dolomite

\begin{tabular}{|c|c|c|c|c|c|c|c|c|}
\hline Variables & r-value & $z^{\prime}$ & $n$ & $\sigma\left(z^{\prime}\right)$ & $\mathrm{u}_{\mathrm{z}^{\prime}}(\min )$. & $\mathrm{u}_{z^{\prime}}(\max )$. & $\rho(\min )$. & $\rho(\max )$. \\
\hline$I F V$ - PV & 0.836 & 1.208 & 20 & 0.243 & 0.732 & 1.683 & 0.625 & 0.933 \\
\hline$|F V-W|$ & -0.174 & -0.176 & 20 & 0.243 & -0.651 & 0.300 & -0.572 & .291 \\
\hline$I F V-A B$ & 0.650 & 0.775 & 19 & 0.250 & 0.285 & 1.265 & 0.278 & 0.853 \\
\hline IFV - SPG & -0.671 & -0.813 & 19 & 0.250 & -1.303 & -0.323 & -0.862 & -0.312 \\
\hline IFV - LA & 0.132 & 0.133 & 19 & 0.250 & -0.357 & 0.623 & -0.343 & 0.553 \\
\hline IFV - SUL & 0.444 & 0.477 & 18 & 0.258 & -0.029 & 0.983 & -0.029 & 0.754 \\
\hline IFV - MG & -0.345 & -0.360 & 17 & 0.267 & -0.884 & 0.164 & -0.708 & 0.163 \\
\hline IFV - T_ACID & 0.414 & 0.440 & 20 & 0.243 & -0.035 & 0.916 & -0.035 & 0.724 \\
\hline IFV - P_200 & 0.158 & 0.159 & 20 & 0.243 & -0.316 & 0.635 & -0.306 & 0.561 \\
\hline IFV-M_200 & 0.542 & 0.607 & 20 & 0.243 & 0.132 & 1.082 & 0.131 & 0.7 .94 \\
\hline IFV - RATIO & -0.424 & -0.453 & 20 & 0.243 & -0.928 & 0.023 & -0.730 & 0.023 \\
\hline$P V-W I$ & -0.686 & -0.840 & 20 & 0.243 & -1.316 & -0.365 & -0.866 & -0.350 \\
\hline$P V-A B$ & 0.765 & 1.008 & 19 & 0.250 & 0.518 & 1.498 & 0.476 & 0.905 \\
\hline$P V-S P G$ & -0.745 & -0.962 & 19 & 0.250 & -1.452 & -0.472 & -0.896 & -0.440 \\
\hline$P V$ - LA & 0.107 & 0.107 & 19 & 0.250 & -0.383 & 0.597 & -0.365 & .535 \\
\hline PV - SUL & 0.603 & 0.698 & 18 & 0.258 & 0.192 & 1.204 & 0.189 & 0.835 \\
\hline$P V-M G$ & -0.653 & -0.781 & 17 & 0.267 & -1.304 & -0.257 & -0.863 & -0.251 \\
\hline PV - T_ACID & 0.448 & 0.482 & 20 & 0.243 & 0.007 & 0.958 & 0.007 & 0.743 \\
\hline PV - P_200 & 0.202 & 0.205 & 20 & 0.243 & -0.271 & 0.680 & -0.264 & 0.592 \\
\hline$P V-M \_200$ & 0.560 & 0.633 & 20 & 0.243 & 0.157 & 1.108 & 0.156 & 0.803 \\
\hline PV - RATIO & -0.249 & -0.254 & 20 & 0.243 & -0.730 & 0.221 & -0.623 & 0.217 \\
\hline$W I-A B$ & -0.538 & -0.601 & 19 & 0.250 & -1.091 & -0.111 & -0.797 & -0.111 \\
\hline$W I$ - SPG & 0.462 & 0.500 & 19 & 0.250 & 0.010 & 0.990 & 0.010 & 0.757 \\
\hline$W I-L A$ & -0.008 & -0.008 & 19 & 0.250 & -0.498 & 0.482 & -0.461 & 0.448 \\
\hline WI - SUL & -0.567 & -0.643 & 18 & 0.258 & -1.149 & -0.137 & -0.817 & -0.136 \\
\hline$W I-M G$ & 0.756 & 0.987 & 17 & 0.267 & 0.463 & 1.511 & 0.433 & 0.907 \\
\hline WI - T_ACID & -0.255 & -0.261 & 20 & 0.243 & -0.736 & 0.215 & -0.627 & 0.211 \\
\hline$W I-P \_200$ & -0.154 & -0.155 & 20 & 0.243 & -0.631 & 0.320 & -0.558 & 0.310 \\
\hline$W I$ - M_200 & -0.286 & -0.294 & 20 & 0.243 & -0.770 & 0.181 & -0.647 & 0.179 \\
\hline WI - RATIO & -0.116 & -0.117 & 20 & 0.243 & -0.592 & 0.359 & -0.531 & 0.344 \\
\hline
\end{tabular}


C. Gravel

\begin{tabular}{|c|c|c|c|c|c|c|c|c|}
\hline Variables & r-value & $z^{\prime}$ & $n$ & $\sigma\left(z^{\prime}\right)$ & $\mathrm{u}_{z^{\prime}}(\min )$. & $\mathrm{u}_{z^{\prime}}(\max )$ & $\rho(\min )$. & $\rho(\max )$. \\
\hline IFV - PV & 0.837 & 1.211 & 6 & 0.577 & 0.079 & 2.343 & 0.079 & 0.982 \\
\hline $\mid F V-W I$ & 0.924 & 1.616 & 6 & 0.577 & 0.484 & 2.747 & 0.450 & 0.992 \\
\hline$I F V-A B$ & 0.893 & 1.437 & 6 & 0.577 & 0.305 & 2.568 & 0.296 & 0.988 \\
\hline IFV - SPG & -0.372 & -0.391 & 6 & 0.577 & -1.522 & 0.741 & -0.909 & 0.630 \\
\hline IFV - LA & 0.563 & 0.637 & 6 & 0.577 & -0.494 & 1.769 & -0.458 & 0.943 \\
\hline IFV $-F-T$ & 0.846 & 1.242 & 6 & 0.577 & $0 . \uparrow 10$ & 2.374 & 0.110 & 0.983 \\
\hline $1 F V-19 \%$ & -0.178 & -0.180 & 6 & 0.577 & -1.312 & 0.952 & -0.865 & 0.741 \\
\hline IFV - META\% & 0.506 & 0.557 & 6 & 0.577 & -0.574 & 1.689 & -0.518 & 0.934 \\
\hline IFV - LS\% & -0.031 & -0.031 & 6 & 0.577 & -1.163 & 1.101 & -0.822 & 0.801 \\
\hline IFV - DOL \% & -0.006 & -0.006 & 6 & 0.577 & -1.138 & 1.126 & -0.814 & 0.810 \\
\hline IFV - OS $\%$ & -0.025 & -0.025 & 6 & 0.577 & -1.157 & 1.107 & -0.820 & 0.803 \\
\hline IFV - CRUSH $\%$ & 0.890 & 1.422 & 6 & 0.577 & 0.290 & 2.554 & 0.282 & 0.988 \\
\hline PV-WI & 0.565 & 0.640 & 6 & 0.577 & -0.491 & 1.772 & -0.455 & 0.944 \\
\hline$P V-A B$ & 0.832 & 1.195 & 6 & 0.577 & 0.063 & 2.326 & 0.063 & 0.981 \\
\hline$P V-S P G$ & -0.573 & -0.652 & 6 & 0.577 & -1.784 & 0.480 & -0.945 & 0.446 \\
\hline$P V-L A$ & 0.714 & 0.895 & 6 & 0.577 & -0.236 & 2.027 & -0.232 & 0.966 \\
\hline$P V-F-T$ & 0.868 & 1.325 & 6 & 0.577 & 0.193 & 2.457 & 0.191 & 0.985 \\
\hline$P V-19 \%$ & 0.082 & 0.082 & 6 & 0.577 & -1.049 & 1.214 & -0.782 & 0.838 \\
\hline PV - META\% & 0.830 & 1.188 & 6 & 0.577 & 0.057 & 2.320 & 0.056 & 0.981 \\
\hline$P V-L S \%$ & -0.329 & -0.342 & 6 & 0.577 & -1.473 & 0.790 & -0.900 & 0.658 \\
\hline PV-DOL \% & -0.494 & -0.541 & 6 & 0.577 & -1.673 & 0.590 & -0.932 & 0.530 \\
\hline PV-OS\% & 0.228 & 0.232 & 6 & 0.577 & -0.900 & 1.364 & -0.716 & 0.877 \\
\hline PV - CRUSH\% & 0.804 & 1.110 & 6 & 0.577 & -0.022 & 2.241 & -0.022 & 0.978 \\
\hline$W 1-A B$ & 0.766 & 1.011 & 6 & 0.577 & -0.121 & 2.142 & -0.120 & 0.973 \\
\hline WI-SPG & -0.162 & -0.163 & 6 & 0.577 & -1.295 & 0.968 & -0.860 & 0.748 \\
\hline WI - LA & 0.351 & 0.367 & 6 & 0.577 & -0.765 & 1.498 & $-0,644$ & 0.905 \\
\hline WI - F-T & 0.727 & 0.922 & 6 & 0.577 & -0.209 & 2.054 & -0.206 & 0.968 \\
\hline$W|-| G \%$ & -0.325 & -0.337 & 6 & 0.577 & -1.469 & 0.794 & -0.899 & 0.661 \\
\hline WI-META\% & 0.183 & 0.185 & 6 & 0.577 & -0.947 & 1.317 & -0.738 & 0.866 \\
\hline$W 1-L S \%$ & 0.183 & 0.185 & 6 & 0.577 & -0.947 & 1.317 & -0.738 & 0.866 \\
\hline WI-DOL \% & 0.336 & 0.350 & 6 & 0.577 & -0.782 & 1.481 & -0.654 & 0.902 \\
\hline WI - OS\% & -0.197 & -0.200 & 6 & 0.577 & -1.331 & 0.932 & -0.870 & 0.732 \\
\hline WI - CRUSH\% & 0.781 & 1.048 & 6 & 0.577 & -0.084 & 2.180 & -0.083 & 0.975 \\
\hline
\end{tabular}


Appendix 2. Correlation Analysis

A. Limestone

The SAS System

11:42 Monday, July 17, 2000

Correlation Analysis

12

'VAR' Variables:

IFV

PV
P 200

WI

$\mathrm{AB}$

SPG

LA

SUL

MG

\title{
Simple statistics
}

$\begin{array}{lr}\text { Variable } & \mathbf{N} \\ \text { IFV } & 21 \\ \text { PV } & 21 \\ \text { WI } & 21 \\ \text { AB } & 20 \\ \text { SPG } & 20 \\ \text { LA } & 19 \\ \text { SUL } & 12 \\ \text { MG } & 21 \\ \text { T_ACID } & 21 \\ \text { P_200 } & 21 \\ \text { M_200 } & 21 \\ \text { RATIO } & 21\end{array}$

Mean
43.063333
24.767143
18.296190
1.495500
2.628950
28.191579
12.945000
2.911905
5.066190
1.306190
3.760000
0.402857

\begin{abstract}
Std Dev
2.659395

2.291369

2. 896157

0.525029

0.039451

4. 755024

7. 390808

3.063246

2. 677065

1. 247431

2. 068719

0.436362
\end{abstract}

Sum

904.330000

520.110000

384.220000

29.910000

52.579000

535.640000

155.340000

61.150000

106.390000

27.430000

78.960000

The SAS System

8. 460000

Minimum
38.600000
20.870000
10.460000
0.780000
2.517000
21.370000
3.010000
0.500000
1.410000
0.120000
1.270000
0.050000

Maximum

48.870000

29.240000

22.140000

2. 470000

2.698000

38.170000

27.460000

10.000000

12.720000

4. 830000

10.320000

1. 720000

Correlation Analysis

Pearson Correlation Coefficients / Prob $>|R|$ under Ho: Rho=0 / Number of , Observations

IFV

PV

$$
\begin{gathered}
1.00000 \\
0.0 \\
21
\end{gathered}
$$

PV

$$
0.32288
$$

21

WI

$$
\begin{array}{r}
0.66280 \\
0.0011
\end{array}
$$

$A B$

21

$$
\begin{array}{r}
0.10318 \\
0.6651
\end{array}
$$

20

$$
\begin{array}{r}
0.32288 \\
0.1534 \\
21 \\
1.00000 \\
0.0 \\
21 \\
0.49469 \\
0.0226 \\
21 \\
0.04740 \\
0.8427 \\
20
\end{array}
$$

WI

$$
\begin{array}{r}
0.66280 \\
0.0011 \\
21 \\
-0.49469 \\
0.0226 \\
21 \\
1.00000 \\
0.0 \quad \\
21 \\
0.05648 \\
0.8130 \\
20
\end{array}
$$

AB

$$
\begin{array}{r}
0.10318 \\
0.6651 \\
20 \\
0.04740 \\
0.8427 \\
20 \\
0.05648 \\
0.8130 \\
20 \\
1.00000 \\
0.0 \quad \\
20
\end{array}
$$

SPG

LA

$$
\begin{array}{r}
-0.20263 \\
0.3916 \\
20 \\
-0.07250 \\
0.7613 \\
20 \\
-0.12740 \\
0.5925 \\
20 \\
-0.75713 \\
0.0001 \\
20
\end{array}
$$$$
\begin{array}{r}
0.20225 \\
0.4063 \\
19 \\
-0.21025 \\
0.3876 \\
19 \\
0.35913 \\
0.1310 \\
19 \\
0.10063 \\
0.6819 \\
19
\end{array}
$$ 


\begin{tabular}{|c|c|c|c|c|c|c|}
\hline SPG & $\begin{array}{r}-0.20263 \\
0.3916\end{array}$ & $\begin{array}{r}-0.07250 \\
0.7613\end{array}$ & $\begin{array}{r}-0.12740 \\
0.5925\end{array}$ & $\begin{array}{r}-0.75713 \\
0.0001\end{array}$ & $\begin{array}{l}1.00000 \\
0.0\end{array}$ & $\begin{array}{r}-0.36788 \\
0.1212\end{array}$ \\
\hline & 20 & 20 & 20 & 20 & 20 & 19 \\
\hline \multirow[t]{3}{*}{ LA } & 0.20225 & -0.21025 & 0.35913 & 0.10063 & -0.36788 & 1.00000 \\
\hline & 0.4063 & 0.3876 & 0.1310 & 0.6819 & 0.1212 & 0.0 \\
\hline & 19 & 19 & 19 & 19 & 19 & 19 \\
\hline \multirow[t]{3}{*}{ SUL } & -0.58439 & 0.28632 & -0.65280 & -0.13827 & 0.19899 & -0.39756 \\
\hline & 0.0460 & 0.3669 & 0.0214 & 0.6683 & 0.5353 & 0.2260 \\
\hline & 12 & 12 & 12 & 12 & 12 & 11 \\
\hline \multirow[t]{3}{*}{ MG } & 0.05871 & 0.20545 & -0.10864 & 0.40689 & 0.05525 & -0.41644 \\
\hline & 0.8004 & 0.3716 & 0.6392 & 0.0750 & 0.8170 & 0.0761 \\
\hline & 21 & 21 & 21 & 20 & 20 & 19 \\
\hline \multirow{3}{*}{ T_ACID } & -0.08972 & 0.70343 & -0.63892 & 0.00952 & 0.11193 & -0.33871 \\
\hline & 0.6990 & 0.0004 & 0.0018 & 0.9682 & 0.6385 & 0.1560 \\
\hline & 21 & 21 & 21 & 20 & 20 & 19 \\
\hline \multirow[t]{3}{*}{ P_200 } & 0.05221 & 0.48816 & -0.33827 & -0.05069 & -0.11354 & -0.34775 \\
\hline & 0.8222 & 0.0248 & 0.1336 & 0.8319 & 0.6336 & 0.1446 \\
\hline & 21 & 21 & 21 & 20 & 20 & 19 \\
\hline \multirow[t]{7}{*}{ M_200 } & -0.14758 & 0.61593 & -0.62283 & 0.04289 & 0.21331 & -0.23565 \\
\hline & 0.5232 & 0.0030 & 0.0026 & 0.8575 & 0.3665 & 0.3314 \\
\hline & 21 & 21 & 21 & 20 & 20 & 19 \\
\hline & & & The SAS System & $11: 42$ & Monday, July 17 , & 2000 \\
\hline & & & Correlation Analysis & & & \\
\hline & Correlation & Coefficients & / Prob > $|R|$ under Ho & $D:$ Rho $=0$ / Num & mber of Observatic & ons \\
\hline & IFV & PV & WI & $\mathrm{AB}$ & SPG & LA \\
\hline \multirow[t]{6}{*}{ RATIO } & -0.11676 & 0.14690 & -0.22344 & 0.00236 & -0.22235 & -0.37292 \\
\hline & 0.6142 & 0.5252 & 0.3302 & 0.9921 & 0.3461 & 0.1158 \\
\hline & 21 & 21 & 21 & 20 & 20 & 19 \\
\hline & & & $\begin{array}{l}\text { The SAS System } \\
\text { Correlation Analysis }\end{array}$ & $11: 42$ & Monday, July 17 & 2000 \\
\hline & Correlation & Coefficients & $/$ Prob $>|R|$ under Ho: & $\mathrm{O}: \mathrm{Rho}=0 / \mathrm{N}$ & mber of Observatic & ons \\
\hline & SUL & MG & $T_{\text {__ACID }}$ & P_200 & M_200 & RATIO \\
\hline \multirow[t]{2}{*}{ IFV } & $\begin{array}{r}-0.58439 \\
0.0460\end{array}$ & $\begin{array}{r}0.05871 \\
0.8004\end{array}$ & $\begin{array}{r}-0.08972 \\
0.6990\end{array}$ & $\begin{array}{r}0.05221 \\
0.8222\end{array}$ & $\begin{array}{r}-0.14758 \\
0.5232\end{array}$ & $\begin{array}{r}-0.11676 \\
0.6142\end{array}$ \\
\hline & 12 & 21 & 21. & 21 & 21 & 21 \\
\hline \multirow[t]{2}{*}{ PV } & 0.28632 & 0.20545 & 0.70343 & 0.48816 & 0.61593 & 0.14690 \\
\hline & 0.3669 & 0.3716 & 0.0004 & 0.0248 & 0.0030 & 0.5252 \\
\hline
\end{tabular}




\begin{tabular}{|c|c|c|c|c|c|c|}
\hline & 12 & 21 & 21 & 21 & 21 & 21 \\
\hline \multirow[t]{3}{*}{ WI } & -0.65280 & -0.10864 & -0.63892 & -0.33827 & -0.62283 & -0.22344 \\
\hline & 0.0214 & 0.6392 & 0.0018 & 0.1336 & 0.0 .026 & 0.3302 \\
\hline & 12 & 21 & 21 & 21 & 21 & 21 \\
\hline \multirow[t]{3}{*}{$\mathrm{AB}$} & -0.13827 & 0.40689 & 0.00952 & -0.05069 & 0.04289 & 0.00236 \\
\hline & 0.6683 & 0.0750 & 0.9682 & 0.8319 & 0.8575 & 0.9921 \\
\hline & 12 & 20 & 20 & 20 & 20 & 20 \\
\hline \multirow[t]{3}{*}{ SPG } & 0.19899 & 0.05525 & 0.11193 & -0.11354 & 0.21331 & -0.22235 \\
\hline & 0.5353 & 0.8170 & 0.6385 & 0.6336 & 0.3665 & 0.3461 \\
\hline & 12 & 20 & 20 & 20 & 20 & 20 \\
\hline \multirow[t]{3}{*}{ LA } & -0.39756 & -0.41644 & -0.33871 & -0.34775 & -0.23565 & -0.37292 \\
\hline & 0.2260 & 0.0761 & 0.1560 & 0.1446 & 0.3314 & 0.1158 \\
\hline & 11 & 19 & 19 & 19 & 19 & 19 \\
\hline \multirow[t]{3}{*}{ SUL } & 1.00000 & 0.12455 & 0.71913 & 0.44226 & 0.43973 & 0.32463 \\
\hline & 0.0 & 0.6997 & 0.0084 & 0.1500 & 0.1526 & 0.3032 \\
\hline & 12 & 12 & 12 & 12 & 12 & 12 \\
\hline \multirow[t]{3}{*}{ MG } & 0.12455 & 1.00000 & 0.32261 & 0.07030 & 0.37509 & -0.01538 \\
\hline & 0.6997 & 0.0 & 0.1538 & 0.7620 & 0.0938 & 0.9472 \\
\hline & 12 & 21 & 21 & 21 & 21 & 21 \\
\hline \multirow[t]{3}{*}{ T_ACID } & 0.71913 & 0.32261 & 1.00000 & 0.66525 & 0.89292 & 0.18020 \\
\hline & 0.0084 & 0.1538 & 0.0 & 0.0010 & 0.0001 & 0.4344 \\
\hline & 12 & 21 & 21 & 21 & 21 & 21 \\
\hline \multirow{3}{*}{ P_200 } & 0.44226 & 0.07030 & 0.66525 & 1.00000 & 0.25789 & 0.78597 \\
\hline & 0.1500 & 0.7620 & 0.0010 & -0.0 & 0.2591 & 0.0001 \\
\hline & 12 & 21 & 21 & 21 & 21 & 21 \\
\hline \multirow[t]{3}{*}{ M_200 } & 0.43973 & 0.37509 & 0.89292 & 0.25789 & 1.00000 & -0.24075 \\
\hline & 0.1526 & 0.0938 & 0.0001 & 0.2591 & 0.0 & 0.2931 \\
\hline & 12 & 21 & 21 & 21 & 21 & 21 \\
\hline
\end{tabular}

The SAS System

Correlation Analysis

Pearson Correlation Coefficients / Prob $>|R|$ under Ho: Rho=0 / Number of Observations

SUL MG

$\begin{array}{rrrr}\text { T_ACID } & \text { P_200 } & \text { M_200 } & \text { RATIO } \\ 0.18020 & 0.78597 & -0.24075 & 1.00000 \\ 0.4344 & 0.0001 & 0.2931 & 0.0 \\ 21 & 21 & 21 & 21\end{array}$

$\begin{array}{rr}0.32463 & -0.01538 \\ 0.3032 & 0.9472 \\ 12 & 21\end{array}$

21

MG 
Correlation Analysis

12 'VAR' Variables: $\begin{array}{lllllll}\text { IFV } & \text { PV } & \text { WI } & \text { AB } & \text { SPG } & \text { LA } & \text { SUL } \\ \text { T_ACID } & \text { P_200 } & \text { M_200 } & \text { RATIO } & & \text { MG }\end{array}$

Simple statistics

$\begin{array}{ll}\text { Variable } & \text { N } \\ \text { IFV } & 20 \\ \text { PV } & 20 \\ \text { WI } & 20 \\ \text { AB } & 19 \\ \text { SPG } & 19 \\ \text { LA } & 19 \\ \text { SUL } & 18 \\ \text { MG } & 17 \\ \text { T_ACID } & 20 \\ \text { P_200 } & 20 \\ \text { M_200 } & 20 \\ \text { RATIO } & 20\end{array}$

Mean
43.550000
28.495000
15.055000
2.406316
2.603316
28.899474
4.666111
12.070588
3.816500
1.583000
2.233500
0.785000

\begin{abstract}
Std Dev
\end{abstract}

\section{321637}

3. 140311

1.748225

1. 289350

0.080683

3. 317582

3. 642939

0.894961

2.957099

1.534666

1. 812452

0.733983

The SAS System

Correlation Analysis

$\begin{array}{rrr}\text { Sum } & \text { Minimum } & \text { Maximum } \\ 871.000000 & 40.000000 & 47.600000 \\ 569.900000 & 23.600000 & 35.300000 \\ 301.100000 & 10.800000 & 18.300000 \\ 45.720000 & 0.790000 & 6.250000 \\ 49.463000 & 2.390000 & 2.732000 \\ 549.090000 & 22.470000 & 36.980000 \\ 83.990000 & 0.310000 & 13.180000 \\ 205.200000 & 10.100000 & 13.100000 \\ 76.330000 & 0.080000 & 9.820000 \\ 31.660000 & 0.020000 & 4.450000 \\ 44.670000 & 0.060000 & 6.280000 \\ 15.700000 & 0.030000 & 2.560000\end{array}$

MG

$11: 47$ Monday, July 17, 2000

Pearson Correlation Coefficients / Prob $>|R|$ under Ho: Rho=0 / Number of observations

IFV

$$
\begin{aligned}
& 1.00000 \\
& 0.0
\end{aligned}
$$

$\mathrm{PV}$

WI

AB

$\stackrel{0}{*}$
PV
0.83636
0.0001
1.00000
0.0
-0.68560
0.0008
20
0.76523
0.0001
19

WI

$$
\begin{array}{r}
-0.17435 \\
0.4622 \\
20 \\
-0.68560 \\
0.0008 \\
20 \\
1.00000 \\
0.0 \quad 20 \\
-0.53805 \\
0.0175 \\
19 \\
0.46240
\end{array}
$$

AB

$$
\begin{array}{r}
0.65025 \\
0.0026 \\
19 \\
0.76523 \\
0.0001 \\
19 \\
-0.53805 \\
0.0175 \\
19 \\
1.00000 \\
0.0 \quad \\
-0.96817
\end{array}
$$

SPG

$$
\begin{array}{r}
-0.67087 \\
0.0017 \\
19 \\
-0.74493 \\
0.0003 \\
19 \\
0.46240 \\
0.0462 \\
19 \\
-0.96817 \\
0.0001 \\
19 \\
1.00000
\end{array}
$$

$$
\begin{array}{r}
0.13232 \\
0.5892 \\
19 \\
0.10716 \\
0.6624 \\
19 \\
-0.00849 \\
0.9725 \\
19 \\
0.42739 \\
0.0680 \\
19 \\
-0.52870
\end{array}
$$


19

19

0.0080

-0.56742
0.0140

0.0646

0.0140
18

$\begin{array}{rr}-0.34540 & -0.65270 \\ 0.1745 & 0.0045\end{array}$

0.75604

0.0004

0.44825

0.41405

T_ACID

0.0695

0.0475

$-0.25533$

.25533
0.2773

0.20234

0.15757
0.5070

0.3923

$-0.15420$

0.5163

20

0.55958

0.0103

20

$-0.28601$

0.2215

$$
\begin{array}{r}
0.0001 \\
19 \\
0.42739 \\
0.0680 \\
19 \\
0.59233 \\
0.0096 \\
18 \\
-0.31927 \\
0.2281 \\
16 \\
0.00920 \\
0.9702 \\
19 \\
-0.21238 \\
0.3827 \\
19 \\
0.20439 \\
0.4013 \\
19
\end{array}
$$

0.0

0.0200

19
-0.52870
0.0200
19
-0.58818
0.0102
18
0.29564
0.2663
16
-0.05644
0.8185
19
0.19434
0.4253
19
-0.26904
0.2654
19

1.00000

0.0

19

-0.03362
0.8946

18

0.41488

0.1101

$-0.20460$

0.4008

$-0.20123$

0.2435

$-0.09973$

0.6846

The SAS System

$11: 47$ Monday, July 17, $2000 \quad 3$

Correlation Analysis
Pearson Correlation Coefficients / Prob $>|R|$ under Ho: Rho=0, Number of observations

IFV

$$
-0.42429
$$

0.0623
20

PV

WI

AB

. SPG

LA

RATIO

-0.24888
0.2900
20

$-0.11639$

0.6251

$-0.43279$

0.0642

0.48014

0.0375

$-0.30987$

$\begin{array}{rrr}19 & 19 & 19\end{array}$

The SAS System

Correlation Analysis

Pearson Correlation Coefficients / Prob $>|R|$ under Ho: Rho=0 / Number of Observations

SUL.

IFV

0.44441

0.0646

18

PV

$\stackrel{\wp}{\alpha}$
MG

-0.34540
0.1745
17
-0.65270
0.0045
17
0.75604

\section{T_ACID}

0.41405

0.0695

20
0.44825

0.0475

20

$-0.25533$
P_200

\begin{abstract}
0.15757
\end{abstract}
0.5070

20
0.20234

0.3923

20

$-0.15420$
M_200

0.54152

0.0137

0.55958

0.0103

20

$-0.28601$

RATIO

$$
\begin{array}{r}
-0.42429 \\
0.0623 \\
20 \\
-0.24888 \\
0.2900 \\
20 \\
-0.11639
\end{array}
$$

WI

$-0.56742$

.




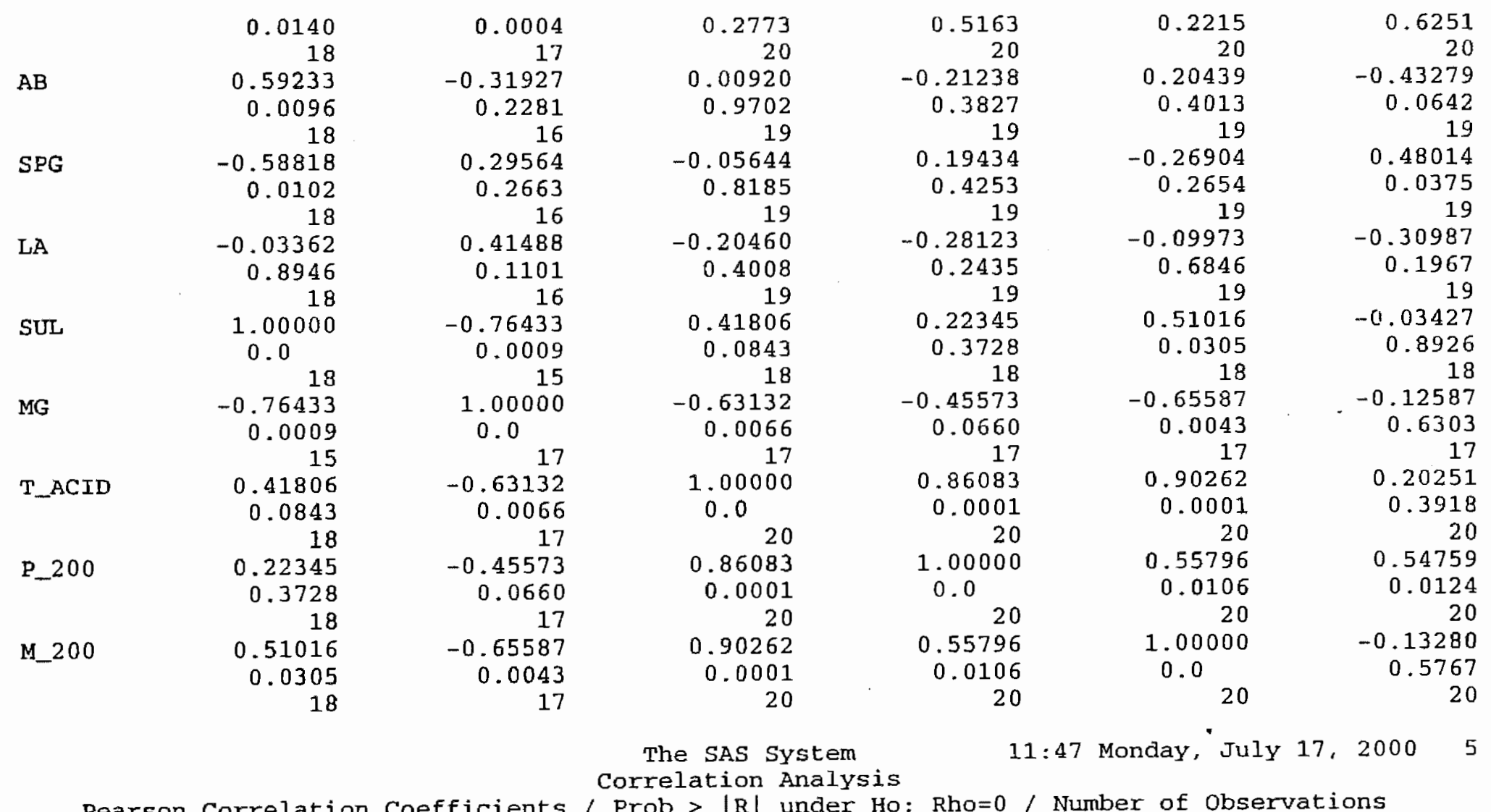

Pearson Correlation Coefficients / Prob > $|R|$ under Ho: Rho=0 / Number of observations

SUL

MG

T_ACID

P_200

M_200

RATIO

RATIO

$-0.03427-0.12587$

0.20251

0.54759 
C. Grave 1

13 'VAR' Variables: META
The SAS System

16:58 Saturday, July 15, 2000

1

Correlation Analysis

$\begin{array}{lll}\text { WI } & \text { AB } & \text { SPG } \\ \text { DOL } & \text { OS } & \text { CRUSH }\end{array}$

Simple Statistics

Variable
IFV
PV
WI
AB
SPG
LA
FH
IG
META
LS
DOL
OS
CRUSH

N
6
6
6
6
6
6
5
6
6
6
6
6
6

Std Dev
3.222215
1.490861
2.136040
0.749286
0.058722
2.370660
1.896800
3.071292
5.663097
5.225578
3.641359
1.805084
5.594475

Sum

233.000000

145.000000

88.000000

10.770000

15.651000

152.300000

29.750000

179.000000

52.600000

94.000000

106.400000

168.000000

367.000000
LA

FH

IG

The SAS System

$16: 58$ Saturday, JuIy 15, 20002

Correlation Analysis

Pearson Correlation Coefficients / Prob $>|R|$ under Ho: Rho $=0$ / Number of Observations

IFV

PV
WI

0.92424
0.0084
6
0.56481
0.2429
6
1.00000
$0.0 \quad 6$
0.76638
0.0755

$\mathrm{AB}$
0.89316
0.0165
0.83235
0.0398
0.76638
0.0755
1.00000
0.0

0.2429

0.83235

0.0398

6
SPG

$$
\begin{array}{r}
-0.37249 \\
0.4671 \\
6 \\
-0.57341 \\
0.2342 \\
6 \\
-0.16168 \\
0.7596 \\
6 \\
-0.47803 \\
0.3376
\end{array}
$$

Maximum

$\begin{array}{rr}35.300000 & 44.100000 \\ 22.600000 & 26.300000 \\ 12.100000 & 17.800000 \\ 1.210000 & 3.210000 \\ 2.509000 & 2.676000 \\ 22.640000 & 28.000000 \\ 4.490000 & 9.180000 \\ 9.000000 & 49.200000 \\ 3.600000 & 18.700000 \\ 6.200000 & 20.800000 \\ 0.400000 & 40.400000 \\ 16.000000 & 46.900000 \\ 10.000000 & 99.000000\end{array}$

LA

FH

0.56327
0.2445
6
0.71429
0.1108
6
0.35114
0.4949
6
0.74468
0.0895
6

0.84567

0.0711

0.86769

0.0566

0.72715

0.1639

0.0156 


\begin{tabular}{|c|c|c|c|c|c|c|c|}
\hline SPG & $\begin{array}{r}-0.37249 \\
0.4671\end{array}$ & $\begin{array}{r}-0.57341 \\
0.2342\end{array}$ & $\begin{array}{r}-0.16168 \\
0.7596\end{array}$ & $\begin{array}{r}-0.47803 \\
0.3376\end{array}$ & $\begin{array}{c}1.00000 \\
0.0\end{array}$ & $\begin{array}{r}-0.89321 \\
0.0165\end{array}$ & $\begin{array}{r}-0.36448 \\
0.5464\end{array}$ \\
\hline & 6 & 6 & 6 & 6 & 6 & 6 & 5 \\
\hline \multirow[t]{3}{*}{$\mathrm{LA}$} & 0.56327 & 0.71429 & 0.35114 & 0.74468 & -0.89321 & 1.00000 & 0.58090 \\
\hline & 0.2445 & 0.1108 & 0.4949 & 0.0895 & 0.0165 & 0.0 & 0.3044 \\
\hline & 6 & 6 & 6 & 6 & 6 & 6 & \\
\hline \multirow[t]{3}{*}{$\mathrm{FH}$} & 0.84567 & 0.86769 & 0.72715 & 0.94441 & -0.36448 & 0.58090 & 1.00000 \\
\hline & 0.0711 & 0.0566 & 0.1639 & 0.0156 & 0.5464 & 0.3044 & 0.0 \\
\hline & 5 & 5 & 5 & 5 & 5 & 5 & \\
\hline \multirow[t]{3}{*}{ IG } & -0.17777 & 0.08156 & -0.32509 & -0.20945 & -0.01175 & 0.11203 & -0.3421 \\
\hline & 0.7362 & 0.8779 & 0.5295 & 0.6904 & 0.9824 & 0.8327 & 0.573 \\
\hline & 6 & 6 & 6 & 6 & 6 & 6 & \\
\hline \multirow[t]{3}{*}{ META } & 0.50567 & 0.83013 & 0.18341 & 0.46638 & -0.76446 & 0.65743 & 0.6768 \\
\hline & 0.3061 & 0.0408 & 0.7280 & 0.3511 & 0.0767 & 0.1559 & 0.20 \\
\hline & 6 & 6 & 6 & 6 & 6 & 6 & \\
\hline \multirow[t]{3}{*}{ LS } & -0.03104 & -0.32877 & 0.18264 & 0.06569 & 0.48772 & -0.13925 & 0.1410 \\
\hline & 0.9535 & 0.5246 & 0.7291 & 0.9016 & 0.3264 & 0.7925 & 0.821 \\
\hline & 6 & 6 & 6 & 6 & 6 & 6 & . \\
\hline \multirow[t]{3}{*}{ DOL } & -0.00599 & -0.49449 & 0.33610 & -0.00440 & 0.49003 & -0.40093 & 0.145 \\
\hline & 0.9910 & 0.3187 & 0.5148 & 0.9934 & 0.3238 & 0.4308 & 0.81 \\
\hline & 6 & 6 & 6 & 6 & 6 & 6 & \\
\hline
\end{tabular}

The SAS System

$16: 58$ Saturday, July 15, 20003 Correlation Analysis

Pearson Correlation Coefficients / Prob $>|R|$ under Ho: Rho=0 / Number of observations

$\begin{array}{lllllll}\text { IFV } & \text { PV } & \text { WI } & \text { SB } & \text { LA } & \text { FH }\end{array}$

$\begin{array}{lrrrrrr}\text { OS } & 0.02508 & 0.22841 & -0.19725 & -0.01580 & -0.40241 & 0.08551 \\ & 0.9624 & 0.6633 & 0.7080 & 0.9763 & 0.4290 & 0.08337 \\ \text { CRUSH } & 6 & 6 & 6 & 6 & 0.8721 & 0.8940 \\ & 0.89014 & 0.80440 & 0.78135 & 0.71799 & -0.62133 & 0.67435 \\ & 0.0174 & 0.0536 & 0.0665 & 0.1081 & 0.1879 & 0.1418 \\ & 6 & 6 & 6 & 6 & 0.2927 \\ & & & 6 & 6 & 6\end{array}$

The SAS System

$16: 58$ Saturday, July $15,2000 \quad 4$

Correlation Analysis

Pearson Correlation Coefficients / Prob $>|R|$ under Ho: Rho=0 / Number of observations

IG

IFV
META

$$
-0.17777
$$

0.7362
LS

$\begin{array}{rr}0.50567 & -0.03104 \\ 0.3061 & 0.9535\end{array}$

DOL

$$
\begin{array}{r}
-0.00599 \\
0.9910
\end{array}
$$

OS

$-0.02508$
CRUSH
0.89014 0.0174 


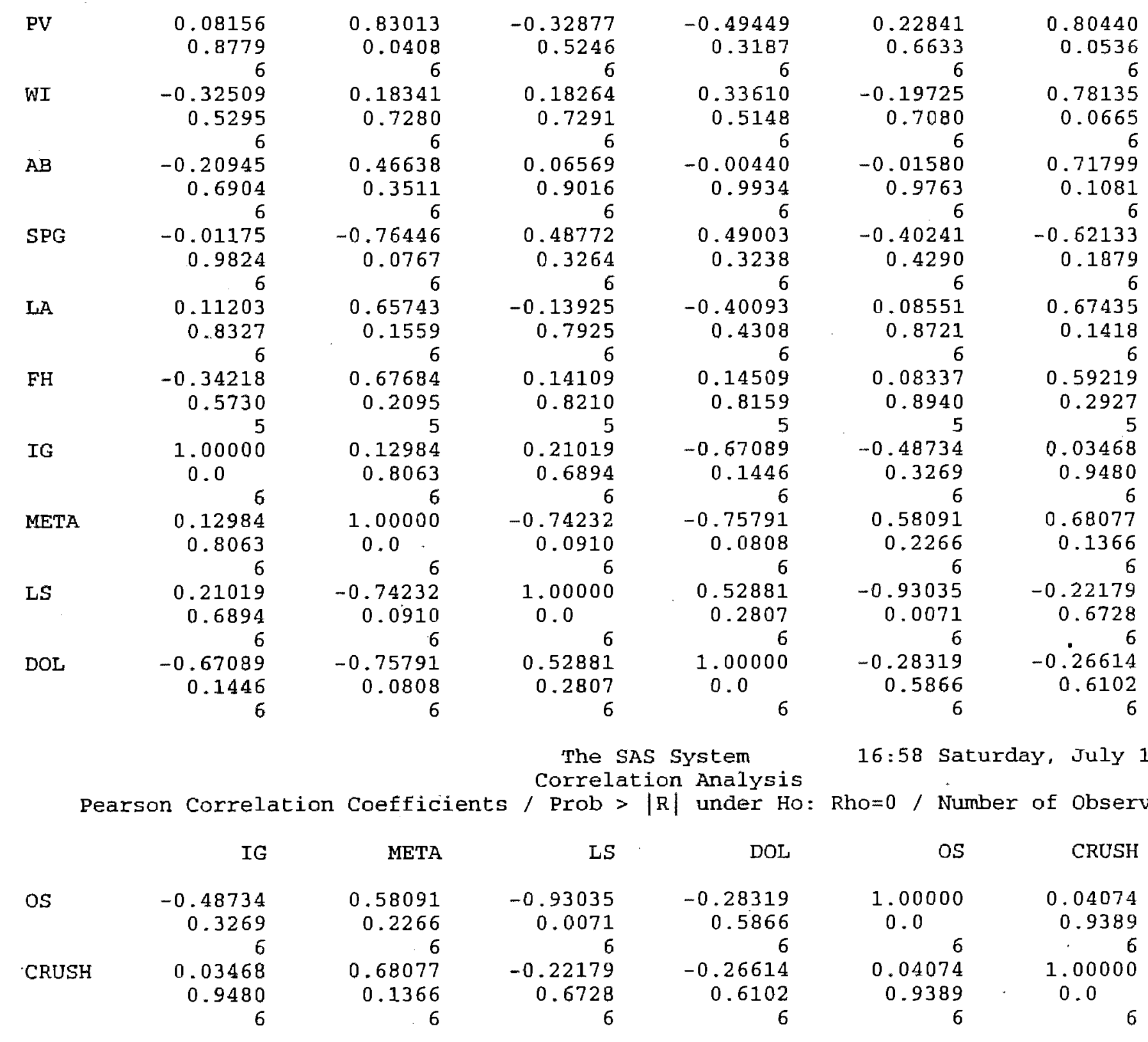


The CORR Procedure

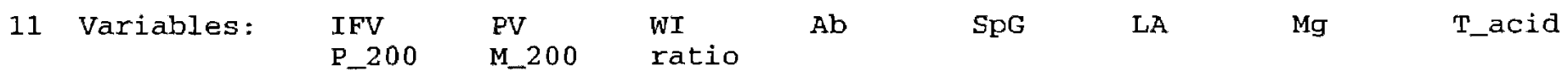

Simple statistics

$\begin{array}{ll}\text { Variable } & \mathrm{N} \\ \text { IFV } & 41 \\ \text { PV } & 41 \\ \text { WI } & 41 \\ \text { Ab } & 39 \\ \text { SpG } & 39 \\ \text { LA } & 38 \\ \text { Mg } & 38 \\ \text { T_acid } & 41 \\ \text { P_200 } & 41 \\ \text { M_200 } & 41 \\ \text { ratio } & 41\end{array}$

IFV

$\begin{array}{rr}\text { Mean } & \text { Std Dev } \\ 43.30073 & 2.48135 \\ 26.58561 & 3.29672 \\ 16.71512 & 2.88721 \\ 1.93923 & 1.06677 \\ 2.61646 & 0.06348 \\ 28.54553 & 4.05989 \\ 7.00395 & 5.17147 \\ 4.45659 & 2.85252 \\ 1.44122 & 1.38434 \\ 3.01537 & 2.07290 \\ 0.58927 & 0.62330\end{array}$

Sum
1775
1090
685.32000
75.63000
102.04200
1085
266.15000
182.72000
59.09000
123.63000
24.16000

Minimum

38.60000

20.87000

10.46000

0.78000

2.39000

21.37000

0.50000

0.08000

0.02000

0.06000

0.03000

Pearson Correlation Coefficients Prob $>|r|$ under HO: Rho=0 Number of Observations PV

WI

Ab

$$
0.53112
$$

0.0004

$$
\begin{array}{r}
0.25297 \\
0.1105 \\
41 \\
-0.68538 \\
<.0001
\end{array}
$$

1. 00000

41.

0.0004

WI

Ab

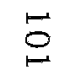

Spg
41

0.25297
0.1105

41

0.41339

0.0089

$$
\begin{array}{rr}
41 & 1.00000
\end{array}
$$

$-0.46565$

0.0028$$
<.0001
$$$$
41
$$

0.66386

$<.0001$

39

$$
1.00000
$$

41

$$
-0.39155
$$$$
0.0137
$$$$
39
$$

$-0.55598$

0.0 .002$$
0.22039
$$$$
0.1776
$$

$$
\begin{array}{r}
0.41339 \\
0.0089 \\
39 \\
0.66386 \\
<.0001 \\
39 \\
-0.39155 \\
0.0137 \\
39 \\
1.00000 \\
39 \\
-0.90864 \\
<.0001
\end{array}
$$

\section{Maximum}

48.87000

35.30000

22.14000

6.25000

2. 73200

38.17000

13.10000

12.72000

4.83000

10.32000

2. 56000

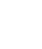


LA

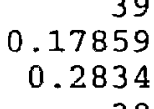

Mg

T_acid

p 200

M_200

ratio

IFV
0.00014
0.00014
39
0.15935
0.15935
0.3393

38
39
0.26977
0.1014

39
-0.41367

0.0098

38

1. 00000

38

The SAS System

11:01 Friday, May 25, 2001

5
IFV

Pearson Correlation Coefficients

$$
\text { Prob }>|r| \text { under } \mathrm{HO}: \text { Rho }=0
$$

Number of Observations

PV

WI

$\mathrm{Ab}$

$$
\begin{array}{r}
-0.47838 \\
0.0024
\end{array}
$$$$
0.4832
$$

0.49694
0.0015

38

0.31281

0.0465

$-0.25092$

0.1136

0.4412

41

0.11289

0.4822

0.31226

0.0469

41

0.22174

0.1635

41

0.5567

41

-0.23506
0.1390

41
41
-0.25954

0.1013

$-0.17196$

0.2823

41

0.0619

$$
\begin{array}{r}
0.41896 \\
0.0110 \\
36 \\
-0.09470 \\
0.5663 \\
39 \\
-0.09748 \\
0.5549 \\
39 \\
-0.06607 \\
0.6894 \\
39 \\
-0.14606 \\
0.3749 \\
39
\end{array}
$$

0.08068
0.6161

41
Pearson Correlation Coefficients Prob $>|r|$ under $\mathrm{HO}:$ Rho $=0$

Number of Observations

$\mathrm{Mg}$

$$
\text { T_acid }
$$

$$
\text { P_200 }
$$

$$
\text { M_200 }
$$

SpG

LA

$$
\begin{array}{r}
-0.16108 \\
0.3480 \\
36 \\
0.04607 \\
0.7806 \\
39 \\
0.07465 \\
0.6515 \\
39 \\
0.01405 \\
0.9324 \\
39 \\
0.22075 \\
0.1769 \\
39
\end{array}
$$$$
-0.05381
$$$$
\begin{array}{r}
-0.05381 \\
.0 .7588
\end{array}
$$$$
35
$$$$
-0.28739
$$$$
0.0802
$$$$
-0.29027
$$$$
0.0771
$$$$
-0.20493
$$$$
0.2171
$$

$-0.25449$

0.1231

$$
\begin{array}{rr}
0.11727 & 0.12364 \\
0.4832 & 0.4412 \\
. \quad 38 & 41 \\
0.49694 & 0.31281 \\
0.0015 & 0.0465 \\
38 & 41 \\
-0.47838 & -0.25092 \\
0.0024 & 0.1136
\end{array}
$$$$
0.11289
$$$$
0.4822
$$

0.09451

0.5567$$
0.31226
$$$$
0.0469
$$$$
0.22174
$$$$
0.1635
$$$$
-0.25954
$$$$
0.1013
$$

41

$-0.17196$

0.2823

41

$\begin{array}{rrr}13 & 0.2823 & 0.0619\end{array}$




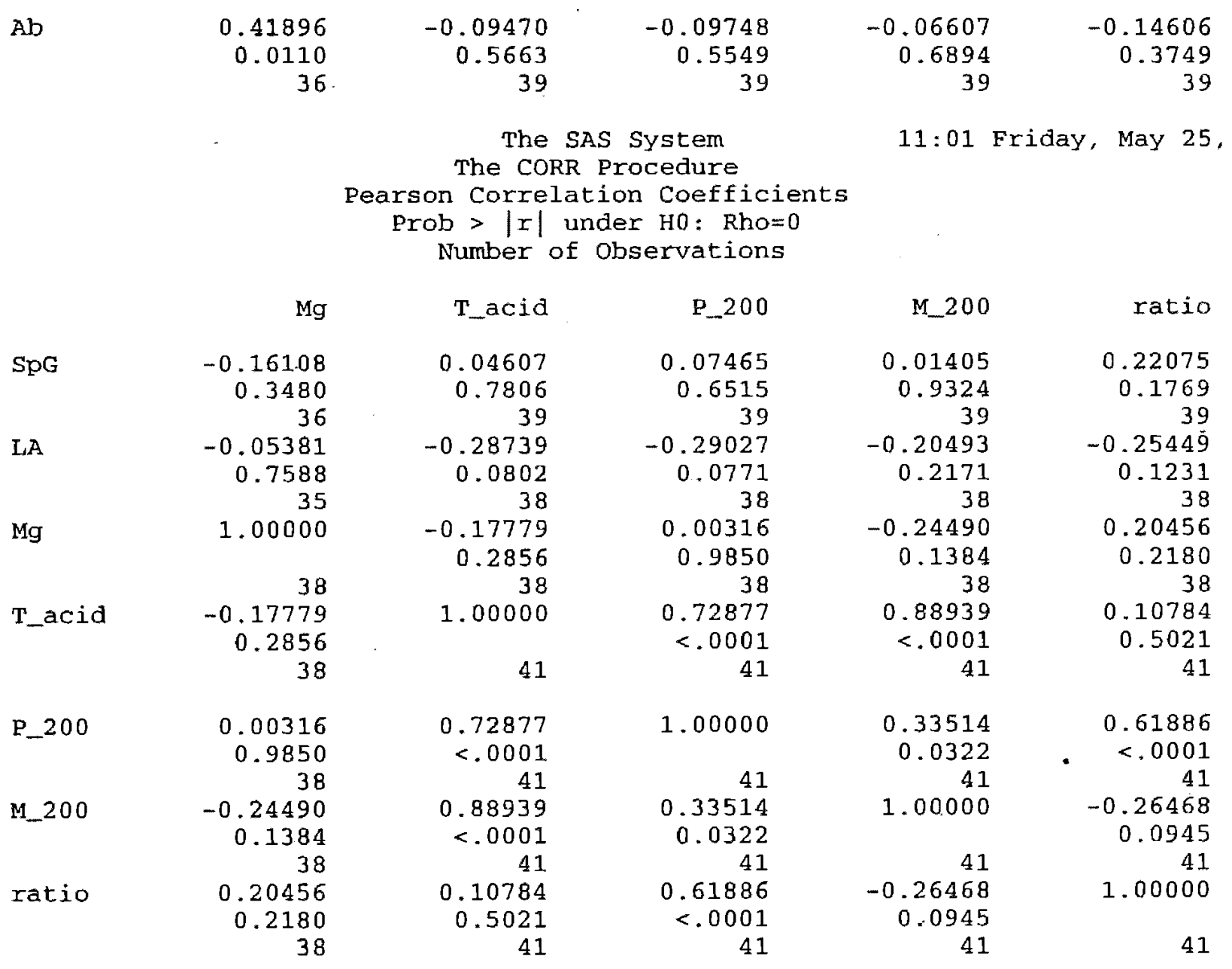


Appendix 3. Multiple Regression Analysis

A. Limestone

The SAS System

09:51 Friday, May 25, 2001

The REG Procedure

Model: MODELI

Dependent Variable: PV

Stepwise Selection: Step 1

Variable tacid Entered: $R$-Square $=0.4954$ and $C(p)=0.1066$

Analysis of Variance

\begin{tabular}{|c|c|c|c|c|c|c|}
\hline Source & DF & $\begin{array}{l}\text { Sum of } \\
\text { Squares }\end{array}$ & $\begin{array}{l}\text { Mean } \\
\text { Square }\end{array}$ & $F$ & Value & Pr $>F$ \\
\hline Model & 1 & 52.01760 & 52.01760 & & 17.67 & 0.0005 \\
\hline Error & 18 & 52.98750 & 2.94375 & & & \\
\hline Corrected Total & 19 & 105.00510 & & & & \\
\hline
\end{tabular}

$\begin{array}{lrrrrr} & \begin{array}{r}\text { Parameter } \\ \text { Estimate }\end{array} & \begin{array}{r}\text { Standard } \\ \text { Error }\end{array} & \text { Type II SS F Value } & \text { Pr }>\text { F } \\ \text { Intercept } & 21.70062 & 0.82472 & 2038.11814 & 692.35 & <.0901 \\ \text { tacid } & 0.60292 & 0.14343 & 52.01760 & 17.67 & 0.0005\end{array}$

Bounds on condition number: 1,1

All variables left in the model are significant at the 0.1500 level.

The SAS System

09:51 Friday, May 25, 200110

The REG Procedure

Model: MODEL1

Dependent Variable: PV

Stepwise Selection: Step 1

Variable tacid Entered: R-Square $=0.4954$ and $C(p)=0.1066$

Analysis of Variance 


$\begin{array}{lrrrrr} & & \text { Mum of } & \text { Mean } & \text { Square } & \text { F Value } \\ \text { Source } & \text { DF } & \text { Squares } & \text { Pr } \\ \text { Model } & 1 & 52.01760 & 52.01760 & 17.67 & 0.0005 \\ \text { Error } & 18 & 52.98750 & 2.94375 & \\ \text { Corrected Total } & 19 & 105.00510 & & \end{array}$

$\begin{array}{lrrrrr}\text { Variable } & \begin{array}{r}\text { Parameter } \\ \text { Estimate }\end{array} & \begin{array}{c}\text { Standard } \\ \text { Error }\end{array} & \text { Type II SS F Value Pr }>\text { F } \\ \text { Intercept } & 21.70062 & 0.82472 & 2038.11814 & 692.35 & <.0001 \\ \text { tacid } & 0.60292 & 0.14343 & 52.01760 & 17.67 & 0.0005\end{array}$

Bounds on condition number: 1,1

AII variables left in the model are significant at the 0.1500 level.

No other variable met the 0.1500 significance level for entry into the model.

Summary of stepwise Selection

\begin{tabular}{|c|c|c|c|c|c|c|c|c|c|}
\hline Step & $\begin{array}{l}\text { Variable } \\
\text { Entered }\end{array}$ & $\begin{array}{l}\text { Variable } \\
\text { Removed }\end{array}$ & $\begin{array}{l}\text { Number } \\
\text { Vars In }\end{array}$ & $\begin{array}{l}\text { Partial } \\
\text { R-Square }\end{array}$ & $\begin{array}{c}\text { Model } \\
\mathrm{R} \text {-Square }\end{array}$ & $c(p)$ & $F$ & Value & $\operatorname{Pr}>F$ \\
\hline 1 & tacid & & 1 & 0.4954 & 0.4954 & 0.106 & & 1.7 .67 & 0.0005 \\
\hline
\end{tabular}

\begin{tabular}{|c|c|c|c|c|c|c|c|c|c|c|c|}
\hline IFV & PV & WI & $a b$ & spg & $1 a$ & sul & $\mathrm{mg}$ & tacid & $\mathrm{p} 200$ & $\mathrm{~m} 200$ & ratio \\
\hline 38.60 & 28.14 & 10.46 & 2.170 & 2.591 & 28.500 & & 5.40 & 12.72 & 2.40 & 10.32 & 0.23 \\
\hline 40.20 & 24.72 & 15.48 & 1.780 & 2.586 & 27.000 & 22.25 & 0.70 & 5.76 & 3.64 & 2. 12 & 1.72 \\
\hline 44.38 & 22.69 & 21.69 & 2.000 & 2.604 & 21.370 & 7.98 & 9.50 & 4.09 & 2.04 & 2.05 & 1.00 \\
\hline 43.14 & 23.49 & 19.65 & 1.030 & 2.633 & 32.090 & 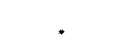 & 3.60 & 3.37 & 0.24 & 3.13 & 0.08 \\
\hline 39.48 & 21.67 & 17.81 & 0.930 & 2.652 & 28.600 & . & 2.20 & 4.96 & 1.53 & 3.43 & 0.45 \\
\hline 43.00 & 20.87 & 22.13 & 1.350 & 2.631 & 37.230 & 10.92 & 0.60 & 1.97 & 0.15 & 1.82 & 0.08 \\
\hline 41.13 & 25.50 & 15.63 & 1.260 & 2.624 & & 16.52 & 0.90 & 4.54 & 2.36 & 2.18 & 1.08 \\
\hline 41.76 & 24.97 & 16.79 & 1.150 & 2.653 & 26.490 & 27.46 & 2.50 & 6.00 & 0.70 & 5.30 & 0.13 \\
\hline 42.26 & 27.40 & 14.86 & 2.065 & 2.642 & 25.935 & 15.43 & 9.05 & 6.38 & 0.30 & 6.08 & 0.05 \\
\hline 45.30 & 25.39 & 19.91 & 2.330 & 2.621 & 23.030 & 19.47 & 10.00 & 6.17 & 1.80 & 4.37 & 0.41 \\
\hline 43.68 & 25.39 & 18.29 & 0.780 & 2.698 & 32.240 & 7.46 & 4.60 & 5.14 & 0.86 & 4.28 & 0.20 \\
\hline 46.69 & 27.51 & 19.18 & 1.005 & 2.670 & 25.730 & 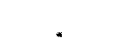 & 2.30 & 6.04 & 0.60 & 5.44 & 0.11 \\
\hline 48.87 & 29.24 & 19.63 & 1.050 & 2.639 & 27.720 & & 1.90 & 11.21 & 4.83 & 6.38 & 0.76 \\
\hline
\end{tabular}




$\begin{array}{llllllllllllll}14 & 44.10 & 25.00 & 19.10 & 1.530 & 2.626 & 28.490 & 8.06 & 1.60 & 4.13 & 1.43 & 2.70 & 0.53 \\ 15 & 43.21 & 27.12 & 16.09 & 0.880 & 2.638 & 22.400 & . & 1.10 & 4.41 & 1.86 & 2.55 & 0.73 \\ 16 & 41.02 & 24.72 & 16.30 & . & . & . & . & 1.10 & 4.59 & 1.16 & 3.43 & 0.34 \\ 17 & 47.85 & 25.73 & 22.12 & 2.470 & 2.517 & 38.170 & 3.01 & 0.50 & 1.41 & 0.14 & 1.27 & 0.11 \\ 18 & 44.69 & 22.55 & 22.14 & 1.970 & 2.592 & 34.760 & . & 0.70 & 2.28 & 0.12 & 2.16 & 0.06 \\ 19 & 42.37 & 23.95 & 18.42 & 1.320 & 2.634 & 24.790 & 11.30 & 0.70 & 4.01 & 0.64 & 3.37 & 0.19 \\ 20 & 40.10 & 22.05 & 18.05 & 1.150 & 2.689 & 24.390 & . & 1.20 & 3.61 & 0.47 & 3.14 & 0.15 \\ 21 & 42.50 & 22.01 & 20.49 & 1.690 & 2.639 & 26.705 & 5.38 & 1.00 & 3.60 & 0.16 & 3.44 & 0.05\end{array}$

Stepwise Procedure for Dependent Variable PV

The first 3 variables are forced into the model because of the INCIUDE= option.

Step 0 The First 3 Vars Entered R-square $=0.49883949 \quad \mathrm{C}(\mathrm{p})=4.00000000$

\begin{tabular}{|c|c|c|c|c|c|}
\hline & $D F$ & Sum of Squares & Mean Square & $F$ & Erob $>E$ \\
\hline Regression & 3 & 52.38068754 & 17.46022918 & 5.31 & 0.0099 \\
\hline Error & 16 & 52.62440746 & 3.28902547 & & \\
\hline Total & 19 & 105.00509500 & & & \\
\hline Variable & $\begin{array}{c}\text { Parameter. } \\
\text { Estimate }\end{array}$ & $\begin{array}{r}\text { Standard } \\
\text { Error }\end{array}$ & $\begin{array}{r}\text { Type II } \\
\text { Sum of Squares }\end{array}$ & $F$ & Prob>F \\
\hline INTERCEP & 21.33741392 & 1.51508421 & 652.34487988 & 198.34 & 0.0001 \\
\hline$A B$ & 0.27327327 & 0.87869865 & 0.31811314 & 0.10 & 0.7598 \\
\hline MG: & -0.03757113 & 0.15667370 & $\because 0.18914010$ & 0.06 & 0.8135 \\
\hline TACID & 0.61607810 & 0.16170862 & 47.73890224 & 14.51 & 0.0015 \\
\hline
\end{tabular}

Bounds on condition number: $\quad 1.370403, \quad 11.21282$

Il variables left in the model are required or significant at the 0.15001 level.

No other variable met the 0.0500 significance level for entry into the model. 
The REG Procedure

Model : MODEL1

Dependent Variable: PV

Stepwise Selection: Step 1

Variable ab Entered: $\mathrm{R}-$ Square $=0.6025$ and $\mathrm{C}(\mathrm{p})=9.5580$

Analysis of Variance

$\begin{array}{lrrrr} & & \text { Sum of } & \text { Mean } & \text { Pr } \\ \text { Source } & \text { DF } & \text { Squares } & \text { Square } & \text { F Vlue } \\ \text { Model } & 1 & 101.59776 & 101.59776 & 21.22 \\ \text { Error } & 14 & 67.03162 & 4.78797 & 0.0004 \\ \text { Corrected Total } & 15 & 168.62937 & & \end{array}$

$\begin{array}{lrrrrr} & \begin{array}{r}\text { Parameter } \\ \text { Estimate }\end{array} & \begin{array}{r}\text { Standard } \\ \text { Error }\end{array} & \text { Type II SS } & \text { F Value } & \text { Pr }>\text { F } \\ \text { Intercept } & 23.76289 & 1.12548 & 2134.40654 & 445.79 & <.0001 \\ \text { ab } & 1.87322 & 0.40665 & 101.59776 & 21.22 & 0.0004\end{array}$

Bounds on condition number: 1,1

Stepwise Selection: Step 2

Variable $\mathrm{mg}$ Entered: $\mathrm{R}-\mathrm{Square}=0.7467$ and $\mathrm{C}(\mathrm{p})=3.7385$

Analysis of Variance

\begin{tabular}{|c|c|c|c|c|c|}
\hline Source & $\mathrm{DF}$ & $\begin{array}{r}\text { Sum of } \\
\text { Squares }\end{array}$ & $\begin{array}{l}\text { Mean } \\
\text { Square }\end{array}$ & F Válue & $\operatorname{Pr}>\mathrm{F}$ \\
\hline Model & 2 & 125.91126 & 62.95563 & 19.16 & 0.0001 \\
\hline Error & 13 & 42.71812 & 3.28601 & & \\
\hline Corrected Total & 15 & 168.62937 & & & \\
\hline
\end{tabular}


The REG Procedure

Model: MODEL1

Dependent Variable: PV

Stepwise Selection: Step 2

$\begin{array}{lrrrrr} & \begin{array}{r}\text { Parametex } \\ \text { Estimate }\end{array} & \begin{array}{r}\text { Standard } \\ \text { Errox }\end{array} & \text { Type II SS } & \text { F Value } & \text { Pr }>\text { F } \\ \text { Intercept } & 46.03310 & 8.24011 & 102.55174 & 31.21 & <.0001 \\ \mathrm{ab} & 1.56450 & 0.35549 & 63.64479 & 19.37 & 0.0007 \\ \mathrm{mg} & -1.76512 & 0.64891 & 24.31350 & 7.40 & 0.0175\end{array}$

Bounds on condition number: $1.1135,4.454$

All variables left in the model are significant at the 0.1500 level.

No other variable met the 0.1500 significance level for entry into the model.

Summary of Stepwise selection

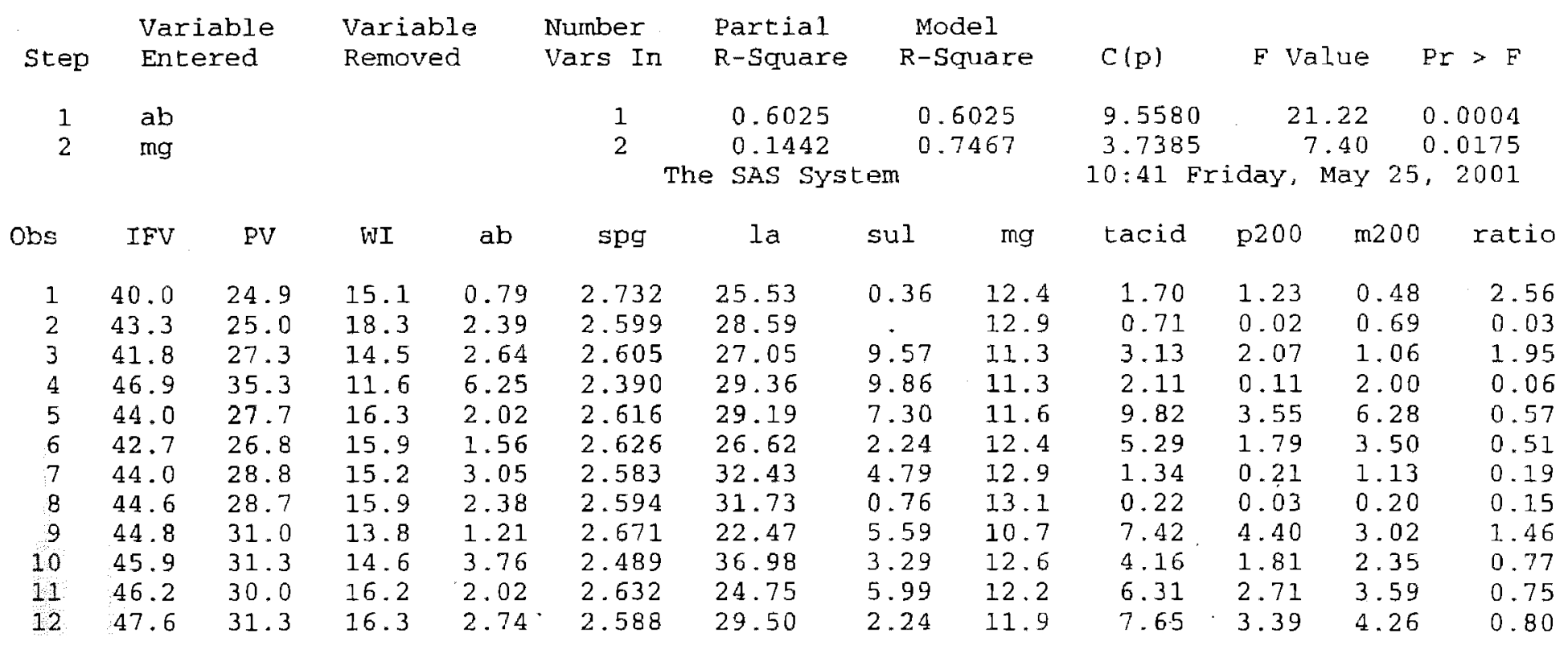




$\begin{array}{rrrrrrrrrrrrr}13 & 43.5 & 32.7 & 10.8 & . & . & . & .5 & 10.1 & 5.56 & 0.78 & 4.78 & 0.16 \\ 14 & 46.7 & 32.0 & 14.7 & 4.00 & 2.480 & 30.28 & 13.18 & 11.2 & 5.27 & 0.71 & 4.55 & 0.16 \\ 15 & 40.5 & 24.1 & 16.4 & 1.03 & 2.669 & 29.76 & 2.56 & 12.8 & 0.50 & 0.27 & 0.22 & 1.23 \\ 16 & 40.1 & 23.6 & 16.5 & 1.86 & 2.614 & 32.62 & 0.55 & 12.9 & 0.08 & 0.02 & 0.06 & 0.33 \\ 17 & 41.3 & 24.9 & 16.4 & 1.00 & 2.718 & 25.69 & 0.31 & 12.9 & 0.35 & 0.03 & 0.32 & 0.09 \\ 18 & 43.6 & 28.4 & 15.2 & 2.48 & 2.619 & 27.25 & 3.62 & . & 2.15 & 0.94 & 1.21 & 0.78 \\ 19 & 41.6 & 28.0 & 13.6 & 1.59 & 2.648 & 30.75 & 6.45 & . & 6.66 & 4.45 & 2.21 & 2.01 \\ 20 & 41.9 & 28.1 & 13.8 & 2.95 & 2.590 & 28.54 & 5.33 & . & 5.90 & 3.14 & 2.76 & 1.14\end{array}$

Stepwise Frocedure for Dependent Variable PV

The Eirst 3 variables are forced into the model because of the INCLUDE= option.

Step 0 The First 3 Vars Entered R-square $=0.77873139 . \quad C(p)=4.00000000$

\begin{tabular}{|c|c|c|c|c|c|}
\hline & $\mathrm{DF}$ & Sum of Squares & Mean Square & $\mathrm{F}$ & Prob $>F$ \\
\hline Regression & 3 & 131.31698690 & 43.77232897 & 14.08 & 0.0003 \\
\hline Error & 12 & 37.31238810 & $3.10 \div 36568$ & & \\
\hline Total & 15 & 168.62937500 & & & \\
\hline & Parameter & Standard & Type II & & \\
\hline Variable & Estimate & Error & Sum of Squares & $\mathrm{F}$ & Prob $>F$ \\
\hline INTERCEP & 38.02318391 & 10.05750671 & 44.44143753 & 14.29 & 0.0026 \\
\hline$A B$ & 1.55678486 & 0.34585261 & 63.00092053 & 20.26 & 0.0007 \\
\hline MG & -1.17495766 & 0.77381513 & 7.16872294 & 2.31 & 0.1548 \\
\hline M200 & 0.39500808 & 0.29958135 & 5.40572821 . & 1.74 & 0.2119 \\
\hline
\end{tabular}

Bounds on condition number: $1.673367, \quad 13.06769$

All variables left in the model are required or significant at the 0.1500 level.

No other :he 0.0500 significance level for entry into the model. 
The REG Procedure

Model: MODEL1

Dependent Variable: PV

Stepwise Selection: Step 1

Variable $a b$ Entered: $R-$ Square $=0.4427$ and $C(p)=23.2884$

Analysis of Variance

\begin{tabular}{|c|c|c|c|c|c|}
\hline Source & $\mathrm{DF}$ & $\begin{array}{r}\text { Sum of } \\
\text { Squares }\end{array}$ & $\begin{array}{r}\text { Mean } \\
\text { Square }\end{array}$ & F Value & $\operatorname{Pr}>F$ \\
\hline Model & 1 & 170.02372 & 170.02372 & 27.01 & $<.0001$ \\
\hline Error & 34 & 214.01375 & 6.29452 & & \\
\hline Corrected Total & 35 & 384.03747 & & & \\
\hline
\end{tabular}

$\begin{array}{lrrrrr} & \begin{array}{r}\text { Parameter } \\ \text { Estimate }\end{array} & \begin{array}{r}\text { Standard } \\ \text { Error }\end{array} & \text { Type II SS F Value } & \text { Pr }>\text { F } \\ \text { Intercept } & 22.49064 & 0.84984 & 4408.51711 & 700.37 & <.0001 \\ \text { ab } & 2.01759 & 0.38820 & 170.02372 & 27.01<0001\end{array}$

Bounds on condition number: 1,1

Stepwise Selection: Step 2

Variable tacid Entered: $R$-Square $=0.5875$ and $C(p)=10.9254$

Analysis of Variance

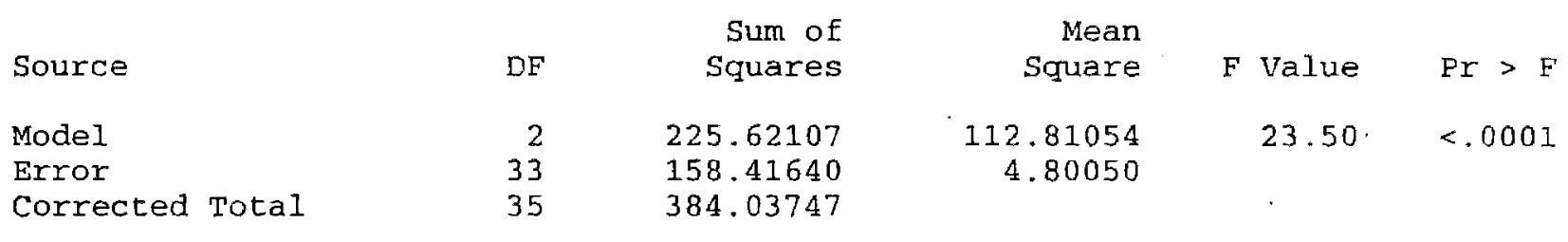


The REG Procedure

Model: MODEL1

Dependent Variable: PV

Stepwise Selection: Step 2

$\begin{array}{lrrrrr}\text { Variable } & \begin{array}{r}\text { Parameter } \\ \text { Estimate }\end{array} & \begin{array}{r}\text { Standard } \\ \text { Error }\end{array} & \text { TYpe II SS } & \text { F Value } & \text { Pr }>\text { F } \\ \text { Intercept } & 20.42284 & 0.95916 & 2176.36962 & 453.36 & <.0001 \\ \text { ab } & 2.12667 & 0.34053 & 187.23176 & 39.00 & <.0001 \\ \text { tacid } & 0.42415 & 0.12463 & 55.59735 & 11.58 & 0.0018\end{array}$

Bounds on condition number: $1.0089,4.0358$

Variable mg2 Entered: $R$-Square $=0.6831$ and $C(p)=3.4406$

Analysis of Variance

\begin{tabular}{|c|c|c|c|c|c|c|c|}
\hline Source & $D F$ & $\begin{array}{l}\text { Sum of } \\
\text { Squares }\end{array}$ & & $\begin{array}{r}\text { Me } \\
\text { Squa }\end{array}$ & $\begin{array}{l}\text { an } \\
\text { re }\end{array}$ & Value & $\operatorname{Pr}>F$ \\
\hline Model & 3 & 262.33526 & & 87.445 & & 22.99 & $<.0001$ \\
\hline Error & 32 & 121.70222 & & 3.803 & & & \\
\hline Corrected Total & 35 & 384.03747 & & & & & \\
\hline Variable & $\begin{array}{l}\text { Parameter } \\
\text { Estimate }\end{array}$ & $\begin{array}{r}\text { Standard } \\
\text { Error }\end{array}$ & Type & II SS & F Value & $\operatorname{Pr}>$ & \\
\hline $\begin{array}{l}\text { Intercept } \\
\mathrm{ab} \\
\text { mg2 } \\
\text { tacid }\end{array}$ & $\begin{array}{r}19.54640 \\
1.71285 \\
0.01636 \\
0.51888\end{array}$ & $\begin{array}{l}0.89913 \\
0.33107 \\
0.00526 \\
0.11505\end{array}$ & $\begin{array}{r}1797 \\
101 \\
36 \\
77\end{array}$ & $\begin{array}{l}.35912 \\
.79938 \\
.71418 \\
.36076\end{array}$ & $\begin{array}{r}472.59 \\
26.77 \\
9.65 \\
20.34\end{array}$ & $\begin{array}{l}<.000 \\
<.000 \\
0.003 \\
<.000\end{array}$ & \\
\hline
\end{tabular}

Bounds on condition number: $1: 294,10.749$

All variables left in the model are significant at the 0.1500 level.

No other variable met the 0.1500 significance level for entry into the model. 
The REG Procedure

Model: MODEL1

Dependent Variable: PV

Summary of Stepwise Selection

$\begin{array}{cl}\text { Step } & \text { Variab } \\ 1 & \text { Entere } \\ 2 & \text { tacid } \\ 3 & \text { mg2 }\end{array}$

Obs




1
1
1
1
1
1
1
1
1
20
21
22
23
24
25
2$$
\text { IFV PV }
$$

\section{Variable Removed}

\section{Number}

Partial

R-Square

Model

1
2
3

$\begin{array}{ll}0.4427 & 0.4427 \\ 0.1448 & 0.5875 \\ 0.0956 & 0.6831\end{array}$

0.0956

0.6831

$\mathrm{R}$-Square

$C(p)$

F value $\operatorname{Pr}>F$

23.2884

10.9254

$27.01<.0001$

The SAS System

$\begin{array}{lll}3.4406 & 9.65 & 0.0039\end{array}$

09:51 Friday, May 25, 2001

$a b$

$\operatorname{spg}$

$1 a$

sul

mg

m200 ratio

$\begin{array}{llll}40.00 & 24.90 & 15.10 & 0.790 \\ 43.30 & 25.00 & 18.30 & 2.390 \\ 41.80 & 27.30 & 14.50 & 2.640 \\ 46.90 & 35.30 & 11.60 & 6.250 \\ 44.00 & 27.70 & 16.30 & 2.020 \\ 42.70 & 26.80 & 15.90 & 1.560 \\ 44.00 & 28.80 & 15.20 & 3.050 \\ 44.60 & 28.70 & 15.90 & 2.380 \\ 44.80 & 31.00 & 13.80 & 1.210 \\ 45.90 & 31.30 & 14.60 & 3.760 \\ 46.20 & 30.00 & 16.20 & 2.020 \\ 47.60 & 31.30 & 16.30 & 2.740 \\ 43.50 & 32.70 & 10.80 & . \\ 46.70 & 32.00 & 14.70 & 4.000 \\ 40.50 & 24.10 & 16.40 & 1.030 \\ 40.10 & 23.60 & 16.50 & 1.860 \\ 41.30 & 24.90 & 16.40 & 1.000 \\ 43.60 & 28.40 & 15.20 & 2.480 \\ 41.60 & 28.00 & 13.60 & 1.590 \\ 41.90 & 28.10 & 13.80 & 2.950 \\ 38.60 & 28.14 & 10.46 & 2.170 \\ 40.20 & 24.72 & 15.48 & 1.780 \\ 44.38 & 22.69 & 21.69 & 2.000 \\ 43.14 & 23.49 & 19.65 & 1.030 \\ 39.48 & 21.67 & 17.81 & 0.930 \\ 43.00 & 20.87 & 22.13 & 1.350\end{array}$

\subsection{2}

25.530

0.36

.59928 .590

0.36

12.40

153.76

$1.70 \quad 1.23$

$0.48 \quad 2.56$

$9.57 \quad 11.3$

$\begin{array}{llll}9.86 & 11.30 & 127.69\end{array}$

$2.390 \quad 29.360$

$\begin{array}{llll}7.30 & 11.60 & 134.56\end{array}$

$2.24 \quad 12.40 \quad 153.76$$$
\begin{array}{ll}
4.79 & 12.90 \\
0.76 & 13.10
\end{array}
$$

$0.76 \quad 13.10$

$\begin{array}{ll}0.76 & 13.10 \\ 5.59 & 10.70\end{array}$

$\begin{array}{ll}5.59 & 10.70 \\ 3.29 & 12.60\end{array}$

$3.29 \quad 12.60 \quad 158.76$

2.24

11.90

2.632

24.750
29.500

13.18

10.10

$2.480 \quad 30.280$

2.56

0.55

$\begin{array}{ll}11.20 & 125.44 \\ 12.80 & 163.84\end{array}$

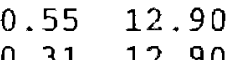

3.62

6.45

5.33

22.25

.

5.40

0.70

9.50

$2.586 \quad 27.000$

7.98

3. 60

2.20

$2.652 \quad 28.600$

10.92

0.60

$\begin{array}{ll}0.71 & 0.02\end{array}$

48.84

141.61

102.01

166.41

166.41

$3.13 \quad 2.07$

$2.11 \quad 0.11$

$9.82 \quad 3.55$

$5.29 \quad 1.79$

$1.34 \quad 0.21$

0.220 .03

$7.42 \quad 4.40$

$4.16 \quad 1.81$

$6.31 \quad 2.71$

$\begin{array}{ll}7.65 & 3.39\end{array}$

$\begin{array}{ll}5.56 & 0.78\end{array}$

$5.27 \quad 0.71$

$0.50 \quad 0.27$

$0.08 \quad 0.02$

$0.35 \quad 0.03$

$2.15 \quad 0.94$

$6.66 \quad 4.45$

$5.90 \quad 3.14$

29.16

2.72

$\begin{array}{rrr}0.49 & 5.76 \quad 3.64\end{array}$

$4.09 \quad 2.04$

12.96

4.84

$3.37 \quad 0.24$

$\begin{array}{ll}4.96 & 1.53\end{array}$

$\begin{array}{lll}0.36 & 1.97 & 0.15\end{array}$

. 69

$1.06 \quad 1.95$

$2.00 \quad 0.06$

$6.28 \quad 0.57$

$3.50 \quad 0.51$

0.19

$0.20 \quad 0.15$

3. 021.46

$2.35-0.77$

3.590 .75

$4.26 \quad 0.80$

$4.78 \quad 0.16$

$4.55 \quad 0.16$

$0.22 \quad 1.23$

$0.06 \quad 0.33$

0.320 .09

$1.21 \quad 0.78$

$2.21 \quad 2.01$

$2.76 \quad 1.14$

10.320 .23

2.121 .72

2.051 .00

3. 130.08

3.430 .45

1.820 .08 


$\begin{array}{rrrrrrrrrrrrrrrrrr}27 & 41.13 & 25.50 & 15.63 & 1.260 & 2.624 & . & 16.62 & 0.90 & 0.81 & 4.54 & 2.36 & 2.18 & 1.08 \\ 28 & 41.76 & 24.97 & 16.79 & 1.150 & 2.653 & 26.490 & 27.46 & 2.50 & 6.25 & 6.00 & 0.70 & 5.30 & 0.13 \\ 29 & 42.26 & 27.40 & 14.86 & 2.065 & 2.642 & 25.935 & 15.43 & 9.05 & 81.90 & 6.38 .0 .30 & 6.08 & 0.05 \\ 30 & 45.30 & 25.39 & 19.91 & 2.330 & 2.621 & 23.030 & 19.47 & 10.00 & 100.00 & 6.17 & 1.80 & 4.37 & 0.41 \\ 31 & 43.68 & 25.39 & 18.29 & 0.780 & 2.698 & 32.240 & 7.46 & 4.40 & 19.36 & 5.14 & 0.86 & 4.28 & 0.20 \\ 32 & 46.69 & 27.51 & 19.18 & 1.005 & 2.670 & 25.730 & . & 2.30 & 5.29 & 6.04 & 0.60 & 5.44 & 0.11 \\ 33 & 48.87 & 29.24 & 19.63 & 1.050 & 2.639 & 27.720 & . & 1.90 & 3.61 & 11.21 & 4.83 & 6.38 & 0.76 \\ 34 & 44.10 & 25.00 & 19.10 & 1.530 & 2.626 & 28.490 & 8.06 & 1.60 & 2.56 & 4.13 & 1.43 & 2.70 & 0.53 \\ 35 & 43.21 & 27.12 & 16.09 & 0.880 & 2.638 & 22.400 & . & 1.10 & 1.21 & 4.41 & 1.86 & 2.55 & 0.73 \\ 36 & 41.02 & 24.72 & 16.30 & . & . & . & . & 1.10 & 1.21 & 4.59 & 1.16 & 3.43 & 0.34 \\ 37 & 47.85 & 25.73 & 22.12 & 2.470 & 2.517 & 38.170 & 3.01 & 0.50 & 0.25 & 1.41 & 0.14 & 1.27 & 0.11 \\ 38 & 44.69 & 22.55 & 22.14 & 1.970 & 2.592 & 34.760 & . & 0.70 & 0.49 & 2.28 & 0.12 & 2.16 & 0.06 \\ 39 & 42.37 & 23.95 & 18.42 & 1.320 & 2.634 & 24.790 & 11.30 & 0.70 & 0.49 & 4.01 & 0.64 & 3.37 & 0.19 \\ 40 & 40.10 & 22.05 & 18.05 & 1.150 & 2.689 & 24.390 & . & 1.20 & 1.44 & 3.61 & 0.47 & 3.14 & 0.15 \\ 41 & 42.50 & 22.01 & 20.49 & 1.690 & 2.639 & 26.705 & 5.38 & 1.00 & 1.00 & 3.60 & 0.16 & 3.44 & 0.05\end{array}$


The SAS System

$13: 15$ Wednesday, June 21, 2000

Stepwise Procedure for Dependent Variable PV

Step 1 Variable AB Entered

DF

Regression
Error
Total

Variable

INTERCEP

$\mathrm{AB}$

Parameter
Estimate

22.49064418

2.01758941
$\mathrm{R}$-square $=0.44272690$

Sum of Squares

170.02372250

214.01375250

384.03747500

Standard

Error
0.84983969
0.38820347
Mean Square

170.02372250

6.29452213

Type II

Sum of Squares

4408.51710725

170.02372250
$C(p)=22.86726163$ 1 ,
F Prob $>$ F

$27.01 \quad 0.0001$

1 1

Bounds on condition number:

Step 2 Variable TACID Entered

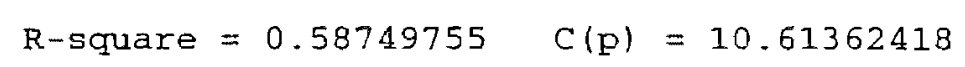

$R$-square $=0.58749755 \quad C(p)=10.61362418$

DF

$\begin{array}{lc}\text { Regression } & 2 \\ \text { Error } & 33 \\ \text { Total } & 35 \\ & \begin{array}{r}\text { Parameter } \\ \text { Estimate }\end{array} \\ \text { Variable } & \\ \text { INTERCEP } & 20.42283904 \\ \text { AB } & 2.12667074 \\ \text { TACID } & 0.42415378\end{array}$

Sum of Squares

$$
225.62107410
$$

158.41640090

384.03747500

Standard

Error

\begin{abstract}
0.95916404
0.34052860

0.12463482
\end{abstract}

Mean Square

112.81053705

4.80049700

Type II
Sum of Squares

2176.36961585

187.23176227

55.59735160
F $\quad$ Prob $>$ F

$23.50 \quad 0.0001$

$700.37 \quad 0.0001$

$27.01 \quad 0.0001$

Bounds on condition number:

1. 008939 ,

4.035756 
Step 3 Variable MG Entered

\begin{tabular}{lr} 
& \multicolumn{1}{c}{ DF } \\
Regression & 3 \\
Error & 32 \\
Total & 35 \\
& \\
Variable & Parameter \\
& Estimate \\
INTERCEP & 19.46590784 \\
AB & 1.72124710 \\
MG & 0.21049031 \\
TACID & 0.47863961
\end{tabular}

$\mathrm{R}$-square $=0.67498398$

$C(p)=$

4.00000000

Sum of Squares
259.21914296
124.81833204
384.03747500
Standard
Error
0.92403421
0.33660619
0.07171981
0.11387029

Mean Square

$\begin{array}{rr}F & \text { Prob>F } \\ 22.15 & 0.0001\end{array}$

86.40638099

3. 90057288

TYpe II

Sum of Squares
1731.01816500
101.99306429
33.59806886
68.91675437

$\begin{array}{rr}F & \text { PDUE>F } \\ 443.79 & 0.0001 \\ 26.15 & 0.0001 \\ 8.61 & 0.0061 \\ 17.67 & 0.0002\end{array}$

Bounds on condition number:

1. 246012 ,

10.48733

All variables left in the model are significant at the 0.15001 evel.

No other variable met the 0.1500 significance level for entry into the model.

Summary of Stepwise Procedure for Dependent Variable PV

\begin{tabular}{|c|c|c|c|c|c|c|c|}
\hline Step & $\begin{array}{l}\text { Variable } \\
\text { Entered Removed }\end{array}$ & $\begin{array}{r}\text { Number } \\
\text { In }\end{array}$ & $\begin{array}{r}\text { Partial } \\
R^{\star *} 2\end{array}$ & $\begin{array}{r}\text { Model } \\
R * \star 2\end{array}$ & $C(p)$ & $F$ & Prob>F \\
\hline 1 & $\mathrm{AB}$ & 1 & 0.4427 & 0.4427 & 22.8673 & 27.0114 & 0.0001 \\
\hline 2 & TACID & 2 & 0.1448 & 0.5875 & 10.6136 & 11.5816 & 0.0018 \\
\hline 3 & MG & 3 & 0.0875 & 0.6750 & 4.0000 & 8.6136 & 0.0061 \\
\hline
\end{tabular}

